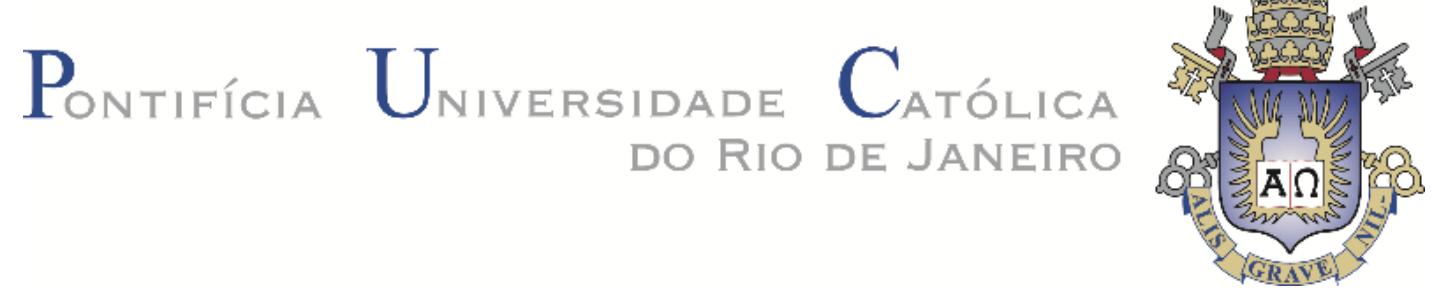

Marluce Souza de Andrade

\title{
O SINDICATO COMO ESPAÇO DE FORMAÇÃO: trajetórias de professores militantes do SEPE/Caxias
}

\section{Tese de Doutorado}

Tese apresentada ao Programa de Pós-graduação em Educação da PUC-Rio como requisito parcial para obtenção do grau de Doutor em Educação.

Orientadora: Prof ${ }^{\mathrm{a}}$. Isabel Alice Oswald Monteiro Lelis 


\section{Pontifícia Universidade Católica $_{\text {a }}$ \\ DO RIO DE JANEIRO}

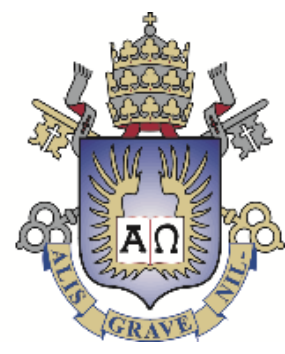

Marluce Souza de Andrade

"O sindicato como espaço de formação: trajetórias de professores militantes do SEPE/Caxias"

Tese apresentada como requisito parcial para obtenção do grau de Doutor pelo Programa de Pósgraduação em Educação do Departamento de Educação do Centro de Teologia e Ciências Humanas da PUC-Rio. Aprovada pela Comissão Examinadora abaixo assinada.

Profa. Isabel Alice Oswald Monteiro Lelis

Orientadora

Departamento de Educação - PUC-Rio

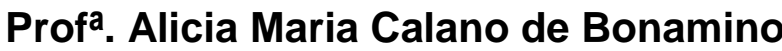
Departamento de Educação - PUC-RIO

Profa . Vera Maria Ferrão Candau Departamento de Educação - PUC-RIO

Prof ${ }^{a}$. Libânia Nacif Xavier Universidade Federal do Rio de Janeiro

Profa. Maria das Graças Chagas de Arruda Nascimento Universidade Federal do Rio de Janeiro

Profa. Monah winograd Coordenadora Setorial do Centro de Teologia e Ciências Humanas

PUC-Rio

Rio de Janeiro, 
Todos os direitos reservados. É proibida a reprodução total ou parcial do trabalho sem autorização do autor, do orientador e da universidade.

\section{Marluce Souza de Andrade}

Licenciada em pedagogia e mestre em Educação pela Pontifícia Universidade Católica do Rio de Janeiro. E especialista em docência do ensino superior pela Universidade Cândido Mendes. Membro do Grupo de Pesquisa sobre o Professor e o Ensino (Geppe) e integrante da Rede de Pesquisadores sobre Associativismo e Sindicalismo dos Trabalhadores da Educação. Áreas de pesquisa: trabalho, formação e sindicalismo docente. É professora das séries iniciais e orientadora pedagógica da rede municipal de Duque de Caxias.

Ficha Catalográfica

Andrade, Marluce Souza de

O sindicato como espaço de formação: trajetórias de professores militantes do SEPE/Caxias / Marluce Souza de Andrade; orientadora: Isabel Alice Oswald Monteiro Lelis. - 2017.

193 f.: il. color.; $30 \mathrm{~cm}$

Tese (doutorado) - Pontifícia Universidade Católica do Rio de Janeiro, Departamento de Educação, 2017.

Inclui bibliografia

1. Educação - Teses. 2. Formação. 3. Sindicalismo docente. 4. Sindicato. 5. Trajetórias de professores. 6. Duque de Caxias. I. Lelis, Isabel Alice Oswald Monteiro. II. Pontifícia Universidade Católica do Rio de Janeiro. Departamento de Educação. III. Título. 
Aos professores e professoras militantes do Sepe/Caxias. 


\section{Agradecimentos}

Agradeço primeiramente a Deus, que me deu vida, força e saúde para realizar essa jornada, e ao meu companheiro de todas as horas, Wellington, que tem me apoiado dia a dia ao longo dessa caminhada.

Agradeço especialmente a quatro instituições fundamentais para minha chegada até aqui: o Instituto de Educação Governador Roberto Silveira, onde entrei no préescolar e saí professora das séries iniciais; a todos os meus professores da educação básica; aos meus pais, pela escolha dessa escola, tão importante da minha trajetória; e a minha família ampliada que me apoiou durante todo percurso escolar e acadêmico.

À EDUCAFRO, especialmente ao Frei Davi, com sua rede de pré-vestibulares comunitários voltados à educação do afrodescendente e carente. Aos professores e coordenadores voluntários do "Pré-Centenário".

À Pontifícia Universidade Católica do Rio de Janeiro, aos funcionários do seu Departamento de Educação. Aos professores queridos que se foram, Leandro Konder, Ana Walleska, Marcelo Andrade e aos que estão chegando no departamento e já fazem parte de minha história, Silvana Mesquita e Jeferson Soares. Aos amigos que fiz na graduação, no mestrado, no GEPPE, e especialmente, à querida turma de 2014, com quem dividi as alegrias e anseios do doutorado. A ninguém mais que Isabel Lelis, minha grande incentivadora e parceira nesse processo de pesquisa e aprendizagem.

Ao Sindicato Estadual dos Profissionais da Educação do Rio de Janeiro, núcleo Duque de Caxias, grande inspiração para a realização desta pesquisa, pela luta em prol da dignidade no exercício da docência. Aos diretores, funcionários e a todos os militantes, pela abertura e acolhida à pesquisa.

À Capes, pela bolsa concedida durante a pesquisa.

Aos membros da banca e seus suplentes, Libânia Xavier, Vera Candau, Alicia Bonamino, Maria das Graças Nascimento, Márcia Ondina e Jeferson Soares, pela leitura atenta, pelas considerações e contribuições para o desenvolvimento do trabalho. 


\section{Resumo}

Andrade, Marluce Souza de; Lelis, Isabel Alice Oswald Monteiro. O sindicato como espaço de formação: trajetória de professores militantes do SEPE/Caxias. Rio de Janeiro, 2017. 193p. Tese de Doutorado Departamento de Educação, Pontifícia Universidade Católica do Rio de Janeiro.

Esta tese tem como objeto de estudo o sindicato enquanto instância de formação para o professor, procurando identificar as contribuições da participação sindical através de entrevistas sobre as trajetórias de vida de professores militantes, questionários aplicados aos membros da base e direção sindical em assembleias e observações dos fóruns ordinários e extraordinários promovidos pelo Sindicato dos Profissionais da Educação de Duque de Caxias (Sepe/Caxias). A escolha desse núcleo se deveu à sua história de 38 anos de lutas junto aos profissionais da educação da cidade. Foram entrevistados 15 professores de diferentes segmentos com mais de 5 anos de militância junto ao Sepe/Caxias, os quais relataram sua origem social, trajetória de formação, ingresso na docência e sua experiência sindical. Nos relatos, sobressaiu a origem humilde e pouco escolarizada e politizada das famílias desses sujeitos. A inserção deles na militância ocorreu via redes de sociabilidade, como grupos de jovens e participação nas comunidades eclesiais de base, onde os sujeitos são incentivados a "agir sobre o mundo". Além disso, a universidade, a associação de moradores e o partido político aparecem como pontes de aproximação com o sindicato. Mediante crescente atuação junto ao movimento sindical, os sujeitos relataram construir novos olhares para a docência e para a sociedade, contribuindo para a construção de uma identidade docente mais crítica. Os questionários evidenciaram as repercussões do envolvimento sindical nas relações que se estabelecem na escola, ora tendendo ao rechaço, ora ao prestígio, o professor militante vê sua trajetória profissional marcada também pela sua trajetória sindical. Ao adotar a observação da participação dos professores nas suas reuniões mensais de representantes de escola, assembleias, fóruns, atos e outros espaços promovidos pelo sindicato, a pesquisa pretendeu compreender a atuação desses sujeitos nesse 
contexto social, apreendendo a dimensão formativa dos diferentes espaços e tempos organizados por essa instituição. No cruzamento dos dados, foi possível identificar dois tipos de formação no âmbito sindical. Aquela que se dá no dia a dia das ações entre os pares e aquela que é previamente organizada em função de um objetivo. A primeira se trata de uma formação "político-sindical" que se dá pela participação nas reuniões, conselhos, assembleias, atos e demais ações promovidas pelo sindicato; está ligada ao conhecimento dos direitos, à interação com a sociedade e à conscientização enquanto categoria docente. Embora seja voltada à ação coletiva, esse tipo de formação é de difícil mensuração, visto que age sobre os conhecimentos e experiências pessoais de cada participante. Portanto, sua aprendizagem varia de acordo com suas disposições anteriores e intensidade de atuação no movimento sindical. O segundo tipo é uma formação "político-pedagógica", que segue um objetivo específico, quase sempre pedagógico ou funcional. Visa atender uma demanda imposta ao sindicato no contexto das lutas travadas pela melhoria das condições de exercício da docência. Para sua execução, recorre-se ao intercâmbio entre instituições, buscando a ajuda de especialistas acadêmicos. Por outro lado, aproveita-se também a experiência profissional dos membros do movimento sindical, tanto a acadêmica quanto a adquirida em outros espaços de militância. A tese aponta a importância dos sindicatos na formação dos professores, sobretudo em tempos de instabilidade democrática em que se acentua a precarização do magistério e avançam projetos de retirada de direitos e perda da autonomia docente.

\section{Palavras-chave}

Formação; Sindicalismo docente; Sindicato; Sepe; Duque de Caxias; Participação; Trajetórias de vida; Observação. 


\section{Abstract}

Andrade, Marluce Souza de; Lelis, Isabel Alice Oswald Monteiro (Advisor). Syndicate as a formative speace: militant teacher trajectories from SEPE/Caxias. Rio de Janeiro, 2017. 193p. Tese de Doutorado Departamento de Educação, Pontifícia Universidade Católica do Rio de Janeiro.

The purpose of this thesis is studying the syndicate as a training institution for teachers, seeking to identify the contributions of union participation to teaching through interviews on the life trajectories of militant teachers, questionnaires applied to members of the basis and the union leardership in assembly and observings of the ordinary and extraordinary forums promoted by the Union of Education Professionals of Duque de Caxias (Sepe/Caxias). The choice of this nucleus was due to its 38 - year history of struggles together with the education professionals at this city. Fifteen teachers from different school levels with more than 5 years of militant unionism were interviewed together with SEPE Caxias, which reported their social origins, formation trajectory, introduction in teaching and their union experience. In these reports the poor backgrounds, weekly schooled and less politicized families stood out. The introduction to militancy occurs through networks of sociability, as a young group and participation in the basic ecclesial communities, in which the subjects are encouraged to "act in the world". Universities, residents' associations and political parties also take important parts as bridges to approach with the union. Through a growing work with the syndical movement, the subjects report to create new perspectives for teaching and society, contributing to the construction of a more critical teaching identity. The questionnaires highlighted the repercussions of union involvement in the relations established at school, sometimes tending towards rejection, or prestige, the militant teacher sees the professional trajectory also marked by his/her union trajectory. The aim of this study was to understand the role of teachers in their monthly meetings of school representatives, assemblies, forums, acts and other spaces promoted by the union, and to understand their role in this social context, learning the formative dimension of different spaces and times organized by that institution. At the data cross-checking, it was possible to identify two types of syndical formation. The one that 
happens on the daily routine of actions among peers and the one that is previously organized aiming at a specific goal. The first is a "political-syndical" formation that happens through participation in the meetings, councils, assemblies, acts and other actions promoted by the union. It is linked to knowledge of rights, interaction with society and awareness as a teaching category. Although it is aimed at collective action, this type of training is difficult to measure, since it acts upon knowledge and personal experiences of each participant. Therefore, their leaning varies according to their previous provisions and intensity of action on the union movement. The second type is a "political-pedagogical" formation. It follows a specific goal, oftentimes pedagogical or functional. It aims to meet a demand imposed on the union connected to the struggle for improvement of teaching conditions. For its execution interchange among institutions was resorted, seeking the help of academic experts. On the other hand, professional experience, both academic and acquired in different areas of militancy, was also used. In conclusion, we point out the importance of the unions in the training of teachers, especially in times of democratic instability in which the precariousness of regency is accentuated; as well as projects of withdrawal of rights and loss of teacher autonomy tend to be more frequent.

\section{Keywords}

Training; Teacher syndicalism; Syndicate; Sepe; Duque de Caxias; Participation; Life trajectories; Observation. 


\section{Sumário}

1 INTRODUÇÃO

1.10 lugar de onde falo 15

1.2 Uma pesquisa qualitativa, seu objeto e ferramentas
metodológicas

1.3 Instrumentos de pesquisa 22

1.3.1 Leituras: força motriz da pesquisa 23

1.3.2 Questionários 32

1.3.3 Observações 35

1.3.4 Entrevistas sobre a trajetória de vida 38

1.4 Campo empírico 41

1.4.1 Duque de Caxias, um município da Baixada Fluminense 42

1.4.2 O Sepe e seu núcleo sindical em Duque de Caxias 44

2 OS SUJEITOS E SUAS HISTÓRIAS

2.1 Uma breve apresentação 48

2.2 A história dos encontros ou uma história de encontros 52

2.3 Trajetórias familiares 66

2.3.1 Origem, território e pertencimento social 66

2.3.2 Trabalho e escolarização 71

2.3.3 Valores familiares: gênero, religião e política 76

3 DO INGRESSO NA DOCÊNCIA À FORMAÇÃO NO ESPAÇO SINDICAL 85

3.1 "Escolha" pelo magistério e formação profissional 85

3.2 Formação superior no município de Duque de Caxias 101

3.3 Formação continuada 110

3.4 Formação no espaço sindical 113

4 TRAJETÓRIAS SINDICAIS

4.1 A chegada ao sindicato 121

4.2 Construção de uma história coletiva 133

4.3 Engajamento e atuação sindical 140

5 CONSIDERAÇÕES FINAIS 152

6 REFERÊNCIAS BIBLIOGRÁFICAS 159

$\begin{array}{ll}\text { ANEXOS } & 167\end{array}$

$\begin{array}{ll}\text { APÊNDICES } & 171\end{array}$ 


\section{Lista de llustrações}

\section{Figuras}

Figura 1 - Assembleia realizada no campus da FEBF em 08/04/2016

Figura 2 - Cartaz do curso preparatório para o concurso de Duque de Caxias 2015 108

Figura 3 - Cartaz da palestra "Base Nacional Comum Curricular" 109

Figura 4 - Níveis de engajamento sindical 146

\section{Quadros}

Quadro 1 - Categorias de análise da identidade 30

Quadro 2 - Informações básicas sobre os entrevistados 52

Quadro 3 - Síntese da formação "político-sindical" e

"político-pedagógica"

\section{Gráficos}

Gráfico 1 - Formação dos professores respondentes 102

Gráfico 2 - Filiação ao Sepe 142

Gráfico 3 - Sentimento de representatividade dos filiados em relação ao Sepe

Gráfico 4 - Participação no sindicato $\quad 144$

Gráfico 5 - Frequência às assembleias no período de data-base. 145

Gráfico 6 - Frequência no período de políticas de parcelamento salarial

Gráfico 7 - Interferência da participação sindical nas relações estabelecidas na escola 


\section{O Sindicato ${ }^{1}$}

Mas quem é o sindicato?

Ele fica sentado em sua casa com o telefone?

Seus pensamentos são secretos, suas decisões desconhecidas?

Quem é ele?

Você, eu, vocês, nós todos.

Ele veste a sua roupa, companheiro, e pensa com a sua cabeça.

Onde more é a casa dele, e quando você é atacado, ele luta.

Mostre-nos o caminho que devemos seguir e, nós seguiremos com você.

Mas não siga sem nós o caminho correto.

Ele é sem nós o mais errado.

Não se afaste de nós.

Podemos errar e você ter razão, portanto não se afaste de nós!

Que o caminho curto é melhor do que o longo, ninguém nega.

Mas quando alguém o conhece e não é capaz de mostrá-lo a nós, de que serve a sua sabedoria?

Seja sábio conosco!

Não se afaste de nós!

\footnotetext{
${ }^{1}$ Adaptado de "O partido", de Bertold Brecht, por Helder Molina.
} 


\section{1 \\ Introdução}

Um galo sozinho não tece uma manhã:

Ele precisará sempre de outros galos.

João Cabral de Melo Neto

Estudos sobre as organizações e ações coletivas dos profissionais da educação têm demonstrado a importância desses espaços para a construção histórica da profissão docente (Xavier, 2006; Vicentini \& Lugli, 2009). No entanto, há a necessidade de aprofundar o conhecimento sobre como são vividos esses espaços na atualidade.

Tendo em vista as transformações que a profissão docente vem sofrendo em função de reformas educacionais e mudanças sociais que afetam o status de "ser professor" nos dias hodiernos, assim como as reações de grupos de professores frente à perda crescente de direitos, aumento da pressão sobre o trabalho e declínio da autonomia docente, é importante ampliar o conhecimento sobre as organizações e ações coletivas dos profissionais da educação (Vianna, 2001).

Recentemente, alguns movimentos de professores chamaram a atenção da mídia e da opinião pública, como: o caso da agressão aos professores do Paraná, em 2015; a grande greve dos professores da Bahia, em 2013; a greve das universidades federais do Rio de Janeiro, em 2015; a greve unificada (município e Estado) no ano de 2013 no Rio de Janeiro. Esses e outros movimentos não podem ser ignorados, precisam ter suas pautas e fatores desencadeadores analisados para se pensar no atual quadro do magistério no Brasil e sua mobilização frente a ele.

Portanto, pensando em todas essas transformações sociais e na capacidade de mobilização docente frente ao crescente processo de desprofissionalização, esta pesquisa toma como objeto a influência do sindicalismo na formação do docente. O interesse por esse tema nasce em meio às discussões do Grupo de Pesquisas sobre o Professor e o Ensino (Geppe) a respeito dos conceitos profissionalização/desprofissionalização, trazidos a partir do programa de estudos de pós-doutorado da coordenadora, Isabel Lelis.

O que a pesquisa pretendeu, ao adotar a observação da participação dos professores nas suas reuniões mensais de representantes de escola, assembleias, fóruns, atos e outros espaços promovidos pelo sindicato, foi compreender sua 
atuação nesse contexto social, apreendendo a dimensão formativa dos diferentes espaços e tempos organizados pelo movimento sindical. Por meio das entrevistas, procuramos encontrar os sentidos dessa formação para os sujeitos, entendendo que a experiência sindical assume um significado individual e também coletivo na trajetória de vida dos professores que dela participam.

O interesse pessoal nessa temática se refere ao meu desenvolvimento profissional ao longo de 15 anos de trabalho em diferentes escolas e creches da rede pública municipal de ensino de Duque de Caxias, a qual é fortemente marcada pela ação do Sindicato Estadual dos Profissionais da Educação, núcleo Duque de Caxias (Sepe/Caxias).

A ideia inicial foi investigar a associação de professores ao movimento sindical, buscando as principais razões da filiação, o nível de militância e a possível influência dessa prática no trabalho docente e nas relações que se estabelecem na escola. Diante de uma literatura que apontava para a complexidade do trabalho docente (Tardif \& Lessard 2008; Lantheaume 2012), o isolamento profissional e a desprofissionalização do professor (Demailly, 2013), busquei olhar para a associação sindical como uma possibilidade de pensar construção da identidade profissional do professor.

Iniciei meu percurso com um levantamento das produções sobre sindicalismo docente no Brasil entre os anos 2000 e 2015. Chegando a um quantitativo de 18 artigos, 8 dissertações e 3 teses. Após a leitura e análise dessa produção ${ }^{2}$, ficou perceptível que a recente produção acadêmica sobre sindicalismo docente é pequena e se ocupa, em geral, com a constituição histórica e política da ação sindical de maneira a se voltar para os sindicatos enquanto organizações. Apenas alguns desses trabalhos se debruçam sobre as experiências dos indivíduos nesse contexto.

A partir dessa análise, buscando contribuir para ampliação do conhecimento no campo de pesquisa sobre sindicalismo docente, optei por estudar o sindicato por dentro, observando e dialogando com os sujeitos que dele fazem parte cotidianamente. Dessa forma, entre julho de 2015 e julho de 2017 realizei observações diretas no movimento sindical em Duque de Caxias, apliquei um questionário sobre a atuação e formação dos participantes, assim como fiz um

\footnotetext{
${ }^{2}$ Quanto às teses e dissertações, foi feita uma leitura inicial dos resumos para selecionar os trabalhos que seriam lidos integralmente.
} 
conjunto de entrevistas com dirigentes sindicais e membros da base ${ }^{3}$ deste sindicato.

Após esse levantamento de dados em dois anos de campo de pesquisa, iniciar a escrita da tese foi tarefa difícil, pois implicou em revisitar os primeiros passos, rever análises iniciais, fazer seleção de informações e deixar alguns dados para trás em nome de um olhar mais aprofundado a determinados aspectos observados.

Assim, nesse primeiro capítulo, para contextualizar o percurso de construção da pesquisa, trago um pouco de minha história, o lugar de onde falo e as questões que me movem; a descrição do objeto e o contexto que o delineia; além dos percursos e ferramentas utilizadas na pesquisa.

\section{1 \\ O lugar de onde falo}

Por que iniciar a tese contando um pouco de minha história? Pela certeza de que os caminhos por onde passei e pelos valores e conhecimentos que construí ao longo da vida estão presentes neste trabalho.

Vários autores alertam para as questões que envolvem a objetividade e subjetividade do pesquisador durante o processo de pesquisa (Van Zanten, 2004a, 2004b; Tura, 2011; Velho, 1980). De acordo com Lelis (1996, p. 12), a relação com o objeto de pesquisa sempre é atravessada por questões de cunho sentimental:

Mantemos com o nosso objeto uma relação afetiva que é preciso assinalar para que não resvalemos para uma objetividade que é impossível de ser garantida. A distância existe enquanto necessidade e critério para operarmos com algum rigor que não se confunde com rigidez como advoga Bourdieu.

Seguindo esse conselho, é válido relatar alguns aspectos de minha trajetória dentro do sindicato, destacando minha atuação como professora da rede municipal de Duque de Caxias, e membro do conselho de representantes de escolas no Sepe/Caxias. A participação nesse espaço, concomitantemente às reflexões junto ao Geppe, suscitaram em mim as seguintes questões: que contribuições o espaço

\footnotetext{
${ }^{3}$ Base é o conjunto de sujeitos representados por determinado sindicato. No caso do SEPE, são os profissionais da educação que atuam nas escolas públicas estaduais e municipais do Estado do Rio de Janeiro.
} 
sindical traria ao professor na atualidade? Seria esse um espaço formativo? Em que aspectos? Como e em quais âmbitos se daria essa formação?

Oriunda dos pré-vestibulares comunitários da Rede Educafro (Educação para o Afrodescendente Carente) que é ligada à igreja católica, fui aluna bolsista da PUC desde 2002, quando cursei pedagogia ao mesmo tempo em que trabalhava como professora na rede municipal de Duque de Caxias. Assim, desenvolvi o interesse pela temática da relação entre desigualdade social e a educação. No mestrado (2010-2012), busquei compreender como famílias de camadas menos favorecidas escolhiam uma escola pública ou privada para seus filhos, investigando as concepções de qualidade desenvolvidas por essas famílias.

Desde 2010, frequento o Geppe, e nesses encontros nasceu em mim o desejo de voltar-me à temática do professor. Portanto, continuei a pesquisar a questão da escolha de escola, mas por pais professores. Com esse projeto, entrei no doutorado e permaneci até o segundo ano do curso.

Em meados de 2015, após intensificar minha atuação no movimento sindical e passar por uma experiência marcante junto a este, percebi que havia ali um importante campo de pesquisa sobre o professor. A participação foi crescente à medida que fui me envolvendo cada vez mais nas lutas travadas no Sepe/Caxias. Assim foi crescendo também o interesse em pesquisar esse espaço, voltando-me por completo para o estudo do professor e sua experiência no âmbito sindical.

Logo que desejei fazer a mudança de temática de pesquisa encontrei a abertura e apoio necessários para a construção desse novo objeto, tanto da parte de minha orientadora, quanto do próprio campo onde seria realizada a pesquisa, o Sepe/Caxias.

Rapidamente me aproximei do campo e isso trouxe implicações na realização da pesquisa e também na minha vida profissional e pessoal. Junto com a ampliação do conhecimento sobre pesquisa em educação - objetivo do curso de doutorado vivi novas experiências e ampliei meu capital social. Hoje sou uma professora diferente, com outros repertórios e novos modos de olhar os profissionais da educação, a escola e a sociedade. É preciso ressaltar que em minha trajetória pessoal o sindicato contribuiu significativamente na formação política e prática pedagógica.

Moradora de Duque de Caxias, desde que nasci, fui normalista na rede estadual de ensino, onde estabeleci os primeiros contatos com o Sepe por meio de alguns dos meus professores. Recém-formada, prestei concurso para a prefeitura de 
Duque de Caxias e logo me filiei ao sindicato. No entanto, minha participação inicial era restrita a movimentos de "data-base" ${ }^{4}$ e presença em assembleias. Com o passar do tempo, fui me aproximando mais de outras atividades desenvolvidas no núcleo, como seminários e debates.

Assim, professora da rede pública municipal de Duque de Caxias, sindicalizada desde o primeiro ano de ingresso nessa rede, nutri crescente admiração pelo núcleo do Sepe nesse município. Sua atuação junto aos professores, orientando e incentivando o envolvimento na política educacional chamavam a atenção ao contrastar com o sentimento de apatia e passividade que circunda o magistério nos últimos tempos.

Em seu artigo "O triângulo da formação docente: seus jogadores e configurações", Sarti (2012) é bastante contundente ao afirmar que o professor vem ocupando o lugar de "morto" no jogo da formação docente. Vitimado por condições precárias de formação e trabalho, o professor tem sido o "morto" também no âmbito da ação política. Hoje, o sindicato representa um dos poucos espaços onde a voz do professor ainda se faz ecoar. Ali, entre pares, existe a possibilidade de o professor somar forças para agir coletivamente a favor das condições necessárias para o exercício do seu ofício e para participação das discussões a respeito das políticas educacionais.

Ainda assim, não podemos idealizar esse espaço. O sindicato é um campo de lutas, no sentido em que nos coloca Bourdieu. Há constantes disputas pelo domínio do campo e trocas de posições entre seus membros. E, por isso mesmo, é necessário explicitar meu lugar dentro desse campo, não no sentido de reforçar estereótipos, mas de mostrar o lugar de onde falo para fugir da falsa aparência de neutralidade, "pois a realidade é sempre filtrada por um determinado ponto de vista" e com isso não se pretende "proclamar a falência do rigor científico" e sim, "a necessidade de percebê-lo enquanto objetividade relativa, mais ou menos ideológica e sempre interpretativa." (Velho, 1978, p. 9).

Em 2010, assumi uma nova matrícula na rede municipal de Duque de Caxias, como professora da educação infantil em uma creche do $1^{\circ}$ Distrito ${ }^{5}$. Nessa unidade, situada em uma comunidade violenta da cidade - hoje "pacificada" - vivenciei,

\footnotetext{
${ }^{4}$ Período estipulado por lei para discussão sobre o reajuste anual.

${ }^{5} \mathrm{O}$ município é subdividido em quatro distritos: Centro, Campos Elísios, Imbariê e Xerém. Ver o mapa de Duque de Caxias no Anexo A.
} 
durante a greve, o autoritarismo por parte da direção, após ter ido dialogar com os pais dos meus alunos sobre a falta de condições estruturais da unidade escolar. Sentindo-me ameaçada, devido ao contexto da situação, acionei o sindicato que me deu total apoio diante da Secretaria de Educação para que eu pudesse escolher uma nova escola mesmo estando em estágio probatório. Foi então que me aproximei mais do sindicato, pois a partir desse episódio, senti-me amparada por uma rede de proteção que ultrapassava a fragilidade do isolamento do professor na unidade escolar. Passei a compreender o lema: "unidos somos mais fortes", tantas vezes repetido nas assembleias.

Após mudar para a Creche e Pré-escola Municipal Prof ${ }^{a}$. Armanda Álvaro Alberto, tornei-me suplente da representante da escola no sindicato. Alternávamos a participação conforme a disponibilidade, já que ambas possuíamos duas matrículas na rede e fazíamos pós-graduação, sendo difícil estar presente em todas as ocasiões. Inicialmente, minha participação se restringia a levar as decisões do conselho de representantes para a escola, que em algumas ocasiões não aderia às propostas; depois passei a apresentar o panorama da minha unidade no conselho até que conseguimos estabelecer com o grupo um clima de cooperação e formulação de propostas próprias.

Em 2014, houve uma greve bastante intensa em nossa rede de ensino. Eu já estava completamente envolvida com o movimento sindical, "corria escolas" do $3^{\circ}$ Distrito, em busca de dialogar sobre as pautas e convencer os colegas de outras unidades a aderirem ao movimento grevista. Ao final da greve, tornei-me membro da comissão para discussão da implementação do "1/3 de hora atividade", como representante dos professores de educação infantil e educação de jovens e adultos (EJA), já que, naquele momento, eu acumulava as duas funções na rede.

O 1/3 de atividades sem interação com aluno, mais conhecido como " $1 / 3$ de planejamento" foi garantido pela Lei do Piso Salarial, n 11.738 de 2008. Em 2014, ainda não havia sido implementado pelo município, portanto, um direito negado. Esse foi um dos pontos de reivindicação mais importantes da pauta nesse ano, juntamente com eleições para diretor e o concurso público. Sem essa tríade ampliava-se a cada ano a precarização do trabalho do professor na rede municipal de Duque de Caxias. Ao fim da greve, um dos acordos da negociação foi instaurar uma comissão paritária entre membros da Secretaria de Educação e o Sepe. Da parte 
que cabia ao sindicato, tentou-se distribuir a representação por segmento, direção do sindicato, professores especialistas, creche e EJA.

No interior do sindicato, fez-se uma plenária aberta a todos os filiados para estabelecer uma proposta de implementação da lei $n^{\circ} 11.728 / 2008$, a qual foi apresentada à SME para apreciação. Um ano de reuniões, entre encontros e desmarcações por parte do governo, e a prefeitura se negava a apresentar sua proposta para a categoria e sequer dava um posicionamento sobre a proposta apresentada pelo sindicato. Os encontros eram desgastantes, o tempo inteiro a Secretaria de Educação, na pessoa da subsecretária de ensino, ex-sindicalista, dizia não ter condições de apresentar algo em função da falta de professores na rede - 10 anos haviam se passado sem que houvesse concurso público. Ao final do ano, a comissão saiu bastante frustrada pelo tempo empreendido sem o resultado esperado. Acompanhei todo esse embate extenuante, refletindo sobre o lugar que o professor e o ensino ocupam hoje na ótica do governo e sobre a capacidade de organização dos docentes frente a toda essa desvalorização.

Hoje, como orientadora pedagógica em outra escola da rede municipal de Duque de Caxias, atuo novamente como representante no conselho junto ao sindicato. Essa "função" tem sido importante no processo de pesquisa, pois não sou apenas uma observadora externa, sou uma participante real, representando a minha escola no sindicato.

Assim, a minha trajetória dentro do sindicato vem sendo considerada ao longo da pesquisa, sobretudo na realização das observações e entrevistas. O exercício do "estranhamento" do familiar é um esforço constante para a realização da pesquisa. Para Velho (1978, p. 131), “O processo de estranhar o familiar tornase possível quando somos capazes de confrontar intelectualmente, e mesmo emocionalmente, diferentes versões e interpretações existentes a respeito de fatos, situações."

Para o autor, pesquisar a própria sociedade significa enfrentar os limites e marcas advindas do pertencimento a uma cultura, classe ou grupo social. "É uma tarefa assumida com todos os riscos e desgastes que envolve.” (Velho, 1980, p. 20).

No decorrer da pesquisa, inúmeras vezes as identidades de pesquisadora, professora, orientadora, representante e militante se atravessaram, sendo necessário a busca do equilíbrio para não ultrapassar os limites de cada campo de atuação e, ao mesmo tempo, não adotar posturas incoerentes ou falsamente neutras. 
Nesse caminho, em algumas ocasiões foi necessário priorizar o ouvir, atentando para questões que a princípio poderiam parecer óbvias ou sem importância alguma. Foi preciso rever valores, práticas cotidianas do movimento sindical que até então passavam despercebidas. Tive que fazer um grande esforço para empreender um novo olhar para o habitual.

Por outro lado, minha história de participação no sindicato favoreceu a entrada no campo e minimizou os possíveis incômodos dos sujeitos da pesquisa ao serem observados. Também permitiu uma maior abertura do campo no que diz respeito à concessão de entrevistas e acesso às diferentes instâncias sindicais, da direção à base.

Nesse percurso, que é acadêmico, mas também humano, estabeleci novas amizades que me aproximaram ainda mais do movimento sindical e dos seus participantes. Esse novo círculo, que obviamente não foi concebido como uma estratégia para a realização da pesquisa, acabou contribuindo para esta, ao mesmo tempo em que intensificou o desafio do estranhamento pela proximidade com uma das diversas tendências de pensamento dentro do universo sindical.

Outra questão a ressaltar, é o exercício profissional do magistério em uma rede que historicamente não oferece condições adequadas de trabalho e, mais recentemente, tem sido influenciada pelo quadro nacional de "crise", apresentando um cenário de atrasos salariais e redução dos direitos assegurados no plano de carreira. Como membro da camada popular, que sempre necessitou conciliar trabalho e estudo, essas questões materiais também repercutiram nas escolhas e caminhos adotados na pesquisa.

Assim, todos esses meus percursos - acadêmico, profissional e sindical estão presentes na pesquisa, da escolha do tema à sua execução. Relato mais detalhadamente esse processo de construção do objeto, escolha dos instrumentos metodológicos e a chegada ao campo nas seções seguintes.

\section{2}

\section{Uma pesquisa qualitativa, seu objeto e ferramentas metodológicas}

Diante das críticas às Ciências Sociais, questionando seu status de ciência, Phillipis \& Burbules (2000) ressaltam a importância de se explicitar o lugar de onde 
se está falando. Ou seja, deixar claro o paradigma de ciência adotado, o que se entende por pesquisa em Ciências Sociais, mais especificamente em educação.

Em se tratando de Ciências Sociais e Humanas, deparamo-nos com a impossibilidade de eleger uma verdade diante dos diferentes olhares sobre o mesmo fato. Isso não significa abrir mão da confiabilidade, pelo contrário, ela deve ser garantida pela escolha adequada do método à questão proposta, bem como em sua competente aplicação para que se possam fornecer determinadas "garantias" às conclusões.

$\mathrm{Na}$ tentativa de garantir tal confiabilidade, apresentamos aqui as opções teóricas sob as quais decidimos nos pautar, as questões-guia do trabalho, os métodos utilizados no decorrer da pesquisa, bem como as razões que nos lavaram a optar por eles.

Estamos tratando de uma pesquisa de natureza qualitativa, cujos referenciais teóricos metodológicos se situam no campo da pesquisa sobre o trabalho e sindicalismo docente. Embora o objeto traga em si um caráter sociológico, também contribuíram para a pesquisa, sobretudo no aspecto metodológico, os estudos do campo da antropologia e da história da educação.

O olhar sobre o movimento sindical está direcionado para as influências do pertencimento a essa organização política. Portanto, a questão base que guia o trabalho é o aspecto formativo do espaço sindical, que se desdobra nas seguintes perguntas: Como o sindicato contribui para o crescimento do professor? Que marcas identitárias esse espaço de socialização deixa em seus participantes? Como as experiências individuais e coletivas vividas no movimento sindical refletem sobre a trajetória dos professores?

Para Phillips \& Burbules (2000), a pesquisa é sempre uma interpretação da realidade, mas há critérios sobre os quais devemos embasar nossa interpretação aqui utilizada. Portanto, é fundamental explicitar o caminho metodológico que me fez chegar até ela. Embora não haja única verdade pronta e acabada, as recorrências no campo nos aproximam de explicações verossímeis. As pistas que o campo traz devem ser coletadas e examinadas com o máximo de atenção, pois podem ajudar a construir explicações e respaldar as conclusões sobre a pesquisa.

Para Van Zanten (2004b), é importante sermos rigorosos porque nossas provas empíricas não constituem nunca totalmente uma prova, mas permitem, pelo menos, uma transparência na discussão: 
Se um pesquisador nos mostra o material que dispõe, o que selecionou, o que montou, há um debate possível entre os atores e é possível que digamos que interpretamos diferentemente dele. Isto permite a transparência e um tipo de discussão dos resultados. (p. 35).

Para a autora, a validade do conhecimento científico tem também relação com o fato desta produção ser cumulativa. A nossa produção é científica justamente porque se inscreve em um campo de produção científica. Mesmo quando se trata de um estudo pequeno, microssociológico, localizado, ele se inscreve em um campo muito mais amplo e a sua validade diz respeito à contribuição que oferece a um conhecimento já existente.

No caso desta tese, debruço-me sobre um dos 48 núcleos que compõem o Sindicato Estadual dos Profissionais da Educação (Sepe). A escolha dessa unidade se deu pela sua importância histórica e participação atual nas lutas sindicais que envolvem os docentes de todo o Brasil. A escolha também foi feita pela vinculação pessoal, já explicitada anteriormente.

Sobre a possibilidade de generalização, Van Zanten (2004b) alerta sobre os riscos de se render à tentação de não generalizar ou generalizar demasiadamente os resultados. A autora propõe uma "generalização de médio alcance", a qual é possível pela aproximação do trabalho microssociológico com outros trabalhos desenvolvidos no mesmo campo.

Esses autores trazem em comum a reflexão de que embora não haja uma verdade absoluta a ser descoberta no campo da educação é possível fazer ciência nessa área através de um trabalho comprometido com o rigor científico. $\mathrm{O}$ pesquisador necessita submeter sua pesquisa a técnicas metodológicas que o conduza a resultados confiáveis, ainda que estes sejam refutáveis e provisórios. Nesse sentido, apresento a seguir as opções metodológicas as quais recorri ao longo da pesquisa.

\section{3}

Instrumentos de pesquisa

Nessa seção, são detalhados os caminhos metodológicos percorridos ao longo desta pesquisa sobre a formação docente no meio sindical. Tais caminhos não são lineares. Foi necessário interromper percursos e abrir novas estradas em busca de 
melhores pontos de observação sem, contudo, perder o horizonte, que é a contribuição do sindicato na formação profissional e política dos professores.

Nessa empreitada, alguns instrumentos apresentados ao longo do curso de Pós-Graduação em Educação da PUC-Rio foram valiosos, contribuindo para esta pesquisa. De uma perspectiva mais ampla a mais focada, levantamento bibliográfico, observações, questionários e entrevistas foram utilizados para a construção dos dados da pesquisa, conforme apresento a seguir.

\subsection{1}

Leituras: força motriz da pesquisa

Ler para descobrir e constituir instrumentos de trabalho.

Kaufmann

Ao iniciar a escrita do projeto, percebi a necessidade de buscar um aprofundamento acerca do campo de estudos sobre associativismo e sindicalismo docente. Para tanto, realizei um levantamento bibliográfico nos principais veículos de pesquisa disponíveis virtualmente: a Scientific Eletronic Libray Online (SciELO) e o banco de dados da Coordenação de Aperfeiçoamento de Pessoal de Nível Superior (Capes).

$\mathrm{Na}$ pesquisa dos artigos disponibilizados pela SciELO Brasil (2001-2015), enfocando a questão do sindicalismo, encontrei 18 trabalhos que tratam do assunto. Escolhi os seguintes descritores para essa pesquisa: "sindicalismo docente" e "associativismo docente". Os artigos foram lidos na íntegra, fichados e analisados em suas potenciais contribuições para esta pesquisa.

No banco de dados da Capes, com os mesmos descritores da pesquisa mencionada acima, foram encontradas 8 dissertações e 3 teses, produzidas no âmbito de diferentes áreas do conhecimento: educação, história, sociologia e política, demonstrando as diversas possibilidades de abordagem dentro da temática.

As leituras iniciais foram fundamentais para ter um panorama do que vem sendo produzido no campo e ajudar na delimitação do objeto. Segundo Kaufmann (2013, p. 63), dois tipos de leitura são necessários em uma pesquisa: o primeiro tem o objetivo de fazer um "levantamento do estado do conhecimento a respeito do tema tratado" e o segundo objetiva a "problematização". 
Desses dois tipos de leitura, destaco algumas obras nas quais me apoiei para delimitação do objeto e sua problematização. Do primeiro tipo de leitura citada por Kaufmann (2013), a obra de Claudia Vianna $(1999,2010)$ trouxe um quadro sobre os estudos do sindicalismo docente. Em sua tese, posteriormente transformada em livro e artigo, a autora faz um aprofundado levantamento e análise das produções a respeito do sindicalismo docente nas décadas 1980 e 1990.

O levantamento bibliográfico feito por Vianna (1999), em que pesem as transformações ocorridas no magistério e, por conseguinte, na organização sindical, tem grande importância para o estudo da temática. São 47 dissertações e 7 teses subdivididas em dois blocos temáticos: "a organização docente sob a ótica da consciência política e do pertencimento de classe" e a "organização docente sob a ótica da crise".

Do primeiro bloco temático, "a organização docente sob a ótica da consciência política e do pertencimento de classe", é válido destacar a formação política do professorado que se envolve na luta sindical e o desenvolvimento do sentimento de identificação e pertencimento de classe. Nesse conjunto de trabalhos há ênfase na capacidade de "transformação da escola e da sociedade por meio da organização docente".

Vianna (2001) alerta que, dado o contexto histórico, as primeiras produções sobre a temática tinham caráter eufórico de otimismo, mas apresentam análises fragmentadas da organização docente, "mostrando apenas uma de suas faces: a força e o poder do engajamento coletivo" (p. 105).

De acordo com a autora, "o processo de constituição da imagem professortrabalhador foi amplamente mencionado por essa bibliografia, a partir da ideia de ruptura entre esse modelo e o de professor-sacerdote." Contudo, Vianna (2001, p. 107) questiona a análise do processo de organização docente com base em uma ruptura entre essas duas imagens, pois considera ser "mais fértil a ideia de tensão constante entre permanências e mudanças do que a noção de ruptura."

O segundo grupo de trabalhos, se foca no resgate da história e no sindicalismo como única forma de representação. A principal distinção entre os trabalhos do primeiro e do segundo bloco é a ruptura com o otimismo do momento anterior e a introdução da ideia de crise. Vianna (2001) encontra nesses trabalhos os seguintes indicadores da crise da organização sindical docente: 1) esgotamento das greves; 2) ausência de diálogo com a população usuária das escolas públicas; 3) divergências 
político-ideológicas nas entidades; 4) distância entre as lideranças das associações/sindicatos e o professorado.

Para a autora, não são apenas as condições objetivas que favorecem ou fazem declinar a organização do professorado. "Vale investigar o campo da ação como resultado da interseção entre orientações externas e internas do ator." (Vianna, 2001, p. 121).

Seguindo essa linha, há ainda uma importante fonte de pesquisa sobre o sindicalismo/associativismo docente a ser mencionada. Trata-se do trabalho de Libânia Xavier (2013) sobre associativismo docente e construção democrática no Brasil e em Portugal, no qual a autora analisa diferentes trajetórias profissionais de professores ligados à militância política na busca pela democratização do ensino e da sociedade entre as décadas de 1950 e 1980.

No livro “Associativismo docente e construção democrática”, Xavier (2013) trata da profissão docente no Brasil e em Portugal pela via da temática do associativismo e do processo de democratização após intenso período de uma política autoritária em ambos os países. Para a autora, "a participação em movimentos e ações coletivas, assim como em associações de caráter político e sindical, é parte de uma experiência que contribui para a redefinição e a constituição de novas identidades, no âmbito pessoal, profissional, político e social.” (p. 199).

Entre as contribuições que a autora nos traz para o estudo da organização docente, destacamos a reunião de depoimentos sobre as trajetórias individuais de professores que vivenciaram o contexto de luta sindical durante a histórica transição democrática dos anos 1970-80. A ampliação das bases de sustentação política; crescimento do coletivo de professores; compromisso com a escola pública; o sindicato como espaço de sociabilidades; influência da participação sindical nas opções políticas, acadêmicas e profissionais foram alguns dos aspectos abordados.

Segundo a autora, vários entrevistados ressaltaram o aprendizado proporcionado pela "experiência associativa [...] demonstrando que um dos impactos da participação em associações coletivas tem relação com a formação de atitudes propositivas diante dos problemas laborais e instrucionais, assim como diante da realidade política e social.” (Xavier, 2013, p. 200).

O conjunto de depoimentos, marcados pela vivência em um contexto histórico de repressão e, portanto, de grande ânsia pela democracia nos ajuda a pensar questões peculiares ao momento político atual em que vivenciamos o 
desmoronamento de alguns valores democráticos construídos com a participação daqueles agentes.

Outra abordagem interessante dessa obra é o destaque à cobertura jornalística em um contexto de ascensão dos movimentos sociais de oposição ao regime ditatorial e redemocratização política no Brasil. Analisando as notícias, a autora mostra tanto estratégias de manipulação da opinião pública pelo discurso da imprensa, quanto a utilização por parte das entidades sindicais da visibilidade propiciada pela cobertura da mídia em prol de suas pautas.

Xavier (2013) destaca as representações da imprensa ao noticiarem informações e opiniões sobre as grandes greves de 1979 e 1988, entrando nas "questões de saber-poder de manipulação das identidades, numa disputa em torno da força simbólica que estas exercem sobre a opinião pública e sobre os próprios profissionais.” (p. 126). Esse viés vai ao encontro do que propõe Dubar (2005) sobre a dualidade da construção das identidades sociais na ligação do processo relacional, de "identidade para o outro" ao processo biográfico, "de identidade para si”.

A partir desse trabalho, cabe a esta pesquisa articular as questões levantadas na história do associativismo e na trajetória dos sujeitos que vivenciaram o sindicalismo no período de redemocratização às questões que emergem atualmente no contínuo processo de construção da profissão docente.

A despeito da importância desses dois importantes trabalhos sobre a organização docente, que forneceram pistas para a realização desta pesquisa, é válido ressaltar que ambos abordam um período anterior às reformas educacionais dos anos 1990, as quais vêm se intensificando na atualidade. Essas reformas têm um importante impacto no ofício e identidade docente e, por conseguinte, influenciam o movimento sindical. Portanto, sem ignorar as contribuições de Vianna (1999, 2001) e Xavier (2013), foi necessário buscar outros trabalhos que abarcassem questões que emergiram em um contexto mais recente.

Assim, ao panorama da organização docente apresentado por Vianna e o quadro do associativismo em contexto de redemocratização analisado por Xavier, foram agregados estudos, como um dossiê temático produzido pelo periódico "Educar em Revista" e parte da produção da Rede de Pesquisadores sobre Associativismo e Sindicalismo dos Trabalhadores em Educação (Rede Aste). 
O dossiê "Sindicalismo docente: experiências, limites, desafios e perspectivas", foi publicado em 2013, com 8 artigos sobre a questão do associativismo doente na atualidade. Alguns desses autores compõem a Rede Aste, criada em 2009 a fim de reunir a produção de pesquisas sobre essa temática ${ }^{6}$.

A Rede Aste vem construindo uma biblioteca chamada "Sindicalismo em Educação", já em seu $3^{\circ}$ volume. Trata-se de uma coletânea de artigos produzidos por pesquisadores da temática em diferentes estados do Brasil, países da América Latina e Europa. Diante da baixa produção percebida no levantamento inicial sobre a temática, encontrar essa rede de pesquisadores foi muito importante, e trouxe novo ânimo ao desenvolvimento da pesquisa.

Entre a produção da Rede Aste, destaco as contribuições de Márcia Ondina Vieira Ferreira, que desenvolve pesquisas no campo do gênero e sindicalismo docente, aprofundando-se em questões como representação e identidade no âmbito sindical.

Em "Somos todos trabalhadores em educação? Reflexões sobre identidades docentes desde a perspectiva de sindicalistas", Ferreira (2006) suscita o debate em torno da identidade, analisando os argumentos utilizados pelo professorado para explicar sua situação e entender os motivos da sindicalização docente. A autora entende que esse procedimento metodológico ajuda a conhecer como as pessoas constroem suas identidades e quais representações a respeito do trabalho docente circulam nos âmbitos escolares, pois para ela: "tanto as representações, quanto as identidades, não são fixas e sim produzidas e reproduzidas cotidianamente, não sendo inerentes aos indivíduos.” (Ferreira, 2006, p. 227).

Em "Notas sobre as relações entre identidade e sindicalismo docentes", Ferreira (2007) explora a possibilidade de unir os temas "identidade" e "sindicalismo docente". A autora apresenta uma série de trabalhos sobre sindicalismo na América Latina, mostrando algumas diferenças entre os países que a compõe, demonstrando como são vastas as produções na área, e quão diversas são as possibilidades de pesquisa dentro dessa temática. Sugere também que se

\footnotetext{
${ }^{6}$ Atualmente integro essa rede de pesquisadores. Fiz uma comunicação sobre os dados parciais da presente pesquisa no encontro realizado em São Paulo, na Uninove, em novembro de 2016, e no encontro realizado em Curitiba, na Universidade Federal do Paraná (UFPR), em novembro de 2017. A primeira foi publicada em um dos capítulos do livro "Sindicalismo e associativismo dos Trabalhadores em Educação no Brasil” (Bauer et al., 2017).
} 
investigue mais as relações entre gênero e participação sindical, tendo em vista a pouca produção com esse foco.

No artigo: "Desconforto e invisibilidade: representações sobre relações de gênero entre sindicalistas docentes", Ferreira (2008) aborda as representações sobre relações de gênero na educação e as trajetórias sindicais de diretoras(es) do $24^{\circ}$ Núcleo do Centro dos Professores do Estado do Rio Grande do Sul - Sindicato dos Trabalhadores em Educação (CPERS/Sindicato). Entre as questões que a autora pontua, chama a atenção a importância da ação sindical na experiência profissional e na vida pessoal dos sujeitos.

Por fim, em “'Discutir educação é discutir trabalho docente': o trabalho docente segundo dirigentes da Confederación de Trabajadores de la Educación de la República Argentina (CTERA)”, Ferreira (2009) examina as relações entre sindicalização e percepção do trabalho docente como profissional ou proletarizado, segundo lideranças sindicais de uma central latino-americana de trabalhadores em educação, a CTERA.

Sobre o segundo grupo de leituras citadas por Kaufmann (2013), o autor destaca que a problematização do objeto não é necessariamente conduzida por leituras sobre o tema, mas muitas vezes pela construção de analogias com contextos diferentes, suscitando novos questionamentos e ajudando no desenvolvimento da pesquisa. Foi assim com o trabalho de Lelis (1996), "A polissemia do magistério", no qual a autora aborda as histórias de vida de professoras que atuam em diferentes contextos educacionais, e a importância desses contextos para a constituição de seu "capital pedagógico". Esse trabalho inspirou-me a buscar nas histórias de vida de professores e professoras sindicalizados as contribuições trazidas pelo convívio no espaço sindical à sua formação. Dessa obra também destaco o percurso de sua construção, revelado na riqueza do detalhamento sobre o trabalho de campo.

Como contribuição à metodologia desenvolvida na pesquisa, também destaco a leitura de "A entrevista compreensiva", de Jean-Claude Kaufmann (2013), que para além das orientações sobre a metodologia abordada no título, fornece importantes orientações sobre a pesquisa de campo de modo geral.

Após tal levantamento bibliográfico e a reflexão de caráter sociológico acerca da temática, alguns autores se apresentaram com potencial de interlocução com a pesquisa, seja por sua produção no campo - como Vianna, Ferreira e Xavier - as quais apontam caminhos metodológicos e lacunas a serem suprimidas; seja pelo 
fornecimento de ferramentas para a fundamentação teórica e epistemológica da pesquisa - como o estudo acerca do processo de construção das "identidades profissionais" de Claude Dubar e os conceitos de campo e habitus de Pierre Bourdieu.

As contribuições de Claude Dubar (2005) são importantes para o entendimento do processo de construção das identidades profissionais. Ele põe ênfase na interação entre os sujeitos, ao afirmar que a construção das identidades parte da dualidade social mediante dois processos: o biográfico e o relacional. No primeiro processo, o sujeito constrói uma identidade para si e, no segundo, para o outro. Dessa forma, como declara o próprio autor, ele traz para a análise sociológica, a dimensão subjetiva, diferente das noções de grupo, classe ou categoria, utilizadas em uma perspectiva macrossocial, ou das noções de papel e de status, definidas a partir de uma perspectiva microssocial.

Como mostra o Quadro 1, o autor denomina "atos de atribuição" aqueles que visam definir identidade para o outro; e "atos de pertencimento" os que indicam que tipo de homem (ou mulher) você quer ser, ou seja, a identidade para si.

\begin{tabular}{|c|c|}
\hline $\begin{array}{c}\text { Processo relacional } \\
\qquad *\end{array}$ & $\begin{array}{c}\text { Processo biográfico } \\
\qquad\end{array}$ \\
\hline$*$ & $*$ \\
\hline Identidade para o outro & Identidade para si \\
\hline$*$ & $*$ \\
\hline$*$ & $*$ \\
\hline Atos de atribuição & Atos de pertencimento \\
\hline 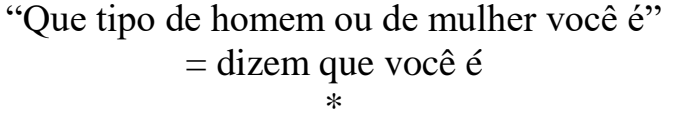 & $\begin{array}{l}\text { "Que tipo de homem ou de mulher você } \\
\text { quer ser" = você diz que você é } \\
* *\end{array}$ \\
\hline$*$ & $*$ \\
\hline Identidade - numérica (nome atribuído) & Identidade predicativa de $\mathrm{Si}$ \\
\hline - genérica (gênero atribuído) & (pertencimento reivindicado) \\
\hline$*$ & $*$ \\
\hline$*$ & $*$ \\
\hline Identidade social "virtual" & Identidade social "real" \\
\hline$*$ & $*$ \\
\hline$*$ & $*$ \\
\hline Transação objetiva entre & Transação subjetiva entre \\
\hline - identidades atribuídas/propostas & - identidades herdadas \\
\hline - identidades assumidas/incorporadas & - identidades visadas \\
\hline$*$ & $*$ \\
\hline$*$ & $*$ \\
\hline Alternativa entre & Alternativa entre \\
\hline - cooperação - reconhecimento & - continuidades $\rightarrow$ reprodução \\
\hline - conflitos - não reconhecimento & - rupturas $\rightarrow$ produção \\
\hline
\end{tabular}




\begin{tabular}{|cc|}
\hline$*$ & $*$ \\
$*$ & $*$ \\
"Experiência relacional e social & "Experiência de estratificações, \\
do poder" & discriminações \\
$*$ & e desigualdades socais" \\
$*$ & $*$ \\
Identificação com instituições & Identificação com categorias \\
$*$ & consideradas atraentes ou protetoras \\
$*$ & $*$ \\
$*$ Identidade social marcada pela dualidade & $*$ \\
\hline
\end{tabular}

Quadro 1 - Categorias de análise da identidade

Fonte: Dubar (2005, p. 142).

Portanto, trata-se de dois processos distintos: o primeiro concerne à atribuição da identidade pelas instituições e pelos agentes que estão em interação direta com os indivíduos, o qual, segundo Dubar (2005), só pode ser analisado no interior dos sistemas de ação nos quais o indivíduo está implicado, e resulta de "relações de força" entre todos os atores envolvidos e da legitimidade das categorias utilizadas. O segundo processo diz respeito à interiorização ativa, à incorporação da identidade pelos próprios indivíduos. Para o autor, ela só pode ser analisada no interior das trajetórias sociais pelas e nas quais os indivíduos constroem "identidades para si" que nada mais são que a "história que eles contam sobre o que são" e que Goffman denomina identidades sociais "reais". (Dubar, 2005 p. 139).

"As estratégias identitárias" têm a finalidade de reduzir a distância entre a identidade social "virtual" conferida a uma pessoa e a identidade social "real" que ela mesma se atribui, quando há "desacordo" entre elas, podendo assumir duas formas: as transações "externas" ou transação objetiva entre o indivíduo e os outros significativos, visando a tentar acomodar a identidade para si à identidade para o outro; ou a de transações "internas" ao indivíduo, entre a necessidade de salvaguardar uma parte de suas identificações anteriores (identidade herdadas) e o desejo de construir para si novas identidades no futuro (identidades visadas), com vistas a tentar assimilar a identidade para o outro à identidade para si. "Essa transação, denominada subjetiva constitui um segundo mecanismo central do processo de socialização concebido como produtor de identidade sociais." (Dubar, 2005, p. 140). 
Quanto ao campo profissional, Dubar afirma que a construção biográfica se dá nas relações de trabalho, "participar de alguma forma das atividades coletivas em organizações, intervir de uma maneira ou de outra em representações."

O fato de poder "jogar" com diferentes espaços e, dessa forma, poder "negociar" seus investimentos e "administrar" seus pertencimentos constitui um elemento essencial da transação objetiva. Os parceiros dessa transação são, com efeito, múltiplos: o grupo dos pares no interior da seção, do escritório ou da equipe de trabalho, o superior hierárquico ou outros responsáveis pela empresa, o dirigente sindical ou o representante local, o formador, mediador do universo e da formação, o cônjuge e o universo da família, etc. (Dubar, 2005, p. 155).

Todos esses sujeitos constituem o "outro" significativo a quem se tenta acomodar a identidade para si, de modo que cada um deles poderá ter influências diferentes no processo relacional de construção da identidade profissional.

Quanto aos conceitos da obra de Bourdieu, Brandão (2010) destaca a importância de trata-los com e para além do autor, pois embora sua teoria seja ampla, ela é datada e marcada pelo contexto francês. Por isso, na tentativa de "pôr em jogo as coisas teóricas" debruço-me sobre os conceitos de campo e habitus, relacionando-os ao estudo da filiação sindical docente.

Em "Razões práticas”, Bourdieu (2013) reflete sobre a possível validade dos modelos por ele construídos, a partir do caso específico da França, expondo o que acredita ser essencial em seu trabalho, a saber:

uma filosofia da ação, chamada às vezes de disposicional, que atualiza as potencialidades inscritas nos corpos dos agentes e na estrutura das situações nas quais eles atuam ou, mais precisamente, em sua relação. Essa filosofia condensada em um pequeno número de conceitos fundamentais - habitus, campo, capital - e que tem como ponto central a relação, de mão dupla, entre as estruturas objetivas (dos campos sociais) e as estruturas incorporadas (do habitus) [...]. (Bourdieu, 2013, p. $10)$.

Portanto, o habitus é um conceito extremamente importante desse autor, pois é estruturado e, ao mesmo tempo, estruturante. "São princípios geradores de práticas distintas e distintivas" (Bourdieu, 2013, p. 22). Assim, as razões que conduzem os professores à filiação sindical podem ser analisadas a partir desse conceito. Para isso, foi necessário compreender quais as estruturas socais - de natureza cultural, socioeconômica e demográfica - constituíram o habitus desses professores; buscar também o entendimento de como o habitus desses indivíduos estruturaram suas práticas. 
O conceito de campo como espaço simbólico de lutas concorrenciais também ajudou a compreender os diversos posicionamentos dentro do movimento sindical dos professores, especialmente ao considerarmos sua interseção com o campo do espaço escolar enquanto locus de ação do professor.

Há uma estreita relação entre os conceitos de campo e habitus, pois a frequência a uma diversidade de campos e a acumulação de novos capitais culturais a eles relacionados podem conduzir diferentes habitus, no caso dos professores, a diferentes "habitus professorais" (Silva, 2011). Nessa perspectiva, foi interessante perceber que dentro desse grupo profissional a frequência ao sindicato deixa "marcas" nos sujeitos que os distinguem daqueles que não são atuantes.

Outra questão importante são os diferentes níveis de participação e posição ocupada dentro desse campo: "Os campos, por onde os agentes circulam levados pela necessidade de estar no jogo social, são o locus onde operam, capitalizam-se e alteram-se os habitus em consequência da mobilização de tipos diferentes de capital.” (Brandão, 2010, p. 231).

Assim, os conceitos de habitus e campo, de Bourdieu, contribuíram para o desenvolvimento da pesquisa e me pareceram profícuos na análise da filiação docente e suas implicações nas relações estabelecidas no campo escolar.

O diálogo com cada um desses trabalhos aqui mencionados será tecido ao longo dessa tese, mediante a análise dos dados empíricos.

\subsection{2}

Questionários

Ao elaborar o projeto, pretendia iniciar a pesquisa a partir de um panorama geral dos participantes do movimento sindical em Duque de Caxias, utilizando as fichas de filiação ao sindicato ${ }^{7}$, mas isso foi não foi possível, pois tais documentos estavam desatualizados. A direção do sindicato informou que muitos professores saíram de suas escolas de origem, mudaram de situação funcional ao se aposentar ou avançar na carreira. Além disso, havia poucas informações nas fichas de filiação,

\footnotetext{
${ }^{7}$ Em contraposição à filiação compulsória, o Sepe trabalha com adesão voluntária, rejeitando, inclusive, o imposto sindical. Portanto, o profissional que deseja ser representado deve preencher uma ficha de autorização de desconto que é enviada à prefeitura para que mensalmente haja o repasse ao SEPE referente à $1 \%$ do valor do vencimento. A ficha de filiação ao Sepe consta no Anexo B desta tese.
} 
como: dados básicos de identificação (nome, endereço, telefone, data de nascimento, estado civil e número de documentos), além de matrícula e local de trabalho, que não respondiam às questões que vinham sendo levantadas no estudo.

De acordo com Kaufmann (2013), no percurso da pesquisa é necessário que o pesquisador seja flexível, que mantenha "sua caixa de ferramentas" de pesquisa aberta, e faça sempre um balanço, avaliando a necessidade de acelerar, retardar, mudar de instrumentos ou de direção da pesquisa.

Assim, dada a impossibilidade de levar adiante a ideia da análise das fichas de filiação, o questionário me pareceu o instrumento mais adequado à construção de dados iniciais que permitissem ter um panorama dos professores filiados e sua participação junto ao sindicato.

Como o foco da pesquisa é qualitativo e não quantitativo, a ideia era que esse questionário tivesse o mínimo de questões possíveis para que fosse aplicado em assembleia durante a data-base, quando eu teria acesso a um quantitativo maior de professores sindicalizados, extraindo informações básicas que pudessem ser cruzadas posteriormente com as observações e entrevistas.

Desse modo, fiz uma adequação nas estratégias e busquei os dados mais gerais por meio de um questionário (Apêndice A) com 18 questões, totalizando 42 variáveis, posteriormente tabuladas e analisadas com auxílio do software IBM SPSS.

O questionário foi dividido em duas partes: identificação e participação sindical. A primeira parte trata da formação; situação, nível funcional e função ou funções exercidas na rede municipal de Duque de Caxias; ano de ingresso na rede; concomitância com outro trabalho; dados demográficos e posição sindical ${ }^{8}$. A segunda parte do questionário tem natureza mais abrangente, abordando questões de filiação, representatividade, participação, possíveis reflexos dessa participação nas relações dentro da escola e formação no espaço sindical.

A primeira parte do questionário conta apenas com perguntas fechadas, enquanto a segunda possui um conjunto de questões abertas que dão maior liberdade para o respondente se colocar.

\footnotetext{
8 "Posição sindical" é entendida nesta tese como o lugar que o profissional ocupa dentro do movimento sindical: se pertence apenas à base da categoria; ao conselho de representantes ou à direção do sindicato.
} 
Quanto à aplicação, a distribuição dos questionários foi previamente anunciada pela direção do sindicato entre os informes da assembleia, tendo em vista, que esta respaldou a realização da pesquisa. Os questionários foram impressos em papel A4 na cor verde para que se destacassem em meio aos panfletos e informes comumente distribuídos nas assembleias. Durante a aplicação, fiquei de pé, ao lado do livro de assinaturas de frequência, para a entrega dos questionários e ao final passei de fileira em fileira solicitando o seu retorno e esclarecendo eventuais dúvidas. Foram aplicados 213 questionários em quatro assembleias ${ }^{9}$.

Sobre o perfil dos respondentes, de modo geral, os questionários foram respondidos por componentes da base da categoria. São 196 membros da base, sendo que 44 deles desempenham o papel de representantes de suas escolas junto ao sindicato e 10 questionários foram respondidos por membros da direção colegiada do núcleo Sepe/Caxias.

A maioria dos respondentes (155) ocupa a função de professor dos anos iniciais do ensino fundamental (concurso para professores formados em nível médio). Os especialistas e professores dos anos finais do ensino fundamental somaram 52 respondentes.

Há predominância feminina: são 181 mulheres para 32 homens, confirmando o que aponta Gatti \& Barreto (2009, p. 17) sobre os postos de trabalho para os profissionais do ensino serem $77 \%$ ocupados por mulheres. Embora o espaço sindical tenha sido historicamente de predominância masculina (Ferreira, 2008), no que tange ao sindicalismo docente, isso parece ser relativo, tendo em vista que a base da categoria é composta majoritariamente por mulheres.

No que diz respeito à cor da pele, 121 professores se reconhecem como negros ou pardos, 79 brancos, 2 amarelos e 2 indígenas. Algumas críticas aos campos "cor/raça" e "sexo" foram tecidas nos questionários por três respondentes, que se disseram incomodados com a questão do "binarismo", no que diz respeito ao sexo e à padronização e uso do termo "raça". Esses termos seguiram os padrões das pesquisas demográficas do IBGE, para fins de facilitar possíveis comparações com outros trabalhos posteriormente.

Ao final do questionário, um espaço foi destinado para comentários, críticas e sugestões relacionadas ao sindicato e a pesquisa. Alguns deles mostram como o

\footnotetext{
${ }^{9}$ As assembleias ocorreram em: 12/05, 08/06, 10/06 e 07/07 de 2016.
} 
campo esteve aberto ao tema e que os sujeitos demonstraram solicitude em colaborar com a pesquisa:

Gostaria de sinalizar o prazer de participar desta pesquisa, não só pela relevância deste estudo, mas também pelo respeito à companheira de luta que desenvolve esta pesquisa. Provavelmente, estarei me aposentado ano que vem; e é muito bom saber que há um grupo de jovens militantes que são responsáveis e respeitosos na luta. Encaminhar o processo de aposentadoria não significa afastamento da luta, mas saber que existem companheiros jovens "oxigena" e "revitaliza" a luta. (Prof ${ }^{a} . \mathrm{K}$ ).

No caso deste relato, a professora faz referência a mim enquanto colega de luta que desenvolve uma pesquisa sobre o sindicato, o que a faz crer que a nova geração de professores reconhece o movimento sindical construído por sua geração e que o levará adiante. Essa certamente pode ter sido a motivação para participação de outros respondentes do questionário, a valorização do movimento ao qual faz parte.

Outro fato que chamou minha atenção é que mesmo sendo explicitado no caput do questionário o direito do participante ao anonimato, muitos respondentes fizeram questão de se identificar. As demais respostas ao questionário serão analisadas ao longo da tese, em especial, no capítulo 4, em diálogo com os dados produzidos nas observações e entrevistas.

\subsection{3 \\ Observações}

A ideia de acompanhar o cotidiano sindical surgiu da necessidade de construir um olhar sobre como esse espaço é vivido por seus atores e, assim, compreender a dinâmica construída na coletividade e experienciada por professores engajados através da aproximação direta e cumplicidade nas ações. Encontrar os sentidos das ações dos sujeitos e compreendê-los torna-se tarefa menos complexa ao "vestir sua pele".

Como já expressei anteriormente, eu possuía um envolvimento com o grupo sindical, porém, a experiência de participante é despreocupada da curiosidade científica que hoje como pesquisadora me aguça a compreender o processo formativo no espaço sindical, afinal "que sabe um peixe acerca da água em que 
nada durante toda sua existência?"10 Somente agora, desenvolvendo a pesquisa, pude mergulhar com mais profundidade na tentativa de refletir sobre ação dos indivíduos e grupos envolvidos, acompanhando atentamente como se dá esse processo.

As observações ocorreram de julho de 2015 a julho de 2017. Nesse período de dois anos, houve um grande esforço em olhar para o espaço, ao qual eu já frequentava como professora sindicalizada, agora com os olhos de pesquisadora. Precisei manter o equilíbrio entre os dois papéis, já que não seria possível um maior distanciamento, que me abstivesse do papel de professora.

Obviamente, esse esforço não foi uma tentativa de construção de uma neutralidade, mas o aguçar dos sentidos para outras perspectivas daquilo que outrora me passava despercebido por ser familiar. Tura (2011) sugere que o pesquisador não se iluda em procurar eliminar os efeitos de sua presença no campo de investigação, mas que busque entendê-los.

Se por um lado, houve a necessidade de certo distanciamento do senso comum trazido pelo lugar de participante no movimento sindical, por outro, o envolvimento, interesse e curiosidade cresciam cada vez mais, levando-me a uma observação participante.

Sempre com caderno e caneta na mão, a curiosidade sobre o que eu escrevia ou gravava despertava a atenção de alguns membros do sindicato, mas logo foi sendo cessada pela recorrência de minha figura nas reuniões, sentada quase sempre nos bancos da frente e no canto da parede, onde podia ouvir com atenção tudo o que era dito e olhar para o restante da plenária, inclinando levemente meu corpo para o lado. Tudo era observado e minuciosamente anotado em meu inseparável caderno de campo.

As observações ocorreram em todos os fóruns ordinários e extraordinários do movimento sindical em Duque de Caxias. Isso custou um longo tempo de acompanhamento e registro das pautas. Houve períodos de intensa concentração de atividades, nos quais uma série de encontros eram promovidos em um período curto de tempo.

Para que a observação tivesse efeito, voltei o olhar para o objetivo de cada reunião, para a atuação dos participantes, suas falas e ações. Os resultados das

\footnotetext{
${ }^{10}$ Albert Einstein, Autorretrato 1935.
} 
observações foram três cadernos de campo repletos de anotações nas quais registrei as falas, os conflitos, as emoções e dinâmicas vividas a cada passo do movimento sindical docente em Duque de Caxias.

A releitura desses cadernos teve fundamental importância para me fazer lembrar de situações vivenciadas, reviver discussões, revisitar o clima de cada momento... Os registros são aliados do pesquisador e devem, portanto, ser realizados com todo cuidado e minúcia para que nada lhes escape. Ainda assim, como são uma seleção, pelo fato de ser impossível detalhar cada instante e captar tudo o que se passa ao nosso redor nas linhas e entrelinhas, eles devem ter um foco pré-determinado em uma pauta de observação que, é claro, não pode ser uma amarra ao olhar do pesquisador.

Essa pauta, elaborada ainda na construção do projeto de pesquisa, foi sofrendo alterações à medida que a própria empiria revelava a necessidade de novos enquadramentos.

Também fiz registros fotográficos, de vídeo e de áudio ${ }^{11}$ e criei arquivos digitais e físicos de acompanhamento ${ }^{12}$ das ações, materiais e atividades desenvolvidas pelo sindicato ao longo do período de observação. O cruzamento desse conjunto de materiais mostrou a dimensão da dinâmica vivida pelo grupo.

Ademais, chamaram a atenção os fóruns on-line que se formaram ao longo desse percurso. As inovações tecnológicas cada dia mais acessíveis por intermédio da difusão dos smartphones, chegaram com bastante força ao sindicalismo, sendo usadas (especialmente as redes sociais) como ferramentas de comunicação rápida para formulação de estratégias, disseminação de ideias e discussões.

Diante dessa novidade, não poderia deixar de assinalar a importância desses canais utilizados pelo movimento sindical e apontá-los como uma rica fonte de pesquisa para futuros pesquisadores que se interessarem pela temática do sindicalismo. Fiz a tentativa inicial de incorporá-los às análises presentes nesta tese, acompanhando as discussões do "grupo de representantes" criado no WhatsApp pela direção do sindicato, entre outros grupos criados pela base da categoria. No entanto, dada a fluidez dessas mídias e multiplicidade de canais de comunicação expressa que se abrem a cada dia em grupos de mensagem instantânea e redes de

\footnotetext{
${ }^{11}$ Obtive o consentimento para os registros aprovados pelos participantes em assembleia.

12 Esses arquivos são pastas com fotos, panfletos, cartazes, informativos entre outros materiais produzidos, divulgados e/ou distribuídos pelo sindicato.
} 
compartilhamento de fotos e vídeos, optei por priorizar as análises das observações realizadas nos fóruns presenciais.

\subsection{4 \\ Entrevistas sobre a trajetória de vida}

Por meio das entrevistas semiestruturadas, busquei nas trajetórias de vida as razões e influências que conduziram os sujeitos a se sindicalizar (Ferreira, 2008) especialmente aqueles que participam ativamente do movimento sindical. Observando que essa trajetória não é linear, procurei compreender os diferentes sentidos dessa participação.

A partir da trajetória de vida, Silva (2012) analisou como um grupo de professores constituiu uma identidade profissional intimamente vinculada ao movimento sindical, possibilitando, inclusive, que alguns deles tenham se transformado em liderança dentro desse movimento. Em entrevistas com professores da Baixada Fluminense, a autora buscou "compreender de que maneira os espaços de socialização - movimento estudantil, movimento social, igreja, movimento operário, movimento de esquerda e família - contribuíram para a constituição da identidade sindical" (Silva, 2012, p. 7) desse grupo de professores.

De semelhante modo, na presente pesquisa procurei compreender as influências da participação sindical na constituição da identidade profissional dos professores e as contribuições dessa participação em sua formação.

Em "O recurso às histórias de vida para o estudo de trajetórias profissionais", Lelis \& Nascimento (2010) analisam a fecundidade das histórias de vida como fonte para as pesquisas sobre trabalho docente e formação de professores. Esse procedimento metodológico propiciou que "um conjunto de dimensões da vida dos professores aparecesse e ajudasse a entender seus habitus profissionais, suas formas de comunicação pedagógica, seus processos de socialização [...].” (p. 91).

As autoras trazem a importância do uso dessa ferramenta metodológica e a sua potencialidade para o campo das ciências sociais sem, contudo, deixar de apresentar as principais críticas ao uso desse recurso, especialmente as elencadas por Bourdieu (2013) em seu artigo "A ilusão bibliográfica", no qual coloca em xeque o uso de depoimentos como fonte de pesquisa. 
Por tratar da "subjetividade, memória, discurso e diálogo" a história de vida pode ser entendida como estritamente relativa ao indivíduo, mas de acordo com Lelis \& Nascimento (2010, p. 93):

As narrativas, embora feitas por indivíduos, evidenciam mais que elementos da existência individual, pois através delas é possível captar as relações do narrador com os membros do seu grupo social, profissão, sua sociedade. Busca-se, com as histórias de vida, atingir a coletividade de que seu informante faz parte.

Dentro de um contexto de desprestígio social da profissão docente, as autoras consideram importante tomar a história de vida do professor como forma de valorizar sua trajetória pessoal e profissional, entendendo que estão mutuamente relacionadas:

Valorizar o papel do professor na construção de uma nova escola implica considerar a história de vida como um dos caminhos para construir um "outro" conhecimento acerca dos professores, dos trabalhos que realizam e das instituições escolares, conhecimento que não separe a dimensão pessoal da dimensão profissional. (Lelis \& Nascimento, 2010, p. 97).

A partir da afirmação de que as "histórias de vida dos professores apontaram para os modos de ensinar em sala de aula", tentamos considerar tanto as trajetórias de vida dos professores no que diz respeito à chegada ao movimento sindical influências familiares, sociais e profissionais - quanto o reflexo dessa participação na docência. Ainda segundo as autoras, o “capital pedagógico" é elaborado no percurso profissional, incluindo ideias, valores, saberes e práticas que os professores vão construindo ao longo de sua vida.

Verifiquei também o conjunto de possibilidades ou dificuldades encontradas pelo professor ao participar do movimento. Nesse sentido, foi válido averiguar nas entrevistas a influência, apoio ou não da família dos militantes; suas origens socioeconômicas, o envolvimento político e social de seus pais; a atual estrutura familiar e de trabalho; o nível de instrução de cada participante e pensar sociologicamente essas questões.

Outra questão que tentei captar nas entrevistas foi o significado da experiência sindical para os sujeitos da pesquisa e o que mudou em suas vidas profissionais a partir da aproximação com o sindicato. Utilizando os termos de Ferreira (2008), é importante examinar se a atividade sindical pode ser vista como um "motor" que impulsiona o professor para a busca de sua profissionalidade. A 
autora cita dois aspectos importantes da ação sindical na experiência profissional e pessoal dos sujeitos:

Primeiro, a atividade sindical forneceu-lhes uma visão de mundo e conhecimentos sobre a realidade social que não tinham o que se reverte na educação de seus alunos, embora haja o receio de que a influência seja direta demais. Segundo, sublinham a qualificação do trabalho pedagógico como algo que justifica a luta sindical [...]. (Ferreira, 2008 p. 27).

As mudanças no âmbito profissional, sejam a respeito do conhecimento e a vivência da profissão, ou no relacionamento entre os pares, estiveram presentes nas entrevistas na tentativa de compreender as percepções dos professores sobre a influência sindical na sua profissionalidade.

A escolha dos entrevistados foi baseada nas observações feitas ao longo do trabalho de campo junto ao sindicato. Elegi os sujeitos que pareciam ter uma participação contínua e significativa para o sindicato na atualidade. Também procurei aqueles que tinham uma atuação histórica dentro do Sepe/Caxias, principalmente no que diz respeito à formação.

Busquei ponderar certos critérios que permitissem que o conjunto de entrevistados contemplasse, minimamente, a diversidade dos participantes no movimento sindical, com pessoas de diferentes funções na rede, professores dos anos iniciais e finais do ensino fundamental, orientadores pedagógicos e educacionais (Kaufmann, 2013).

Também diversifiquei o conjunto de entrevistados do ponto de vista geracional e de gênero, sabendo que o quantitativo de mulheres é bem maior que o de homens e que, portanto, deveriam ser ouvidas mais professoras que professores. Além disso, estabeleci um tempo mínimo de 5 anos de matrícula na rede municipal de Duque de Caxias, especialmente em atuação sindical, seja como direção, representante de escola ou na base da categoria.

A observância desse último critério foi necessária para que os sujeitos tivessem elementos suficientes para falar de seu processo de formação junto ao sindicato. Em contrapartida, a adoção de tal barreira impôs certos limites, pois excluiu uma série de novos profissionais que chegaram aguerridos à luta após a última chamada do concurso, em 2016. Mas, em se tratando de história de vida, acreditamos ter sido esse o caminho mais viável.

Ainda na fase de elaboração do projeto, defini que as entrevistas seriam realizadas no segundo semestre letivo de 2016, logo após um ano de observações, 
para que o campo pudesse sugerir quem seriam os sujeitos mais adequados a contribuir nessa etapa da pesquisa.

No entanto, o cenário político se acirrou no município de Duque de Caxias ${ }^{13}$ e em todo o Brasil, com gradativos problemas de ordem econômica, desencadeando parcelamentos de salário até se chegar ao não pagamento dentro do mês, com atraso de mais de três meses de salário, fazendo com que o movimento sindical se intensificasse.

Protestos com atos, vigília ${ }^{14}$ a cada nova audiência, reunião de pais, reunião do conselho de representantes, e corrida às escolas eram uma constante a cada dia, impedindo, pelo bom senso, a tentativa de marcar qualquer entrevista que sobrecarregasse ainda mais os participantes do movimento sindical. Sobretudo porque a ideia era que as entrevistas se iniciassem pela direção do sindicato, que inclusive poderia nos apontar novos sujeitos significativos dentro do campo.

Diante desse quadro, uma adequação foi necessária: a ampliação e intensificação do período de observação e o adiamento das entrevistas, para o primeiro semestre de 2017. A única entrevista realizada no ano de 2016 aconteceu antes da data-base, no mês de março, quando o cenário político-econômico da cidade ainda contava com certa estabilidade. A entrevistada foi uma professora das séries iniciais da EJA, militante representante de sua escola no sindicato.

Essa entrevista serviu de base para realização das demais, assim como trouxe alguns elementos a serem observados junto ao movimento sindical. As demais entrevistas ocorreram entre os meses de janeiro a julho de 2017, seu conteúdo e análises serão considerados nos demais capítulos da tese.

\section{4 \\ Campo empírico}

A pesquisa foi realizada em um dos núcleos sindicais mais ativos do Sindicato Estadual dos Profissionais da Educação do Rio de Janeiro (Sepe), no município de

\footnotetext{
${ }^{13}$ O governo Alexandre Cardoso (PSB) inaugurou em Duque de Caxias, a prática de parcelamentos de salários no mês de maio de 2016, logo após o término da greve dos professores em 25/04/2017. Tal política perdurou até o fim de seu mandato, sendo também adotada pelo seu sucessor, Washington Reis (PMDB) sobre o pretexto da crise econômica no Estado.

${ }^{14}$ Em Duque de Caxias, dá-se o nome de vigília o ato de aguardar as longas audiências do lado de fora.
} 
Duque de Caxias, situado na região metropolitana do Rio de Janeiro, na Baixada Fluminense.

Para contextualizar o campo, apresento, a seguir, os contornos políticoeconômicos do município de Duque de Caxias; trago a estrutura organizativa do Sepe/RJ, situando o lugar do núcleo municipal de Duque de Caxias nessa entidade; resgato, brevemente, a história do Sepe/Caxias e descrevo o contexto no qual a pesquisa foi realizada.

\subsection{1 \\ Duque de Caxias, um município da Baixada Fluminense}

Vizinho ao Rio de Janeiro, Duque de Caxias é um dos municípios mais antigos da Baixada Fluminense; foi distrito de Nova Iguaçu até ter sua emancipação em 1943. Hoje, possui posição de destaque entre os municípios do Rio de Janeiro, por ser a segunda maior economia do Estado (em 2014). Entre os 5.570 municípios do Brasil, Duque de Caxias atingiu a 22 $2^{\mathrm{a}}$ posição entre os maiores PIBs. De acordo com Souza (2014, p. 12):

Sua proximidade com a cidade do Rio de Janeiro foi facilitada pela construção das Linhas Vermelha e Amarela. A duplicação da Rodovia Washington Luís e os incentivos municipais atuaram como atrativos a novos investimentos, principalmente na ampliação do polo petroquímico e na inauguração do polo gás químico. Um outro setor que vem se destacando é o do consumo, retratado pelos investimentos na instalação de shoppings, hipermercados e lojas de marca que concorrem com os pequenos e médios comerciantes.

Esta é uma cidade repleta de desigualdades, onde a riqueza produzida por seu vasto comércio e indústria, contrasta com a pobreza de sua população, que enfrenta graves problemas nas áreas de educação, habitação e saúde. De acordo com o último censo, o IDHM de Duque de Caxias era de 0,711, posição no 1.574 entre os municípios brasileiros ${ }^{15}$.

É conhecida como uma "cidade dormitório", pois parcela significativa da sua população trabalha no município do Rio de Janeiro e se utiliza principalmente do trem e dos ônibus como meio de transporte para chegar à cidade vizinha. As principais vias de acesso da cidade são a Linha Velha, Avenida Brasil e Rodovia Washington Luís.

\footnotetext{
${ }^{15}$ Disponível em: <http://www.atlasbrasil.org.br/2013/pt/ranking/>. Acesso em: 7 mar. 17.
} 
Além da BR-040 (Rio-Petrópolis), Caxias também é cortada por outras importantes vias como a rodovia Rio-Teresópolis e o Arco Metropolitano, pelas quais escoa a produção industrial do município.

Na história da educação, antes mesmo de sua emancipação, constam relatos significativos, como a experiência da Escola Regional do Meriti, dirigida por Armanda Álvaro Alberto, um projeto ativo e pioneiro na distribuição de merenda escolar como medida de permanência da população carente atendida. Além da articulação com artistas e intelectuais que contribuíram para seu projeto educativo (Lazaroni, 2010).

Com um quantitativo de 62.928 alunos matriculados na escola e com $2.430^{16}$ professores em sua rede municipal, Duque de Caxias possui 178 escolas que atendem da educação infantil ao ensino fundamental. No ano de 2016, o Ideb das escolas municipais de Duque de Caxias, era de 4.4 nos anos iniciais e 3.3 nos anos finais do ensino fundamental ${ }^{17}$, isto é, respectivamente 0.2 e 0.5 abaixo da média nacional ${ }^{18}$.

A ausência de um padrão adequado à construção dos prédios escolares associada à existência de inúmeros "puxadinhos", característicos da cultura brasileira de se contornar o abandono governamental com o famoso "jeitinho brasileiro", resulta na precariedade da estrutura física das escolas.

Do ponto de vista político-administrativo, Duque de Caxias tem um histórico de governos omissos, que não se voltam às necessidades básicas da população, como educação e saúde. Impera na cidade a cultura da política de troca de favores em detrimento da garantia do estado de direito.

Pesa sobre o município as marcas de violência sofrida ao longo de sua história pela presença de grupos extermínio e sua vinculação com a política (Alves, 2003). Ainda hoje, Duque de Caxias, apresenta altos índices de violência.

Contudo, a cidade possui um histórico de lutas e reivindicações que remontam a sua emancipação em meados do século XX (Souza, 2014). Atualmente, Duque de

\footnotetext{
16 Disponível em: <http://www.cidades.ibge.gov.br/xtras/perfil.php?lang=\&codmun=330170\&search=||infogr\%E1fic os:-informa\%E7\%F5es-completas>. Acesso em: 25 jan. 2016.

${ }^{17}$ Disponível em: <http://ideb.inep.gov.br/resultado/resultado/resultadoBrasil.seam?cid=106208>. Acesso em: 26 jul. 2016.

${ }^{18}$ Disponível em: <http://www.qedu.org.br/cidade/2751-duque-de-caxias/ideb>. Acesso em: 25 jan. 2016.
} 
Caxias conta com uma série de movimentos que contribuem para a afirmação de sua história e valorização de sua identidade, o Centro de Pesquisa, Memória e História da Educação da Cidade de Duque de Caxias e Baixada Fluminense (Cepemhed) e o Museu Vivo do São Bento são alguns desses espaços.

O Cepemhed tem por objetivo resgatar e preservar as memórias da educação, não apenas do município de Duque de Caxias, como também dos outros municípios que compõe a região da Baixada Fluminense:

Se propõe a oportunizar um espaço de fomento à produção e divulgação de pesquisas; de formação docente; de arquivamento e tratamento de dados coletados sobre a história e as memórias da educação do município e da Baixada Fluminense, igualmente, de educação patrimonial. (Cepemhed - Folder de divulgação).

O Museu Vivo de São Bento é um eco museu de percurso. Foi criado a partir das reivindicações dos profissionais da educação e movimentos culturais caxienses. Além do caminho histórico que o constitui, o museu promove exposições, programas e projetos educativos, inclusive destinados aos profissionais da educação da cidade em parceria com o sindicato.

Além desses dois importantes centros de pesquisa, memória e formação de professores, Duque de Caxias ganha destaque por diversos outros movimentos de luta, especialmente pelo sindicato docente, sendo o seu núcleo um dos mais atuantes do Sindicato Estadual dos Profissionais da Educação do Rio de Janeiro (Sepe). A seguir, trato especificamente da estrutura e história desse núcleo sindical.

\section{4 .2}

O Sepe e seu núcleo sindical em Duque de Caxias

Para entender a dimensão do núcleo Duque de Caxias, é fundamental compreender um pouco da história e da estrutura do Sepe/RJ. De acordo com o site oficial da instituição, o início de sua história se deu com a união da Sociedade Estadual dos Professores (SEP, nascida em 1977), União dos Professores do Rio de Janeiro (Uperj) e da Associação dos Professores do Estado do Rio de Janeiro (Aperj), resultando na criação do Centro de Professores (CEP) do Rio de Janeiro.

A princípio, sua representação era restrita aos professores, mas 1987, depois de anos de discussões, foi aprovada, no terceiro congresso da entidade - a ampliação do quadro de sócios, incluindo os demais profissionais de educação que 
não eram professores, passando a se chamar Centro Estadual dos Profissionais de Educação (Cepe).

A partir de outubro de 1988, com a nova Constituição Federal, os funcionários públicos passaram a ter direito à sindicalização. Foi então que o ainda "Cepe" realizou sua Conferência de Educação, onde passou a chamar-se Sindicato Estadual dos Profissionais de Educação (Sepe), decisão referendada também no IV Congresso, em 1989.

Assim, ao longo de sua história, e principalmente nesse princípio reorganizador do sindicalismo público (Sobreira, 2001) o Sepe adota essa característica de incorporar outras associações que passam a ampliar o seu quadro de representados. Isso ocorreu também na história do Sepe/Caxias, o qual se unificou à Associação de Profissionais da Educação da Prefeitura Municipal de Duque de Caxias (APPMDC).

Atualmente, o Sepe/RJ é dirigido por um colegiado composto por 48 membros, distribuídos pelas seguintes coordenações e secretarias ${ }^{19}$ :

A - Coordenação Geral, da capital, do interior e do Grande Rio.

B - Secretarias: de Organização, de Finanças, de Imprensa, de Aposentados, de Funcionários Administrativos, de Assuntos Educacionais, de Formação e Cultura, de Assuntos Jurídicos, Secretaria de Gênero e Combate à Homofobia.

Cada núcleo ou regional goza de autonomia política e sindical, desde que não contrarie o estatuto do Sepe/RJ e as deliberações feitas em congressos, assembleias gerais, conselhos deliberativos e conferências. Os núcleos possuem direção colegiada e conselho de representantes das escolas ${ }^{20}$, com caráter consultivo e deliberativo.

O núcleo sindical de Duque de Caxias foi fundado oficialmente em 1990, porém com histórico de organizações de lutas desde 1979. De acordo com sua direção, possui hoje cerca de 5.300 filiados, entre ativos e inativos. É um dos núcleos mais bem-sucedidos no Estado do Rio de Janeiro, com conquistas no plano de carreira que o diferenciam dos demais.

\footnotetext{
${ }^{19}$ Ver organograma no Anexo C.

${ }^{20}$ Segundo a direção do sindicato, nem todos os núcleos conseguiram organizar seus conselhos de representantes, tal como funciona em Duque de Caxias com pelo menos uma reunião mensal.
} 
Vários membros que compõem o atual colegiado de diretores do Sepe/Caxias estiveram ou fazem parte da direção do Sepe/RJ, demonstrando o papel de destaque desse núcleo no movimento sindical do Estado do Rio de Janeiro.

Ao longo da tese, trarei mais informações sobre o cotidiano e experiências de formação dentro do Sepe/Caxias, revelando com maior minúcia suas práticas e lógicas de ação, bem como a atuação dos seus participantes. 


\section{2 \\ Os sujeitos e suas histórias}

Cada universo pessoal tem suas riquezas com uma imensidão de coisas a nos ensinar.

Kaufmann

Este capítulo é dedicado a apresentar os professores e professoras que compartilharam sua história de vida, formação e militância, destacando a importância da participação de cada sujeito na pesquisa, o processo de aproximação e abertura à narrativa de sua trajetória.

Para o relato das trajetórias, foram propostos os seguintes eixos: origem familiar; formação; trajetória sindical e exercício da docência, sendo o primeiro eixo um dos alvos privilegiados neste capítulo, dada a importância da primeira socialização para a construção das trajetórias individuais (Nogueira, 1998; Dubar, 2005).

Como anunciado no capítulo anterior, o trabalho com histórias de vida objetiva pela via da análise das trajetórias individuais, atingir a compreensão de uma coletividade, no caso dessa pesquisa, o sindicalismo docente em Duque de Caxias. "Nessa perspectiva, cada indivíduo tem muito a dizer não apenas sobre suas experiências pessoais, mas também sobre o contexto onde essas experiências se forjam.” (Lelis \& Nascimento, 2010, p. 93).

As memórias de militantes são bastante significativas na compreensão das identidades construídas a partir do movimento sindical. Velho (1994) reforça essa ideia ao estabelecer relações entre memória e projeto e sua importância para a constituição de identidades:

A consciência e valorização de uma individualidade singular, baseada em uma memória que dá consistência à biografia, é o que possibilita a formulação e condução de projetos. Portanto, se a memória permite uma visão retrospectiva mais ou menos organizada de uma trajetória e biografia, o projeto é a antecipação no futuro dessas trajetórias e biografia, na medida em que busca, através do estabelecimento de objetivos e fins, a organização dos meios através dos quais esses poderão ser atingidos. A constância do projeto depende, fundamentalmente, da memória que fornece os indicadores básicos de um passado que produziu as circunstâncias do presente, sem a consciência das quais seria impossível ter ou elaborar projetos. [...] O projeto e a memória associam-se e articulam-se ao dar significado à vida e às ações dos indivíduos em outros termos, à própria identidade. (p. 101). 
Nessa perspectiva apontada pelo autor, considerei a atuação militante no movimento sindical docente como projeto de vida.

Para Velho (1994), a importância da trajetória individual emerge nas sociedades onde há predominância de ideologias individualistas:

Suas experiências pessoais, seus amores, desejos, sofrimentos, decepções, frustações, traumas, triunfos etc. são os marcos que indicam o sentido de sua singularidade enquanto indivíduo que é constantemente enfatizada. Carreira, biografia e trajetória constituem noções que fazem sentido a partir da eleição lenta e progressiva que transforma o indivíduo biológico em valor básico da sociedade ocidental moderna. (p. 100).

Certamente as trajetórias narradas pelos sujeitos da pesquisa não são lineares, elas são atravessadas por alegrias, dessabores, mudanças de rumo e retomadas, de acordo com as disposições construídas ao longo da vida, na origem familiar, na formação acadêmica, no exercício do trabalho e na participação em outros grupos sociais. A ideia é apreender nas diferentes trajetórias de vida de militantes do movimento sindical docente em Duque de Caxias, quais são as estruturas comuns que os impulsionaram à militância e que são construídas por ela.

$\mathrm{Na}$ primeira parte deste capítulo, faço uma breve apresentação dos entrevistados. Em seguida, relato a história dos encontros, descrevendo o contexto em que se deu cada entrevista. Por fim, abordo as trajetórias familiares dos professores, passando por questões como território, gênero e escolarização.

\section{1}

\section{Uma breve apresentação}

Em diferentes estágios da vida profissional e pessoal, esses professores e professoras têm em comum a militância na rede municipal de Duque de Caxias. Nessa seção, apresento cada um deles, a começar pelas razões e contextos de escolha dos depoentes e, em seguida, destaco suas origens familiares, passando pela infância, escolarização e construção de disposições políticas.

Por uma questão de ética e respeito aos participantes da pesquisa, preservo seu anonimato substituindo seus nomes por outros de natureza fictícia. Porém, por entender que o nome possui um lugar importante na identidade dos sujeitos, a escolha desse codinome foi feita de modo que guardassem alguma relação com suas histórias, com traços de sua personalidade ou militância. Portanto, busquei a 
inspiração em personalidades importantes no campo artístico, político e social cujas histórias me remetessem de algum modo aos entrevistados.

Os nomes: Armanda, Galeano, Cora, Tarsila, Nise, Mário, Rosa, Elis, Clarice, Dandara, Cecília, Olga, Francisca, Zilda e Frida foram inspirados, respectivamente, em Armanda Álvaro Alberto, educadora; Eduardo Galeano, escritor; Cora Coralina, poetisa; Tarsila do Amaral, pintora; Nise da Silveira, psiquiatra; Mário de Andrade, escritor; Rosa Luxemburgo, filósofa e economista marxista; Elis Regina, cantora; Clarice Lispector, escritora; Dandara dos Palmares, guerreira negra; Cecília Meireles, poetisa; Olga Benário, militante comunista; Francisca Edwiges Neves Gonzaga (Chiquinha Gonzaga), compositora; Zilda Arns, médica; e Frida Kahlo, pintora.

Por que escolhi cada um desses professores e professoras? De que lugar falam? Trago, a seguir, uma breve descrição de cada entrevistado(a), situando sua posição dentro do campo sindical, para mais adiante prosseguir com a análise de suas trajetórias de vida.

Armanda está na rede de Caxias há 5 anos. É da base da categoria ${ }^{21}$, foi membro do conselho de representantes e é desse lugar que é entrevistada. É professora da educação de jovens e adultos e trabalha no turno da noite. Durante a faculdade participou do movimento estudantil. Vem de uma família onde há uma forte atuação em movimentos sociais e na política.

Galeano é professor de geografia e membro da direção do Sepe, participa diretamente do movimento sindical há mais de 20 anos, tem se mostrado muito preocupado com a questão da formação política da categoria docente. É bastante articulado com o movimento estudantil, com a constituição de grêmios e conselhos escolares na busca de solidificar o projeto de gestão democrática, o qual sonha ver consolidado na rede municipal de Duque de Caxias.

Cora também é da direção do sindicato, mas há pouco tempo. Esse é seu primeiro mandato. É professora do $1^{\circ}$ segmento do ensino fundamental e também profissional da saúde. Ingressou no magistério público mais tardiamente, após uma longa trajetória de trabalho em uma empresa privada.

Tarsila é professora das séries iniciais e orientadora educacional, já está em seu segundo mandato na direção do sindicato. Filha de dirigente sindical da

\footnotetext{
${ }^{21}$ Não ocupa cargo de direção.
} 
categoria dos bancários, sua história é atravessada pela participação no movimento estudantil, e em pré-vestibular comunitário, o que de alguma forma, conforme ela afirmou, fez do movimento sindical "um caminho a ser seguido naturalmente".

Nise é orientadora educacional no município de Duque de Caxias e professora do curso Normal, no Estado. Diretora sindical desde os anos 1990, também milita ativamente pela alimentação escolar e movimento popular (federação municipal de associações de moradores de Duque de Caxias - MUB).

Mário é professor das séries iniciais e estudante de pedagogia. Está em seu primeiro mandato junto à direção do sindicato, na Secretaria de Gênero e Combate à Homofobia. Além de diretor sindical, milita contra a intolerância religiosa na cidade.

Rosa, professora da educação especial, cumpre seu terceiro mandato consecutivo como diretora sindical; também é liderança no movimento de mulheres e atua no movimento negro. Foi candidata a vereadora nas últimas eleições municipais, sendo ativa no núcleo do PSOL no município de Caxias.

Elis é professora da sala de recursos, membro do conselho de representantes. Além da atuação junto a sua escola, tem um histórico de participação nas demandas sociais do bairro onde cresceu e vive até hoje, Vila Canaã, $4^{\circ}$ Distrito do município de Caxias.

Clarice é orientadora educacional de uma escola cujo projeto educativo é referência para a cidade. Membro do atual colegiado que dirige o Sepe, sua atuação se divide entre escola e sindicato. Tem uma trajetória forte de participação na construção do Sepe/Caxias.

Dandara é membro da chapa minoritária que compõe o colegiado da direção do Sepe no município de Duque de Caxias; participa do Movimento Negro Quilombo Raça e Classe e é filiada militante do PSTU.

Cecília é professora das séries iniciais do ensino fundamental e orientadora pedagógica. Atua na rede municipal há quase 30 anos. Já participou da direção do Sepe/Caxias e hoje é bastante ativa na base sindical.

Olga é professora e orientadora educacional aposentada. Membro da direção colegiada do núcleo municipal de Duque de Caxias. Já esteve à frente do Sepe/RJ e participou da história de constituição desse sindicato. Possui também forte atuação no núcleo municipal do PSTU, pelo qual saiu candidata a prefeita da cidade nas últimas eleições. 
Francisca é professora de história, aposentada na rede estadual e municipal. Dada sua intensa atuação na militância, também se constituiu uma referência para o movimento sindical em Duque de Caxias. Foi candidata a diversos cargos eletivos ao longo de sua história.

Zilda foi professora de educação especial da rede estadual. Atuou em momentos históricos do sindicato, como na ampliação da filiação para os demais profissionais da educação e construção do plano de carreira do município.

Frida é professora aposentada, membro da atual direção no núcleo Sepe/Caxias, onde construiu sua trajetória de luta. Muito influente por sua história e carisma, destaca-se na intermediação das demandas da categoria junto ao governo.

Como mostra o Quadro 2, o grupo é composto de professores das séries iniciais do ensino fundamental, professores dos anos finais e orientadores pedagógicos e educacionais. Dez deles moradores de Duque de Caxias, três do Rio de Janeiro e duas de Niterói.

Quatro entrevistados são membros da base, e o restante compõe a direção colegiada do núcleo, pois de modo geral, a atuação dos diretores sindicais se destaca entre os demais militantes.

Do ponto de vista da idade, a composição do grupo entrevistado varia entre os 34 e 69 anos - muito embora a experiência sindical não acompanhe a ordem cronológica da idade. No capítulo 4 falarei mais sobre essas questões ao abordar as trajetórias sindicais. 


\begin{tabular}{|c|c|c|c|c|}
\hline & $\begin{array}{l}\text { Entrevistado } \\
\quad \text { (idade) }\end{array}$ & $\begin{array}{l}\text { Local de } \\
\text { moradia }\end{array}$ & $\begin{array}{l}\text { Ingresso e função docente em Duque } \\
\text { de Caxias }\end{array}$ & $\begin{array}{l}\text { Posição que } \\
\text { ocupa no } \\
\text { Sepe }\end{array}$ \\
\hline 1 & Armanda (34) & Duque de Caxias & $\begin{array}{l}2011 \text { - Professora das séries iniciais } \\
\text { (EJA) }\end{array}$ & Base $(\mathrm{CR})^{*}$ \\
\hline 2 & Galeano (48) & Duque de Caxias & 1991 - Professor de geografia & Direção \\
\hline 3 & Cora $(52)$ & Duque de Caxias & $\begin{array}{l}2004 \text { - Professora das séries iniciais } \\
\text { (ensino religioso) }\end{array}$ & Direção \\
\hline 4 & Tarsila (34) & Rio de Janeiro & $\begin{array}{l}2004-\text { Orientadora educacional e } \\
\text { professora das séries iniciais }\end{array}$ & Direção \\
\hline 5 & Nise (48) & Duque de Caxias & $\begin{array}{l}1990 \text { - Orientadora educacional e } \\
\text { professora do curso de Formação de } \\
\text { Professores }\end{array}$ & Direção \\
\hline 6 & Mário (38) & Duque de Caxias & 2007 - Professor das séries iniciais & Direção \\
\hline 7 & Rosa (43) & Duque de Caxias & $\begin{array}{l}1996 \text { - Professora das séries iniciais } \\
\text { (educação especial) }\end{array}$ & Direção \\
\hline 8 & Elis (53) & Duque de Caxias & $\begin{array}{l}2004 \text { - Professora das séries iniciais } \\
\text { (atendimento educacional especializado) }\end{array}$ & Base $(\mathrm{CR})^{*}$ \\
\hline 9 & Clarice (51) & Duque de Caxias & $\begin{array}{l}1987 \text { - Orientadora educacional e } \\
\text { professora do curso de Formação de } \\
\text { Professores }\end{array}$ & Direção \\
\hline 10 & Dandara (52) & Rio de Janeiro & 1996 - Professora das séries iniciais & Direção \\
\hline 11 & Cecília (49) & Duque de Caxias & $\begin{array}{l}1991-\text { Orientadora pedagógica e } \\
\text { professora das séries iniciais }\end{array}$ & Base \\
\hline 12 & Olga (67) & Duque de Caxias & $\begin{array}{l}\text { 1970/74 - Orientadora educacional e } \\
\text { professora do ensino fundamental }\end{array}$ & Direção \\
\hline 13 & Zilda (54) & Rio de Janeiro & $\begin{array}{l}1985 \text { - Professora de educação especial e } \\
\text { pedagoga da secretaria de Ação Social }\end{array}$ & Ex-direção \\
\hline 14 & Francisca (69) & Niterói & $\begin{array}{l}1970 / 80-\text { Professora de História } \\
\text { (aposentada) }\end{array}$ & Base \\
\hline 15 & Frida (56) & Niterói & 1988 - Professora das séries iniciais & Direção \\
\hline
\end{tabular}

Quadro 2 - Informações básicas sobre os entrevistados

Fonte: Elaboração própria.

Com essa breve apresentação, busquei situar o leitor sobre quem foram os entrevistados e entrevistadas desta pesquisa. A seguir, discorro sobre o processo de escolha e contato com cada um deles.

\section{2}

\section{A história dos encontros ou uma história de encontros}

O trabalho com história de vida requer do pesquisador uma atenção especial na escolha dos sujeitos, sua chegada até eles, o contexto no qual se dá a entrevista, ambiente onde é realizada e, principalmente, sensibilidade aos detalhes que dizem respeito ao estado de espírito do entrevistado, sua personalidade e abertura para falar de sua trajetória. Sem isso, é arriscado que se caia em uma ação mecânica de 
leitura e resposta a questões pré-determinadas, sem que se penetre na complexidade das histórias da vida real.

A exemplo de Lelis (1996), trago o relato dos encontros com cada professor entrevistado, entendendo a importância do momento em que se passou o diálogo entre pesquisador/entrevistado, pois todo o percurso até sua realização é significativo. Além disso, acredito ser impossível separar o sujeito do contexto em que o cerca.

A abertura e as dificuldades para a marcação das entrevistas dizem respeito não apenas à sensibilidade dos indivíduos à participação na pesquisa, mas falam da situação em que um grupo profissional vive; do momento político que a instituição sindical docente atravessa; e das demandas diárias as quais os sujeitos estão submetidos na atualidade.

Assim, passo a relatar porque escolhi e como encontrei cada um dos professores entrevistados.

Armanda era membro atuante do conselho de representantes, em minhas observações já tinha notado sua assiduidade e participação nas ações sindicais. No entanto, ainda não havia tido a oportunidade de dialogar com ela, até que a encontrei em um curso de extensão sobre Educação de Jovens e Adultos, oferecido pela Universidade Federal do Rio de Janeiro (UFRJ) nas férias de 2016. Foi então que, ao conversarmos durante os intervalos do curso sobre práticas pedagógicas, sobre o sindicato, pesquisa e vida em geral, percebi que Armanda estava dentro do perfil que eu vinha delineando na pesquisa ${ }^{22}$. Ainda não tínhamos iniciado as discussões da data-base daquele ano, quando agendei um encontro na casa dela para que me concedesse a entrevista.

Residente no centro da cidade Duque de Caxias, o encontro aconteceu na parte da tarde. A entrevista ocorreu no quarto do seu filho, enquanto ele estava na escola; a ideia era que pudéssemos ter um ambiente silencioso para que as falas fossem gravadas. Ainda assim, o silêncio ficou prejudicado pela proximidade a uma escola de educação infantil, localizada ao lado da casa. Na gravação, as vozes de professoras e alunos aparecem ao fundo, mas nada que atrapalhe a fruição de Armanda - bastante habituada ao burburinho ao lado - na resposta às questões com muita calma e riqueza de detalhes. O tempo voou, e entre duas pequenas interrupções por celular, o encontro levou $2 \mathrm{~h} 30 \mathrm{~min}$, até que chegou o momento de Armanda buscar seu filho na escola. (Diário de campo, 07/03/2016).

\footnotetext{
${ }^{22}$ Esse perfil, bem como seu processo de construção, foi descrito no capítulo anterior.
} 
Saí bastante animada desse encontro, na certeza de que a entrevista havia sido um sucesso e que logo em seguida passaria a entrevistar os dirigentes sindicais. No entanto, até aquele momento eu não sabia o que estaria por vir: um período nebuloso de parcelamentos e adiamentos de salários que se arrastaria ao longo do ano de $2016^{23}$ evocando uma ação sindical mais combativa a qual me impediria de ter dos demais membros do sindicato a mesma atenção dispensada por Armanda.

Só em janeiro de 2017, com a mudança de governo, foi possível retomar as entrevistas. Após esse período, o primeiro com quem me encontrei foi Galeano, dirigente sindical experiente e professor de geografia. Nosso encontro ocorreu durante seu plantão de férias, na sede ${ }^{24}$ do sindicato que fica no centro de Duque de Caxias.

No auditório da sede, onde fizemos a entrevista, o cenário remetia a uma passagem de ano sofrida para os servidores. Lembrando o fim de uma guerra ou de um vendaval, havia bolsas e embalagens de produtos por todos os lados - itens de uma cesta básica oferecida aos profissionais da educação que se viram em situação de privação em meio as festas de fim de ano, após um atraso cumulativo de três folhas de pagamento.

A entrevista, agendada ainda no ano anterior, foi interrompida algumas vezes pelos funcionários do sindicato ao pegarem cestas para alguns profissionais que ainda se encontravam necessitados, e para chamar Galeano ao telefone para resolver problemas que vinham da Secretaria de Educação, pois nesse mesmo dia, enquanto conversávamos, a secretaria enviou um ofício às escolas cobrando a reposição dos dias parados em 2016, ignorando toda a negociação feita com os gestores anteriores ao término do ano letivo.

Tudo isso demonstra um pouco do período de instabilidade em que decorreriam as demais entrevistas, ao final das quais sempre procurei fazer um relato no diário de campo:

A entrevista foi marcada para $14 \mathrm{~h}$, na sede do sindicato. O primeiro contato já havia sido feito pessoalmente na última assembleia, agendamos para o dia do plantão do Galeano durante as férias e confirmamos a agenda por WhatsApp. Debaixo de um tremendo sol de $40^{\circ}$, cheguei um pouco antes do horário e o Galeano já estava por

\footnotetext{
${ }^{23}$ Ao longo do ano de 2017, os atrasos de salário perduraram, porém, a intensidade das ações na rua diminuiu em relação ao ano anterior.

${ }^{24}$ A sede do núcleo sindical, de acordo com a descrição de uma professora, "uma casinha verdinha aconchegante no coração da 25", foi o palco de vários encontros e observações realizadas nesta pesquisa. No croqui, apresentado no Apêndice C, é possível observar sua disposição interna e as salas na qual realizei a maior parte das entrevistas.
} 
lá, atendendo um telefonema. O clima no município estava muito agitado em virtude da promessa de pagamento, até então não cumprida. A entrevista se realizou na sala de reuniões, em meio a grande bagunça de bolsas de mantimentos proveniente de doações que estavam sendo arrecadadas e distribuídas aos professores em dificuldade devido ao atraso de mais de três folhas de pagamento. $\mathrm{O}$ ar-condicionado da sala não dava vazão ao tamanho calor que fazia, especialmente porque de vez em quando o funcionário do sindicato ou mais alguém necessitava entrar para mexer nas cestas. A primeira parte da entrevista fluiu muito bem, várias perguntas do meu roteiro foram sendo respondidas sem que eu nem mesmo necessitasse perguntar. Galeano parecia à vontade, e ansioso para falar da questão da formação, assunto que perceptivelmente é muito caro a ele. Duas interrupções foram feitas, até que na segunda ele precisou se retirar da sala, quando voltou, parecia preocupado, passou a responder as questões de forma mais rápida. Eu o perguntei se não queria findar por ali, e marcar um outro dia, mas ele disse que preferia responder logo. Então encurtei as perguntas e finalizei o quanto antes, pois elas já não tinham o efeito anterior. Apesar dessa correria do final, a primeira parte foi realmente muito boa. Ele repetiu muito do que costuma falar em conselhos e assembleias, mas de forma mais refletida e calma. Outra coisa que é bom ressaltar, é que em sua fala, ele priorizou a reflexão sobre o sindicato, sobre o coletivo, e não se deixou levar muito para a questão da sua história de vida. Tirando a primeira resposta, suas análises se voltam mais ao espaço sindical e a si como sindicalista que como professor propriamente dito. (Diário de Campo, 10/01/2017).

Em fevereiro, em lugar do primeiro dia letivo, o ano se iniciou com uma assembleia, na qual se discutiu o retorno ou não às aulas diante da falta de pagamentos. Foram cinco dias de paralisações até que se negociou com o novo prefeito, Washington Reis (PMDB), um calendário de pagamento. Os meses de novembro e dezembro só seriam pagos ao fim de abril e junho, respectivamente. A aceitação dessa proposta pela assembleia ocasionou grande debate e divisão entre os que queriam lutar, em greve, pelo pagamento imediato dos atrasados e a maioria que votou a favor dessa negociação e início das aulas.

Nesse contexto de críticas ao sindicato, encontrei as diretoras Cora e Tarsila, ambas menos experientes que Galeano na direção sindical. Mas cada qual com diferentes trajetórias de vida e de militância. Os encontros ocorreram também em seus plantões na sede, por preferência das duas. Apesar de ter oferecido ir às suas residências, acredito que a possibilidade de dispor do dia do plantão para me receber seja uma forma de aproveitar melhor o tempo assoberbado da direção sindical.

Bastante agitada, e sempre muito envolvida com as tarefas da nova posição de membro da direção no sindicato, a qual concilia com outro emprego na área da saúde, Cora, ao ser convidada para a entrevista, não acreditou que pudesse contribuir com a pesquisa, pois, segundo ela, tinha pouco a contar. Essa modéstia inicial contrastou com a beleza da trajetória revelada no depoimento emocionado de quem superou muitas dificuldades para chegar onde chegou. Do ponto de vista 
humano, essa entrevista despertou em mim a necessidade de deitar um olhar mais atento ao papel das emoções nos relatos de vida.

Hoje finalmente consegui fazer a entrevista com a Cora. Não querendo ultrapassar a linha tênue entre mostrar o interesse e forçar uma "barra", consegui me mostrar disponível suficiente para driblar a vida corrida de minha entrevistada. Uma pessoa visivelmente "ligada em 220", que vive um contexto de muitas demandas. Mas algumas conversas anteriores e uma intuição de pesquisadora (em desenvolvimento) me fez insistir na possibilidade da entrevista. E valeu a pena! Uma história linda, de muita perseverança e luta. Cora não é uma mulher da política, não é dirigente sindical há anos... Cora é uma pessoa de muita garra, que correu atrás a vida toda com muita força e insistência, lutando contra as circunstâncias adversas, primeiro da morte do pai, depois de um marido alcoólatra. Assim, se constituiu professora e só posteriormente sindicalista. E eu que achava que nas histórias de vida dos meus entrevistados era o sindicato que iria "mudar tudo na vida dessas pessoas", que ilusão! É a vida dessas pessoas quem muda o sindicato e dá sentido à luta. (Diário de Campo, 27/01/2017).

A marcação da entrevista com a Tarsila foi bastante condizente com o que já tinha observado de sua atuação muito prestativa. Durante o ano de 2016, as ações de Tarsila foram bastante apreciadas por vários membros da base do sindicato, pela solicitude e atenção. Ela demonstrou sobriedade no trato das questões que se apresentaram ao longo de um ano turbulento, de vários embates com o governo. Assim, logo no primeiro contato se prontificou em me atender na semana seguinte, na sede do sindicato.

Já o agendamento da entrevista com Nise foi dificultado pelo fato de estar "pagando" 5 meses de greve no Estado, onde trabalha com formação de professores no antigo curso Normal. O "pagamento" da greve estava deixando-a muito cansada, especialmente por ser professora de estágio supervisionado, uma disciplina que, segundo ela, "exige o acompanhamento dia a dia". Ao longo dos três primeiros meses do ano, fiz quatro contatos com Nise: dois telefônicos e dois pessoalmente, durante atividades do núcleo sindical, em todos eles seu cansaço estava aparente. Como ela havia demonstrado interesse em participar, persisti por compreender a importância de sua história para o movimento sindical na cidade, mas tentei não ser inconveniente, respeitando o tempo que achou necessário para a marcação da entrevista. Segue um dos registros no meu diário sobre esses contatos:

Fiz o segundo contato com a Nise, na tentativa de marcar uma entrevista. Ela logo atendeu o telefone, estava em horário de intervalo, mas tinha a voz um pouco tensa. 
Eu pensei que o adiamento das aulas na rede municipa ${ }^{25}$ seria uma boa oportunidade para conseguir um tempo mais tranquilo em sua agenda, mas ao invés de ajudar esse adiamento atrapalhou, pois Nise é professora de estágio do curso Normal, e seus alunos dependem do município para realizar seus estágios. Agora, ela além de estar fazendo a reposição do ano anterior, está às voltas para passar esse estágio para a rede privada. Por isso, pediu que eu retornasse na próxima segunda, quando espera que já tenha conseguido reorganizar o estágio de seus alunos. (Diário de Campo, 02/02/2017).

Após todo o "pagamento de greve" nos meses de janeiro e fevereiro, em uma conversa durante a assembleia conseguimos finalmente agendar uma data. Nise estava doente, sentindo dores no corpo inteiro, muito provavelmente em decorrência do estresse com o trabalho. Ainda assim, decidiu marcar a entrevista para a semana seguinte e cogitava ir ao ato de Greve Nacional da Educação na capital do Rio, para o qual o núcleo de Caxias havia fretado dois ônibus para levar seus filiados. Percebendo sua condição, eu mesma a desaconselhei, dizendo que cuidasse de sua saúde, pois certamente a luta não pararia por ali e ela poderia participar de outros atos iguais.

Nosso encontro mais uma vez corroborou a sensação de sobrecarga que vi em Nise já em nosso primeiro diálogo. Ao chegar à sede, recebi o recado de que ela estava atendendo uma escola e que iria se atrasar. Junto com outra diretora, chegou esbaforida, pálida e me agradeceu tê-la esperado. Começou acelerada, mas aos poucos foi relaxando. Ao final, sua expressão: “Já acabou? Jura?”, indicou o prazer que ela teve ao relatar sua história de vida, que de fato é muito bonita.

Estive hoje com Nise para fazer a entrevista. Nosso encontro estava marcado para $16 \mathrm{~h}$, e ela só chegou às $17 \mathrm{~h}$. Vinha de uma creche, com outra diretora, onde estava resolvendo um "chamado". Ela disse como é difícil organizar o tempo, pois os chamados às vezes pedem certos desdobramentos cujo tempo não pode ser mensurado. Esse atraso, por essa razão, de certa forma foi muito compatível com o relato de vida de Nise. Ela literalmente "vive para o sindicato" e não só para ele como também para o MUB e outros espaços de militância. Nise adiou projetos pessoais em função do sindicato. Quando se sentou para me atender, estava com pão e café na mão, demonstração de uma vida tão corrida, que muitas vezes passa pela supressão da alimentação, razão pela qual acredito que esteja se sentindo doente agora. Ao iniciarmos a conversa, e antes que eu ligasse o gravador, ela pediu que eu adiantasse sobre o que ela deveria falar, demonstrando uma preocupação com respostas "certas" e "erradas". Eu the expliquei os objetivos da pesquisa e disse que não se preocupasse, pois se tratava de sua história e do sindicato apenas, e que não havia questões constrangedoras ou pegadinhas. No início da conversa ela parecia acelerada, mas no decorrer da entrevista foi se soltando e se acalmando. Ficou emocionada em algumas partes da entrevista, chegando a avermelhar os olhos e

\footnotetext{
${ }^{25}$ No ano de 2017, o calendário letivo foi atrasado em uma semana por parte da SME que alegou problemas com o contrato das firmas terceirizadas responsáveis pela limpeza das unidades escolares do município.
} 
esboçar expressão de choro ao falar da "passagem de seu pai", de conflitos na escola e no sindicato. Algumas vezes sorriu, ficou constrangida ao mencionar alguns relacionamentos amorosos, e se enrijeceu ao proferir críticas a alguns colegas da rede que não possuem compromisso com a educação. Muitas vezes, apontou trechos que não gostaria de ter publicados. E quando eu desliguei o gravador, se pôs a falar de coisas que não gostaria que fossem gravadas [...]. (Diário de Campo, 21/02/2017).

Em seu livro, “A entrevista compreensiva”, Kaufmann (2013) fala sobre essa mudança ao longo do relato, que se inicia tenso, e vai ficando solto, ao longo da entrevista, pela "vontade de falar de si":

Entre as portas que se fecham e as primeiras respostas secas, os contatos iniciais das entrevistas nem sempre são fáceis. Felizmente, é frequente que o entrevistador não tenha mais que se esforçar no decorrer da entrevista: o informante tem vontade de falar por conta própria. Ele entrou em sua biografia, e viaja guiado pelo entrevistador em torno de um tema; e tomou gosto pela viagem. Fala de si e nós o escutamos, desenvolve seus argumentos e suas opiniões tem relevância. Fala de si e verifica sua capacidade em ser dotado de uma identidade claramente identificável e digna de interesse. [...] Até ao ponto em que o entrevistador e a entrevista chegam a ser esquecidos, apesar de seu caráter pouco comum, pela vontade de falar de si. De falar de si, para uma espécie de mundo anônimo, sem deixar de falar de si mesmo. (KAUFMANN, 2013, p. 102).

A chegada a Mário foi completamente diferente de Nise. Antes de ter consultada sua disponibilidade para ser entrevistado, ele mesmo deu sinais de que gostaria de ajudar na pesquisa com as seguintes perguntas: "Mas, quem você quer entrevistar? Tem que ser antigo?" - ao ver-me abordando uma das diretoras mais antigas do núcleo, Clarice. Aproveitei a "deixa" para explicar quais eram os objetivos daquela etapa da pesquisa, e que ele também poderia contribuir contando sua trajetória de vida junto ao núcleo sindical. Nesse mesmo dia, agendamos a entrevista para a semana seguinte, dois dias após a entrevista com Nise.

O encontro aconteceu no sindicato, no dia do plantão de Mário. Ao chegar na sede, encontrei-o agitado com algumas publicações conflituosas que haviam sido feitas nas redes sociais sobre a prestação de contas do núcleo sindical de Duque de Caxias. O funcionário que o acompanhava, cujo nome havia sido citado na postagem, puxou-me inesperadamente pelo braço em direção ao arquivo dizendo: "Você já é de casa, vem ver que o meu trabalho está tudo certinho" - e me mostrou uma série de balancetes contábeis com os registros de entradas e saídas dos recursos do sindicato. Ele queria que eu atestasse a correção de seu serviço, sobre o qual levantaram dúvidas, e parecia muito incomodado com essas questões. Acredito que minha presença constante no núcleo o fez se sentir à vontade para o desabafo. Enquanto isso, Mário tentava contornar a situação virtualmente, usando seu 
smartphone. Essa foi uma situação inusitada, mas que não atrapalhou o desenvolvimento da entrevista, logo que Mário e o funcionário se acalmaram.

Muito articulado, mas comedido, Mário fez seu relato se policiando a responder objetivamente sobre o que eu lhe perguntava, diferente de Nise que falou mais espontaneamente. Com ele precisei explorar algumas questões em cada eixo, estimulando-o a falar. Essa prudência ao se pronunciar parece ser fruto de sua recente vivência na direção sindical, como ele mesmo colocou em seu relato a respeito da responsabilidade adquirida ao se tornar um representante sindical, o reflexo do sentimento de "falar por outras pessoas".

Cheguei ao sindicato na hora exata que foi marcada a entrevista, 14h. Mário estava atordoado por conta de comentários conflituosos no grupo dos conselheiros de representantes no WhatsApp. [...] Após o desabafo, de Mário e do funcionário envolvido na história, retornamos à sala, e nossa conversa foi iniciada às $14 \mathrm{~h} 40 \mathrm{~min}$, transcorrendo tranquilamente, porém tive a mesma sensação que tive com a Tarsila, um comedimento nas respostas e a necessidade de fazer quase todas as perguntas do roteiro. Curioso, porque imaginei que seria mais fluido e que o tema da homossexualidade, por exemplo, emergiria com mais facilidade devido a sua militância, mas isso não ocorreu. Não sei se é uma questão de experiência, pois Tarsila e Mário são mais novos na direção e na idade, que Galeano e Nise, com os quais o relato fluiu sem muita necessidade de condução. (Diário de Campo, 23/03/2017).

O encontro com Rosa aconteceu depois de muitas tentativas de agendamento.

Ela foi uma das primeiras a quem contatei, pela sua presença marcante no atual movimento sindical docente em Duque de Caxias. Sempre preside a mesa de condução das assembleias e conselho, quase sempre está presente nas audiências de negociação com o governo, além de ter uma forte atuação em outros movimentos sociais e partido político. Ou seja, é uma pessoa demasiadamente ativa. E essa mesma característica que a tornava importante para a pesquisa, também a impedia de ter tempo para participar. Tentamos agendar um encontro várias vezes, e no auge de sua campanha para vereadora, ela chegou a me sugerir que fizéssemos a entrevista via mensagem, sendo obviamente, inviável. Passado todo o período eleitoral e também amenizadas as circunstâncias políticas adversas no município, conseguimos agendar um encontro após a primeira assembleia de abril.

Ao entrar na sala, logo percebi que havia fotografias penduradas em varais espalhados por toda parte, de modo a circundar a mesa onde sentamos. Fotos de ontem e hoje, remetiam a um longo percurso de luta e amizade construído no sindicato. Rosa me explicou que o mural foi feito pelos funcionários do Sepe em comemoração ao dia internacional das mulheres. Eles resgataram fotos de greves, passeatas, assembleias antigas e mais recentes onde as mulheres que compõem a direção estavam retratadas... Iniciada a entrevista, de cara, a primeira pergunta já foi 
respondida de uma forma bastante impactante. Eu pedi que ela falasse das suas origens familiares e ela descreveu suas raízes sociais humildes, explicitando a profissão de seus pais: costureira e sapateiro, separados, tendo a mãe criado os filhos sozinha. A força de suas palavras é reforçada pelo tom da sua voz. Rosa tem voz firme, decidida e não titubeia nas respostas. É muito articulada, e em todas as respostas parece dialogar com as impressões que tem sobre o que eu penso, sobre o que o senso comum pensa, e sobre o que é propagado a respeito do sindicato. (Diário de campo, 04/04/2017).

O clima de comemoração pela passagem do dia internacional da mulher retrata as alterações no cenário em relação ao do início do ano, quando as entrevistas foram feitas em meio a cestas de doações. Contudo, naquele momento ainda estavam atrasadas as folhas de pagamento de novembro e dezembro de 2016, trazendo reflexos para o movimento sindical e para a vida dos seus membros.

Quanto a Elis, observando sua atuação constante ao representar sua escola no conselho e sua participação ativa nas ações da data-base de 2016, correndo escolas, participando de audiências, mediando conflitos, percebi que ela seria uma pessoa a ser entrevistada. Ao fazer o convite, ela logo se prontificou a me receber em sua casa, em Vila Canaã, $4^{\circ}$ Distrito de Duque de Caxias. Mas, diferente do que eu imaginava, na entrevista Elis se mostrou inibida pelo gravador e não se expressou com a naturalidade que costuma ter em suas falas nos conselhos de representantes ou quando havíamos conversado em outros momentos, como neste, relatado em meu diário de campo:

Após o CR, descemos juntas para almoçar no restaurante em frente à universidade $\mathrm{e}$ lá encontramos Olga. [...] desencadeadas pela história de uma amiga em comum, Elis e Olga começaram a resgatar a história do sindicalismo em Caxias todinha... Sabe, um assunto puxa outro... Relembraram a juventude... E aí desembocou na história da primeira greve, na participação feminina na militância, no intercâmbio de movimentos e engajamentos de diversos participantes do sindicato hoje... Enfim! Que vontade de ligar o gravador! Quase pedi para ligar... As duas ficaram lá falando horas e eu só me deliciando com a história contada "por dentro", pelos olhos de quem dela participou. A história dos bastidores e a trajetória de vida das duas que falavam sem parar. Um dos temas interessantes da conversa foi o cotidiano familiar de uma militante [Elis] com um "pelego"26, o afastamento da militância em função da maternidade e as crises, na atualidade, em virtude de uma retomada dessa experiência. "Olha, eu estou voltando!" - conta Elis sobre quando, agora com a filha criada, diz ao marido que vai retomar sua atuação junto aos movimentos sociais da cidade. (Diário de campo, 10/03/2017).

\footnotetext{
${ }^{26}$ Designação pejorativa daqueles que são indiferentes ao movimento sindical, ou que "furam" greves.
} 
Clarice é uma pessoa importante na história do Sepe/Caxias, diretora sindical por vários mandatos, exerce grande influência na rede, não apenas por sua militância, mas por sua atuação pedagógica junto à E. M. Barro Branco ${ }^{27}$.

Bastante envolvida, inclusive emocionalmente, com as dificuldades enfrentadas pelo sindicato nas lutas travadas no ano 2016, não foi possível entrevistá-la nesse período, somente após a situação se acalmar um pouco, consegui agendar o encontro com ela.

Em contatos diretos e virtuais, tentamos algumas vezes esboçar uma agenda, mas apenas no dia da Greve Geral, ao retornar para Caxias, em ônibus fretado pelo sindicato, após a manifestação na Central do Brasil é que conseguimos chegar a data de 10 de abril, data distante, visto que estávamos em 15 de março, mas que aguardei pacientemente, por ser a data possível para ela.

O encontro ocorreu na E. M. Barro Branco, onde fui muito bem recebida pelos demais professores, especialmente a professora da sala de leitura, onde fiquei aguardando a chegada de Clarice, que estava "presa" no recadastramento ${ }^{28}$. Ao término da entrevista, fui convidada a permanecer no turno da noite, onde haveria um grupo de estudos.

Eu estava na sala de leitura observando a aula do quinto ano quando Clarice chegou para me chamar. Ela procurava uma sala vazia com ar para me atender, mas não tinha, então perguntou se poderíamos ter uma terceira pessoa junto, pois faríamos na sala da equipe pedagógica e a outra orientadora estava lá. Eu disse que não haveria problemas e ao longo da entrevista, achei até interessante, pois como antiga na rede e militante, ela fez várias contribuições. Primeiro me mostraram a sala, os armários com arquivos de 10 anos de trabalho e estante de livros organizadíssimos. Clarice se sentou em uma poltrona verde, e apoiando os pés em uma das cadeiras quase se deitou. Alguns momentos, pareceu um divã. Enquanto eu entrevistava Clarice, a orientadora permaneceu sentada lendo e separando relatórios. Vez por outra, alguém entrava na sala, alguns viam que estávamos gravando e saíam, outros falavam com a Clarice mesmo assim. Foi necessário que eu pausasse a gravação algumas vezes. Mas, de modo geral, a entrevista correu bem. Com certa antecipação de perguntas por medo de perder algum lance, cheguei a ser redundante ao seguir o roteiro quase que à risca. Nesses momentos, Clarice falava: "como eu já comentei", "isso eu acho que já te disse"... De toda forma, a conversa foi boa, ela realmente é uma referência, e mesmo sem ser arrogante, deixa claro que tem consciência de sua importância para a história do sindicato. Aquele aspecto de "negação de si mesmo" que eu já tinha observado nos mais antigos, especialmente em Nise, também foi observado na trajetória de Clarice. Queria encontrar uma palavra mais adequada para isso, mas no

\footnotetext{
${ }^{27}$ Para conhecer mais do projeto pedagógico desenvolvido por essa escola ler: Alcântara (2016).

${ }^{28}$ Logo após as eleições, uma das primeiras iniciativas do prefeito eleito foi a fixação de um calendário de recadastramento, com registro das digitais e íris de todos os servidores para fins de instalação do ponto eletrônico.
} 
momento, acho que o termo que posso usar é "entrega". (Diário de campo, 10/04/2017).

O agendamento com Dandara ocorreu em um conselho de representantes e o encontro se realizou na sede do sindicato. Eu vinha observando a atuação constante e divergente de Dandara há algum tempo. Durante um ato na porta da prefeitura já havíamos conversado um pouco sobre sua história, o que me interessou bastante, especialmente por ser uma representante da chapa minoritária que compõe a direção colegiada. É importante ter a diversidade dentro do conjunto de entrevistados, um outro ponto de vista. Ao ser convidada a dar uma entrevista, ela demonstrou bastante alegria e interesse, marcando a data logo para a semana seguinte. Ao conhecer um pouco de sua história, entendi que para ela a questão de ser ouvida e ter sua palavra levada em consideração é algo de extrema importância, justamente pela sua condição de minoria dentro do colegiado.

Ontem fui ao Sepe entrevistar a Dandara. Chegando lá, como de costume, sentei na recepção para aguardar. Chega Nise, me abraça, me beija e me pergunta se vou entrevistar mais alguém, eu digo "Dandara", ela sorri, ironicamente, demonstrando certa rivalidade para com a colega de direção. Iniciamos a entrevista e lá pelo meio ela me perguntou se tudo será transposto na íntegra, eu digo que analisarei o todo e só usarei fragmentos de sua fala, mas que a entrevista será transcrita e que eu lhe apresentarei o texto integral, caso queira fazer algum corte. Também reafirmo que lhe será garantido o anonimato. Ela esteve bem à vontade durante toda a entrevista. Alguns temas ela desenvolveu com mais detalhes, como sua história pessoal e algumas críticas à direção majoritária do sindicato; emocionou-se ao falar de sua avó, que mesmo analfabeta lhe educou, inclusive cobrando os deveres de casa. Também foi bastante forte seu relato sobre as relações dentro do núcleo. Ela se alegrou ao falar de certo reconhecimento da categoria ao votar em sua chapa que era composta em sua maioria por professores da rede estadual e aposentados; e dos colegas mais novos da direção que dão atenção às suas falas. A questão da linguagem e do encadeamento do pensamento foi apresentada como dificuldade decorrente da pressão vivida dentro do sindicato, especialmente em gestões anteriores. Mas, a percepção do autodesenvolvimento nessa e em outras áreas, é atribuído à persistência em "não deixar de falar, ainda que sendo oprimida". (Diário de Campo, 12/04/2017).

Cecília foi observada pelas falas e frequências constantes em assembleia. Ela não faz parte do conselho de representantes, embora frequente o grupo esporadicamente e mencione sempre as questões de sua escola. O contato com ela se deu mediante a participação em um pequeno grupo virtual composto por diretoras sindicais e membros da base, criado para organizar encontros de formação para professores especialistas (orientadores pedagógicos e educacionais) da rede.

Conforme agendado há uma semana, hoje realizei a entrevista com a professora e orientadora pedagógica Cecília. O encontro foi realizado na sede do sindicato, na "sala de trás". A entrevista fluiu muito bem, durou cerca de 2 horas, acho que foi a 
mais longa que já fiz até agora. A questão da prática apareceu muito mais e com bastante força, de forma natural, sem que para isso eu precisasse fazer muitas perguntas. Também a questão da formação no espaço sindical, acho que Cecília explicou com clareza justamente o que é também a minha tese: "o sindicato é um espaço formativo, para além da docência, para a vida. E o que você aprende nesse espaço, você leva para a vida, contagia outras pessoas à medida que você é contagiado". Nas palavras de Cecília, sente-se a firmeza de quem passou por esse espaço, fez e faz dele um lugar de aprendizagem, de aprimoramento. Ela tem um jeito muito enfático de se expressar, gesticulando, afirmando com as mãos em cone batendo na mesa. Seu tom de voz é bastante agudo e se eleva ao tratar de questões que a movem, como falar de discordâncias sobre determinadas posturas de companheiros que militam em prol dos seus direitos, mas se esquecem de lutar pelo direito dos alunos. Uma entrevista muito boa, mas muito cansativa intelectualmente, parece que me sugou... Eu tentava a todo tempo mostrar minha atenção, estimulando Cecília a falar pela demonstração de interesse em sua narrativa, sem, contudo, fazer grandes intervenções verbais que tolhessem ou atrapalhasse sua linha de raciocínio. Tentei sintetizar em poucas questões o que eu gostaria de saber, dando margem para que ela falasse com profundidade sem que fosse interrompida desnecessariamente. (Diário de campo, 04/05/2017).

Olga faz parte do conjunto de atores referência para o sindicalismo em Duque de Caxias. Membro da chapa minoritária que compõe o colegiado de diretores do

núcleo, ela está aposentada, mas é bastante ativa na militância. Quando solicitei a entrevista ela se posicionou reticente, pois teve uma experiência frustrante em um momento anterior. Ainda assim, por ter desejo de ver seus relatos sobre a militância docente registrados, aceitou o convite.

Hoje entrevistei Olga. Marcamos 16h na FEBF, onde estaria acontecendo o CR desde às $13 \mathrm{~h}$. Nosso encontro foi marcado anteriormente ao conselho, mas com a continuidade da greve, achei que poderia vir a ser desmarcado, tendo em vista o envolvimento de Olga não apenas com o Sepe/Caxias, mas também com o Sepe/Rio e outras lutas sindicais de outras categorias, as quais ela tem por princípio apoiar. Acompanhei o CR sentada na frente como de costume, perto das 16h horas fui para a porta do auditório à espera da chegada de Olga, sabendo que se ela entrasse seria difícil sua saída, dado o seu envolvimento com as questões que vinham sendo debatidas ali. Tão logo ela chegou, fui ao seu encontro e busquei uma sala vazia para que fizéssemos a entrevista. Olga, como sempre, estava muito bem vestida, blusa de seda, colar e diadema vermelho na cabeça. Em seu dedo um anel de pedra preta, lembrando a formatura em educação. Bastante delicada no falar, Olga sinalizou estar se sentido mexida, pois "revolver tudo isso não é fácil", tem preocupações com a história do sindicato, com a sua história de vida... Ela disse que já havia ocorrido algumas tentativas de escrever a história do sindicalismo em Caxias, mas todas frustradas. (Diário de campo, 19/06/2017).

O encontro com Zilda ocorreu por indicação de Clarice, que apontou a exdiretora como alguém importante no processo de construção do núcleo sindical do Sepe em Duque de Caxias. Embora hoje não atue mais junto ao núcleo Sepe/Caxias, Zilda se dispôs a participar com bastante abertura. 
Marquei a entrevista com Zilda no Sepe, mas como ela só pode chegar às 17h30, não foi possível fazer na sede. Então, seguimos para uma confeitaria próxima, mas estava tão tumultuado que decidimos nos dirigir ao bar ao lado que estava bem mais vazio. Zilda tinha uma visível dificuldade de locomoção por conta de um problema de articulação, inclusive veio direto de uma consulta médica. Tentei evitar transtornos à entrevistada, mudando mais uma vez de local, mas no decorrer da entrevista fiquei preocupada com a música ao fundo por causa da gravação. Quanto à entrevista em si, correu tranquilamente. Zilda é bastante articulada, e por isso não foi preciso que eu fizesse muitas intervenções para além do esclarecimento inicial dos objetivos da entrevista. Ao final da entrevista, tocou em questões mais pessoais, como a relação entre maternidade e militância sindical. Apesar do transtorno inicial, o encontro foi bastante proveitoso. (Diário de Campo, 24/07/2017).

A decisão de entrevistar Francisca veio mediante os relatos de militantes da base e da direção sobre sua trajetória no sindicato. Durante muitos anos, ela fez parte da direção colegiada do Sepe/Caxias, passando também pela direção do Sepe/RJ. Hoje, aposentada, não está mais na direção sindical, embora ainda seja muito considerada por sua dedicação à militância. Muito aberta a falar sobre o sindicalismo, foi solícita ao agendar a entrevista, fazendo questão de vir de sua casa em Niterói até Duque de Caxias para conversarmos na sede do Sepe, onde havia arquivado uma série de registros que quis me mostrar com a ajuda de sua amiga, também aposentada, Frida.

No transcurso da entrevista, tudo correu bem. Tentei seguir os conselhos de Bosi, respeitando o tempo da memória de Francisca, e intervindo o mínimo possível. Em alguns momentos ela esquecia as datas, mas apontava para os jornais dizendo que poderia procurar depois ali ou recorrer a Frida, cuja "a memória é melhor", segundo ela. Alguns brancos e "perda de fios da meada" também ocorreram. Algumas vezes foi pedido para que a gravação fosse interrompida, para falar de coisas que ela não queria que ficassem registradas - entrevista é uma relação de confiança. Foi bastante interessante, Francisca falou sobre o início do sindicato, sobre a relação Sepe/APPMDC, sobre marcos na história do sindicalismo e também um pouco de sua prática pedagógica. Sobre como o espaço sindical a fez crescer, e que para ela é necessário que esse envolvimento com o sindicato seja contínuo, sob pena de botar a perder tudo o que foi construído ao longo de uma trajetória. Falou também sobre a categoria, a dificuldade que as pessoas têm de votar "correto", do conservadorismo por parte de alguns e da difícil conjuntura em que se encontra o sindicalismo atualmente. (Diário de campo, 28/07/2017).

Conhecida por seu carisma e liderança, Frida foi mencionada por 10 entre 14 entrevistados, como sendo incentivadora à militância sindical. Ela foi uma das primeiras pessoas a serem cogitadas para a entrevista, no entanto, devido à conjuntura municipal, o seu ativismo, e problemas de saúde, foi quase impossível realizar o encontro que chegou a ser marcado três vezes, antes que de fato pudesse acontecer. 
Até o último minuto duvidei que conseguiria entrevistar Frida, afinal não seria a primeira tentativa de agendamento frustrado. Ao chegar à sede, ela ainda não havia chegado. Liguei para ela, temendo que tivesse esquecido nosso encontro, pois sei que tem passado dias difíceis. Pela manhã, eu já havia deixado um recado em seu celular pedindo a confirmação, mas não obtive resposta. Na ligação, Frida disse que eu esperasse um pouco, pois ela já estava a caminho. Que alívio! A entrevista verdadeiramente se realizaria! No transcurso da conversa, fomos interrompidas duas vezes, em uma delas era o secretário de fazenda ao telefone, em resposta às milhares de ligações que ela havia feito cobrando o pagamento das reposições e salário atrasado. No mais, a entrevista correu tranquila, Frida falou sem que fosse necessário que eu perguntasse quase nada, respondendo uma a uma das questões sem que eu precisasse apresentar. Falou sobre: a formação, a APPMDC, as conquistas ao longo do tempo, as fragilidades da categoria, os principais conflitos históricos e mais recentes, a história do sindicato, as memórias de lutas e relações entre o Sepe e os demais movimentos políticos e sociais da cidade. Falou, ainda, sobre ser professora, educação, suas impressões sobre a rede e o ensino. Conheci um pouco de sua história, da sua origem, mas o mais forte foi sua fala sobre o sentido de sua trajetória sindical: "Minha vida! O que me dá esperança..." (Diário de campo, 31/10/2017).

As diferentes circunstâncias de agendamento e realização de entrevista foram trazidas à tona para mostrar um pouco da complexidade do uso desse instrumento de pesquisa em função dos sujeitos e contextos em que é aplicado. A dinâmica da relação entre pesquisador e pesquisado vai além de um momento estanque de entrevista e "o trabalho intelectual não se realiza em um tempo paralisado, liberto dos desafios que são produzidos por muitas motivações. Motivações epistemológicas, sociais, políticas e históricas.” (LELIS, 1996 p.12) Não chegamos aos sujeitos por acaso - embora, no caso de Armanda e Mário, uma dose de contingência possa ter ajudado - nem tampouco os encontramos vazios de problemas, tensões e questões cotidianas.

Assim, além do estudo sobre o uso dessa metodologia, foi necessário desenvolver a capacidade de compreensão, respeito e atenção ao momento vivido por cada um dos indivíduos que se dispuseram a relatar sua história, também àqueles a quem gostaria de ter entrevistado, mas que não foi possível justamente pelas circunstâncias de sua vida e os limites da pesquisa.

Após essa elucidação sobre o contexto das entrevistas e os sujeitos entrevistados, na próxima seção faço uma análise do conteúdo abordado nos relatos sobre as trajetórias familiares, ressaltando a origem e pertencimento socioeconômico e político-cultural dos sujeitos entrevistados. 


\section{3 \\ Trajetórias familiares}

Apreendemos das histórias de vida, nos relatos sobre parentela, escolarização, profissão, ocupação dos pais, moradia e infância, algumas pistas da condição social e cultural das famílias de origem dos entrevistados. A análise desses aspectos da vida visou compreender as disposições construídas na infância que poderiam ter implicações futuras na escolha profissional e envolvimento sindical desses professores. Como expõem Souza e Berg (2010, p.128):

A família na modernidade se torna, em todas as classes, a instituição mais próxima dos corpos, a instituição que liga de forma mais intensa os indivíduos afetivamente. Portanto, cabe a ela uma dupla função, que outrora coube a outras instituições: reproduzir, em cada indivíduo - de forma durável e inconsciente - a ordem do mundo, ou seja, a dominação impessoal, que ultrapassa sempre os limites da própria família; e, ao mesmo tempo, dotar o indivíduo de racionalidade prática, de um sentido prático da classe, capaz de antecipar a ordem do mundo, ou seja, a capacidade de agir no mundo em compatibilidade com suas estruturas, antecipando essas estruturas e sobrevivendo a elas.

Desse modo, sem pretensão determinística, destaco aqui as principais estruturas familiares identificadas nas narrativas dos entrevistados, tentando, a partir delas e em diálogo com alguns autores de diferentes campos de estudos ${ }^{29}$, pensar em suas implicações individuais e coletivas.

\subsection{1 \\ Origem, território e pertencimento social}

Nessa seção, destaco e analiso alguns aspectos relacionados às origens dos professores militantes, no que diz respeito à sua naturalidade, condições de moradia na infância, pertencimento social e deslocamentos que marcaram sua trajetória.

O município de Duque de Caxias é o cenário da história de vida da maior parte dos entrevistados. Cora, Galeano, Rosa, Nise, Mário, Elis, Clarice, Cecília e Francisca são naturais desse município ou do entorno, Baixada Fluminense e periferia do Rio de Janeiro:

\footnotetext{
${ }^{29}$ Autores de diferentes campos contribuem para a compreensão das questões sobre família. Para maior aprofundamento, indico: Ariès (2012), Singly (2007), Nogueira (1998), Souza (2010) e Barros (2006).
} 
Eu sou nascida em Caxias mesmo, de uma família, inicialmente, de quatro filhos. A caçula de um primeiro casamento do meu pai; sou a caçula de quatro filhos. Após o falecimento da minha mãe, o meu pai se casou novamente e teve mais três filhos, sendo que um faleceu ainda bebê. Somos de família muito humilde, origem muito humilde. (Clarice).

Eu nasci no Rio de Janeiro. Vim pra Caxias, com 9 meses de idade e só fui sair daqui já com 50 e poucos anos, quando eu morei dois ou três anos, eu morei três anos em Santa Teresa. Depois retornei a Caxias, casei em Caxias, com um rapaz de Caxias. Tive meus filhos aqui, inclusive e os criei, basicamente, aqui em Caxias. Daí a minha relação tão grande. (Francisca).

Assim, para esses professores, além de ser o local de trabalho, Duque de Caxias é onde viveram e construíram sua história, desde a sua família de origem.

Para quatro entrevistadas, o processo migratório também apareceu como uma referência forte em suas vidas: os avós de Nise são imigrantes italianos; a família de Dandara migrou do interior do Ceará para o Rio de Janeiro; os pais de Tarsila se conheceram em São Paulo e, só mais tarde, vieram para o Rio de Janeiro; os pais de Elis se mudaram do interior do Espírito Santo para Duque de Caxias. Elas relataram as memórias do processo vivido em suas famílias que, de modo geral, deslocaram-se para o Rio de Janeiro em busca de melhores oportunidades de vida.

Porém, assim como em outras grandes regiões metropolitanas, as oportunidades encontradas eram restritas, sobretudo no que diz respeito à moradia, fazendo com que essas famílias buscassem cidades como Duque de Caxias, localizadas na periferia de grandes metrópoles.

Braz \& Almeida $(2010)^{30}$ ressaltam essa característica da história do município caxiense, assim como o papel dos migrantes em sua formação:

Ao longo desse período formador, seus novos habitantes, migrantes recéminstalados, enfrentam duras condições. Essa corrente migratória ocupou desordenadamente e desigualmente as terras desse distrito de Nova Iguaçu, nos anos 1930 e no jovem município emancipado [Duque de Caxias] a partir dos anos 1940 e 1950, e deparou-se com o desafio de superar as carências e ausências relativas às condições mínimas necessárias para um assentamento digno com infraestrutura urbana básica e serviços públicos adequados. (p. 111).

Nas falas de Nise e Elis sobre o período da infância, essas condições de precariedade no âmbito da habitação e saneamento aparecem como pano de fundo:

A gente também tem a lembrança da infância brincando na rua, correndo na rua... À noite, os pais ficavam sentados na rua conversando. Aqui custou muito a chegar a

\footnotetext{
${ }^{30}$ Esses autores fazem parte de um conjunto de pesquisadores que atuam em um esforço conjunto e contínuo de resgate e valorização da história do município de Duque de Caxias e da Baixada Fluminense.
} 
energia elétrica, por isso tanto sapo, porque era com lamparina, olha que coisa! Aqui era brejo, você vê pela praça, ali onde é a praça hoje era só brejo! (Elis).

Nossa... Da escola a gente ia para casa, brincava muito, brincadeiras de rua, participei de todas! Pique bandeira, queimado e era uma infância muito sadia, ruas sem asfaltar, vala aberta... Valas abertas, mas a gente era muito feliz, mesmo com toda essa dificuldade. (Nise).

Assim, o processo migratório que constituiu a história do município de Duque de Caxias também marcou a vida de seus moradores, que com a ausência de serviços básicos foram driblando as dificuldades e construindo sua história.

Esses deslocamentos se sobressaem também nas histórias de Mário, Dandara e Rosa que por razões de casamento, divórcio, acomodação da família em função das restrições orçamentárias passaram por mudanças de cidades, bairros e casas ao longo da vida:

Foi na década de 80 que a gente veio pra Caxias. Depois de morar em muitos lugares. Porque quando a gente morava na Penha, a gente morava de aluguel, aí sabe como é aluguel, aumenta esse ano, o outro ano você muda. Aumenta esse ano, o outro ano você muda. Antes de vir morar em Caxias, a gente morou bastante tempo na Vila Cruzeiro, que foi onde a gente morou mais tempo, depois morou em Bonsucesso, depois morou em São João. Morou em Éden, ficou nesse círculo Baixada e Rio... Na década de 80 também meu avô faleceu e a nossa casa que era a casa dele estava muito abandonada... Aí a gente mudou para a casa do meu avô, acho que esse foi o fator determinante porque aí você sai do aluguel e vem para a casa própria. [...] A gente vem para cá e se estabelece direto em Caxias, aí está aqui desde sempre, não consegue tirar esse vínculo. Porque quando eu comprei a minha casa, engraçado que eu estava procurando a minha casa no Rio. [...] Eu que dizia que ia comprar uma casa no centro do Rio, acabei comprando aqui também. (Rosa).

$\mathrm{Na}$ fala de Rosa, chama a atenção a constante movimentação entre bairros pelos quais sua família passou, impulsionada pela falta da casa própria, a busca por uma nova moradia à medida que o preço do aluguel aumentava, até o momento do retorno à casa do avô, em Duque de Caxias. Entre idas e vindas, ela relata que essa cidade sempre esteve presente em sua vida, como local de guarda para seu irmão menor, o qual a mãe temia ser "influenciado pela comunidade".

Como a gente sempre morou perto da comunidade, na comunidade mesmo, a minha mãe tinha muito medo, então ficava assim, a minha mãe ficava com a gente, mas o meu irmão praticamente, ele ficava mais na casa do meu avô porque era uma maneira dele não ficar todo o tempo lá. (Rosa).

Os deslocamentos feitos pela família de Rosa são diferentes dos realizados pela família de Dandara, cujas mudanças na infância apontam para uma ascensão social, ainda que dentro dos estratos mais baixos de uma "classe intermediária". O 
que pode ser atribuído ao fato de sua mãe ser empregada pública federal, dando à família certa estabilidade e condições de melhoria:

[...] é uma família de classe intermediária, não vou falar que era pobre, tipo assim, não passava necessidade não, porque na época minha mãe trabalhava no hospital federal e minha mãe ganhava relativamente bem para as pessoas que moravam no nosso bairro, eu morava em Irajá. (Dandara).

$\mathrm{Na}$ história de vida de Cora, a questão da moradia revela um pouco da oscilação financeira pela qual passou sua família, entre altos e baixos enfrentados após a morte do pai, o retorno ao antigo casebre da família foi a solução encontrada:

Meu pai já tinha um terreno no bairro Doutor Lauriano ${ }^{31}$ e tinha lá uma casinha, onde a minha avó, a mãe da minha mãe morava, cedida pelo meu pai. Então, com a morte dele, nós tivemos que juntar todos, porque calhou de pedirem a casa... Aí, ficou minha avó, meu tio, eu, minha irmã e minha mãe e ficamos todos na mesma casa e cada um começou a se virar. Minha mãe demorou um tempo para começar a receber a pensão, mas começou, e aí as coisas foram caminhando. A gente juntou o $13^{\circ} \mathrm{da}$ família inteira para colocar luz, porque a gente não tinha luz própria, a luz era cedida de um vizinho. Então, assim, foram muitas dificuldades, mas a gente sempre com muita garra. (Cora).

Ao analisarem as etnografias realizadas em bairros de trabalhadores no Grande Rio, Guedes \& Lima (2006, p. 133) ressaltam que a casa para esse grupo é um "espaço fundamental, locus da instituição da família, através da qual se constituem como pessoas e, por esta via, como partícipes de uma sociedade mais ampla." Para as autoras:

A relação entre casa e família apresenta-se nas pesquisas que realizamos, orientada pelo modelo da família nuclear conjugal, sendo em princípio, considerada o espaço social próprio e inerente a essa instituição social. Nesse caso, o pertencimento é delimitado pelas relações conjugais e de filiação, que delimitam, ao mesmo tempo, uma unidade com fronteiras claras. Trata-se, como bem demonstra Lévi-Strauss (1986), de uma das formas de organização social mais difundidas no mundo, sendo encontrada em diferentes sociedades e épocas. (p. 134).

Nos relatos dos nossos entrevistados, a importância da casa para a família converge com a relevância desse bem, apresentada por Guedes \& Lima (2006), no entanto, quanto ao modelo familiar, embora haja a predominância do formato nuclear, percebemos outros arranjos e reconfigurações, como por exemplo, nas falas de Rosa, Cora, Mário, nas quais o divórcio, morte ou re-coabitação entre as gerações (Peixoto \& Luz, 2007) alteram a estrutura nuclear.

\footnotetext{
${ }^{31}$ Bairro do $1^{\circ}$ Distrito de Duque de Caxias, centro da cidade.
} 
Outra questão a se pensar é a relação entre o processo de ocupação territorial e as desigualdades sociais que impulsionam a população a se estabelecer em determinados lugares, de acordo com sua condição social e as oportunidades de trabalho e renda.

Até recentemente, cidades como Duque de Caxias eram apelidadas de “cidades-dormitório", pois a população se deslocava até a capital do Estado para trabalhar, enfrentando longos percursos e o trânsito das principais vias de acesso aos centros urbanos.

Em uma análise dos deslocamentos feitos pelas populações dentro de metrópoles como o Rio de Janeiro e suas circunvizinhanças, Lago (2007) volta à gênese do conceito de "cidade dormitório" para questionar a permanência de seu uso diante das mudanças de configuração na vida na cidade: A noção de periferia, construída nos anos 1970 nos marcos da sociologia urbana
marxista e incorporada em seguida ao senso comum, qualifica um determinado
território na metrópole pelo conjunto de carências que só nele são encontradas:
carência de serviços públicos básicos, de urbanização das áreas públicas, de
titularidade da propriedade e de proximidade do mercado de trabalho, entre outras.
A noção de "cidade-dormitório" surgiu como síntese dessas carências e das enormes
distâncias a serem percorridas diariamente entre o lugar da moradia e o do trabalho.
Portanto, a "periferia" como lugar do trabalho romperia com a definição em uso.
(Lago, 2007, p. 9).

Para a autora, nos últimos anos "houve uma redução da mobilidade casatrabalho de longa distância para os moradores da periferia, o que permite pressupor que o mercado de trabalho não só se expandiu nessas áreas, mas absorveu parte da mão de obra local." (p. 10).

Nos relatos analisados, a questão dos deslocamentos é superada com o ingresso desses professores na rede pública de ensino de Duque de Caxias. Dessa forma, esse grupo conquista tanto a estabilidade financeira a qual seus pais não tiveram acesso, quanto o rompimento com a necessidade de grandes deslocamentos para o trabalho. Esses dois fatores permitem aos indivíduos a permanência na cidade e o fortalecimento de vínculos com esta.

Portanto, a seguir, prossigo apresentando esse processo de transição e ascensão desse grupo de professores, destacando valores e vivências relativas ao trabalho e à escolarização. 


\subsection{2}

\section{Trabalho e escolarização}

De modo geral, o grupo de entrevistados tem origem em famílias com baixa escolarização, que exerciam profissões cujo grau de escolaridade exigido é o "antigo primário", ensino fundamental, ensino médio ou até mesmo, ocupações sem vínculo profissional algum, tal como as donas de casa e bordadeiras.

São famílias pertencentes à classe trabalhadora, algumas de origem muito humilde: "Minha família sempre foi uma família pobre e trabalhadora, meus pais eram separados desde muito novo e minha mãe sempre foi uma mulher extremamente batalhadora." (Mário).

Nise é descendente de imigrantes vindos da Itália, seus pais eram trabalhadores rurais que migraram do Estado do Espírito Santo para o Rio de Janeiro em busca de melhores condições de vida: "Meu pai trabalhava na roça, veio tentar a vida aqui no Rio de Janeiro, junto com os irmãos dele e minha mãe veio trabalhar em casa de família.” Analisando a história de sua família, Nise descobre que seus "bisavôs vieram num navio de imigrantes, naqueles navios cargueiros". Ela relata essa história com bastante orgulho, dizendo que ao tomar ciência de suas raízes, compreendeu sua ligação com os movimentos populares e trabalhistas, sempre a favor dos oprimidos:

Descobri que meus bisavôs vieram num navio de imigrantes, naqueles navios cargueiros que traziam imigrantes, trabalhando no navio e aí, enfim, começaram a história aqui no Brasil. Isso foi muito legal porque a gente busca a identidade da gente... Porque embora eu seja branca, minha cor seja branca, mas a minha origem é da classe trabalhadora: são pessoas humildes que lutaram pela sobrevivência, que podiam ser vítimas mesmo daquela circunstância toda, então, é um grupo que chegou também fugindo da exploração e tentando a vida. E meus pais criaram os quatro filhos com muita humildade, a gente começou a trabalhar muito cedo. (Nise).

Rosa, de fala muito forte e incisiva, iniciou o relato de sua vida assim: "Filha de mãe costureira, pai sapateiro, mãe arrimo de família...”, ressaltando o peso da ocupação de seus pais na sua trajetória de vida, com bastante adversidade no campo econômico.

Assim como nas histórias de Mário, Nise e Rosa, nos demais relatos a ocupação e escolarização dos pais indicam o pertencimento social dessas famílias às camadas populares: 
Minha mãe costurava pra ajudar nas finanças de casa, meu pai era eletricista, então era autônomo, se tinha coisa pra consertar, tinha dinheiro, se não tinha, não tinha e aí depois, quando eu já tinha uns 12 anos, ele conseguiu entrar pra gari da Comlurb, aí foi que a vida estabilizou um pouco porque ele passou a ter emprego de carteira assinada... Tinha salário direitinho porque antes não tinha isso, então assim, eu fui criada nessa família. Meu pai só fez até a admissão porque ele só estudou até a $4^{\mathrm{a}}$ série, depois não tinha possibilidade de estudo... (Cecília).

Entre a instabilidade, tentativas de melhoria, revezes no campo profissional e na vida de modo geral, as mudanças de ocupação, abertura de negócio próprio e ingresso precoce dos filhos no mercado de trabalho fizeram parte das estratégias de sobrevivência das famílias:

E aí, somos três irmãos, minha mãe sempre aquela coisa de dona de casa e fazendo alguns bicos para ajudar. Meu pai, inicialmente, tinha uma vida um pouco mais estável, que ele era do BANERJ, um banco importante, mas naquela época, nos anos 90 veio a crise, época do Collor, aí já deu uma desorganizada e a gente, desde novo, começou a trabalhar porque ele sozinho já não dava conta. (Tarsila).

Ele [o pai] tinha uma fabriqueta de bebidas, dessas bebidas, que se vende em vendinhas. E desde os 9 anos de idade que eu trabalhava, todos os três filhos, na época éramos três. (Francisca).

De acordo com as características levantadas, para além da renda e da ocupação, mas pelo modo de vida e maneira de se estruturar dessas famílias, seria possível entender que eles se aproximam do que Souza (2010) chama de "os batalhadores" ao analisar empiricamente a vida de sujeitos que ascenderam socialmente através do "capital familiar" e de uma "ética de trabalho duro".

[...] essa classe conseguiu seu lugar ao sol à custa de extraordinário esforço: à sua capacidade de resistir ao cansaço de vários empregos e turnos de trabalho, à dupla jornada na escola e no trabalho, a extraordinária capacidade de poupança e de resistência ao consumo imediato e tão ao mais importante do que tudo o que foi dito, a uma extraordinária crença em si mesmo e no próprio trabalho. (p. 50).

Souza \& Berg (2010, p. 50) chamam esse conjunto de disposições interligadas de "capital familiar", fundamental na "transmissão de exemplos e valores do trabalho duro e continuado, mesmo em condições sociais muito adversas". E o núcleo desse capital, se consubstanciaria na transmissão de uma "ética do trabalho", diferente das camadas médias, onde, segundo o autor, “a 'ética do trabalho' é aprendida a partir da 'ética do estudo'."

Para Souza \& Berg (2010, p. 51), diferente de uma classe média privilegiada "a necessidade do trabalho se impõe desde cedo, paralelamente ao estudo, o qual 
deixa de ser percebido como atividade principal e única responsabilidade dos mais jovens".

Os relatos de Cora e Elis exemplificam essa entrada precoce no mercado de trabalho em detrimento da dedicação aos estudos, dadas as condições econômicas da família:

E a minha irmã parou de estudar aos 12 anos, ela foi para casa de família aos 12 anos com uma promessa de que iria continuar estudando e foi enganada, uma história muito sofrida. Então, a minha mãe não queria o mesmo para mim, então eu tive que arrumar trabalho rápido, mas ela dizia assim: "Tem que continuar estudando..." e aí aos 13 anos, eu fui trabalhar em casa de família por aqui. Trabalhava aqui e estudava. Depois apareceu um dono de uma escola particular e a minha mãe: “Ah, não tem um empreguinho para minha filha?" E aí ele me contratou para trabalhar na casa dele com a promessa de que eu continuaria estudando. Aí continuei, realmente eu consegui. Fui para casa dele aos 14 anos e fiquei lá até o $1^{\circ}$ ano do ensino médio. Então terminei o ensino médio. (Elis).

Desconfiada, após a promessa frustrada de continuidade de estudos à filha mais velha, a mãe de Elis, sem poder garantir a dedicação exclusiva da filha mais nova aos estudos, pede a um dono de escola que empregue sua filha e lhe garanta uma bolsa de estudos. Essa foi uma estratégia encontrada pela família que valorizava a escolarização, mas não podia abrir mão da ajuda financeira que o trabalho dos filhos proporcionava.

No caso de Cora, a luta pela concretização do sonho da escolarização foi ainda mais complexa, com uma trajetória escolar cheia de interrupções, Cora demonstra em seu relato a perseverança a despeito das adversidades impostas pela condição social:

Eu comecei a trabalhar muito cedo, eu ainda não tinha completado 16 anos. [...] Naquela época, a gente não tinha muito acesso à informação e escola pública era muito difícil, então, eu não tive acesso... Era difícil de conseguir vaga. Eu estudei em escola privada. Meu pai que custeava. Só que com a morte dele, ficou muito difícil para a minha mãe. [...] Eu e a minha irmã passamos por muitas dificuldades. E eu querendo estudar porque sempre gostei muito de estudar, mas a situação impedia. [...] A minha sorte foi eu encontrar essa pessoa que queria doar bolsas de estudo. Ele era dono de uma escola... Encontro com ele e sempre que o encontro eu lembro essa história e agradeço muito a oportunidade que ele me deu naquela época de voltar a estudar fazendo supletivo à noite porque eu trabalhava na fábrica de dia e voltei a estudar o antigo primeiro grau, que era o ensino fundamental que eu não tinha concluído. E consegui em um ano terminar o meu primeiro grau. Sem pagar nada. Eu agradeço imensamente essa oportunidade. Nem a carteirinha escolar eu paguei [...]. Eu só tinha mesmo a dificuldade de passagem porque eu tinha que sair da fábrica e ir para a escola. Muitas vezes, só com o dinheiro da passagem, sem poder tomar um lanche, nada. Então, eu saí da fábrica aos 18 e já pegava ônibus direto para a escola e lá ficava até... Eu lembro que o último horário era dez e quarenta. Sem poder tomar um cafezinho porque a minha renda era para complementar o sustento 
da casa junto com a minha mãe e a minha irmã menor que também trabalhava em uma fábrica. E ali, naquela dificuldade toda, eu consegui concluir. (Cora).

Embora extenso, optei por trazer esse relato pela força com que expressa os sentimentos de dificuldade, sonho, gratidão, limitação, os quais são melhor transmitidos pelas palavras de quem viveu e sentiu a impossibilidade da escolarização pelas circunstâncias que se apresentavam, tornar-se realidade, através do recebimento de uma bolsa. O relato traz a concretização de um desejo, não sem restrições, inclusive alimentares.

O valor da escola e do estudo está presente também nos relatos de incentivo e acompanhamento dos pais na vida escolar dos filhos, ainda que esses tivessem pouca ou nenhuma escolarização:

[...] essa mulher analfabeta [a avó] que botava a gente para estudar... Fazer os deveres de casa e ela corrigia, aí a gente ria porque ela não sabia ler, aí ela ia para ver se estava certinho, sabe? Tipo como as professoras fazem: "A letrinha está bonitinha e tal", ela via por ali, mas sentava sempre a gente para estudar, sempre deu gibis para a gente e ela não sabia ler. (Dandara).

Eu vi que eles [os pais] não tiveram a oportunidade, mas todas as oportunidades que eles não puderam ter, eles tentaram dar para a gente, para os filhos... E sem saber, mas, a oportunidade de estudo é uma coisa que meus pais sempre fizeram questão de dar. (Nise).

Por parte da família, o desejo de que os filhos progredissem na vida escolar conflitava com as condições objetivas de vida e conduziam ao ingresso precoce no mercado de trabalho.

Porém, parte da dificuldade no processo de escolarização relatada pelos entrevistados pode ser explicada também pela dificuldade de acesso à educação básica - ausência de vagas em escolas públicas próximas à residência - que só foi amenizada após LDB 9.394/96. Para Gatti e Barreto (2009, p. 11):

A escolarização no Brasil foi durante séculos apanágio das elites, em que pese a existência de propostas educacionais em documentos e estudos, em debates entre teóricos, filósofos, políticos e religiosos, e em algumas poucas escolas, porém sem um correspondente em política inclusiva da população como um todo na escola. Até esse período, era muito pequena a oferta de escolas públicas diante do crescimento populacional brasileiro. Tanto que a grande discussão dos educadores críticos dos anos 1960 e 1970 foi a questão da enorme massa populacional analfabeta ou semianalfabeta no Brasil, com poucas condições de efetiva participação na vida cidadã e no mundo do trabalho que se sofisticava. Estudantes de ensino médio e superior representavam uma quantidade mínima na população brasileira. 
Assim, frente à escassez de vagas no sistema público as famílias de Cora, Elis, Rosa e Cecília encontraram nas bolsas de estudos em escolas privadas o caminho para a escolarização.

Mãe costureira, divorciada, cuidando de três filhos, arrimo de família e assim, nessa formação a gente passou num processo de bolsa em escola católica porque a gente chegou no início a estudar na Nossa Senhora de Penha, que é uma escola católica no Rio, porque a gente morava no Rio, morava na Vila Cruzeiro... E aí oferecia bolsa para a comunidade. (Rosa).

Especificamente na história de Cecília, aparece também a figura de uma professora alfabetizadora, que ensinava as crianças do bairro em casa, em uma espécie de "escolinha informal":

Quando a gente saiu dessa casa porque antigamente era assim, você era alfabetizada e depois ingressava na escola regular, você não era alfabetizado na escola regular, essa mulher que era uma vizinha que tinha uma escolinha na casa dela, ela alfabetizava as crianças dali da redondeza e quando a gente aprendia a ler, era o ingresso na escola regular, então depois que eu fui para a escola que também era particular na época, que não tinha pública não, só que eu era bolsista porque teve uma época que o governo para investir, porque não tinha escola pública, começou a dar bolsa. (Cecília).

O baixo nível de escolaridade dos pais e a não obrigatoriedade do oferecimento dos anos "pré-escolares" da educação básica pelo poder público favorecia a oferta desse tipo de serviço.

Embora seja um fator limitador das relações com a escola, a baixa escolaridade dos pais não significou a omissão da família em relação à vida escolar dos filhos (Thin, 2006; Lahire, 2004). No caso de Dandara, por exemplo, o acompanhamento das lições de casa ${ }^{32}$ era realizado pela avó que não sabia ler, mas que desempenhava um papel importante na valorização dos estudos. Outra figura importante na trajetória escolar dela foi sua irmã mais velha, a primeira da família a ir à universidade. Já sua mãe, embora letrada, enfermeira concursada, não tinha tempo de ajudar na educação da filha.

Lahire (2004, p. 338) afirma que "a presença objetiva de um capital cultural familiar só tem sentido se esse capital cultural for colocado em condições que tornem possível sua 'transmissão'.”

De acordo com Nise, sua família, embora apenas com o "antigo primário", fez da ausência de oportunidades escolares a principal motivação para a

\footnotetext{
${ }^{32}$ Para maior aprofundamento sobre o acompanhamento escolar pelas famílias de setores populares, indico a leitura das obras de Portes (2000) e Resende (2013).
} 
"valorização dos estudos" dos filhos, o que, segundo ela, a faz lutar até hoje por melhores condições de ensino e aprendizagem para as camadas populares.

Ao considerar a família como um importante elemento na determinação dos destinos pessoais e sociais, Setton (2002, p. 112) alerta que:

Nas trajetórias educacionais e profissionais dos sujeitos é preciso atentar para a heterogeneidade de configurações familiares, a diversidade de recursos e posicionamentos sociais, bem como a diversidade de comportamentos e relações que podem estabelecer com as outras instâncias socializadoras.

Assim, certa da importância da família para a constituição das identidades individuais e sociais continuarei abordando, a seguir, as questões referentes à educação dos entrevistados, a transmissão de valores morais através da interface com outras instituições e instâncias sociais, como a igreja, a política e as relações de gênero dentro da dinâmica familiar em que cresceram.

\subsection{3 Valores familiares: gênero, religião e política}

Autores como Phillippe Ariès (2012) e François de Singly (2007) estudam sobre as transformações que a instituição familiar sofreu ao longo do tempo, ressaltando a importância do estudo histórico e sociológico acerca da família para compreensão dos sujeitos e da própria sociedade em que vivem.

Nos relatos dos entrevistados, ficaram registradas as marcas de classe, gênero, religião e valores, forjados na educação familiar e contexto social de nascimento. Cada uma dessas questões se entrelaça, constituindo no interior das famílias o primeiro processo de socialização dos indivíduos.

A ligação dos pais a uma religião, o modo de viver a fé e as regras da instituição religiosa são questões importantes na inculcação de valores e modos de viver a infância, citados por Galeano, Nise e Cecília:

Minha mãe era uma pessoa muito questionadora das coisas, ela nunca aceitava as regras sem refletir sobre elas. Então, a gente é de uma família evangélica, minha mãe era evangélica. A igreja em que ela foi criada era uma igreja muito mais... É... Cerceadora do que hoje em dia. Então, assim, na época dela isso já era muito pesado, então não podia ir ao cinema, não podia assistir futebol, não podia ir a nada. [...] Mas, mesmo assim, ela sempre foi muito questionadora, à frente das ideias. Ela sempre olhou a bíblia na perspectiva da relação direta com Deus e não através de terceiros, que é a igreja. Então a igreja tem as regras, ela sempre ensinou a gente a obedecer as regras, mas sempre questionando e ponderando que aquela regra ali para 
Deus não tinha sentido, ela era uma regra humana, ela era uma regra da instituição, não era uma regra da relação com Deus, isso eu aprendi com ela. O meu pai não, o meu pai era castrador, era radical, meu pai, se a gente chegava em casa, tivesse feito uma aparadinha no cabelo, ele fazia um escândalo, ele dizia que à noite, quando a gente dormisse, ele ia deixar a gente careca para a gente não cortar cabelo. Então era meio que um terror, uma pressão, ele sempre foi assim, muito terrorista, muito radical. (Cecília).

Para Cecília, a vivência da religião do período da infância à adolescência significou a imposição de restrições de ordem social e cultural. Pode-se dizer que as restrições impostas pelo pai se estendiam também para o campo simbólico, implicando em limitações na construção da autoestima e autonomia para como o próprio corpo. Embora tenha sido sempre instruída à obediência, Cecília encara com positividade a postura questionadora da mãe frente à religião, separando o que é parte da "relação com Deus" do que é "regra criada pelo homem".

Nas histórias de Olga e Zilda está presente a pluralidade religiosa dentro da família:

A minha mãe veio de uma família ligada à Igreja Evangélica Assembleia de Deus, meu pai era espírita e eu tive uma militância na Igreja Católica. Quer dizer, era uma miscelânea. Mas tenho muitas referências, por causa da minha família, por parte da minha mãe, na igreja evangélica. (Olga).

O meu pai sempre foi muito católico. Minha mãe, não tinha religião... Nunca teve religião nenhuma, e a minha avó materna era batista e minha mãe tinha uma certa posição contrária a estimular filho a ter religião porque a minha vó obrigava a ir para Igreja Batista, e minha mãe os filhos dela iam decidir o quê que eles iriam ser. (Zilda).

No caso de Francisca, uma adesão forçada ao catolicismo foi a estratégia encontrada por sua mãe, espírita, para proteger a filha do preconceito:

A minha mãe era espírita kardecista, meus avós eram kardecistas, minha avó era rezadeira, meu avô era médium, mas, a minha mãe, embora uma mulher, que tivesse estudado até a $4^{\mathrm{a}}$ série, ela era bastante inteligente, ela percebia, que a maior parte da sociedade era católica. E, que quando você falava que era espírita, as pessoas já tinham... Então, ela fez o quê? Crismou a gente, batizou, tenho fotografias com aquela roupinha de batizado, com a velinha na mão, mas com 15 anos aqui na Igreja Matriz de Santo Antônio, logo após ela ter sido inaugurada, eu mesma me vi dentro da igreja me perguntando assim, sem aceitar muito aquilo, sabe? E aí, dali eu fiz um rompimento e vim recuperar isso, depois dos 50 e poucos anos, que aí eu me voltei para o espiritismo, embora não seja também uma praticante... (Francisca).

Na trajetória de Galeano, a religiosidade propiciou, em certo ponto, a reflexão sobre determinadas opressões sociais. Segundo ele, a igreja está entre as instituições que o ajudaram no processo de construção de um "olhar crítico" sobre a sociedade: 
[...] eu também tenho na igreja, das comunidades de base, e a gente é adepto à teologia da libertação, então ajudou a gente a ter um olhar crítico, até nesse aspecto religioso para o mundo que nos cerca. Olhar o mundo e ver quem são os oprimidos, os faraós do nosso tempo e isso, de certa forma, influenciou bastante a forma como eu pensava a teologia... (Galeano).

Silva (2012) ressalta a força da teologia da libertação e das Comunidades Eclesiais de Base (CEB) junto à população através de "um trabalho de organização e conscientização política”. Para a autora, a Igreja Católica, e especialmente os bispos Dom Adriano Hipólito e Dom Mauro Morelli ${ }^{33}$ tiveram um papel fundamental no movimento popular ocorrido entre os anos 1960 e 1990 na Baixada Fluminense.

Nise ressalta que cresceu em "uma família tradicional, católica" do tipo nuclear, ou restrita, como propõe Singly (2007) - "Eu cresci dentro de uma família tradicional, nos moldes da família... Pai, mãe e irmãos.” Recebeu uma educação muito rígida que marcou sua infância pela proibição de determinadas diversões e acesso a outros universos sociais que não fossem a igreja:

[...] a gente é católico e aqui em Caxias tem uma forte influência das Comunidades Eclesiais de Base. Então, eu adorava... A gente ia para o grupo jovem porque meu pai, como ele era tradicional, ele não deixava a gente sair com amigos, não deixava nem dançar festa junina por contato com outros meninos, então era rigoroso mesmo. Aí, a igreja podia [risos]. Então, a gente acabou indo para o grupo jovem, eu e minha irmã mais velha, porque a gente sofreu mais, sofreu [sem] essa liberdade. Depois, a minha irmã mais nova e meu irmão, que são mais novos, eles já podiam ir depois em discoteca, coisa que a gente não pode. Uma diferença de 5 anos, mas tem uma grande diferença naquele momento, teve uma grande diferença. Então, eu e minha irmã fomos educadas mais no conservadorismo. (Nise).

No riso irônico de Nise, ela sinaliza o que para ela, à época, era uma espécie de caminho para a "liberdade" (ainda que vigiada) e hoje lhe parece uma contradição: "na igreja podia". A concessão dada pelo pai para que frequentasse o ambiente religioso significou para sua adolescência o único contato com os jovens para além dos limites da família.

Além da distinção na criação de irmãos de gerações diferentes, como maior complacência aos mais jovens, também ficaram registradas nas memórias de Nise a diferenciação entre a educação dos meninos e das meninas: "Tratou a gente com muito rigor, principalmente as meninas."

\footnotetext{
${ }^{33}$ Esses bispos foram responsáveis pelas dioceses de Nova Iguaçu (1996 a 1994) e de Duque de Caxias (1981 a 2005), respectivamente.
} 
Discutindo estereótipos sexuais e relações de gênero em discursos de mães, Reis \& Maia (2009, p. 141) apontam para a diferenciação na criação de meninos e meninas:

Na educação familiar, portanto, imperam diferentes atitudes parentais em função de crenças sociais atribuídas aos filhos e filhas quanto ao gênero. Estudos realizados a respeito da educação de filhos relatam as diferenças em criar meninos e meninas, destacando inclusive diferentes formas de tratamento e conduta com ambos os sexos, de acordo com a concepção do que é ser feminino e do que é ser masculino.

Assim como Nise, Elis ressalta as diferenças de educação por gênero e geração em sua família: "os dois mais velhos tinham que ser servidos pelas duas [irmãs mais novas]". Assinalando a divisão de tarefas que se estabeleceu em sua família, ela relata:

[...] as mulheres tinham que fazer tudo para os homens. A minha mãe trabalhava e uma época a minha irmã foi trabalhar na casa de família aos 12 anos e eu fiquei responsável a dar comida para os homens da casa e lavar a roupa, então eu tinha que cuidar do uniforme dos menores, são dois mais novos que eu. E o irmão mais velho trabalhava e chegava muito cedo em casa... E a minha mãe me dava ordem: "Não atrasa a janta!" Cinco horas, eu tinha que estar com a janta pronta... A minha infância foi isso, mas não sofro, acho que assim passou... Ah, e tinha que lavar as camisas do meu pai, porque eram poucas, todo dia tinha que ter camisa limpa, então a minha obrigação era lavar a camisa do meu pai, do meu irmão, uniforme do meu irmão e fazia comida. [...] Aí tinha o pequenininho... Quando a minha mãe foi trabalhar, eu chegava da escola, tirava ele do berço, dava comida, tirava cocô - essa coisa do cocô também era horrível! - muito trabalho, muito trabalho. (Elis).

Para Reis \& Maia (2009, p. 141), a atribuição de atividades domésticas às meninas faz parte de um conjunto de situações que compõem uma socialização sexista:

Na socialização sexista, as meninas são mais estimuladas a brincar em espaços restritos e, ao mesmo tempo, a praticar tarefas femininas, como atividades domésticas (limpar, arrumar, ordenar) e a maternidade (cuidar). Ao mesmo tempo, são também convencidas a desejar desempenhar profissões, na vida adulta, retraídas e pouco ousadas, como, por exemplo, ser costureira, empregada doméstica, babá ou secretária. Já aos meninos os incentivos são para brincadeiras em espaços mais amplos, o que provavelmente possibilita desenvolver mais a orientação espacial. Também são mais estimulados em relação à autoconfiança e à autoestima, pois lhes é permitido expressar mais livremente comportamentos tidos como "inadequados". Meninas são cobradas para ficar "limpinhas", "arrumadinhas" e "enfeitadinhas", e meninos são menos cobrados, caso apareçam "sujos", "desarrumados" em função de suas brincadeiras agressivas e movimentadas. Ao mesmo tempo, são também convencidos a desempenhar profissões, na vida adulta, expansivas e ousadas, como, por exemplo, ser astronauta, bombeiro, engenheiro, advogado ou presidente.

No relato de Elis, especialmente, as questões de gênero apontadas por Reis \& Maia (2009) se somam às de classe, ao ter presente em seu cotidiano familiar a 
emergência da necessidade de trabalho, sendo ela ainda criança a responsável por dar suporte aos demais membros de sua família, desempenhando praticamente sozinha todo o trabalho doméstico.

Sobre a educação recebida na infância, Dandara fala a respeito da presença marcante de sua vó que cuidava dos netos enquanto sua mãe, afastada de casa pelo trabalho, cumpria plantões no hospital: "As cinco filhas ficavam com a minha avó, então eu fui criada pela minha avó e, como eu sou a caçula, já viu... E a minha mãe trabalhava muito, fazia plantões, ficava mais tempo dentro do Hospital do Andaraí do que em casa..."

Nas memórias dela, as punições pelas traquinagens eram distribuídas "com igualdade” entre as netas: “A minha irmã era levadíssima! Se ela fazia alguma coisa, ela [a avó] batia na minha irmã e batia em mim, aí era assim: uma fazia, pagavam todas..." (Dandara).

No silêncio sobre a presença do pai em sua criação, inferimos que tenha sido pouco significativa, ou nula, muito provavelmente por sua morte prematura e por conta do pensamento que imputa à mulher a responsabilidade do cuidado com as crianças. Na ausência da mãe, esse papel é atribuído imediatamente a outra mulher:

[...] a criação, como era a minha avó, foi uma criação é... Eu diria um pouquinho feminista porque a minha avó... Eu sempre escutei a minha avó falando assim: "Se eu pudesse, eu não tinha casado", porque ela casou cedo. [...] E a minha avó morreu com 102 anos. Há 9 anos atrás, 102 anos e ela sempre gostou de estar no mundo atual. Ela era aquela mulher bem à frente do tempo dela, só que ela era analfabeta... Analfabeta, mas tinha uma inteligência! E tinha umas tiradas, sabe? Sensacionais! Então, nós fomos criadas com essa mulher analfabeta que botava a gente para estudar... (Dandara).

Ao falar sobre sua avó, Dandara não esconde o orgulho e a saudade, sendo necessária uma pausa na entrevista para que ela se recompusesse emocionalmente. A visão de Dandara sobre uma possível inclinação de sua vó às ideias feministas tem relação com sua militância hoje, no movimento de mulheres negras. Dentro do sindicato ela faz parte da secretaria "Gênero e combate à homofobia" e sempre levanta questões sobre o papel da mulher no movimento sindical.

Armanda conta que sua família, após a morte de sua mãe, ficou composta por quatro homens e apenas ela de mulher. Apesar disso, a educação recebida foi voltada para a igualdade entre os gêneros:

[...] ela [a mãe] faleceu quando eu tinha 5 anos, então eu não convivi e aí eu fui criada pelo meu pai e pela a família da minha mãe [...]. Eu fui criada numa família que a 
gente não pode dizer que é tradicional, porque era um homem com 4 crianças na mão, ele fazia tudo com a gente, então era de fato, na década de 80 , algo assim de se espantar... A minha ficha só caiu depois que eu fui mãe... Porque eu lembro das pessoas apavoradas, quando a gente entrava nos lugares e só depois eu entendi que era porque era um homem com 4 crianças na década de 80 . Então essa análise eu só consegui fazer depois. Apesar do machismo ser estrutural, o meu pai já tinha uma visão um pouco diferente [...] ele tentava não diferenciar, tanto a mim quanto às tarefas que cabiam aos meus irmãos: cuidar da casa, da própria cama, então isso também sempre foi cobrado dos meus irmãos. Eu não ficava com a tarefa doméstica porque eu era mulher, isso praticamente não aconteceu, a gente dividia as coisas por todo mundo. Essa diferenciação dentro da minha casa pouco houve, não vou dizer que não houve, porque eu acho impossível, como a gente vive estruturalmente numa sociedade machista, não é que não houve, mas sempre existiu uma reflexão acerca disso e uma prática também tentando se voltar para essa reflexão. (Armanda).

No decorrer das observações do movimento sindical, reparei que as atitudes e falas de Dandara e Armanda são marcadas por essas reflexões sobre gênero e poder; seus posicionamentos são fruto do modo como foram educadas na infância, somado a influências de outros grupos sociais e leituras, aos quais tiveram acesso e sobre os quais falarei mais adiante. Ambas criticaram o machismo em diversas situações ocorridas dentro do movimento sindical, enquanto eu estava em campo. Trago, a seguir, uma dessas situações:

\begin{abstract}
Hoje, na assembleia, discutíamos a extensão da licença aleitamento. Uma professora propunha que fosse garantida à mãe a extensão da licença após o aleitamento com $50 \%$ da remuneração, para que as servidoras pudessem desfrutar de mais um tempo com seu bebê, caso optassem por isso. Armanda tinha diferença, queria a extensão da licença, sem, porém, "dar ideia ao governo de reduzir salário". O debate seguia entre as duas, e a mesa encaminhou regime de votação para a plenária, até que um professor homem pediu "questão de ordem", expondo seu ponto de vista, contrário ao das duas, pondo fim à discussão. Toda a plenária, composta por maioria feminina, o aplaudiu com fervor. Armanda demonstrou profunda irritação, pois segundo ela, toda aquela circunstância de domínio da fala do homem sobre a das mulheres em uma questão que toca exclusivamente à ala feminina do movimento, caracterizava "uma ação de opressão machista, apoiada e reproduzida por todas as mulheres que o aplaudiram.” (Diário de campo, 04/04/2017).
\end{abstract}

Excetuando os casos de Armanda e Dandara, que vivenciaram uma experiência mais liberta de constrangimentos impingidos à mulher desde a infância, os relatos apontam marcas de um tempo/sociedade em que à mulher estava destinado um lugar de submissão e domesticidade, também revelados na ocupação das mães: "do lar”, auxiliar de serviços gerais, costureira, caixa de supermercado, balconista, doméstica, cuidadora de idosos, bordadeiras, auxiliar de enfermagem, operária, de modo geral, de menor prestígio social que a dos pais: bancário, relojoeiro, agricultor, pequeno comerciário, policial militar, cobrador, caminhoneiro, etc. 
Ferreira (2008) e Vianna (2001) chamam a atenção para as possíveis desigualdades de gênero dentro do movimento sindical. Para essas autoras, as relações de gênero ainda são pouco exploradas em trabalhos sobre organização docente.

Quanto ao sindicato docente, é curioso investigar que identidades e representações de gênero nele circulam e se nele se apresenta esse viés de masculinidade hegemônica que caracteriza o sindicalismo em geral, sem, no entanto, naturalizar os sindicatos como espaços masculinos, porque neles "há outros sistemas de privilégios e exclusões tais como raça/etnicidade, idade e preferências sexuais que também filtram a participação no poder. (Castro, 1995 apud Ferreira, 2008, p. 24).

Além da influência das questões de gênero na educação familiar, foi interessante perceber também o papel da família na formação política dos seus filhos, através da transmissão de valores pelos diferentes graus de envolvimento aversão ou apatia - na política local e nacional.

[...] a família da minha mãe é muito militante, durante a ditadura militar foram os meus tios... Eles participavam do grêmio no Colégio Pedro II do Engenho Novo, o meu tio foi preso político, depois foi filiado ao PT. A maioria dos meus tios foram filiados $^{\text {(sic) }}$ ao PT e a minha formação política vem daí. O meu pai não tem uma atuação tão política assim, partidária, organizada, mas ele tem uma consciência política também. Então foram essas duas formações políticas que eu tive. (Armanda).

Era [o pai] do sindicato dos bancários. Aí já começou... [risos]. Não era exatamente diretor, mas tinha alguma coisa que falava... Eu não me informei muito bem, mas alguma coisa assim de delegado. Tinha umas outras nomenclaturas, mas ele fazia parte do sindicato. (Tarsila).

Na minha pré-adolescência, na época de associação de moradores, o meu pai sempre participou de tudo e eu comecei muito cedo a ir com o meu pai. Ele participava de todos os movimentos da associação de moradores, tinha ações também dentro da igreja, tinham ações sociais e ele participava. A minha mãe ia para as comissões de saúde no Rio, pedir postos de saúde, a gente pedia saneamento paras ruas, limpeza [...]. Meu pai sempre à frente de tudo e, como ele achava... Ele valorizava a mulher participando, eu sempre fui em tudo também. A minha mãe também, trabalhava sempre fora, mas sempre conseguia um tempo... Participou do clube de mulheres e, então, muito cedo eu comecei na associação de moradores aqui no bairro, junto com o meu pai, junto com a minha irmã, junto com a minha mãe... (Elis).

É interessante destacar algumas contradições nas relações familiares, como por exemplo, no relato de Elis, cuja divisão de tarefas domésticas tinha caráter bastante sexista. No entanto, a participação feminina na política local era encarada com naturalidade, e até mesmo incentivada pelo pai, diferente do observado nas famílias de Clarice e Francisca, cuja aversão à política e a subtração dessa expressão 
através da manipulação do voto, respectivamente, foi vivenciada ao longo da adolescência e superada posteriormente na vida adulta:

Na minha casa, nós votávamos em quem meu pai mandava e o meu pai mandava votar nos políticos de direita, tanto que o meu irmão, o único filho homem é de direita também, até hoje ele é de direita. Então, na minha casa, todos votavam em quem meu pai mandava, que como eu já disse, ele achava, que sequer tínhamos que estudar: as mulheres tinham que cozinhar, cuidar da casa. (Francisca).

Na infância pouco politizada de Francisca, pesa também a questão do gênero, tendo em vista a postura patriarcal de centralidade do poder decisório sobre a figura do pai, e a discriminação das meninas, às quais ficaria reservado um papel subalterno de realização de atividades domésticas. De uma forma um pouco mais sutil, parece que esse modelo também se aplica ao caso de Clarice, cuja distinção de gênero toma forma de proteção contra a política, que no imaginário de uma sociedade machista, é campo apenas de homens. ${ }^{34}$

Eu lembro que lá em casa era proibido falar em CUT. Todas as vezes que eu falava alguma coisa em CUT, ele [o pai] ficava... Porque era uma maneira dele proteger a gente. Toda vez que ele viajava... Tem uma frase que virou jargão lá em casa: "não discuta futebol, nem política, nem religião com ninguém, hein?" [...] Depois que eu comecei a militância nos movimentos, ele tinha muito orgulho, mas, inicialmente, ele tinha muita preocupação, muito medo. [...] Dava propaganda sobre a CUT, a gente era quase proibido de ver. (Clarice).

Apesar das histórias políticas de Clarice e Francisca tratarem de um rompimento com alguns valores familiares, pois ambas se tornaram liderança sindical e política, relatos como o de Armanda, Dandara, Elis e Tarsila sugerem a influência da família na construção de estruturas que propiciaram aos sujeitos o engajamento que apresentam hoje.

Obviamente, não foi apenas a convivência familiar que determinou o envolvimento sindical, mas certamente fatores como o "capital familiar" e a "ética do trabalho" (Souza, 2010) transmitidos pela família, são relevantes para compreensão da trajetória desses professores que hoje atuam no sindicato docente e alguns deles também em outras frentes.

Iniciei esse capítulo com o objetivo de realizar uma breve apresentação dos entrevistados, destacando a razão da escolha e a importância de cada um deles para a pesquisa. Até aqui, busquei destacar alguns aspectos comuns que perpassaram sua história de vida, sobretudo no que diz respeito ao que emergiu dos seus relatos,

\footnotetext{
${ }^{34}$ Para mais informações sobre o tema da mulher na política, ler Pinto (2010).
} 
como questões ligadas ao território, escolarização, família, relações de gênero, trabalho, religião e politização. Esse conjunto de elementos dão algumas pistas sobre o pertencimento social desses sujeitos.

No capítulo seguinte, continuarei a analisar as trajetórias de vida dos entrevistados, abordando a formação profissional, o exercício do magistério e o ingresso no sindicalismo docente. 


\title{
3
}

\section{Do ingresso na docência à formação no espaço sindical}

\author{
A vida é um grande e monumental poema, \\ A minha luta são estrofes, são versos \\ Deste grande e monumental poema!
}

Solano Trindade

Neste capítulo, abordo o tema das trajetórias de formação percorridas pelos professores participantes do movimento sindical de Duque de Caxias, pautados na ideia de que "a construção da formação docente envolve toda a trajetória dos profissionais, suas concepções de vida, de sociedade, de escola, de educação, seus interesses, necessidades, habilidades e também seus medos, dificuldades e limitações." (Alvarado-Prada et al., 2010, p. 370).

Na primeira parte do capítulo, abordo a questão da escolha (ou não escolha) pelo magistério, contextualizando os fatores sociais e econômicos que interferem nesse processo. Também discuto a formação profissional, na modalidade Normal, apresentando as histórias vividas por esses professores no ingresso e no interior do curso. Na segunda parte, trato da formação de nível superior, destacando a rede de ensino, a oferta de vagas e as instituições frequentadas nessa etapa de formação. $\mathrm{Na}$ terceira, faço algumas reflexões sobre a formação continuada no campo da formação de professores. E, por fim, entro na questão da formação no espaço sindical, apontando dois tipos de abordagem observadas no Sepe/Caxias.

\section{1}

\section{"Escolha" pelo magistério e formação profissional}

Dedico esta seção a entender os percursos de escolha e formação profissional situando-os nas trajetórias de vida dos entrevistados. A escolha de uma profissão, o ingresso no ensino superior e a entrada no mercado de trabalho são marcos na vida dos indivíduos que exprimem de algum modo seus projetos, trajetórias pessoais e pertencimento social.

Para Velho (1994, p. 103), a ideia de projeto é resultado da interação entre o sujeito e a sociedade na qual ele vive: 
O projeto não é abstratamente racional, como já mencionei, mas é resultado de uma deliberação consciente a partir das circunstâncias, do campo de possibilidades em que está inserido o sujeito. Isso implica reconhecer limitações, constrangimentos de todos os tipos, mas a própria existência de projeto é a afirmação de uma crença no indivíduo-sujeito. A identidade, por conseguinte, depende dessa relação do projeto do seu sujeito com a sociedade, em um permanente processo interativo.

De acordo com esse pensamento, considerar escolhas implica compreender o campo de possibilidades em que o sujeito está inserido. No capítulo anterior, tentei trazer um pouco das origens familiares, os valores e condições materiais que apontam certos limites à trajetória profissional do grupo entrevistado.

Apesar das restrições impostas por condições objetivas de vida, Velho (1994) afirma que em uma sociedade complexa e heterogênea como a nossa, os projetos estão sujeitos a constantes reelaborações, que conduzem os indivíduos à reinterpretarem também sua própria biografia:

De forma aparentemente paradoxal, em uma sociedade complexa e heterogênea, a multiplicidade de motivações e a própria fragmentação sociocultural ao mesmo tempo que produzem quase que uma necessidade de projetos, trazem a possibilidade de contradição e de conflitos. Por isso mesmo, o projeto é dinâmico e é permanentemente reelaborado, reorganizando a memória do ator, dando novos sentidos e significados, provocando com isso repercussões na sua identidade. (p. 104).

Assim, entre os muitos fatores que levam à escolha por uma profissão (Nogueira, 2005), a opção pelo magistério se apresentou para alguns dos entrevistados como a "escolha do possível” (Bourdieu \& Passeron, 2014):

Como eu trabalhava com o meu pai, eu acabei fazendo meu ensino médio primeiro à noite, aí eu fiz contabilidade. E a minha irmã fez o curso Normal. Mas, depois, com a dificuldade do acesso à universidade, a única possibilidade nossa aqui, mais próxima era o curso de pedagogia... Eu comecei a fazer pedagogia, mais porque eu vi a minha irmã que já era professora, já exercia... Quando eu era criança, eu ficava dando aula para o... Eu tinha um quadro... Essa parte eu esqueci, né? Mas uma das coisas também que eu gostava muito de brincar era isso, eu tinha um quadro, naquela época era de giz... E aí eu ficava escrevendo, dando aula para o vento... (Nise).

Em outra parte de seu relato, além da irmã professora, Nise cita a possível influência da mãe na sua "opção" pelo magistério:

A minha mãe, por outro lado, ela sempre trabalhou em casa de família e ela teve a oportunidade, numa dessas famílias que ela trabalhou lá no Centro do Rio de Janeiro, até de voltar a estudar, mas como ela casou, ela não voltou para a escola e o sonho dela era ser professora e ela sempre falava isso pra gente. Então, eu não sei se por isso a gente acabou sendo muito influenciada. (Nise).

A questão do ingresso no campo profissional é tão complexa que no depoimento de Nise são apontadas três razões para a escolha do magistério. 
Primeiro, emerge a questão do trabalho e a limitação da oferta de vagas e opções de cursos em proximidade à sua casa. As sentenças "acabei fazendo meu ensino médio à noite" e "A única possibilidade nossa aqui, mais próxima, era o curso de pedagogia", demonstram o quão estreito era o leque de opções de formação profissional para ela. Depois, a narradora relembra o fato de brincar de escrever em um quadro de giz, como forma de encontrar em suas memórias um argumento que justifique sua (limitada) escolha. E, por fim, a influência da mãe que teve o sonho de ser professora frustrado pelo casamento.

Assim, está presente no relato de Nise "a ideia já do senso comum, de que a memória é seletiva, em parte se explica, por essa dinâmica dos projetos e da construção da identidade, que leva referências do passado a um processo permanente de des e reconstrução.” (Velho, 1994, p. 104).

O mesmo movimento de reconstrução de projetos e memórias ocorre na história de Rosa que a princípio expôs as limitações que a vida lhe impôs quanto à escolha da profissão extremamente relacionada à necessidade de ingresso no mercado de trabalho e, depois, fala do "encontro com a docência" que a permitiu, em um segundo momento de sua vida, a escolha por permanecer no magistério.

Meu primeiro contato mesmo com o magistério foi informal ainda com 14 anos e, acho que por conta dessa relação, aí acabei indo fazer a formação de professores. Aí, na época, fiz a formação de professores no Roberto Silveira ${ }^{35}$... Comecei a fazer graduação. [...] Eu costumo brincar assim, ótimo, eu me encontrei na profissão de magistério, mas se não tivesse uma emergência de me formar e trabalhar, eu poderia ter feito a opção por outra coisa. Gostava muito... Eu gosto de veterinária, eu gosto de direito, são outras profissões que eu acho que eu teria um bom desempenho, se não fosse uma emergência do magistério, é claro que eu me encontrei porque também é aquilo, tive tempo suficiente para mudar na profissão, como muita gente muda e hoje eu falo: "Não mudei de profissão porque eu me encontrei." Eu gosto, gosto dessa coisa de lidar com as pessoas, eu acho isso o máximo, eu acho o máximo você estar nesse espaço, convivendo com as pessoas, desde mesmo da minha sala de aula, até a convivência e ver como as pessoas vão mudando. Como a gente vai acumulando, e essa relação de gente mesmo, por mais estresse que dê, essa relação, mesmo dialética com o outro... Então assim, eu me encontrei no magistério, mas é claro que se você for olhar dentro de um contexto social é a primeira profissão, principalmente também porque te dá a possibilidade de sobrevivência. (Rosa).

$\mathrm{Na}$ fala de Rosa está patente a precocidade no ingresso no magistério pela via da informalidade, apontada também em outras trajetórias de vida analisadas por Lelis (1996, p. 82):

\footnotetext{
${ }^{35}$ Instituto de Educação Governador Roberto Silveira, situado no bairro 25 de agosto no $1^{\circ}$ Distrito do município de Duque de Caxias.
} 
A inserção antecipada na profissão vem relativizar em parte uma tendência à supervalorização do eixo formação profissional-trabalho pedagógico, pois diferente da crença bastante disseminada, a entrada necessariamente não ocorre após a passagem formal pelas agências formadoras de magistério como a escola normal e/ou cursos de licenciatura. Esta característica pode ser uma chave para compreender o campo da docência, um campo que encerra trabalho "a domicílio" onde a professora joga com a continuidade/descontinuidade do tempo de trabalho em função do seu próprio cotidiano. Um caso que admite o desenvolvimento de atividades sem a credencial exigida em outras profissões.

No caso de Rosa, essa inserção antecipada ocasionada pela necessidade de ingresso no mercado de trabalho, foi decisiva para a continuidade de seu trajeto no magistério, apesar das outras habilidades elencadas por ela que poderiam tê-la conduzido a outras profissões.

A ideia de trabalhar no domicílio surgiu para Elis, em um momento de desemprego, o ingresso no magistério pela via da informalidade a despeito de não ser formada, proporcionou os primeiros contatos dela com alunos com necessidades especiais, os quais ela viria a atender em outro momento de sua trajetória profissional:

Dei aula em casa também. Fui explicadora numa época desempregada, fui explicadora e adorava meus alunos e engraçado que hoje que eu trabalho na educação especial, eu fico assim, naquela época eu já tinha aluno especial e eu adorava. Achava muito bom, muito bacana trabalhar com eles. (Elis).

Para Carvalho (2013, p. 223), “o reforço escolar é uma ocupação predominantemente feminina, cujos sujeitos são tanto estudantes quanto profissionais da educação e até de outras profissões. Que praticam a atividade como 'bico'." Ainda de acordo com a autora, o magistério doméstico serve "de laboratório de iniciação à docência, de teste de vocação para algumas jovens", tendo assim influência sobre a trajetória profissional dos sujeitos.

Para Mário, a falta de opções foi um fator decisivo na chegada ao magistério:

De dia você tinha ensino médio, Formação Geral e o Normal, a noite só tinha o Normal, então eu tive que fazer o Normal, mas não tinha, não me via apto, não achava que tinha vocação para o magistério e as pessoas sempre falavam que professor ganhava muito mal, era um discurso recorrente, que ganhava mal, que professor era uma profissão de passar fome, então eu não queria ser professor de forma alguma, tanto que, quando eu voltei pro Rio de Janeiro, eu fui trabalhar de teleoperador. [...] Fui trabalhar em Telemarketing porque eu não queria saber de educação porque não tinha nenhuma previsão de que isso [o magistério] fosse uma carreira que me desse algum futuro. (Mário).

Mas no percurso, Mário também ressignifica suas impressões sobre a profissão, tanto no plano do exercício do docente, quanto no que diz respeito à 
carreira e ele relata ter se "apaixonado" pela prática pedagógica desenvolvida por professores engajados de uma escola pequena, onde veio a ser inspetor de alunos:

Era uma escolinha simples, mas me apaixonei, os professores que tinham lá eram professores muito engajados na questão da educação, entendiam o seu o papel para formação daqueles alunos. Como era uma escola pequena, eu tinha uma intimidade muito grande com todo o corpo docente e discente, então me aproximei muito das pessoas, via aquela necessidade toda. Tinha uma professora, que eu não me lembro nem mais o nome dela, mas ela era professora de matemática, ela era uma professora daquelas que fazem você se apaixonar pela educação, ela amava o que ela fazia e ela conseguia transformar a vida dos alunos, então eu acabei me envolvendo muito, me interessei por lecionar. (Mário).

Além do encantamento com a prática docente de professores "muito engajados", ele também relata ter se surpreendido com o plano de cargos e salários do município de Duque de Caxias, o que o motivou a fazer o concurso e retornar à sua cidade natal:

Uma amiga minha, quando eu estava passando férias aqui no Rio, me falou: "Mário, você tem formação de professores, por que você não tenta o concurso?", aí eu falei: "Ganha muito mal", aí ela falou: "Olha só, não ganha tão mal assim não." Quando ela me disse aproximadamente o salário que, por exemplo, um professor de Caxias estava ganhando, eu disse: "Então, realmente tá ganhando mais do que eu como teleoperador e qualquer outro trabalho que eu estava fazendo." Valia a pena, até porque a carga horária me dava maior possibilidade de conseguir uma dobra ou uma segunda matrícula e melhorar a minha renda, porque dentro da camada social da qual eu faço parte, o salário que eu receberia como professor me manteria bem melhor do que como teleoperador, por exemplo, ou como inspetor escolar. Aí eu acabei optando por tentar, por minha sorte, passei no primeiro. Na primeira que eu tentei, passei no concurso de Caxias e fui atuar como professor na rede. (Mário).

Desse modo, ao se deparar com realidades que iam de encontro ao senso comum, o qual apresenta a docência como tarefa necessariamente mal remunerada e de difícil lida, Mário reconstruiu suas impressões sobre o magistério no plano material e simbólico, e passou a ver nessa carreira um horizonte profissional.

As limitações de escolha e ressignificação no contato com a profissão também apareceram no depoimento de Olga:

O magistério foi assim: eu, como todas as meninas, eu acho, sonhava em várias outras coisas, geralmente não ser professora. Eu queria ser bailarina, eu queria ser cantora, eu queria ser qualquer coisa, mas não achava que eu ia ser professora, e aí abriu lá no meu bairro uma Escola Normal. Isso, foi basicamente por isso. E quando eu comecei a estudar no segundo ano, eu tomei conhecimento de um projeto de alfabetização de adultos, chamava Cruzada $\mathrm{ABC}$, depois virou ABC Fluminense, que trabalhava com a ótica, pedagogia do Paulo Freire. Método de palavração e tal para as pessoas pobres mesmo, era para adultos trabalhadores. No segundo ano normal, eu comecei a trabalhar e eu me apaixonei, especialmente porque era alfabetizar pessoas adultas, que elas iam cansadas, mas, com muita sede de saber. [...] O projeto acabou e aí eu já estava com o pé na faculdade. Na faculdade, me deu 
de novo um dilema, mas aí já não era uma dúvida de ir para a escola, já achava que tinha que trabalhar na escola mesmo, aí já era se eu ia fazer pedagogia ou se seria professora de português. (Olga).

No caso de Galeano, cuja mãe era professora e também havia poucas opções de curso no ensino médio, antigo $2^{\circ}$ grau, a opção pelo magistério parece ter sido a mais cômoda:

Minha mãe era professora e eu, quando fui para o ensino médio, que na época era o segundo grau, eu tive que optar entre secretariado, formação geral e curso Normal. E eu, como a minha mãe era professora, então eu basicamente fui seguir o Normal. Até brincava com ela: "Ó, quando tiver que fazer alguma coisa, esses álbuns de seriado, a senhora me ajuda e tal." E eu fui seguindo o magistério... (Galeano).

Para Frida, a escolha do curso Normal foi estratégia adotada na tentativa de suprir carências de uma formação de nível fundamental, acelerada:

Como eu fiz supletivo, eu sempre tive muitos problemas de... Da questão ortográfica, português, é... Tinha muita dificuldade. Eu me lembro, que era... Supletivo, seis meses... Como você estudava a língua portuguesa de verdade? Já era muito limitado, aí eu pensei em fazer formação de professores porque na minha avaliação ia estudar muito mais português também, ia me ajudar, para estar me fortalecendo, pra cursar advocacia. (Frida).

No entanto, ela se surpreendeu ao descobrir que o curso não ofereceria um reforço nessa questão, pelo contrário, dadas as características do curso, algumas disciplinas não eram aprofundadas:

Na verdade, português você quase também não tinha, o que você tinha era Didática da Língua Portuguesa. [...] Então, eu fiquei com a mesma debilidade, só que eu me apaixonei pelo magistério, pela pedagogia, pelas disciplinas pedagógicas, me apaixonei, fiz concurso, entrei e... Eu acho que com essa coisa que eu já tinha da consciência de classe, é... Eu acho muito importante porque você... Para o magistério, eu acho fundamental, isso para tudo, para você estar formando o cidadão crítico, ajudando a formar cidadãos críticos, ainda mais na rede pública, que quem estuda é o filho do trabalhador. Então, você tem que ter essa consciência de classe, você tem esse compromisso. (Frida).

Apesar dessa frustração, houve uma grande identificação com o curso, pela possibilidade de unir seus conhecimentos políticos, advindos da participação no movimento estudantil e partido político, aos pedagógicos. Ao ingressar no magistério, Frida vislumbrou que poderia formar cidadãos críticos e ajudar a despertar a consciência de classe em seus alunos.

Tarsila, movida pela intenção de ser professora, fez o curso Normal, porém diante das dificuldades, quase desistiu, mas ao obter a aprovação para o curso de pedagogia decidiu continuar na área da educação. 
Eu ouvia os colegas comentando: "A gente tem que fazer prova para o CEFET." Aí, eu pensava: "Gente, isso não tem nada a ver comigo! Acho que o que tem mais a ver é formação de professores. Não sei, acho que eu vou gostar." Aí, eu fiz o Carmela Dutra $^{36}$, que é uma escola tradicional, e na época, ainda era prova. No final, no finalzinho, eu já não queria mais [risos]. Eu falei: "Ai, gente, acho que não vou conseguir, é muito difícil ou não tem a ver". Aí, eu tentei só para serviço social. Tentei, acho, que para UFRJ, para a Uerj, para mais uma que eu não lembro e para a Unirio, pedagogia. A única que eu passei foi pedagogia. Falei: "Poxa... Acho que vai ter que ser mesmo." Porque foi a única que eu passei. Aí fiz pedagogia e gostei. (Tarsila).

A despeito da convicção da escolha pelo magistério, as dificuldades encontradas no curso Normal, tanto no plano nas disciplinas, quanto nas normas rígidas da instituição, são relatadas por Francisca:

Eu quis ser sempre professora, foi uma opção minha, inclusive, quando eu estava no Instituto, que nós tivemos uma dificuldade no segundo ano em estatística, a minha adaptação passando de um colégio para o outro... Tinha um grupo de meninos, colegas que faziam engenharia e que ajudavam quem tivesse dificuldade, eles davam aula. [...] Estudei também nesse colégio particular e fiz o primeiro ano de curso Normal, aí fui fazer o segundo e o terceiro ano, terminei no Instituto de Educação, consegui uma transferência, na época, que se metia o dedo para baixar as bainhas e se desfazia as bainhas das saias e você voltava para casa com aquela bainha toda desfeita, naquela época. (Francisca).

A trajetória de formação de Cora se destoa das demais, porque primeiro ela iniciou a vida profissional em uma empresa voltada à educação profissional, onde trabalhou por 23 anos como auxiliar administrativo com apenas o antigo $1^{\circ}$ grau. Foi nessa instituição que o magistério pareceu ser uma possiblidade profissional:

Como eu fui trabalhar numa instituição que tinha a ver com a aprendizagem, que era de ensino, eu acabei também me interessando por essa parte. E aí, fazendo pedagogia, para ingressar nessa área. (Cora).

Demitida dessa empresa e diante da iminência de alguns concursos na área da educação, ela lançou mão da estratégia de realizar um curso semipresencial de complementação pedagógica de nível médio, que em apenas quatro meses a habilitou ao magistério:

Quando eu saí, eu não tinha concluído a faculdade, eu não tinha um ensino médio que me permitisse fazer um concurso. Então, o que eu pensei: "Vou procurar se existe algum curso de complementação pedagógica que me permita fazer esse concurso, já que eu tenho o segundo grau, que complemente as disciplinas pedagógicas para que eu possa tentar o concurso na educação.” E aí me foquei nisso e consegui descobrir. [...] Era semipresencial. Você ia, pegava os módulos, ia para casa e estudava. [...] Eu comia aqueles livros. Só que eu não estudava em casa porque eu tinha toda a aquela situação, tinha criança pequena, tinha problema com o marido.

\footnotetext{
${ }^{36}$ Instituto de Educação Carmela Dutra, situado em Madureira, Zona Norte do município do Rio de Janeiro.
} 
[...] Eu passava o dia lá. Eu sei que em quatro, cinco meses, eu concluí. Eu fiz todas as provas. É didática da matemática, didática da ciência, didática da filosofia... Tudo. [...] E aí, assim que abriram as inscrições para o concurso, eu fiz para três municípios: Nova Iguaçu, Caxias e Belford Roxo. E eu paguei à vista esse curso, com o que tinha recebido da indenização. Não foi um gasto, foi um investimento que eu fiz. E fazendo a faculdade à noite, fiz o investimento nesse curso. Depois de ter pago esse curso, de ter feito, eu peguei o diploma, fiz a minha inscrição nos três concursos e fui aprovada nos três. (Cora).

Em que pese o inegável esforço de Cora em concluir o mais breve possível o curso técnico do magistério e seu empenho em galgar um emprego público que lhe proporcionasse maior estabilidade, seu relato nos leva a refletir sobre a fragmentação da formação do professor. Ainda cursando pedagogia, Cora se valeu da possiblidade de habilitação em nível médio, semipresencial. Portanto, de forma acelerada e pouco aprofundada obteve as credenciais necessárias para o ensino.

Nise também procurou um curso Normal de duração de um ano, mas, no caso dela, por sentir uma lacuna quanto à habilitação para o magistério das séries iniciais em seu curso de pedagogia, que apenas a credenciou para a orientação e supervisão educacional.

Eu me encontrei no curso de Pedagogia! Terminei a faculdade e como eu me realizei tanto, eu decidi achar um curso Normal, porque eu achei que estava faltando alguma coisa. Aí, eu fiz o curso Normal em um ano, foi a única escola que eu estudei pagando, porque eu precisava... Porque para mim, faltava aquilo. E não é como hoje, que você tinha a possibilidade de fazer pedagogia e já sair formada para dar aula nos anos iniciais. [...] Isso que eu não abria mão, e aí me formei... Fiz em um ano, estudava muito, continuava trabalhando em comércio com o meu pai de dia e estudava à noite, ia, voltava de Bonsucesso - fiz lá na UNISUAM -, 11 horas da noite. Às vezes, me pergunto como é que eu fazia isso, pegava o ônibus na Avenida Brasil 11 horas da noite, voltava de trem 11 horas da noite. [...] Quando eu terminei esse curso, aí eu voltei, fiz a pós-graduação já também, foi a primeira turma de pós da FEBF, foi a que eu fiz. Então, assim, foi tudo muito rápido, foi indo muito rápido. E logo depois eu já fiz o concurso em 90, passei logo na primeira também. Então, foi muito assim, foi tudo muito rápido. E como eu era uma aluna dedicada, aí eu fui passando... Enfim, aí entrei na prefeitura. (Nise).

Armanda, não cursou o Normal; graduou-se em pedagogia pela Uerj e durante cinco anos realizou treinamentos no setor de recursos humanos de empresas privadas. Ela fala da difícil transição do mundo coorporativo para a escola:

Eu me formei em 2005, mas eu não fui para a sala de aula de escola, eu fui trabalhar em RH que eu já tinha começado desde o estágio, eu continuei até 2010, cinco anos mais ou menos na empresa privada onde eu trabalhava. [...] Fiquei na área primeiro de desenvolvimento, que é treinamento, educação coorporativa, e depois eu ampliei, fiz pós-graduação em gestão de pessoas e aí eu fui fazer de tudo, departamento pessoal. [...] Quando eu cheguei na educação eu lembro que uma das coisas mais impactantes para mim foi o diário [risos]. Porque eu nunca tinha visto aquilo na minha vida... Quer dizer, eu tinha visto na mão dos meus professores, mas eu, aberto 
o diário? Como que se preenchia? Como eu entrei sozinha no concurso não teve uma orientação, um treinamento, nada dessas... E eu já estava extremamente acostumada na empresa. Na empresa, você tem um treinamento e era eu quem formulava esse treinamento, então... Eu caí muito de paraquedas. Como assim? Não tem... Cadê? Eu começo por onde? Eu faço o quê? Então, eu entrei na sala e não sabia... Planejamento, plano de aula... Nada disso. (Armanda).

Armanda relata que, no princípio, a procura pelo curso superior em pedagogia estava voltada à área de desenvolvimento profissional, no setor de RH em empresas e não à educação escolar. Ao ser perguntada sobre o horizonte da docência em sua vida, afirmou que embora não se imaginasse professora, a presença de várias docentes em sua família a puseram em contato com a profissão antes mesmo da escolha pelo curso:

É... Eu não pensei assim... Eu sempre atuei, porque, assim, minha família tem professores. Minha tia que ajudou a me criar era professora no município do Rio. Então, eu sempre estive no meio, mas nunca percebi que eu estava [risos]. Então... É... Pensar que eu ia para a sala de aula algum dia, eu não tinha pensado mesmo. (Armanda).

A trajetória de Elis em busca de uma formação foi longa. Sempre presente como uma possiblidade, o magistério "rondou" a sua vida, até que diante das circunstâncias ela cedesse à profissão a qual parecia estar "destinada". Inicialmente, ela resistiu, tendo que abrir mão de seu emprego e da bolsa de estudos que seu patrão lhe oferecia, por não aceitar a imposição do curso:

Ele [o patrão] queria escolher a minha profissão. E eu não queria ser professora. Aí eu vim para a escola estadual, voltei para casa, foi uma loucura até eu tomar essa decisão porque eu tinha medo. [...] Tinha medo porque voltar para casa... E a falta de dinheiro? Então, foram dois anos de muito sofrimento até eu criar essa coragem e ter o apoio em casa, aí eu vim para casa, tinha 17 anos. (Elis).

O sonho de Elis era ser química e, para isso, ela foi procurar um curso em nível médio profissionalizante. Mas com uma reprovação em período de transição do ensino técnico da modalidade médio profissionalizante para "pós-médio", o curso foi descredenciado e ela ficou sem sua habilitação.

Era apaixonadíssima por química. Depois, eu descobri que eu sou muito ruim em química, aquelas letras, aqueles carbonos, aquelas cadeias são coisa de louco. [...] Eu queria trabalhar dentro da indústria, de laboratório mesmo, e esse curso era o início. Os professores falavam assim: "Vocês serão lavadores de vidro em laboratório", só que nem isso eu fui certificada porque aí o MEC no ano seguinte disse que o curso não seria habilitado, eu recebi um certificado de conclusão do segundo grau, só! Sem nenhuma menção a química. Sofri, chorei... A turma que formou antes de mim, conseguiu. Aí, minha frustração me paralisou um pouco, minha frustração, falta de dinheiro... Porque para eu fazer esse curso em Caxias, era caríssimo, caríssimo! [...] Eu fiquei muito frustrada, chateada, desanimada, triste, 
mas aí fiquei fazendo cursinho aqui, cursinho ali, auxiliar de escritório, datilografia... Aí parei, mas, sempre: "Vou fazer a minha faculdade, um dia vou fazer a minha faculdade." (Elis).

Assim como coloca Velho (1994), Elis reelabora tanto suas memórias - ao dizer que depois de ter seu sonho frustrado, descobriu ser "ruim em química" -, quanto seus projetos ao partir para um novo plano profissional fora do magistério:

Depois eu queria biologia, mas eu queria biologia não para o magistério, para pesquisa. [...] Na época, alguns colegas do trabalho riam porque na época faculdade só fazia quem tinha uma situação financeira mais ou menos ou, no mínimo, quem era muitíssimo inteligente, que não era o meu caso; e aí poderia fazer federal porque não trabalhava durante o dia e eu não tinha esse QI tão elevado e eu precisava trabalhar, não tinha como eu não trabalhar, eu fazer uma faculdade, assim, simplesmente não trabalhar, não havia essa possibilidade. Na época, não tinha à noite, era só integral, mas eu falava: "Um dia eu vou fazer a minha faculdade." (Elis, grifo meu).

Depois de muito resistir, Elis, por força dos condicionantes sociais, decide

fazer o curso de Formação de Professores:

Aí, me casei e sempre só cursinho, cursinho, cursinho, nunca, na verdade eu nunca tentei faculdade pública, isso porque eu não conseguia visualizar nenhuma possibilidade, mas nenhuma, nenhuma de parar de trabalhar, não tinha como, eu trabalhava para ajudar em casa, para ajudar a sustentar a minha família. Não existia, assim, a menor chance... Aí, me casei, tive meu filho, aí falei: "Vou fazer faculdade." Depois que o meu filho nasceu, quer dizer, as coisas foram ficando cada vez mais apertadas no mercado de trabalho e aí a minha irmã já estava no magistério, o magistério sempre rondou a minha vida, a minha família, aí eu falei assim: "Eu vou fazer formação de professores." Eu tinha, então, uns 28 anos. (Elis).

Como já possuía o ensino médio, Elis busca um curso que complemente sua formação, habilitando-a ao magistério, e encontra uma complementação semipresencial, semelhante à de Cora:

O aluno tinha o ensino médio, ele concluía em um ano, um ano e meio mais ou menos a formação de professores, aí vinham as matérias, as outras matérias relacionadas à formação de professores e aí eu fiz... Muito boa, era assim uma vez por mês em Petrópolis ${ }^{37}$, um final de semana, só que, assim, integral, sábado, o dia inteiro, domingo, o dia inteiro e com módulos, então, você trazia os módulos pra casa e nesse final de semana, você dava conta desse módulo, encerrava, tirava as dúvidas e fazia as provas. Era, assim, um nível muito bom, tinha para primeiro segmento, que eu fiz, e tinha também matemática e ciências, só que eu não quis fazer porque aí eu achei... Eu pensei assim: "Ah, eu acho que o que você faz em quatro anos de graduação, fazer em seis meses..." Aí, eu já não quis assim. (Elis).

Passado um longo período afastada dos estudos Elis consegue chegar à faculdade. Ao escolher o curso avalia o mercado de trabalho levando em

\footnotetext{
${ }^{37}$ Município da Região Serrana do Rio de Janeiro, vizinho a Duque de Caxias.
} 
consideração sua idade, a necessidade de um retorno financeiro imediato e o fato de não dispor de tempo para frequentar um curso integral. Elis adapta seu projeto inicial de cursar bacharelado em biologia ao curso de licenciatura, prosseguindo, assim, no magistério.

A faculdade quando veio, eu já tinha os meus dois filhos, e aí tinha que decidir o quê que eu ia fazer; o sonho de bióloga já tinha ficado para trás por conta da minha idade e, de novo, a situação financeira, porque eu não podia entrar para o mercado, fazer estágio, concorrer e tentar estágio - meu sonho era ir pra Fiocruz fazer estágio. [...] Mas aí, eu, com dois filhos, tinha que trabalhar, tinha que trazer dinheiro para casa, como é que eu ia me submeter a um estágio que ficava assim seis meses sem receber nada, quando recebia era uma bolsa, na época, nem sei quanto. [...] Aí, eu parti para o magistério, falei assim: "Não, eu vou fazer biologia, mas licenciatura." E até porque, ainda era magistério um dos poucos ramos que a idade não te prejudicava, não tinha essa concorrência. E aí eu fiz biologia. (Elis, grifo meu).

Devido à necessidade de conciliar trabalho e estudo, Clarice frequentou o

Normal na rede privada de ensino, onde o curso era oferecido no turno da noite.

Hoje, como professora formadora de professores, avalia a precariedade de sua formação inicial:

Não pude fazer o Roberto Silveira, porque eu tive que trabalhar para ajudar em casa. Era o meu sonho ser aluna do Roberto Silveira, eu não pude ser. Porque o Roberto Silveira só tinha Normal à tarde e eu trabalhava durante o dia, para pagar a minha escola à noite, porque eu queria fazer faculdade. Eu tinha que fazer faculdade. Eu não queria parar, porque eu queria ser professora, eu queria fazer faculdade para orientadora educacional. Então, foi quando eu fui para a escola particular. $\mathrm{O} 1^{\circ}$ ano do básico, no médio, foi no Cruzeiro do Sul ${ }^{38}$. De lá eu fui para o Normal com a minha madrinha que era professora no Auri Verde, aí o Auri Verde ${ }^{39}$ faliu. [...] Aî eu fiz o $3^{\circ}$ e $04^{\circ}$ ano no Duque ${ }^{40}$ particular. Muito precária a minha formação inicial. Não fiz estágio, era tudo na camaradagem, na malandragem. Assinavam, porque eu trabalhava. Foi muito precário, muito mal feito. (Clarice).

Mediante essa formação e as condições econômicas da família, outra barreira

a ser transposta seria o vestibular para o ingresso na universidade:

Eu trabalhava durante o dia, chegava em casa, ia até de madrugada estudando minhas apostilas do ensino médio, para poder fazer a prova. Aí, ia no dia seguinte fazer a prova, saía da prova do vestibular lá na Uerj, pegava o ônibus sofrível, ficava sem almoçar, ia para o trabalho. Foi essa rotina durante uma semana de prova. Era tão sofrível, que um dia eu chorei, chorei, chorei. E eu lembro de uma imagem: eu na Uerj, esperando a hora para entrar para fazer a prova do vestibular e um monte de garota, chegando de carro particular com os seus pais. Aquilo era uma dor para mim, porque eu não tinha aquela organização de vida. É... Mas eu só sei te falar que eu passei em segundo lugar. E com toda a precariedade. Mas eu estudava sozinha.

\footnotetext{
${ }^{38}$ Educandário Cruzeiro do Sul - rede privada de ensino de Duque de Caxias, $1^{\circ}$ Distrito.

${ }^{39}$ Colégio Auri Verde - rede privada de ensino de Duque de Caxias, $1^{\circ}$ Distrito.

${ }^{40}$ Colégio Duque de Caxias - rede privada de ensino de Duque de Caxias, $1^{\circ}$ Distrito.
} 
Sozinha que eu digo, eu não fiz pré-vestibular, o ensino médio foi muito fraco. (Clarice).

Nogueira (2005, p. 1) alerta para a impossibilidade de uma explicação unilateral do complexo processo de escolha do curso superior, chamando atenção para uma série de fatores de natureza macrossociológica e individual.

Se partirmos de uma abordagem macrossociológica, é possível descrever uma série de condicionantes do ato de escolha individual: 1) a posição social objetiva dos sujeitos que escolhem (volume e peso relativo dos seus capitais cultural, econômico e social); 2) a estrutura de oportunidades do sistema universitário (cursos e faculdades definidos em termos do seu grau de prestígio acadêmico, localização, custos financeiros envolvidos, horários das aulas, natureza e grau de dificuldade dos cursos e de seu processo seletivo); 3) as características do mercado de trabalho (natureza do trabalho, grau de prestígio e retorno financeiro médio associado a cada profissão).

Outra forma de análise também sugerida pelo autor supracitado seria a partir do próprio indivíduo que escolhe:

Se partirmos, ao contrário, do próprio indivíduo que escolhe, é possível, analiticamente, caracterizá-lo como possuindo: 1) determinados gostos ou preferências relativos às áreas do conhecimento e aos campos profissionais a elas associados; 2) um conjunto de aspirações, expectativas e projetos de vida (de curto, médio e longo prazo) que o fazem priorizar, por exemplo, conforme o caso, a estabilidade, o retorno financeiro, o prestígio ou o tipo de sociabilidade supostamente associados a cada curso ou profissão; 3) um conjunto de representações sobre si mesmo, relativas não apenas à sua capacidade intelectual, mas às suas habilidades em geral; 4) um conjunto mais ou menos amplo de informações sobre o sistema universitário, os diversos cursos e as futuras profissões. (p. 1).

Para Zilda, o ingresso no magistério, foi "uma aposta" no escuro, diante da

indecisão quanto à escolha do curso de graduação a ingressar ainda aos 17 anos:

Eu lembro que na época de vestibular, eu só via muito o que eu não queria. Mas, o que eu queria, eu não sabia muito. A pedagogia foi meio que uma aposta no escuro, que deu certo. Eu me apaixono pelo curso logo no início. E sou apaixonada até hoje por essa área. (Zilda).

Antes de cursar pedagogia, Dandara buscou a habilitação para o magistério através do curso Normal, mesmo já possuindo a formação geral de nível médio:

Em Souza, na Paraíba, eu estudei o Normal, eu já tinha feito o ensino médio, mas lá eu fiz o curso Normal, aí quando eu voltei pro Rio de Janeiro, em 91, aí eu falei: "Vou continuar estudando." [...] E no pré-vestibular, um professor de história porque eu queria fazer história, eu não queria fazer pedagogia - me aconselhou a fazer pedagogia, falou: "Se você fizer pedagogia, você tem mais chance de entrar pra uma pública do que se você fizer história." [...] Eu passei pra UFF no primeiro semestre, em $92 \ldots$ Me apaixonei pela pedagogia. Não quis mais sair, falei: "Agora eu quero ser professora". (Dandara). 
Desapontada com a dimensão muito técnica do curso Normal, Dandara pensa em abandonar o magistério, mas se redescobre professora ao entrar para o curso de pedagogia e visualizar a dimensão política da educação:

Eu ficava na dúvida, porque era muito técnico e algumas coisas eu não conseguia fazer. [...] "Ah, se for assim, eu não quero!" Mas, quando eu cheguei na pedagogia da UFF, eu me apaixonei porque eu vi o outro lado do magistério, magistério numa visão política mesmo e de defesa da escola pública. E me apaixonei pela pedagogia, fiquei na pedagogia. (Dandara).

Embora Dandara faça uma contraposição entre os aspectos técnicos e políticos evidenciados em sua formação para o magistério em nível médio e superior, respectivamente, Candau (2013, p. 55) chama a atenção para a multidimensionalidade da educação, em uma articulação entre as múltiplas dimensões e não sobreposição entre elas:

A educação é um processo multidimensional. De fato, ela apresenta uma dimensão humana, uma dimensão técnica e uma dimensão político-social. Estas dimensões não podem ser visualizadas como partes que se justapõem, ou que são acrescentadas umas às outras sem guardarem entre si uma articulação dinâmica e coerente. Não se trata de propor um ecletismo ou associar de forma meramente superficial elementos oriundos de diferentes perspectivas. O desafio está exatamente em construir uma visão articulada em que, partindo-se de uma perspectiva de educação como prática social inserida num contexto político-social determinado, no entanto não são deixadas num segundo plano as variáveis processuais. Contexto e processo são vistos em articulação onde a prática educativa quotidiana, traduzida em comportamentos e atitudes concretos relativos aos objetivos propostos, disciplinas, avaliação, relação professor-aluno, etc., assume uma perspectiva política-social e esta, por sua vez, não se reduz a uma prática que poderíamos chamar, por não encontrarmos no momento outra expressão melhor, "paraprofissional", mas se concretiza no dia a dia da prática educativa.

No relato de Cecília sobre a escolha da profissão, aparece fortemente a questão do "chamado" em frases como "o magistério me escolheu". Suas palavras nos remetem a um modelo de magistério anterior à estatização no qual o "professor era o religioso, envolvendo a docência numa aura de vocação e sacerdócio, mesmo em se tratando de professores leigos.” (Lüdke \& Boing, 2004).

Eu não escolhi a educação, a educação que me escolheu. Eu fui escolhida desde criança, na minha vida inteira, eu disse que eu ia ser professora. [...] Quando eu terminei o nono ano, que na época era oitava série, a minha mãe já correu atrás de vaga pra mim porque meus pais não tinham dinheiro, não tinham como pagar um segundo grau, então, a minha mãe foi atrás de vaga no Instituto de Educação pra mim e aí ela pelejou, pelejou, pelejou até conseguir a vaga e aí eu fui fazer o Normal. [...] Eu terminei no terceiro ano Normal, no outro ano, eu já estava dando aula e já peguei alfabetização, então é... A minha vida inteira eu acho que eu não me vi fazendo outra coisa que não fosse o magistério, e olha que eu sei fazer outras coisas. [...] Eu fazia festa, ornamentava painel, toalha de mesa, baleiro, fazia toda a festa dos 
outros e eles falavam: "Ah, Cecília você tem que montar uma empresa", isso não é o meu chamado, o meu chamado é para o magistério! Eu faço muitas outras coisas, mas dar aula, não tem como eu abrir mão. (Cecília).

Assim como Cecília, entre as professoras entrevistadas por Lelis (1996), um grupo relatou ser vocacionado para o magistério, com uma visão bastante positiva sobre o curso Normal, ao que a autora analisa:

"Vocacionadas" para uma profissão considerada adequada a uma geração, a uma classe social, e ao gênero feminino, essas mulheres talvez só poderiam responder destes modos à experiência como normalistas, pois seus gostos e preferências foram sendo construídos no interior de um campo familiar, de um campo social, com determinadas características e não outras. (p. 101).

Como visto, nos relatos aparecem diferentes percursos de entrada no magistério, tanto no que diz respeito às motivações para a escolha da profissão, quanto ao curso de formação frequentado.

De um modo geral, as principais motivações para a escolha do magistério estavam relacionadas à origem social dos indivíduos que lhes impunha a emergência da remuneração para sustento próprio e das suas famílias. Nesse contexto, o curso Normal atendia essas expectativas, pois permitia a profissionalização de nível médio e o acesso a uma profissão dita "flexível e acessível" quanto ao horário e o mercado de trabalho, inclusive podendo ser exercida na informalidade.

Nessas trajetórias, fica aparente o quadro da fragmentação do magistério, pela permanência da formação de professores em nível médio e sua coexistência com outras formas de ingresso na docência, seja nas licenciaturas ou nos cursos de complementação pedagógica.

É possível listar uma série de aproximações entre essas trajetórias: 1) quase todas de ascensão social em relação à escolarização, ocupação e remuneração dos pais (ver capítulo 2); 2) para maior parte dos entrevistados a docência não foi uma escolha deliberada, mas um caminho possível a ser seguido; 3) a formação inicial se deu concomitante ao trabalho ou em função dele; 4) a relação com o magistério foi ressignificada a partir de determinadas experiências de formação e de docência.

Para além dessas convergências, é possível apontar algumas distinções entre os percursos de formação e a forma como são relatados pelos narradores.

A primeira questão a destacar é a maneira como cada professor conta sua história e ressignifica seu ingresso na docência. Os relatos vão da mais insistente 
resistência, até certa idealização da docência. Passando também por abordagens mais críticas ou realistas, como os relatos de Rosa e Cora, que aproveitam a entrevista para fazer uma análise de seu percurso no magistério a partir de sua condição social, apontando, inclusive, as dificuldades enfrentadas, as restrições de seu campo de possibilidades e readaptações de projetos em função dele:

\begin{abstract}
A maior parte da minha trajetória, tirando a alfabetização, a maior parte foi na escola pública, aí estudei no Frei Henrique ${ }^{41}$, que é ali na Figueira, depois no Roberto Silveira. Na graduação, iniciei na UFF, matemática na UFF, mas era aquela loucura, trabalhava em Caxias, trabalhava em São João e ia estudar em Niterói. [...] Para além da distância, do cansaço, não conseguia acompanhar algumas disciplinas, não conseguia de jeito nenhum, e aí eu fiquei um ano e meio e tranquei, depois voltei, aí, depois, tranquei e falei: "Vou trancar, não estou conseguindo dar conta de trabalho, de estudos..." E aí eu vim pra Feuduc ${ }^{42}$, terminei matemática na Feuduc, sendo que nunca exerci. [...] Eu gosto de matemática, mas acabei enveredando pela educação especial e aí veio a prática mesmo, trabalhando com educação especial. Depois, fiz a especialização em educação especial e um outro elemento que influenciou foi que eu acabei não avançando nos concursos para matemática. [...] No último concurso, eu tomei a decisão que eu não ia fazer para matemática porque eu estou muito envolvida com a educação especial... Inclusive, já dei todos os meus livros de matemática. [...] Agora, só tem literatura de educação em educação especial, que inclusive é o que eu quero fazer no mestrado. (Rosa).
\end{abstract}

A segunda questão são as diferentes formações iniciais que propiciaram o ingresso na docência. Curso noturno, no caso de Mário; curso de complementação pedagógica de nível médio em módulos, nas trajetórias de Nise, Cora e Elis - destas duas últimas, semipresencial; curso Normal na rede privada, para Clarice e Frida; rede pública e privada para Francisca. Colégio estadual, no caso de Galeano; e curso Normal "tradicional", em institutos de educação, na formação de Rosa, Cecília, e Tarsila, tendo esta última se submetido à prova para ingresso.

Apenas as professoras Zilda e Armanda não ingressaram no magistério por formação de nível médio. Armanda relata ter sentido falta, ao iniciar na docência, das habilidades de "caráter técnico" que, segundo ela, poderia ter aprendido no curso Normal:

Eu não fiz o Normal, aí eu senti um impacto muito grande. Porque as questões burocráticas do dia a dia, na faculdade a gente não vê. A faculdade, ela tem um perfil mais reflexivo de questionador das metodologias e não estudar metodologias, então, a gente tem mais um... Pelo menos na minha formação. O caráter era mais de reflexão sobre as questões da educação do que estudar a própria metodologia. Então, eu senti esse impacto. (Armanda).

\footnotetext{
${ }^{41}$ Colégio Estadual Frei Henrique de Coimbra - localizado no bairro Figueira, $2^{\circ}$ Distrito de Duque de Caxias.

${ }^{42}$ Fundação Educacional Duque de Caxias.
} 
As Escolas Normais foram criadas no século XIX, destinadas à formação de professores de "primeiras letras", inaugurando o que seria uma formação específica para o professor, quando ainda o acesso à escolarização era bem escasso no país. Já nas primeiras décadas do século XX, com o início da industrialização no país, pensou-se em novos modelos de formação para o professor. Ao longo das décadas, se deram diversas discussões sobre a habilitação para o magistério de nível médio, que no bojo da elaboração das leis $n^{\circ} 4.024 / 61, n^{\circ} 5.540 / 68, n^{\circ} 5.692 / 71, n^{\circ} 7.044 / 82$ e $n^{\text {o }}$ 9.394/96 "nortearam a estrutura curricular dos cursos de formação de professores". (Gatti \& Barretto, 2009, p. 38).

Em 1971, a lei no 5.692 reformou a educação básica no Brasil e com ela a formação do professor de nível médio, sendo extintas as Escolas Normais e a formação que a elas cabia passa a ser realizada sob forma de uma habilitação do ensino de $2^{\circ}$ grau, chamada magistério. "Com essa mudança, a formação perde algumas de suas especificidades, dado que sendo uma habilitação entre outras, deveria ajustar-se em grande parte ao currículo geral do ensino de segundo grau." (Gatti \& Barretto, 2009, p. 38).

Em 1982, uma nova lei foi aprovada, mantendo a formação na Habilitação Magistério, porém com a introdução de outras opções formativas para os docentes do ensino fundamental, como as chamadas licenciaturas curtas, houve “contraposições de acadêmicos e entidades coorporativas, o que levou o então Conselho Federal de Educação (CFE), alguns anos depois, a emitir orientações normativas para tornar progressivamente plenas essas licenciaturas curtas." (Gatti \& Barretto, 2009, p. 40).

Com a lei $n^{\circ}$ 9.394/96, novas alterações ocorreram no âmbito da educação nacional, no entanto, as mudanças na formação de professores se dariam lentamente:

A estrutura curricular dos cursos de formação de professores ficou ainda com a marca da legislação anterior por um período relativamente longo, iniciando-se as primeiras adaptações de currículo a partir de 2002, quando as Diretrizes Curriculares Nacionais para a Formação de Professores são promulgadas, e nos anos subsequentes, quando diretrizes curriculares para cada curso de licenciatura passam a ser aprovados pelo Conselho Nacional de Educação. (Gatti \& Barretto, 2009, p. 42).

Considerando que os depoentes cursaram a formação inicial para o magistério entre os anos 1970 e 2000, em diferentes instituições, pode-se dizer que a educação recebida por eles sofreu as influências dessas reformas na formação de professores. 
Apesar dessas mudanças no âmbito da legislação que regula a formação de professores, no município de Duque de Caxias existem cinco escolas públicas que oferecem o curso Normal: o Instituto de Educação Governador Roberto Silveira (25 de agosto), o Colégio Estadual Alexander Graham Bell (Jardim Primavera), Colégio Estadual Fernando Figueiredo (Imbariê), o Colégio Estadual Alfredo Backer (Imbariê) e a Escola Estadual Barão de Mauá (Xerém), os quais continuam a atender uma constante demanda de jovens pelo magistério em nível médio, afora escolas privadas que além do curso de formação de professores regular, oferecem a modalidade "pós-médio", atendendo a demanda de profissionalização de recémsaídos do ensino médio, professores que atuam no magistério sem as credencias necessárias, e os profissionais que buscam mudar de área de atuação.

\section{2 \\ Formação superior no município de Duque de Caxias}

Pelos relatos dos entrevistados, ficou claro que após o curso Normal, eles buscaram uma formação no ensino superior. Todos possuem licenciatura, exceto Mário que está com o curso de graduação em Pedagogia em andamento. Muitos cursaram também a especialização. Tarsila, Clarice e Zilda, são mestres em Educação pela Universidade Federal do Estado do Rio de Janeiro (Unirio), Universidade Federal Fluminense (UFF) e UFRJ respectivamente.

Analisando dados produzidos a partir de questionário aplicado aos professores da rede municipal de Duque de Caxias em assembleias durante a database de 2016, é possível destacar que a formação predominante entre os respondentes se deu no curso de licenciatura, mas que muitos professores também cursaram a formação de professores em nível médio e fizeram uma especialização posteriormente. De 213 respondentes, 120 fizeram o curso Normal; 155 cursaram licenciatura, sendo 73 em pedagogia; 122 possuem especialização e os cursos de maior frequência são o de gestão/administração escolar (20), orientação educacional (17) e psicopedagogia (16); 27 têm mestrado, 16 deles em educação; e 12 possuem ou estão cursando o doutorado, 9 deles em educação, conforme explicita o gráfico a seguir: 


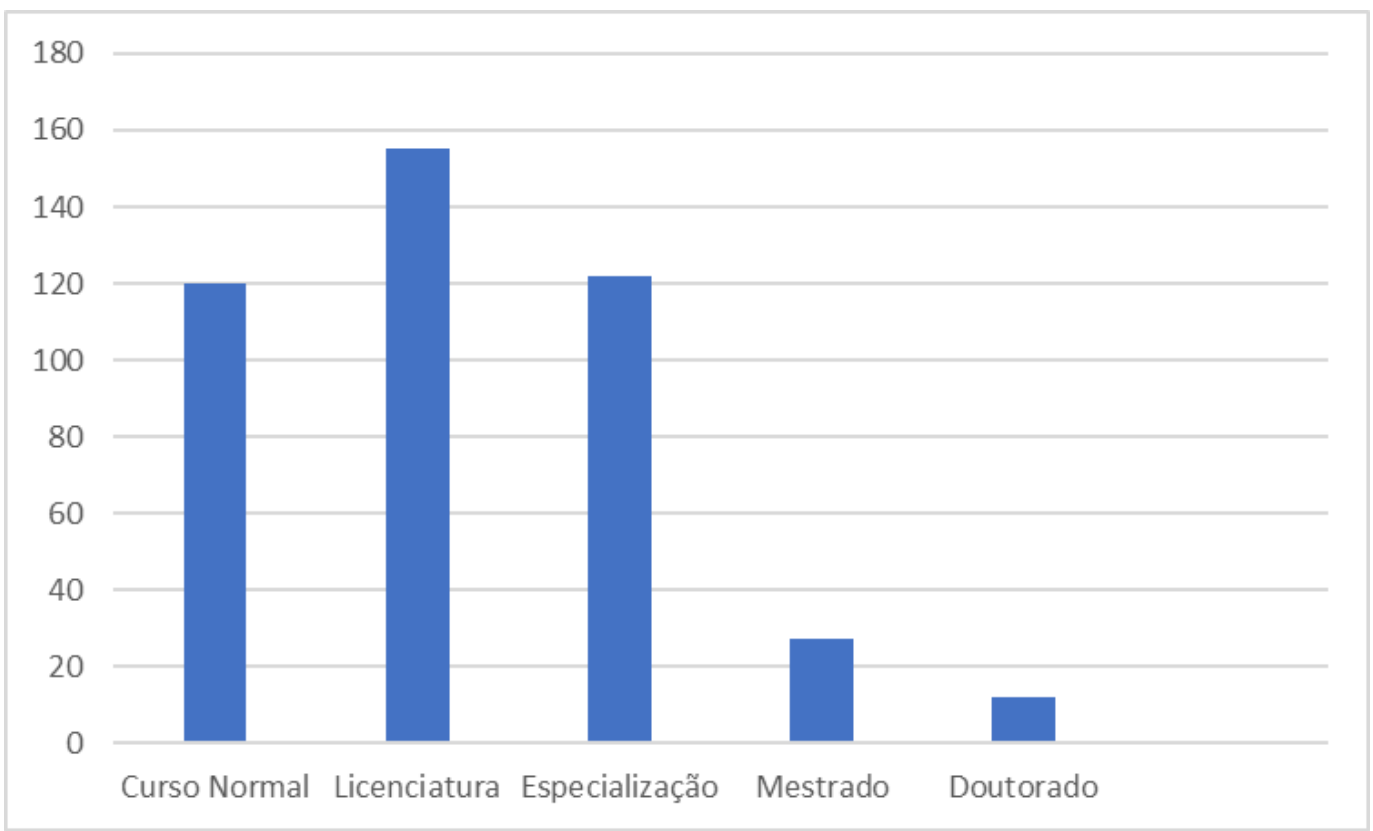

Gráfico 1 - Formação dos professores respondentes

Fonte: Elaboração própria.

É interessante também destacar a rede e instituição onde o curso superior foi realizado: 10 entrevistados cursaram a graduação em universidades públicas: Armanda, Cora, Nise, Mario, Clarice, Cecília, Zilda e Frida estudaram na Universidade Estadual do Rio de Janeiro (Uerj), Dandara na UFF e Tarsila na Unirio; 5 deles se formaram em universidades privadas: Galeano, Rosa e Elis, na Fundação Educacional de Duque de Caxias (Feuduc); Olga na Associação de Ensino Superior de Nova Iguaçu (Unig) e Francisca na Universidade Gama Filho (UGF).

Portanto, dois aspectos nos chamam a atenção sobre a formação superior desses professores: a permanência dessa alternância pública/privada observada no processo de escolarização dos narradores e o quantitativo de ex-alunos de determinadas universidades - dos 15 entrevistados, 8 estudaram na Uerj, 5 deles no campus da Baixada Fluminense; 3 estudaram em uma universidade privada do município de Duque de Caxias, a Feuduc.

Em um primeiro olhar, seria possível entender que a procura por universidades na Baixada, mais especificamente em Duque de Caxias, estaria associada à proximidade do domicílio e/ou local de trabalho dos sujeitos, já que, conforme relatou Nise, muitos deles tiveram poucas opções diante de suas condições materiais de existência. 
No entanto, a quantidade de ex-alunos da FEBF/Uerj e da Feuduc no movimento sindical também pode estar relacionada ao histórico dessas instituições junto aos movimentos sociais da cidade. Ao longo das observações, foi possível perceber uma relação de proximidade dessas faculdades com o movimento sindical de Duque de Caxias, especialmente a FEBF. Em ambas há determinados núcleos (professores e grupos de pesquisa) que realizam uma articulação entre o saber/espaço universitário e os professores do município e, por conseguinte, o seu sindicato.

A FEBF, "representação da Uerj na Baixada Fluminense", foi a primeira universidade pública a se instalar no município. Inicialmente ligada ao curso de Formação de Professores para o Ensino Normal e funcionando nas dependências do Instituo de Educação Governador Roberto Silveira (IEGRS), o único curso oferecido era o de graduação em pedagogia. Só após a Reforma do Ensino Superior de 1968, a Reforma do Ensino de $1^{\circ}$ e $2^{\circ}$ graus de 1971 e a fusão dos Estados do Rio de Janeiro e da Guanabara é que o curso foi incorporado à Uerj, como descrito no site da faculdade ${ }^{43}$ :

A história desta faculdade inicia-se em 1966, quando o Conselho Estadual de Educação do antigo Estado do Rio de Janeiro autorizou o funcionamento do curso de Formação de Professores para o Ensino Normal (CFPEN) no Instituto de Educação. Em 1971, o CFPEN passa a ser denominado Curso de Pedagogia, certamente em face do art. 87 da Lei Federal $n^{\circ}$ 5.692/71, que revogou, entre outros, o art. 59 da Lei de Diretrizes e Bases da Educação Nacional 4.024/61 que autorizava o funcionamento de CFPENs nos Institutos de Educação. Antes da Fusão dos Estados os diplomas expedidos por este curso, por ele estar situado na região do antigo Estado do Rio de Janeiro, eram chancelados pela UFF. Após a Fusão (1975) o Curso de Pedagogia perde esta vinculação com a UFF e continua vinculado à Secretaria de Estado de Educação, existindo um período de dúvidas com relação à continuidade do curso. Desde o início de sua trajetória, era um curso superior isolado onde toda interlocução dava-se no âmbito da Secretaria Estadual de Educação, funcionando com professores devidamente concursados e habilitados para o magistério oficial de $1^{\circ}$ e $2^{\circ}$ graus. (FEBF, 2017, s/pág.).

Nas memórias de Clarice como estudante da Uerj, no período de transição entre a vinculação com a Secretaria de Estado de Educação e o primeiro concurso docente como unidade independente, está a diferença entre o ensino prestado por aqueles cuja formação era adequada ao ensino superior e os professores "aproveitados" do ensino de $1^{\circ}$ grau:

Eu entrei na FEBF num período em que ela ainda não era Unidade Universitária, a nossa gestão no centro acadêmico teve isso como principal bandeira e a gente

\footnotetext{
${ }^{43}$ Disponível em: <http://www.febf.uerj.br/historico_novo_febf.html>. Acesso em: 12 out. 2017.
} 
conseguiu conquistar nesse período. Mas foi um período de transição na organização da futura unidade, quando começaram a chegar os primeiros professores da Uerj. Ela começou com o quadro do Estado. Só depois é que chegaram os professores concursados da Uerj. Então, eu peguei tanto professores do Estado, que em sua maioria eram muito ruins. [...] E peguei os primeiros professores concursados, que em sua maioria estavam vindo com muito gás, vindo com muita identificação com as questões da Baixada. Então, eu tive professores muito bons, logo no primeiro ano. (Clarice).

As mobilizações vividas por Clarice junto ao centro acadêmico fizeram parte da história de criação da FEBF:

O primeiro concurso docente realizado pela Uerj, para o então Curso de Pedagogia de Caxias, ocorre em 1985. Durante os anos pós-fusão ocorrem intensas mobilizações da comunidade acadêmica do Curso para a permanência deste em Duque de Caxias. Mas é por força da Lei 472 de 1981, sancionada pelo então governador do Estado do Rio de Janeiro Chagas Freitas, que o curso é incorporado a Uerj, em 1982. Porém, da incorporação resultaram as perdas de sua autonomia tanto administrativa quanto pedagógica. O Curso ficou subordinado à Faculdade de Educação da Uerj, configurando-se como um apêndice desta onde passou a ficar atrelada ao seu currículo e a sua coordenação. Finalmente, em 1988, como forma de reverter esta situação, cria-se a Faculdade de Educação da Baixada Fluminense como Unidade Acadêmica da Uerj pela Resolução 548/88 do Consuni. A partir de então se restabelece sua autonomia, mas desta vez como Unidade Universitária. Entre 1982 e 1998, mesmo já pertencendo a Uerj, a Faculdade continuou a funcionar no IEGRS apenas no período noturno em salas de aula cedidas por ele. A reivindicação por um prédio próprio já era uma bandeira de luta desde a década de 1980 que somada a falta de condições físicas para ampliação de suas atividades levou a comunidade da FEBF a aceitar sua transferência para o CIEP-090 na Vila São Luís, local em que funciona até hoje. (FEBF, 2017, s/pág.).

A tentativa de se fazer presente no município e seus laços com o sindicato ficam aparentes não apenas nos depoimentos dos professores militantes, que estudaram na instituição em diferentes fases da sua história, mas também nas observações realizadas. Uma série de atividades sindicais e formativas são desenvolvidas em conjunto com esta instituição, inclusive seu espaço foi bastante utilizado para realização de assembleias, conselhos e debates, durante a greve estadual e municipal do ano de 2016, e o adiamento do início do segundo semestre letivo de $2016^{44}$.

\footnotetext{
${ }^{44}$ O segundo semestre letivo de 2016, que seria iniciado em 17/01/2017, já com atraso em decorrência da greve ocorrida no ano anterior, teve seu início adiado cinco vezes por falta de condições estruturais. E só retornou às atividades em 10/04/2017, porém ainda em situação aquém das condições ideais de funcionamento. Mais informações disponíveis em: <http://www.uerj.br/comunidade/arquivos/ca2016/CA_2016_UERJ_atualizado_20160901.pdf>. Acesso em: 3 jun. 2017.
} 


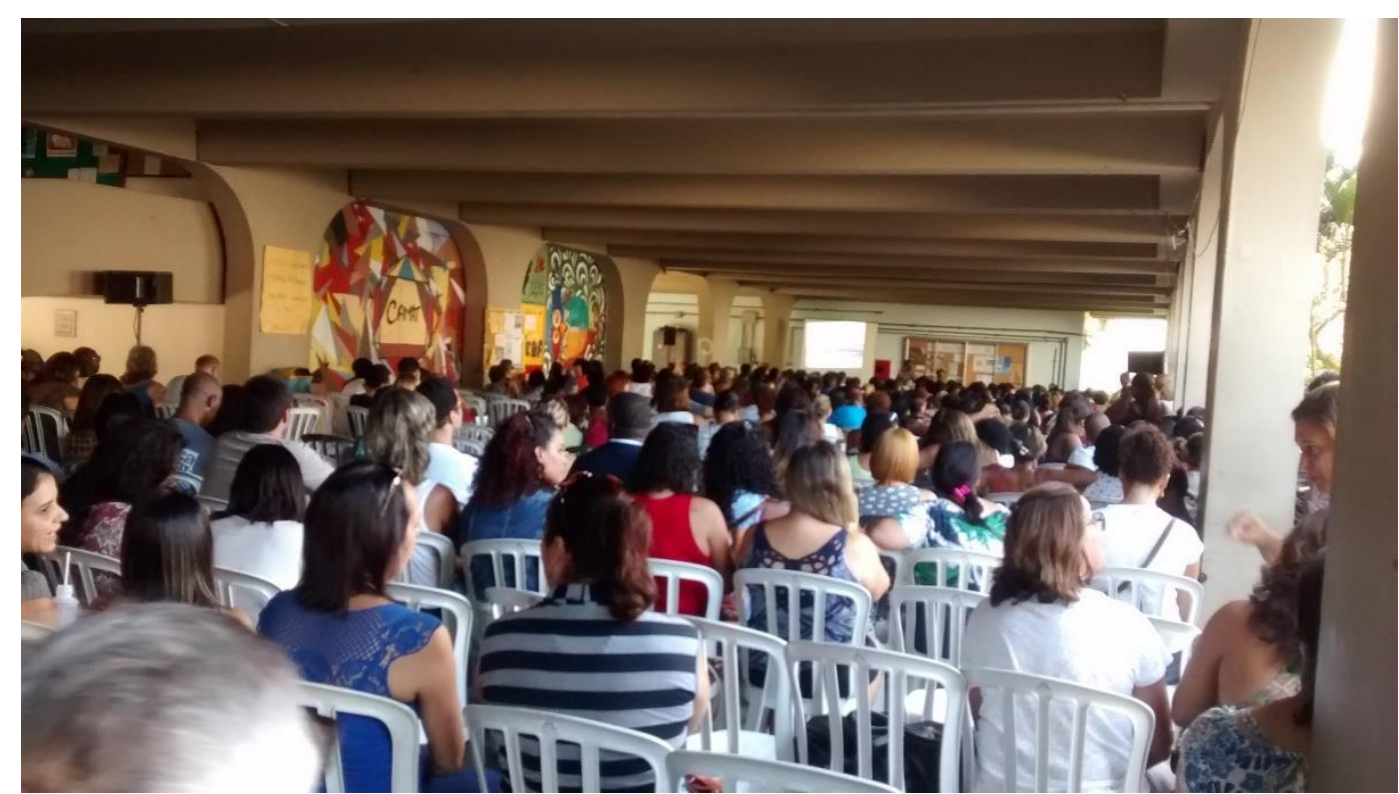

Figura 1 - Assembleia realizada no campus da FEBF em 08/04/2016

Fonte: Arquivo da pesquisa.

Assim, as inter-relações com essa instituição tem natureza material e acadêmica. Material, porque em uma "via de mão dupla" a FEBF cede ao sindicato seu espaço (são usadas as salas, auditório e pátio) com condições e recursos adequados para a realização de palestras, plenárias e conselhos (a sede do núcleo sindical é pequena). O sindicato, por sua vez, contribui com a universidade, ao divulgá-la ${ }^{45}$ aos professores do município e à população com quem eles têm contato e influência (alunos e família). Acadêmica porque a FEBF vem contribuindo com o movimento sindical na cidade ao promover palestras, cursos e eventos em conjunto com o sindicato, onde estão presentes tanto os professores da universidade quanto os professores da rede em um intercâmbio de ideias. De acordo com o site da instituição, a FEBF é:

Um importante polo de capacitação de pessoal para o setor educacional da Baixada Fluminense por estabelecer convênios de cooperação técnica com órgãos públicos e associações não governamentais nos municípios da região - abrindo espaços de aprendizagem, formação e estudo para os nossos alunos. [...]. Os docentes da Faculdade coordenam diversos projetos de pesquisa e extensão relacionados aos problemas educacionais da região. O compromisso da Faculdade é desenvolver diversas atividades visando a representar, cada vez mais, o Ensino Superior Público Estadual, em outras palavras, a presença física e acadêmica da Uerj na Baixada Fluminense. (FEBF, 2017, s/pág.).

\footnotetext{
${ }^{45}$ Grande parte da população caxiense, incluindo alguns moradores do bairro Vila São Luís, onde a FEBF está localizada, ignoram sua existência. Em pesquisa realizada junto a famílias de camadas populares e "nova classe média" de Duque de Caxias, Souza (2012) destaca que essas famílias sequer tinham a FEBF, ou qualquer outra universidade pública, como um horizonte possível para os seus filhos.
} 
Mário, como aluno do curso de pedagogia na FEBF e diretor sindical, se intitula "um estudante-militante", pois sempre aproveita o espaço das assembleias e demais plenárias para divulgar os cursos e eventos desenvolvidos pela faculdade. Para ele, essa é uma forma de resistência ao declínio da instituição, que vem sofrendo baixas de alunos pelos transtornos causados a partir da "crise" do Estado do Rio de Janeiro, colocando em risco o futuro da Uerj e mais especificamente a própria existência da Unidade de Formação de Professores da Baixada Fluminense (FEBF).

A Fundação Educacional Duque de Caxias (Feuduc), onde se formaram Rosa, Galeano e Elis, é uma instituição privada situada no bairro São Bento, $2^{\circ}$ Distrito de Duque de Caixas. Ela foi criada em 25 de setembro de 1968, visando o atendimento da demanda por formação no município.

Essa iniciativa, na época, representou um grande avanço para o município que carecia de quadros de formação superior, particularmente para o Magistério, e que se deparava com um crescimento populacional explosivo e desordenado e com as graves consequências sociais e urbanas derivadas desse fenômeno. (Braz, 2013, s/pág.).

Com baixas mensalidades e parcerias para a distribuição de bolsas de estudos, a Feuduc tem como público as camadas populares de Duque de Caxias e municípios vizinhos da Baixada Fluminense:

Seus alunos oriundos, majoritariamente, dos segmentos socioeconômicos C, D e E são homens e mulheres simples que alcançam sua ascensão social a partir da qualificada formação que recebem. São pedreiros, vigias, comerciários, donas de casa, domésticas, operários, motoristas, feirantes, vendedores e outros trabalhadores diversos e filhos desses mesmos trabalhadores que tem se transformado em respeitados professores e pesquisadores de renome nacional e internacional. (Braz, 2013, s/pág.).

Um dos enfoques da instituição é a pesquisa sobre a Baixada Fluminense e o desenvolvimento de quadros de profissionais que olhem criticamente e atuem sobre as questões da cidade:

E é esse rico diálogo entre a condição social de seus quadros e o saber acadêmico que a Instituição vincula que produz o que ela tem de mais valioso: uma poderosa leitura intelectual crítica da sociedade e da cultura brasileira como um todo e da Baixada Fluminense, em particular, construída por atores sociais que conduzem o processo de construção da sociedade através do trabalho e que, ao mesmo tempo, são os que mais sofrem as mazelas geradas pela arquitetura socioeconômica desigual do mundo em que vivem. Essa condição especial de produção do conhecimento na práxis tem se materializado nas produções acadêmicas construídas pelos alunos e professores da Feuduc em todos os seus campos de atuação e também na ação cidadã, 
através da qual, vários desses profissionais e futuros profissionais conduzem suas práticas cotidianas e sua atuação política. (Braz, 2013, s/pág.).

Nas observações de atuação sindical e relatos de Galeano e Rosa, foi possível notar o éthos incorporado na formação acadêmica realizada na Feuduc, expressa por Braz (2013, s/pág.) no trecho abaixo:

Esses homens e mulheres sabem que são devedores da Instituição, pois através da formação obtida ascenderam socialmente melhorando suas vidas e de suas famílias. Mas também sabem que foram, e que ainda são, protagonistas de sua construção e de uma identidade institucional que é muito mais do que mera formadora de quadros tecnicamente competentes em Educação. Por isso, confundem-se com ela, levandoa orgulhosamente por suas vidas através de suas experiências pessoais e suas trajetórias profissionais.

Obviamente é preciso problematizar os históricos que, como o de Braz (2013), são extraídos dos sites das instituições, pois há certa "romantização" na construção do discurso sobre a instituição. Ainda assim, neles encontramos algumas pistas corroboradas pelos relatos dos depoentes e pelas observações realizadas no decorrer da pesquisa:

Eu era do DCE da Feuduc, eu participava do movimento estudantil, como eu não consegui no ensino médio formar o grêmio estudantil, quando cheguei na faculdade, eu: "Pô, quero participar do..." Era diretório acadêmico, depois transformou em DCE, e eu, toda minha vida escolar, eu estava no movimento estudantil ali, e é claro que isso somou bastante porque era uma faculdade que tinha muita gente da categoria. Feuduc era a faculdade que pegava muitos profissionais, e o Sepe inclusive ia lá pedir ajuda a gente do DCE pra "correr escola", para falar com os professores. Então, esse é um pouco o meu histórico até chegar a participar do movimento enquanto base do sindicato. (Galeano).

Na fala de Galeano, e também na observação da presença de professores da rede em cursos e palestras organizados em conjunto com o sindicato, é possível notar que, sem dúvida, FEBF e Feuduc são instituições educacionais importantes na história de formação de professores da rede municipal de Duque de Caxias e, por conseguinte, para história da educação nesse município.

A seguir, trago cartazes exemplificando algumas formações oferecidas por estas instituições junto com o sindicato: 


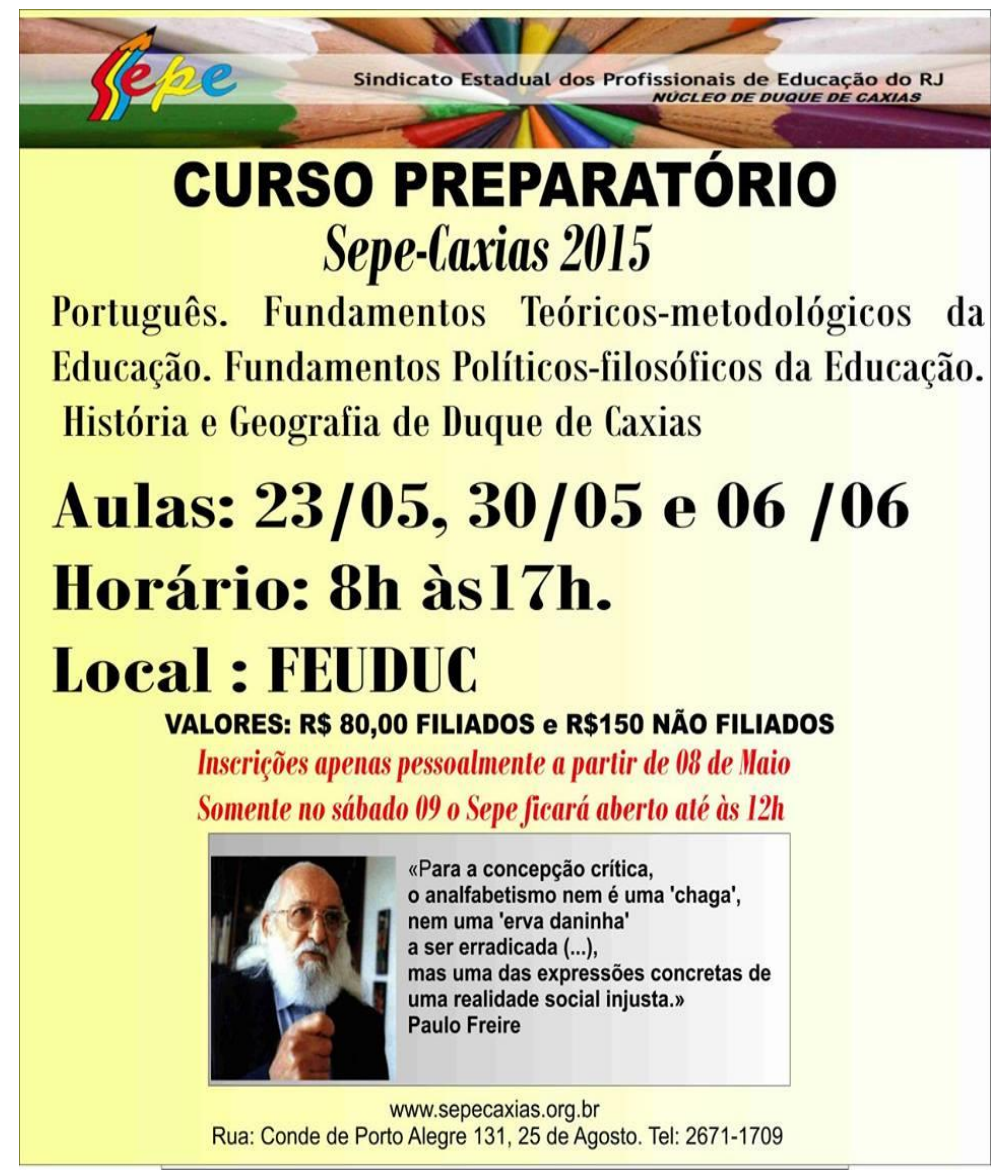

Figura 2 - Cartaz do curso preparatório para o concurso de Duque de Caxias 2015 Fonte: Sepe/Caxias, 2015.

O curso preparatório para o concurso de Duque de Caxias foi proposto pelo sindicato e realizado com o auxílio de professores da rede e professores da Feuduc que vêm desenvolvendo pesquisas sobre a história do município. Tanto o curso quanto a inclusão desse conteúdo no edital foi uma proposta da categoria docente através do seu núcleo sindical. 

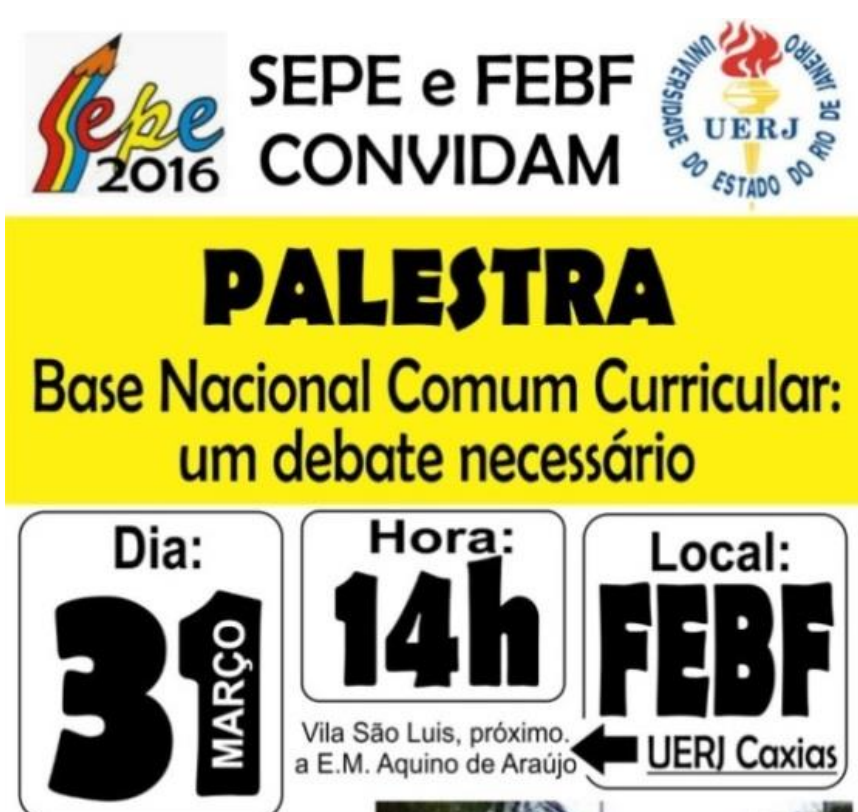

\section{Palestrante: Prof. Maria Luiza Sussekind (UNIRIO/ANPED)}

SEPENUUCLEO CAXIAS

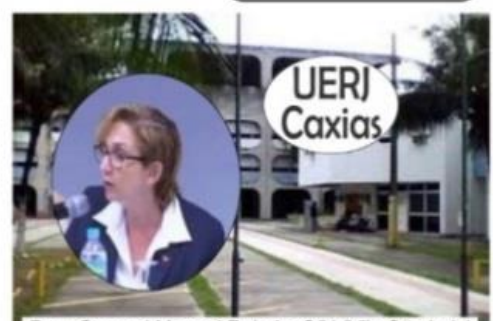

Rua: General Manuel Rabelo, SIN (Vila Săo Luiz). SINDICATO ESTADUAL DOS PROFISSIONAIS DA EDUCAÇÃO FACULDADE DE EDUCAÇÃO DA BAIXADA FLUMINENSE

Figura 3 - Cartaz da palestra "Base Nacional Comum Curricular" Fonte: Sepe/Caxias, 2016.

Mediante o contexto de discussão sobre a Base Nacional Comum Curricular, o Sepe/Caxias e a FEBF convidaram a coordenadora do GT de currículo da ANPEd, Prof ${ }^{a}$. Maria Luíza Sussekind (Unirio) para a palestra e debate sobre o tema.

Com base no cadastro de instituições e cursos de ensino superior do Ministério da Educação $(2017)^{46}$, é possível dizer que além da FEBF e da Feuduc, o município de Duque de Caxias conta hoje com mais 28 instituições de ensino superior que estão distribuídas pelos diferentes distritos, mas sobretudo no $1^{\circ}$. Em sua maioria, são instituições privadas e oferecem também cursos a distância. Das seis instituições públicas, três oferecerem cursos presenciais - IFRJ no Sarapuí ( $1^{\circ}$ Distrito), FAETEC em Imbariê ( $3^{\circ}$ Distrito), e UFRJ em Xerém ( $4^{\circ}$ Distrito) - e três são polos de educação a distância, localizados no bairro 25 de agosto e Sarapuí, ambos no $1^{\circ}$ Distrito (UFRJ, pelo Cederj, UFF e Unirio, polos da UAB).

46 Ver mais informações no site do Ministério da Educação (MEC), disponíveis em: <http://emec.mec.gov.br/emec/nova\#simples>. Acesso em: 6 jun. 2017. 


\section{3 Formação continuada}

Além da formação oferecida pelas instituições formais, qual seria o tipo de formação proporcionada pelo sindicato docente aos seus membros? Formação continuada? Formação política?

No "Dicionário: trabalho, profissão e condição", divulgado on-line pela Rede Gestrado, Pereira (2010, p. 1) ressalta, no verbete "formação continuada de professores", que historicamente no campo da formação docente "a noção de ‘formação' foi, por muito tempo, restrita ao atendimento a cursos de preparação de professores nas universidades, nas instituições de ensino superior ou de ensino médio (curso Normal)." Esse tipo de compreensão ignora a potencialidade formativa de outros espaços que não sejam de aprendizagem formal da profissão. Ainda de acordo com autor:

A ideia de que a formação de professores não termina com a conclusão de um curso preparatório, seja de nível superior ou médio, começou a ganhar força, no Brasil, a partir da segunda metade dos anos oitenta. A formação de professores passou a ser comumente dividida em duas etapas: a formação "inicial" ou "pré-serviço", de um lado, e a "continuada" ou "em serviço", de outro. (p. 1).

Pereira (2010, p. 1) salienta também a impropriedade do uso do termo formação pré-serviço "por não se adequarem à realidade de várias regiões do Brasil", afinal, como se sabe - e neste trabalho mesmo foram apontados alguns casos empíricos - existe ainda, no país:

[...] um grande contingente de pessoas que, ao ingressar em um curso ou programa de formação docente, em uma instituição de ensino superior, já atua no magistério há vários anos. A chamada "formação continuada" tornou-se, então, uma expressão bastante conhecida no Brasil, a partir dessa época. (p. 1).

Assim, a entrada informal na docência, já tratada no capítulo anterior, inviabiliza que se pense em uma educação pré-serviço, visto que é comum no Brasil, que a partir de experiências informais os sujeitos busquem posteriormente o credenciamento para o exercício do magistério, sendo chamados por Gatti e Barreto (2009) “de professores leigos", ainda presentes na realidade brasileira, especialmente nas regiões norte e nordeste.

De acordo com Pereira (2010), a visão compartimentada de "formação préserviço", estanque de "formação em serviço", sofreu várias críticas e passou a utilizar os termos "formação inicial" e "formação continuada". 
A melhor adequação do termo, contudo, não implicou necessariamente no acompanhamento da qualidade da formação oferecida. No caso da formação continuada, por exemplo, são apontados problemas como a descontinuidade dos cursos e a inadequação do seu conteúdo às necessidades dos participantes:

A "formação continuada" ou "contínua" que conhecemos configura-se, na maioria das vezes, em ações isoladas, pontuais e de caráter eventual. Portanto, trata-se de uma formação muito mais "descontínua" do que propriamente "contínua". Ainda predomina a visão da oferta de cursos de curta duração - atualização, aperfeiçoamento ou, até mesmo, "reciclagem"(sic) - ou de pós-graduação lato sensu em que os temas e os conteúdos ali tratados não necessariamente refletem as necessidades formativas dos docentes. Os professores passam a colecionar certificados - mesmo que para isso se preocupem mais em assinar as listas de presença do que em participar efetivamente desses instantes de formação - que podem significar um pequeno aumento percentual em seus já baixíssimos salários, mas que, geralmente, não trazem muitos ganhos para a melhoria de sua prática de ensino na sala de aula. (PEREIRA, 2010, p. 1-2).

A ideia de desenvolvimento profissional surge na literatura sobre o professor em contraponto a este quadro de formação muito mais descontínua que contínua, “como uma concepção de formação não dissociada da própria realização do trabalho docente." (Pereira, 2010, p. 2).

Nessa linha, o autor ressalta que não se pode discutir a formação continuada de forma dissociada das "condições adequadas para a realização do trabalho docente", o que implicaria em:

[...] salários dignos, maior autonomia profissional, dedicação exclusiva a uma única escola, pelo menos um terço da jornada de trabalho para planejamento, reflexão e sistematização da prática, estudos individuais e coletivos, salas de aula com um número reduzido de alunos. (p. 2).

Para ele, se garantidas essas condições de realização do trabalho docente, a escola se torna um "locus privilegiado para o desenvolvimento profissional dos docentes. [...] A participação dos sujeitos nesse processo de construção é considerada, por si só, algo extremante formativo.” (p. 2).

Concordando com essa visão, Alvarado-Prada et al. (2010, p. 371) ressaltam:

A instituição escolar é o espaço principal onde acontecem e precisam acontecer os projetos e atividades de formação de professores. Entretanto, para isso são necessárias condições que os viabilizem como, por exemplo, a organização da gestão institucional na qual seja previsto o tempo e diversos recursos para sua realização.

No entanto, a não garantia dessas condições adequadas para a realização do trabalho docente tem efeito contrário a essa ideia, pois "a precarização das condições, a intensificação do trabalho e o maior controle sobre os docentes levam 
à deformação gradativa desses profissionais a partir do momento que eles se inserem nas redes de ensino." (PEREIRA, 2010, p. 3).

Há muito tempo, pesquisas no campo do trabalho docente têm apontado que é muito mais comum encontrarmos o tipo de condições inadequadas ao ensino que as condições ideais apresentadas por Alvarado-Prada et. Al. (2010), exceto em escolas de prestígio que em geral atendem apenas os membros das elites sociais, culturais e econômicas. Nas escolas "comuns", públicas ou privadas, onde a grande massa de estudantes é atendida, as condições de trabalho do professor passam ao longe do que seria adequado ao seu desenvolvimento profissional. (Andrade, 2006; Lelis, 2012).

No Plano Municipal de Educação de Duque de Caxias (lei nº 2.713/2015), na seção 15.4 sobre "Formação e valorização dos profissionais da educação, formação continuada e em serviço", são descritas as condições de precariedade do exercício do trabalho docente que dificultam o processo de formação:

Em Duque de Caxias, evidenciam-se alguns aspectos nas condições de trabalho, que exemplificamos como principais, pois interferem diretamente no desempenho dos profissionais: precariedade nas condições físicas das escolas; número excessivo de estudantes na mesma sala de aula; sobrecarga de trabalho para compensar a baixa remuneração salarial. (DUQUE DE CAXIAS, 2015, p. 149).

Nessas circunstâncias de baixos salários, falta de autonomia profissional, dupla jornada de trabalho, ausência da garantia de horário para o planejamento, reflexão e sistematização da prática dentro da jornada de trabalho, salas de aula lotadas com número de alunos acima do ideal, a participação sindical pode ser o único espaço encontrado pelo professor de estímulo ao seu desenvolvimento profissional. Onde ele encontra amparo para a busca de reversão desse cenário e melhoria das suas condições de trabalho. Afinal,

A escola não é a única responsável por esta formação, embora seja uma instituição educativa e/ou de formação de professores. O espaço escolar depende de relações com outras instâncias, como o próprio Estado em seus diferentes níveis, a família e todas as organizações instituídas socioculturalmente para que ela se desenvolva. (Alvarado-Prada et al., 2010, p. 371).

Em um contexto cujas condições adequadas para o exercício profissional não estão dadas, aprender a resistir à precariedade e a buscar saídas coletivas para a melhoria da educação e da própria carreira é significativo para o desempenho da função docente. Nesse sentido, ressalto a importância do espaço sindical como espaço formativo para além da escola e das instituições formais de habilitação 
inicial ao magistério. Assim, é possível entender a militância como uma espécie de "formação continuada" para o professor, tendo em vista seu contexto de atuação.

\section{4 Formação no espaço sindical}

Kênia Miranda (2011) analisa as formulações pedagógicas de três sindicatos que compõem a diversidade do movimento sindical docente da educação básica no Estado do Rio de Janeiro, a saber, o Sindicato dos Professores do Município do Rio de Janeiro e Região (Sinpro/Rio); a união dos Professores Públicos do Rio de Janeiro (Uppes) e o Sindicato Estadual dos Profissionais de Educação do Estado do Rio de Janeiro (Sepe/RJ). Após cruzar documentos e entrevistas com os dirigentes sindicais, a autora chega à conclusão de que "o SEPE é a entidade em que encontramos o debate pedagógico mais desenvolvido, até mesmo na forma de resoluções congressuais.” (p. 120).

Ao longo das observações realizadas junto ao núcleo Sepe/Caxias identifiquei dois tipos de formação. Aquela que se dá no dia a dia entre os pares e aquela que é previamente organizada em função de um objetivo.

A primeira, que estou chamando de "formação político-sindical" se dá no cotidiano do movimento sindical, pela troca entre pares ao longo de reuniões, conselhos, assembleias, atos e toda organização sindical.

Nesse sentido, a fala de Galeano ressalta a importância formativa da participação nas atividades promovidas pelo sindicato, inclusive ações usuais do movimento de greve, como a "corrida às escolas", na qual membros do sindicato, diretores e professores vão até as escolas convencer os colegas a aderirem à greve:

Esse nosso movimento mais geral da greve, de correr escola, de representante, de... Essa estrutura, pra mim, ela é extremamente importante no processo de formação, ninguém passa por uma greve e que se envolva, sai da mesma forma. Não estou falando aquele que fica lá na periferia, lá na escola, mandou parar, o cara parou, mas quem veio pra assembleia, fala, que olha, que ouve de um, que sente emoção, se emociona, que xinga aquele que tá falando, essas pessoas, elas de alguma forma sofrem algum tipo de mudança. [...] Como é que você vai ver isso? As pessoas vindo para a direção do SEPE, compondo o conselho de representantes... Então, você vê que as pessoas vão tendo um nível de engajamento maior. A gente de Caxias, aqui, sempre teve, além de permanecer uma galera boa antiga, a gente sempre tem um contingente de pessoas novas na direção... (Galeano). 
$\mathrm{Na}$ fala do professor, esse tipo de formação retroalimentaria o movimento sindical, fazendo com que seus quadros sejam sempre renovados e solidificados. De modo que a continuidade do movimento sindical em Duque de Caxias e a renovação das suas lideranças é mostra do potencial formativo do sindicalismo nessa rede.

O sindicato de Caxias, eu acho que ele tem um diferencial mesmo, que é esse diferencial de formação, de chamar para perto, de estar junto, de fazer as pessoas entenderem que tem um grupo eleito, mas que não é só o grupo eleito que dá conta, a gente está junto... Por conta disso, a gente acaba até se envolvendo um pouco mais em algumas coisas, a gente vai tendo mais atuação (Cecília).

Essa formação tem características político-ideológicas, pois está ligada ao conhecimento dos direitos, participação e interação com a sociedade, conscientização enquanto categoria docente, e luta de classes.

Quando eu digo que o movimento sindical foi que me deu, assim, uma formação, é porque me forçava à leitura, eu tinha que ler. Uma sindicalista que defende os interesses da classe trabalhadora, que faz greve, ela tem que saber a origem desses movimentos. Aí, você vai estudar Revolução Russa, Revolução Francesa, descobre que houve a comuna de Paris, que quase ninguém fala dela, que foi um patrimônio pequeno, minúsculo em tempos, mas grandiosíssimo. Enfim, vai lendo, descobre que existe educadores russos, comunistas. Era isso, eu procurava isso. (Olga).

Na linha do que coloca Olga, Clarice ressalta o quanto a militância sindical a instigou a estudar, buscar se aprimorar para exercer melhor a militância. O conhecimento adquirido contribuiu para o seu fazer na escola.

O sindicato me obrigou muito a estudar. Fui fazer o mestrado, por causa do sindicato. [...] Então, foi isso, ter que ir para a mesa de negociação... Ter que saber falar, me obrigou a estudar muito. $\mathrm{O}$ que eu acho que também se refletiu... Me ajudou no trabalho como orientadora na escola, o que me ajudou também no trabalho como professora... É óbvio que eu não sou a mesma pessoa. Assim, eu acho que a experiência do sindicato é uma experiência necessária... Algum nível de participação no sindicato. (Clarice).

Embora seja uma formação voltada à ação coletiva, esse tipo de formação é de difícil mensuração, visto que ela age sobre os conhecimentos e experiências pessoais de cada participante do sindicato, extravasando a esfera coorporativa. Portanto, sua aprendizagem varia de acordo com suas disposições anteriores e intensidade de atuação no movimento. A fala de Cecília, relatando sua experiência de aprendizagem no núcleo do Sepe/Caxias, exemplifica a dimensão desse tipo formação:

Traz para o exercício da profissão, para o exercício dos seus papéis familiares, o seu exercício na igreja, o seu exercício social, traz para sua vida. Não tem como, não fica 
só no âmbito profissional, não! Você leva para sua vida... Tanto que tem pessoas que depois que começam a ficar atuante no sindicato, elas começam a ficar mais questionadoras com o marido, no espaço familiar: "Por que que eu estou sofrendo essa opressão? Por que que meu marido age assim e eu tenho que ficar calada?" Eu acho que é isso, ele rompe a barreira da profissão para vida... Acaba que você mexe com a sua vida como um todo, eu acho... Eu acho que eu sou outra pessoa. (Cecília).

Assim, como afirma Gohn (2012a, p. 56), "nos movimentos sociais a educação é autoconstruída no processo e o educativo surge de diferentes fontes de saber", na ação sindical, na troca de saberes entre pares, no estímulo ao estudo e à criticidade, etc.

O segundo tipo de formação observada é chamada aqui de "formação político-pedagógica". Ela segue um objetivo específico, quase sempre pedagógico ou funcional. Visa atender uma demanda imposta ao sindicato no contexto das lutas travadas pela melhoria das condições de exercício da docência.

Para sua execução, recorre-se ao intercâmbio entre instituições, buscando a ajuda de especialistas acadêmicos, trazendo assim, certa carga hierárquica à formação do ponto de vista do "saber científico". Por outro lado, aproveita-se também a experiência profissional, acadêmica e de diferentes militâncias dos próprios professores da rede municipal em articulação com seus outros vínculos institucionais.

Trazemos um fragmento do diário de campo a exemplo dessa articulação entre a academia e a prática docente, realizada pelo Sepe, empenhado em atender uma demanda da categoria, no caso, a implementação da lei no 10.639/03:

O Sepe vem promovendo por intermédio de seus núcleos, discussão sobre a lei 10.639/03, para fazer um balanço sobre esses 14 anos de aplicação. Nove núcleos encamparam esse debate, um deles foi o de Duque de Caxias. O seminário foi organizado pelas diretoras Dandara e Rosa, cujas falas abriram e fecharam o evento. Na mesa de discussão, estavam o professor Luiz Fernandes da UFFRJ, o professor Júlio e a professora Marize, da rede estadual e municipal. O debate foi intenso, regado de muitas questões e relatos de experiências. A fala do professor Luiz Fernandes, mais acadêmica, apresentava uma série de problemas no interior da ciência eurocêntrica que, segundo ele, "colonizava" o conhecimento sobre a África. O professor Júlio, orientando do professor Luiz Fernandes, trouxe a experiência de anos trabalhando com o projeto "Africanidades" no interior das escolas a que pertence. Em sua fala, muitas histórias de resistências por parte de alunos e professores. Na fala da professora Marize predominou a questão da invisibilidade e o apagamento das populações indígenas. (Diário de campo, 19/05/2017).

No Sepe/Caxias, a formação político-pedagógica não obedece a uma periodicidade sistemática, mas é promovida em função de uma necessidade das escolas e dos profissionais da educação em seu contexto de trabalho. Abaixo, trago 
alguns exemplos de atividades dessa natureza, observados ao longo de julho de 2015 a junho de 2017:

$\checkmark$ Atividade em conjunto com a FEBF e outras universidades:

- Palestra com a Prof ${ }^{a}$. Gilcelene Barão (FEBF) - gestão democrática;

- Palestra com a Prof ${ }^{a}$. Icléia Melo (FEBF) - gestão democrática;

- Exibição e debate sobre o documentário "O menino 23"47 - discriminação racial;

- Palestra com o Prof. Rodrigo Lamosa (Unirio) - estudos de Gramsci.

\section{Atividades em conjunto com o Museu Vivo de São Bento}

- Curso preparatório para o concurso de Caxias;

- Palestra com a Prof ${ }^{a}$. Marlucia Santos de Souza - Violência na Baixada Fluminense;

- Palestra com Roberto Ponciano Gomes de Souza Júnior e Marcos Vinícius Carvalho - "O que é ideologia?" -

\section{$\checkmark$ Atividades em conjunto com os movimentos sociais da cidade}

- Lançamento do livro da Prof". Luciene Medeiros "Em briga de marido e mulher o Estado deve meter a colher" - movimento feminista;

- Aula inaugural do pré-vestibular comunitário - movimento estudantil;

- Debate com os candidatos a prefeito - união de diversos movimentos sociais existentes na cidade;

- Lançamento do livro "Duque de Caxias, seu território e sua gente" - (Fórum de Oposição ao Shopping - Foras);

- Curso de direito à cidade - Foras.

\section{$\checkmark$ Atividades dinamizadas pelo sindicato}

- Formação para as novas diretoras eleitas e construção da gestão democrática (palestra e debate sobre a prática das direções eleitas);

- Reunião com os especialistas, orientadores pedagógicos e educacionais (resgate das pautas históricas dessas categorias junto ao sindicato);

- Plenária de construção da minuta da Educação de Jovens e Adultos; Educação no Campo e Educação Especial;

\footnotetext{
${ }^{47}$ Essa atividade foi organizada pelos Centros Acadêmicos Henfil (FEBF) e Sueli do Nascimento (Uerj) e pelos coletivos "Filhas de Dandara" e 111 e contou com a colaboração e participação do Sepe/Caxias.
} 
- Debate sobre a educação infantil (1/3 de planejamento, relações entre professores e estimuladores-materno infantil);

- Seminário sobre relações-étnico raciais.

Os processos formativos desenvolvidos no núcleo sindical são elaborados pelos próprios profissionais da educação que fazem parte desse movimento. Nesse caminho, eles também lançam mão da articulação com outras instituições, como universidades e movimentos sociais a fim de agregar conhecimentos à luta sindical docente, o que enriquece a formação pela amplitude de espaços: sindicato, universidade, museu; e pautas abordadas: gestão democrática, território, eleições, violência contra a mulher, entre outras.

Por outro lado, a descontinuidade das ações, a falta de aprofundamento em determinados temas e a rotatividade dos participantes são desafios presentes no processo de consolidação da formação no espaço sindical, tais como os problemas apresentados por Pereira (2010) sobre a formação continuada. Ainda assim, tendo em vista a finalidade primária da instituição sindical, cujas atribuições são econômico-corporativas, o quantitativo de ações formativas observadas demonstra claramente uma preocupação desse núcleo sindical com a formação do professor. Isso apareceu não apenas nas observações para esta pesquisa, mas também no relato de alguns diretores sindicais, como o de Galeano:

A formação é um tema bastante complexo, a gente já tentou de tudo, toda quarta, a gente organizou uma atividade para falar da questão do sindicato, pensar sociedade, conjuntura. A gente já fez vários debates específicos que estavam na ordem do dia, sobre avaliação, sobre currículo e tal, a gente promoveu encontros, disso a gente tem que se orgulhar... É... só que não é uma coisa sistemática e perene. E não sei, se a gente..., o Sepe também e aí, falando não como o Sepe/Caxias, mas o Sepe como um todo, a gente fez um convênio com a UFF de formação, só que assim, é uma coisa muito restrita... ela é de pós então o universo, o público era bastante restrito, mas, por exemplo, todo debate em torno de gestão democrática, sobre eleição, conselho escolar, a gente trabalha muito com a Uerj, algumas professoras estão sempre aqui, a Alzira, a Gil, a Icléia,. Elas estão sempre com a gente aqui, dando apoio, suporte, a gente sempre quando chama, elas tão juntas... (Galeano).

A despeito da complexidade da tarefa de organizar formações sistemáticas aos filiados, esse diretor sindical afirma com orgulho que alguns debates têm sido realizados com profundidade em Duque de Caxias. Ele cita a questão da gestão democrática que, como foi observado, vem sendo constantemente abordada por esse núcleo sindical. 
Sobre o curso de pós-graduação, mencionado pelo diretor, este resultou de uma parceria entre o Sepe/RJ e a UFF, que englobava diferentes ações formativas com apoio de professores de diversas universidades.

Dentre outros trabalhos desenvolvidos conjuntamente, esta parceria criou o curso de pós-graduação em Educação Brasileira e Movimentos Sindicais em que, além das exigências de praxe, havia uma condição básica para participar: ser militante - na escola, nas regionais ou nos núcleos do sindicato - como dirigente sindical. (Cadernos do SEPE, 1998 apud Xavier \& Salomão, 2010, p. 4).

Analisando três edições do "Cadernos do Sepe", publicação na qual eram divulgados os trabalhos monográficos de conclusão do curso, Xavier e Salomão (2010, p. 7) apontam que:

[...] o que se pode perceber retrospectivamente a partir da análise do material selecionado é o encontro entre o movimento sindical, o desejo de mudança política e a mobilização dos espaços de reflexão acadêmica, tendo em vista a formação política dos militantes fundamentada em estudos e pesquisas. Tais espaços e perspectivas foram integrados de modo estratégico na parceria que resultou na organização do curso de pós-graduação e na publicação dos Cadernos do Sepe Série Acadêmica.

Frida aponta o desafio que o quadro atual de retirada de direitos e intensificação da precarização da docência traz ao sindicato enquanto instância formativa, tanto em termos de organização, quanto de motivação do corpo docente:

Sempre tem gente da categoria que fala: "Eu quero saber de formação?! A gente está sem salário, eu quero saber do salário!" [...] Nesse momento, você fica o tempo todo tendo que correr atrás dos ataques do governo e a gente não está conseguindo fazer isso [oferecer discussões sobre a concepção pedagógica da rede] porque já fizemos muito isso em outras épocas... Hoje, eu acho, que a gente tem essa debilidade porque a gente está o tempo todo tendo que apagar incêndio. (Frida).

A despeito das dificuldades apontadas, para Frida, o caminho é a união com os demais movimentos e instituições educativas da cidade. Formar alianças, assim como foi realizada em âmbito mais amplo entre o Sepe e a UFF, na busca por afirmar o caráter formativo da entidade: "[...] acho que a gente tem que tentar trabalhar nessa coisa... de estar fazendo formação política, de está trazendo a academia. A gente tem que brigar muito..."

O quadro a seguir traz a síntese das características dos dois tipos de formação apreendidas nas observações das ações coletivas no núcleo sindical Sepe/Caxias: 
Formação político-sindical

- Provém da troca entre pares

- Sem hierarquizações

- De difícil mensuração

- Conteúdo político e ideológico

- Formação para ação coletiva

Quadro 3 - Síntese da formação "político-sindical" e "político-pedagógica"

Fonte: Elaboração própria.

Para aprofundar mais a questão da formação no espaço sindical, no capítulo seguinte abordo as diferentes trajetórias de participação no Sepe/Caxias, o ingresso no movimento, o engajamento dos militantes e a construção coletiva da história do sindicalismo docente em Duque de Caxias. 


\section{4 \\ Trajetórias sindicais}

Uma história de vida não é feita para ser arquivada ou guardada numa gaveta como coisa, mas existe para transformar a cidade onde ela floresceu.

Ecléa Bosi

Neste capítulo, analiso os relatos referentes à trajetória sindical percorrida pelos diferentes professores militantes que participaram da pesquisa.

Na perspectiva de Bourdieu (2013, p. 50), em que "um grupo social tem tanto mais oportunidades de existir e subsistir de maneira durável quanto mais os agentes que se agrupam para constituí-lo já estejam mais próximos no espaço social”, a filiação, frequência e níveis de participação no sindicato devem ser postos em relação com a participação em outros espaços sociais, por isso, foi imprescindível buscar nas trajetórias os outros campos onde os professores sindicalizados atuaram antes do ingresso na militância sindical, bem como os novos campos sociais que se apresentaram a partir desse engajamento.

A chegada ao sindicato e os primeiros passos em direção a uma militância política, são abordados na primeira parte do capítulo, em que ressalto a influência da igreja católica mediante a difusão da teologia da libertação, e o envolvimento com o Partido dos Trabalhadores (PT), propiciado pela esfera política de redemocratização do país no fim dos anos 1970 e início dos anos 1990, quando a maior parte dos entrevistados teve os primeiros contatos com o sindicalismo docente.

Na segunda seção, trago a história do Sepe/Caxias contada pela voz de seus participantes em assembleias, atos, conselhos e também nas entrevistas que realizei. São falas que relembram a ocasião da fundação; a ampliação da representação sindical aos demais profissionais da educação; greves históricas, avanços e retrocessos ao longo das lutas travadas em datas-bases.

$\mathrm{Na}$ última seção do capítulo, trato do engajamento sindical e dos diferentes níveis de atuação vividos pelos professores ao longo da trajetória de participação no Sepe/Caxias, ressaltando também as respostas obtidas nos questionários aplicados na data-base de 2016 e a influência da participação sindical nas relações estabelecidas na escola. 
Assim, através da voz dos seus participantes e das observações de seus repertórios de ação, registro neste capítulo um pouco do sindicalismo construído em Duque de Caixas por docentes e demais profissionais da educação.

\section{1}

\section{A chegada ao sindicato}

Nesta seção, debruço-me sobre as narrativas dos entrevistados a respeito de sua entrada no movimento sindical, ressaltando os diferentes e semelhantes caminhos que levaram esses professores ao sindicalismo. Sem "esquecer que o que permite com frequência o êxito das mobilizações coletivas e sua inscrição na duração é precisamente a existência de experiências sociais compartilhadas por grupos de indivíduos com propriedades análogas, senão similares." (Sawicki \& Siméant, 2011, p. 217).

Entre os espaços frequentados antes do envolvimento sindical, destacam-se a igreja, a universidade e o partido político, sendo este último também apresentado aos professores via militância sindical, pelo convívio com membros atuantes em ambos os campos.

De acordo com os relatos de Nise, Rosa, Galeano, Elis, Clarice, Olga e Zilda, a igreja católica progressista foi significativa nos primeiros passos em direção à organização política. Tendo em vista que esses narradores são oriundos de famílias humildes, não politizadas (excetuando Elis, que tinha pais bastante atuantes em sua comunidade), e tiveram sua primeira experiência participativa na sociedade através do ingresso nos chamados "grupos jovens" da Igreja Católica entre o fim dos anos 1970 e início dos anos 1990.

Eu acho que veio [a militância] muito mais com a igreja porque eu participava também de grupo jovem, eu costumo falar que a nossa juventude, eu, minha irmã, meu cunhado e vários outros colegas, a nossa juventude era assim: era igreja e associação de moradores, nós devíamos ser chamados de muitos chatos. É porque era política o tempo inteiro, a gente respirava política. A gente comia política, respirava política e domingo aquele sol, aquele domingo ensolarado, 40 graus, o nosso programa não era praia, não era cinema, teatro não tinha dinheiro - até a gente gostava - era igreja, eram aqueles encontros do grupo jovem para falar de quê? De fé e libertação e fé e libertação era aqui na Terra, com vida melhor, condições dignas. (Elis).

Nise, Elis, Clarice e Galeano - todos de uma mesma faixa etária - parecem ter vivido o auge da atuação das comunidades eclesiais de base, quando a igreja 
praticava a teologia da libertação, pela qual difundia valores que impulsionavam a "ação sobre o mundo" e, portanto, a participação em diversos movimentos sociais e políticos.

O desdobramento dessa prática resulta no fato de que alguns líderes das CEBs optam por atuar nos conselhos municipais, nas associações de bairros e no campo político, demonstrando que o trabalho pastoral estava atingindo seus objetivos: a organização de seu público leigo. [...]. Consequentemente, a atuação das CEBs espraia-se para o movimento social como um todo, influenciando o próprio movimento dos professores da Baixada. (SILVA, 2012, p. 65).

Tal compreensão de atuação no mundo viria mais tarde a ser um fator influenciador da militância sindical. Inclusive esse tipo de militância é apresentado à Nise, Clarice e Elis, antes mesmo da entrada delas no magistério, pelas relações estabelecidas a partir das CEBs:

Quando o movimento das comunidades eclesiais de base era muito forte, o movimento era muito forte na Baixada, Caxias era muito organizado nesse sentido. Nesse período da Pastoral Operária, eu já estava fazendo o curso Normal, então lá na Pastoral Operária eles me aproveitavam muito para escrever, porque eu tinha uma facilidade de escrever, aí eles me botavam para eu fazer os panfletos. Eu ia muito ao Sindipetro, o sindicato dos petroleiros em Caxias, para escrever panfletos para eles, organização de greve. [...] Aí, aos poucos, eu fui participar de piquete, de movimento, assim, de porta de fábrica, de processo de formação, era muito incipiente, mas existia... De assistir vídeos, com os trabalhadores do Sindipetro... Na época, eu não entendia muita coisa, mas era legal estar junto, estar no meio, era legal... (Clarice).

Com a ida para a faculdade depois, eu comecei a conhecer a questão, me envolver na questão da educação, aí, juntando a questão do PT, juntando a questão do grupo da igreja, movimento social em Caxias, eu conheci o pessoal do Cepe - que não era Sepe naquele momento - a gente se conhecia na militância e aí o pessoal do MUB também, que é o Movimento União de Bairro, que era a Federação das Associações de Moradores. [...] Aí, logo depois... Quando eu fiz o concurso e passei, me tornei professora da rede, demorou um ano e pouco, já...Vamos pra direção, aí já estava no Sepe, já virou Sepe. (Nise).

Analisando a trajetória de vida de nove professores ligados ao Sepe na Baixada Fluminense, Silva (2012) aponta a importância das comunidades eclesiais de base para a formação política desses sujeitos, ressaltando que o movimento teve origem histórica no Concílio Vaticano II, realizado em 1968.

Segundo ela, a adoção de um conjunto de medidas de modernização objetivando a aproximação com seus fiéis, traz "um novo olhar para a Igreja na América Latina e consolida sua opção pelos pobres e o florescimento da própria Teologia da Libertação encontra na Baixada um solo fértil para o seu crescimento." (Silva, 2012, p. 62). 
Assim, nos anos 1980-1990, a "influência das comunidades eclesiais de base", citada por Nise em seu relato, atingiu fortemente as igrejas da Baixada Fluminense, através de Dom Adriano Hipólito e Dom Mauro Morelli, bispos diocesanos de Nova Iguaçu e Duque de Caxias, fundamentais nesse movimento de “abertura das portas da Igreja da Baixada para o movimento popular" (Silva, 2012). Nesse entrelaçamento da igreja progressista com o movimento popular, Rosa foi introduzida ao movimento negro, onde até hoje milita de forma concomitante com o movimento sindical docente:

Tem uma referência que é da década de 80 , que foram os movimentos de base da igreja católica com pastoral do negro, pastoral da terra, então, acho que o movimento sindical e o movimento negro a partir desse envolvimento com a igreja católica é que abre para outros espaços de militância. Aí, sim, que vem uma militância mais orgânica, mas tudo a partir do envolvimento sindical. E mais na vida adulta mesmo, que nessa época de estudante não militei em nenhum movimento estudantil. (Rosa).

Para Elis e Galeano a teologia da libertação os impulsionou à filiação ao PT que, na época, era a expressão política do que era proposto nas CEBs:

Primeiro veio a comunidade de base que eu vim desde a minha infância, a minha mãe me empurrando, essa coisa toda... Aí, depois, veio o PT porque naquela época, muito interessante a história do PT... Porque agora se esgarçou... Mas a igreja progressista mais o movimento popular e o movimento sindical progressista vão se unir, se juntar. E dessas três ferramentas aí nasce o PT, então o PT, ele é um produto desse conjunto de fatores e eu, como estava na teologia da libertação, então a gente, essa galera se aproximou do PT. [...] Esse movimento na teologia da libertação que me levou para o PT. (Galeano).

Eu sou católica e nós somos de uma época da teologia da libertação que, assim, não existia fé sem ação, então ninguém mandava você ir para o partido, que na época era PT, mas, assim, todas as ideias convergiam, o sonho, o idealismo era da teologia da libertação, era o que o PT pregava. [...] Era muita coisa boa, era fé, libertação, ação, trabalho, então era assim, aquela coisa de ir para a rua, de conscientizar, de mudar. (Elis).

A experiência vivida nessa aproximação entre igreja, partido político e movimentos sociais, aparece sintetizada na fala de Galeano:

Porque tanto na igreja, como no partido, tinha essa perspectiva, não adianta você estar aqui para ficar aqui dentro, você está aqui para atuar no mundo, você está aí para interferir... Tem que ser o sal na Terra. Então, isso tudo fez a gente ter esse olhar: "ó, você tem que estar nos movimentos sociais", porque é um pouco uma perspectiva leninista também. E eu nem dominava muito essas terminologias, mas essa coisa da importância do filiado, do militante fazer ativismo, que, senão, não tem sentido, né, você querer transformar a realidade, se você não vai disputar as pessoas... As concepções... 
Nas trajetórias de Zilda e Francisca o envolvimento político partidário ocorreu em decorrência dos limites de atuação da militância sindical:

Porque eu estava no sindicato por reconhecer no sindicato a sua importância na luta dos trabalhadores, mas a minha posição maior não era só essa luta, era transformar a sociedade. E, nesse sentido, o sindicato tinha seus limites. Obviamente, já estou filiada ao Partido dos Trabalhadores, mas nunca tive uma militância orgânica no PT. Mas, eu me aproximo de uma tendência do PT... A partir da educação, de militante da educação, a partir de uma reflexão sobre o sindicato. Eu me aproximo de uma tendência dentro do PT, que é a força socialista, e a partir daí que eu vou para o sindicato Sepe/Rio porque, até então, a minha tendência era me afastar do sindicato, mesmo porque... Toda crise que você tem, ser direção sindical, trabalhar, cuidar e... Se você não está num bojo de uma discussão política mais ampla, é... Pelo menos, para mim, isso era insuficiente, ficar na direção do sindicato sem uma direção política mais ampla. (Zilda).

À medida que eu fui para rua, que eu fui pro sindicato, que eu comecei a participar de congressos, que eu comecei a ler mais, a estudar mais, por isso, eu digo, que eu comparo a um curso superior, você lê muito, muito e várias posições, assim, não tinha como, eu tinha que ter um lado, essa história de cima do muro não existe, você tá lá ou você está cá, na época era o PT, então eu entrei pro PT em Caxias. (Francisca).

Olga, Nise, Clarice e Mário mencionam a atuação de militantes partidários na FEBF, tanto entre os alunos como entre o corpo docente, interligando as relações entre a universidade, o partido político e o sindicato de professores.

E aí, a gente muito engajada nessa tentativa de formar o núcleo do PT na FEBF, só que ao invés do núcleo do PT, eu acabei ficando no centro acadêmico desde o primeiro ano, até o quarto ano. Fui de diversas diretorias do centro acadêmico e foi um período muito bacana, de muito aprendizado. (Clarice).

O sindicato pra mim foi extremamente importante porque aliou-se à minha formação acadêmica; por estar dentro de uma faculdade pública, uma faculdade de educação, eu tive a oportunidade de conviver com professores extremamente militantes e que essa minha aproximação, essa minha participação na direção do sindicato, me permitiu ter um diálogo muito mais próximo e me permitiu compreender o que é luta de classe, entender o papel do sindicato como uma ferramenta para combater essa desigualdade social que se dá pela opressão do capital nas populações trabalhadoras, no povo trabalhador, que é o povo que sofre realmente na nossa sociedade. (Mário).

Olga, uma das fundadoras do núcleo sindical do Sepe em Duque de Caxias, mencionada no relato de Clarice, iniciou sua carreira política junto com a fundação do PT em Duque de Caxias, sendo posteriormente vereadora do município do Rio por essa legenda e candidata a diversos cargos eletivos pelo seu atual partido, o PSTU.

Eu briguei aqui contra o prefeito, briguei aqui com o Estado, fundando o PT aqui. Eu me lembro que nos finais de semana, a gente ia batendo palma em todas as casas, 
para perguntar: "Por favor, você não quer se filiar? A gente precisa da sua filiação para oficializar o Partido dos Trabalhadores e tal", as pessoas tinham medo, ficavam... Mas, você pegava outras pessoas que: "Não, claro, tem que ter sim! Chega de ditadura e de não sei o quê e tal". Era aqui na Baixada, Centenário ${ }^{48}$, basicamente foi Centenário que a gente fez. (Olga).

Quando chegou ao sindicato, Frida já tinha uma participação ativa no movimento estudantil e no partido político; ela atribui sua aproximação com a política às inquietações sentidas diante das desigualdades sociais:

Quando eu estudava no 18 de dezembro ${ }^{49}$, que eu fazia o supletivo lá, eu comecei a participar com o pessoal, que era do movimento, do $M R 8^{50}$, e aí foi quando eu comecei a participar até das associações de moradores, foi antes do movimento estudantil; depois continuei também participando do movimento estudantil. Mas, eu sempre tive esse negócio, eu sempre fiquei muito mal de ver mendigo na rua... De ver as injustiças... Isso me tocava muito, eu sempre tive essa coisa. Aí, acabei entrando para o Partido Comunista Brasileiro, saí em 1985, quando foi legalizado por discordar de uma visão muito reformista. Aí, fui para o PT, fiquei 19 anos no PT, saí do PT, quando o Lula ganhou, com a reforma da previdência. (Frida).

De uma geração mais jovem, Tarsila, filha de sindicalista, também participou do movimento estudantil na faculdade, fazendo com que, aos seus olhos, a filiação ao sindicato dos professores fosse um caminho a ser seguido "automaticamente", pois alguns repertórios de ações eram os mesmos:

Até na faculdade, eu era do centro acadêmico. Então, já vinha... Eu já era do comando de greve na faculdade. Então, quando eu vim para cá, o comando de greve, para mim, greve eu já sabia o que era. Não tinha o questionamento: "Pode, não pode?". Aquilo ali já fazia parte do meu cotidiano. Então, quando eu entrei, meio que já era a mesma coisa [risos]. Para mim, eu já fazia na faculdade, então... Tinha o comando de greve que era organizar, mobilizar, então, eu já fazia isso lá. [...] Então, pra mim, já foi automático. Não teve problema. (Tarsila).

Tarsila também trabalhou voluntariamente junto a pré-vestibulares comunitários para negros e pessoas carentes, vinculados à Igreja Católica:

Eu fiquei acho que um ano nessa questão do trabalho voluntário, nessa questão da universidade. Na época, acho que foi em 2004 ou 2005, não tinha essa política de Prouni, de ENEM, então, a única forma dessas pessoas menos favorecidas acessarem era muito através de... Pela PUC... Então, a Educafro, ela tinha... Como tinha essa questão da Igreja Católica, ela tinha mais uma relação mais aproximada da PUC e da Bennett também. Então, estudando na Educafro, a gente conseguia uma cota para esses alunos se passassem nessas universidades, serem bolsistas, então a gente tinha um apelo. (Tarsila).

\footnotetext{
${ }^{48}$ Bairro do $1^{\circ}$ Distrito de Duque de Caxias

${ }^{49}$ Colégio 18 de dezembro, no $2^{\circ}$ Distrito de Duque de Caxias.

${ }^{50}$ Movimento Revolucionário 8 de outubro.
} 
Através desse conjunto de relatos é possível perceber que nas trajetórias desses professores militantes existem algumas semelhanças, entre as quais está a presença da Igreja Católica através da frequência aos grupos jovens, a ação nas CEBs e pastorais, e a influência que a teologia da libertação trouxe para suas vidas, despertando-os ao envolvimento com as questões sociais de seu tempo; o ingresso no PT, partido que correspondia politicamente às aspirações de sociedade cultivadas no movimento religioso. A presença da esfera política na universidade, seja na figura de professores ou no movimento de criação do centro acadêmico, também é um fator de convergência de algumas histórias de vida.

Diferente dos depoimentos que relatam o florescer da militância em meio à esfera religiosa, nas trajetórias de Armanda, Cora, Dandara e Frida, a religião não foi mencionada como algo significativo nesse sentido.

Também observei que o movimento comum era de prolongamento da atuação na igreja para outros movimentos sociais e/ou o sindicato e nunca o contrário, de modo que, ao avançarem em seu relato, o envolvimento com a igreja vai sumindo de suas falas, dando a entender que ocorre um afastamento desses militantes do universo religioso.

Esse distanciamento também foi notado por autores franceses (Sawicki \& Siméant, 2011, p. 230) que ressaltaram a dificuldade de "católicos mais engajados à esquerda" manterem uma militância religiosa. De acordo com eles, os católicos "penam cada vez mais para achar seu lugar nas instituições da igreja e transferem mais do que nunca seu engajamento para fora do âmbito paroquial, para a esfera familiar ou para associação sem qualquer vínculo com a instituição.”

Entre o conjunto dos depoentes, esse desligamento da esfera religiosa se excetua no relato de dois professores evangélicos, Mário e Cecília ${ }^{51}$, cuja atuação eclesial encontra-se em ascensão ${ }^{52}$, e de Francisca, que é espírita ${ }^{53}$. De modo geral,

\footnotetext{
${ }^{51}$ No município de Duque de Caxias e no Brasil tem crescido em quantidade e representatividade social as religiões evangélicas. Seria interessante perceber a relação entre esse crescimento e o movimento sindical, observando a atuação (ou não atuação) de professores evangélicos no âmbito sindical. No entanto, entre os entrevistados, apenas Mário e Cecília se declararam pertencentes a esse segmento religioso.

${ }^{52}$ Mário é representante de sua igreja no movimento contra a intolerância religiosa no município de Duque de Caxias, além de atuar em prol da causa LGBT, principal público da igreja que frequenta. Cecília desenvolve um trabalho eclesial de orientação aos jovens de sua igreja.

${ }^{53}$ Francisca diz ter recuperado suas origens religiosas "dos 50 anos para cá", hoje ela tem 69 anos, e é espírita.
} 
o que se apresenta é um declínio da atuação devocional, inclusive com falas relatando um completo rompimento com a religião:

Minha história na Igreja Católica foi em São João de Meriti. Lá, eu militei nesse período de 70, 72, 18 anos [de idade], uns 5 anos. Mas, depois eu mesma me aborreci porque eu achava que o padre não era muito dedicado às causas. [...] Queria falar a missa em latim, a gente reclamava. Aí, quando, naquela época, a gente, eu e mais alguém, começamos a sair pelo Brasil, a gente foi para o Espírito Santo, que a igreja lá estava bem aberta, bem moderna e eles estavam com uma experiência de comunidade de base, aí eu fui para lá. Nossa! [...] Quando a gente voltou para cá e viu, embora, a diocese era de Nova Iguaçu, que era Dom Adriano Hipólito, era um bispo muito dedicado, avançado. [...] Mas, nem todos os padres seguiam aquela orientação, se fechavam muito. E esse meu padre era assim, aí ele falava no sermão: "Essas pessoas que viajavam, por aí à fora e voltam com umas ideias estranhas e tal." [...] Nunca mais fui de igreja, fui de nada. E nesse período, já era o período que o movimento sindical estava em evolução. [...] E aí eu já era de Sepe, de sindicato e... O movimento partidário são as coisas que me deram novo alento. (Olga).

Eu era da teoria da libertação, hoje eu não creio mais na presença divina, na interferência divina nesse plano, não acredito nisso, e aí eu, está legal, mas e aí? Qual o sentido da tua vida, cara? Quer dizer, eu acredito nisso que a gente que dá o sentido para vida, não tem: "Ah, Deus tem um propósito na sua vida" - acho que não existe isso, ou você dá um jeito na sua vida ou você vai viver conforme a maré. E viver uma vida sem propósito, sem sentido, não tem sentido. E aí, o sentido que eu dei para minha vida foi mudar para... Foi lutar para mudar a realidade, então esse espaço [sindical] é um espaço privilegiado para fazer isso. (Galeano).

A expressão de Olga: "novo alento" e a fala de Galeano sobre "sentido da vida", relativas ao movimento sindical, são bastante expressivas do significado atribuído por alguns militantes à sua atuação no sindicato. No diálogo com esses professores, sobressaiu a questão da necessidade de participação junto à sua entidade de classe e o desenvolvimento de um compromisso ideológico com o magistério e com a educação para além dos limites da esfera religiosa e dos muros da escola.

Ao levar em consideração a teoria das estruturas de oportunidades políticas para analisar o contexto de criação e desenvolvimento do núcleo sindical de Duque de Caxias e o envolvimento dos seus filiados, é possível perceber que, como analisado por Xavier (2013, p. 67), a década de 1970 apresenta um contexto de fraturas no equilíbrio do poder que "ocupam lugar de relevo para a compreensão de fatores que contribuíram para a emergência da mobilização coletiva dos professores."

Gohn (2012b, p. 262) também ressalta a importância da análise do cenário sócio-político para compreensão dos movimentos sociais, pois "ele quem fornece 
os elementos conjunturais que explicam o processo interativo e a correlação de forças existentes." E continua:

O que Tarrow denomina estrutura das oportunidades políticas nada mais é que o contexto das pautas e agendas colocadas pelos movimentos e pelos órgãos públicos e empresas responsáveis por certos bens demandados. Consideramos que estas oportunidades políticas podem ser criadas pelos diferentes atores (movimento, Estado ou mercado privado) e são um dos itens do cenário sociopolítico. Elas representam sempre uma possibilidade de renovação e mudança e conferem aos movimentos os atributos de poder. Se trata de um tipo de jogo de forças em que se disputa não a construção do bem comum (infelizmente), mas a tomada de espaços sobre a produção, gestão e controle de uma infinidade de coisas (bem públicos, no caso dos movimentos sindicais; terra, no caso dos movimentos agrários e dos índios; direitos sociais que poderão redundar em novos encargos sociais, no caso do movimento das mulheres e dos negros; maior responsabilidade do Estado e cumprimento da legislação trabalhista no caso dos movimentos dos menores etc.). (Gohn, 2012b, p. 262).

Portanto, no período compreendido entre o fim dos anos 1970 até o início dos anos 1990, o declínio da ditadura militar, a busca pela redemocratização e pela consolidação da participação popular são os principais elementos que compõem essa estrutura de oportunidades políticas favorável às mobilizações sindicais. Tais elementos atravessam o relato dos professores, como pano de fundo de sua história de militância:

\begin{abstract}
O meu ensino médio, você está findando a ditadura militar, então as pessoas tinham muito medo. Inclusive, eu me lembro, na época que a gente ia criar o grêmio estudantil, o diretor me chamou para perguntar o quê que era aquilo, qual o objetivo e tal, o negócio era na maior inocência... Eu não tinha muito essa questão, até porque os meus pais também falavam sobre a ditadura militar, tinha uma professora que ficava falando muito de tortura e tal, só que eu nem me dava conta do que ela falava ali. Depois, quando eu fui votar, o meu primeiro voto é que me chamou atenção, "agora bem, vou votar em quem? O quê? E tal...". Aí, eu comecei a prestar a atenção nas coisas que ela falava e aquilo ali começou a fazer sentido, e aí, quando eu venho pra Caxias no primeiro concurso que eu passei... 20 dias depois estoura uma greve. [...] Eu botava a mochila nas costas, ia no sindicato, ele me dava uma relação de escolas e eu ia correr a escola... (Galeano).
\end{abstract}

Mesmo Cora e Cecília, que não tiveram acesso a famílias politizadas, participação no movimento estudantil, partidos políticos ou CEBs, encontravam-se em um contexto político de grande efervescência, de modo que é possível perceber nos relatos uma ânsia por participação que encontra amparo no movimento sindical docente, mediante o ingresso no magistério público em Duque de Caxias:

Quando eu conheci o sindicato... Que eu logo assim que eu entrei para Caxias, eu fui convidada para... Trabalhava no Barro Branco. Eu fui convidada a participar das assembleias. E nas assembleias eu comecei a ver que movimento era esse, que espaço era esse de luta, que a gente conseguia conversar, que a gente conseguia cada um 
apresentar a sua proposta, a sua opinião, eu achava aquilo o máximo. Então, as pessoas poderem falar, discutir, um defender uma proposta, outro ir lá, defender contra e réplica e tréplica... E no final, vota. Isso me pareceu um espaço muito participativo dentro de tudo que eu sempre quis, que é isso mesmo, a gente poder discutir as coisas que são para o coletivo. [...] Eu comecei a ir, nunca faltei, todas as assembleias eu estava presente, sempre procurando chegar no início, sair no final, me posicionando nas vezes que eu tinha que me posicionar... (Cecília).

Eu comecei primeiro em Nova Iguaçu, como professora, mas eu te digo mesmo: em um ano que eu fiquei na escola de Nova Iguaçu, eu nunca tinha ouvido falar em Sepe. Não estou falando mal do núcleo de lá, não. Estou dizendo que a minha escola era muito afastada, e a diretora, acho, também não dava muita abertura. Nunca ouvi falar em Sepe, lá. Eu só vim conhecer o Sepe quando vim para Caxias. Por quê? Eu vim para Caxias, comecei a trabalhar e logo nos primeiros meses uma professora bateu na minha porta: "Olha, nós vamos ter uma assembleia..." [...] E ela me falou: "Ó, vários professores vão lá e tal para a assembleia." [...] "Sindicato dos Profissionais da Educação, eu tenho que conhecer! Eu vou." Botei meu nome que ia e fui na primeira assembleia. E aí, eu não parei mais. (Cora).

Xavier (2013, p. 65) menciona que durante o período de redemocratização, professores atuantes nos sindicatos do Rio de Janeiro "trouxeram à tona a importância atribuída por alguns militantes ao trabalho de mobilização política desenvolvido no interior das escolas." Todo esse trabalho de mobilização política dentro das unidades escolares fica explícito na fala de Zilda:

Você se engaja na luta, mas, sempre pensando a escola, claro, nas questões salariais, nas condições de trabalho, isso é sempre pauta, mas a luta que a gente leva até a década de 90 , até o final da década de 80 são lutas... O foco na escola é muito forte. Tanto, que a eleição para diretor é uma coisa importante e eu me lembro, que quando eu entro na escola em 85 uma das nossas reclamações, o grupinho que começa a se articular, era da falta de reunião da escola, a escola não fazia reunião, aí a gente ia conversar com a OP da escola... Quando você vai ver isso depois, isso não se dá só nessa escola, mas se dá em outras. [...] Porque tinha essa preocupação em transformar as relações dentro da escola, transformar o espaço pedagógico, isso está muito entranhado. Então, assim, eu vejo, quando eu falo da formação do sindicato, mas é o quanto essas lutas ajudaram, naquele momento, é... A transformar a escola e na aposta que a gente fazia da escola como um espaço possível de ser transformado, possível de ser constituído. [...] A minha grande escola... Quando eu penso assim, tantos anos de trabalho, eu já rodei muitos lugares, mas o grande marco de formação foi a escola estadual dentro desse contexto, de organização, de luta, de reflexão. (Zilda).

Do mesmo modo, apesar do arrefecimento da mobilização sindical no contexto nacional (Dal Rosso, 2013) e local (Simões, 2000) aqueles professores de uma geração mais nova, que ingressaram posteriormente da rede municipal de Duque de Caxias, como Tarsila, Mário e Rosa, encontraram um clima favorável à participação, construído pelos que vivenciaram esse período fértil de luta pela democratização e levado a diante por aqueles que se incorporavam ao movimento: 
Eu entrei em 2004... A escola não era muito de mobilização e eu nem sabia de sindicato. Aí, em 2005 que eu comecei a participar mais, vir nas assembleias. Eu comecei na EJA em 2006 e o pessoal já me conhecia... Tudo que tinha na SME sobre a EJA, as pessoas me chamavam para falar em audiência, para falar do ponto de EJA, e aí foi a partir disso... Eu fui me aproximando das pessoas e de vez em quando: "Ah, Tarsila, vem para uma chapa." E eu: "Não, não quero." Sempre dava uma desculpa. [...] Aí, na outra eleição, não tive mais como falar. "Nessa, eu venho!" Foi em 2012, a primeira gestão, até 2015, e de 2015 até o ano que vem, 2018; aí acaba a segunda. (Tarsila).

No Estado, eu participava das assembleias. [...] Não cheguei a pegar aquelas enormes do Maracanãzinho, mas ainda cheguei a pegar algumas na Concha Acústica, da Uerj, do Estado. Mas não atuava tanto na rede estadual, passei a atuar um pouco mais tanto que eu vim parar na direção - passei a atuar mais quando eu fiquei na rede municipal. [...] Eu fiquei como representante da escola acho que em um ou dois anos, foi por volta de 2004, porque 2006 foi quando a gente entrou na direção. (Rosa).

As relações entre pares estabelecidas na escola de ingresso e posteriormente no próprio sindicato foram fundamentais para o envolvimento gradativo na militância sindical.

Portanto, o ingresso de novos filiados à militância mais efetiva, ocorre via escolas mobilizadas, professores representantes que informam e convidam para a luta, e diretores sindicais, como Frida, que se constituem verdadeiros "introdutores" à vida sindical mediante acolhimento e incentivos à participação.

Frida e Oscar me chamam: "Você não quer dar o nome para participar da direção não?". Eu: "Não, não quero não." "Mas é só dar o nome, porque a gente está precisando completar a chapa." Aí eu falei: "Só dar o nome, Frida?" E ela: "É, só pra dar o nome.” [...] Aí, minha filha, nessa de dar o nome, já viu... Entrei na chapa, fiz parte da direção, já no primeiro ano, isso, já no primeiro ano eu fiquei com uma licença sindical numa matrícula. (Rosa).

A gente, na época, tinha a Francisca, Frida, Adélia, Cristiane, Clarice, é... Que era um pessoal, assim, que chamava para junto mesmo. Então, Frida sempre: "Cecília, vai lá... Cecília faz... O que você está falando é importante... Vai lá, pega o microfone e fala." Então, eu já recebi incentivo para colocar as minhas ideias e aí eu fui convidada para... 45 segundos do segundo tempo, para entrar e ingressar na diretoria; a princípio, eu tive medo porque eu não tinha experiência, não tinha uma vida militante. [...] Eu fui convidada e aceitei vir para a diretoria do sindicato e aí eu peguei uma época ainda que a diretoria tinha eleição de presidente, vice e tal, e eu fui eleita para ficar na tesouraria, então, eu já cheguei com o compromisso de organizar a tesouraria do sindicato. (Cecília).

No inventário sobre a sociologia do engajamento, Sawicki e Siméant (2011, p. 215) citam a presença de "introdutores" em estudos sobre o envolvimento sindical e humanitário, "indivíduos que contribuem para a materialização do engajamento e fazem a diferença entre aqueles que darão o primeiro passo e os outros." E os autores ainda ressaltam "a importância das redes sociais como suporte 
de sociabilidade e de novas identidades que contribuem para a eficácia e manutenção do recrutamento na ação coletiva."

Frida sempre foi uma pessoa extremamente acolhedora e acabei acompanhando mais. Aí, na eleição de 2010 ... Ela me chamou para compor a chapa e eu disse para ela que eu não me sentia preparado ainda, não estava pronto para assumir isso, não quis entrar, e aí em 2015 ela me chamou de novo e aí eu disse: "Está bom, vou." (Mário).

Até que eu, nessas reuniões que o sindicato faz, que está todo mundo lá... A direção... Era reunião de direção, eu não era diretor, mas eu trazia todos os informes, tal, tal, tal, tal, assim, e aí na hora que eles estavam discutindo para votar quais eram as posições, ficavam falando: "Vota aí, vota." Mas aí eu falei: "Não, eu não sou da direção."; "Você é diretor, Galeano!" - Frida [risos] - "Você é diretor de fato, você é diretor de fato, direção política." Essas coisas que ela fala hoje, ainda. [risos] E ali, eu fiquei super encantado com aquilo tudo e fui convidado na gestão posterior a entrar para direção do Sepe, aí, já naquele período, na primeira eleição que veio, eu entrei na chapa... (Galeano).

Observando as trajetórias, percebi que no caminho entre a introdução à participação sindical até a militância de fato, há, em geral, uma gradação do envolvimento, que se inicia brando e depois vai se intensificando. Nesse processo, o papel do "outro" é fundamental, seja ele um colega, um líder sindical, ou um sujeito coletivo, como a escola, e o próprio movimento sindical como um todo.

No relato de Mário, cuja experiência sindical, em termos de tempo, é mais curta, essas etapas aparecem com maior clareza. O primeiro passo é dado pelo representante de escola, que em geral, convence os colegas a participar das assembleias, ou o próprio clima da unidade escolar mobilizada, onde todos fazem greve e quem não adere ao movimento fica em destaque negativo.

Quando eu entrei para rede, isso em 2007, eu já comecei fazendo greve porque, para minha sorte, eu entrei numa escola onde a maioria das pessoas tinha compreensão da luta sindical, não vou dizer que eram militantes, mas compreendiam, pelo menos, a força que tem a participação dentro do movimento, no sentido de adesão às greves. [...] No meu primeiro ano, já teve uma greve no período da data-base, aí eu fiquei muito assustado, não entendia o que podia fazer, conversei com as minhas amigas e elas: "Não, olha só, você começou agora, mas a luta sindical é para todo mundo, pode entrar sim, participa e não vai ter problema nenhum." (Mário).

O segundo passo é dado com a participação nas assembleias que, em geral, despertam o sentimento de solidariedade, de mobilização para a luta, de discordância e indignação contra as ações governamentais, o desejo de se fazer presente, de receber informações, de pertencer a um coletivo, de se posicionar, de se fazer ouvir. 
Comecei na greve já em 2007, mas não estava engajado ainda, ia para as assembleias, mas era aquela coisa bem solta e alguns anos depois é que eu comecei, quando eu passei para o Ciep 227. [...] Lá é que eu comecei a ser o representante da minha escola. [...] E comecei a me tornar o cara chato que fica questionando um monte de coisa, que falava um monte de coisa, eu era muito efusivo nas minhas colocações dentro da assembleia, porque aí eu comecei a participar das assembleias, comecei a pedir fala, comecei a participar das avaliações e eu era muito empolgado naquilo... (Mário).

O terceiro passo diz respeito à participação no conselho de representantes, onde o professor desenvolve a capacidade de articulação interna e externa à escola, pois precisa pensar coletivamente com seus pares imediatos e propor sugestões para questões que envolvem toda a rede. No conselho, deverá pesar as colocações dos colegas e avaliar as circunstâncias em busca de proposições que abranjam e atendam as demandas colocadas.

Caxias é um dos únicos municípios que tem conselho de representante, que se reúne. Inclusive, a gente sempre monta chapa no Sepe, geralmente com bastante representantes porque o representante você vai formando... Depois, geralmente, os representantes passam a ser direção, e aí você vai tirando alguns representantes, e você vai construindo novas lideranças. (Frida).

O quarto passo é a "corrida às escolas" ou "comando de greve", onde uma equipe de professores de diferentes realidades locais se articula por distrito ou proximidade, e segue em direção às outras unidades onde há professores indiferentes à luta, temerosos ou frustrados, com quem deve dialogar, esclarecer, arregimentar.

O quinto passo, seria a ida às audiências ou a participação em comissões, onde o militante se vê comprometido com o andamento de ações propostas coletivamente nas assembleias, ao dispor do seu tempo, e/ou se colocar de frente com o governo em circunstâncias quase sempre desagradáveis, cuja intransigência, a falta de respeito e a inoperância de determinados governantes têm posto à prova a saúde e a paciência dos líderes sindicais, a quem esse professor deverá acompanhar e ajudar a representar os interesses de toda uma categoria profissional.

A Frida me chamou para ir a uma audiência, aí é que eu vi que o buraco era bem mais embaixo do que eu imaginava, porque aquela coisa de você estar na militância, ali na luta, você ser combativo, é muito legal, mas quando você chega na hora da negociação, não é assim, você diz e o governo cumpre. Eu vi que era muito mais complexo; a avaliação tinha que ser uma avaliação muito mais aprofundada e comecei a participar ainda mais efetivamente da luta, acompanhando mesmo, me aproximei bastante da direção nessa época. (Mário). 
Nesse caminhar, os sujeitos tendem a desenvolver outro olhar sobre o movimento sindical e sobre os seus dirigentes, assimilando e construindo novas formas de agir e pensar que constituirão sua identidade militante. Obviamente esse caminho não é trilhado da mesma forma por todos, mas de modo geral ele aparece presente no conjunto das experiências compartilhadas pelos professores militantes do Sepe/Caxias.

Na próxima seção, trato das memórias como fruto desse envolvimento com a militância sindical, que para muitos se constituiu uma parte relevante de suas vidas, ao mesmo tempo em que propiciou a construção de um dos mais importantes núcleos de sindicato docente do Estado do Rio de Janeiro.

\section{2 \\ Construção de uma história coletiva}

Em meio às histórias de vida de professores militantes, emergiram memórias do sindicalismo docente vivido em Duque de Caxias. Lembranças compartilhadas no grupo entre os atores mais velhos e os que foram se agregando ao movimento ao longo do caminho. Diante da riqueza desses depoimentos, encontrei em Bosi (1994, $2003)^{54}$ os fundamentos para a análise dessas memórias.

Alguns desses professores são fundadores do núcleo de Caxias, e outros se apropriaram dessa experiência pelo convívio com os membros mais antigos. Como colocado por Barbosa (1994) no prefácio à obra de Bosi (1994), a expectativa ao ouvir esses professores militantes, especialmente os mais velhos, é para além de colher, "dar existência às suas memórias", atendendo assim, a lamentos como o de Olga, que expõe sua preocupação com a perda das memórias do Sepe ao longo do tempo:

Não tem nada escrito sobre isso ${ }^{55}$, nada. É uma coisa que eu me arrepio, às vezes, porque não é a minha história, por acaso eu estava envolvida nela. E eu fico assim,

\footnotetext{
${ }^{54}$ Em seu livro "Memória e sociedade", publicado em 1994, Ecléa Bosi (2003) volta-se às memórias de velhos moradores da cidade de São Paulo dos primeiros decênios do século XX. Para análise dessas memórias, a autora se apoia na teoria da Gestalt sobre campos de significação na vida subjetiva e na vida intersubjetiva; nos estudos de Bergson que ressaltam a dimensão temporal da memória; em Halbwachs, a dimensão psicossocial da memória estabelecida nas relações com a família, o grupo cultural, a classe, a comunidade; e a teoria da ideologia, encontrada nos estudos de autores dialéticos, como Benjamin e Adorno.

${ }^{55}$ Nesse trecho da entrevista ela se refere a novas iniciativas de reposição criadas após a greve de 1979.
} 
me sinto mal em saber que eu vou morrer daqui a pouco e vou levar isso... Não é minha história... (Olga).

$\mathrm{Na}$ certeza de que as pessoas partem e se não há registros, uma parte da história morre com elas, Olga anseia por ver as experiências vividas ao longo da trajetória do Sepe eternizadas pela escrita, pois "quando as vozes das testemunhas se dispersam, se apagam, nós ficamos sem guia para percorrer os caminhos da nossa história mais recente: quem nos conduzirá em suas bifurcações e atalhos?” (BOSI, 2003, p. 70). Assim, o registro das memórias daria "existência escritural à fala" dos depoentes, mantendo a história viva (BOSI, 1994).

A preocupação com as memórias também pode ser apreendida com a observação de determinadas atitudes, como a de Frida que, em meio a uma assembleia, apareceu com uma mala na mão repleta de materiais que remetem a formações organizadas pelo Sepe ao longo dos anos, também com alguns materiais do partido político que mais influenciou os componentes de sua chapa. Ela me passou esse material como relíquia, na certeza que eu iria reconstituir a "história do sindicato". Frida mora em Niterói, há 32 quilômetros de Duque de Caxias. Não possui carro, vem de transporte público e ainda assim, teve a preocupação de separar parte do que acredita ser importante na trajetória sindical docente de Duque de Caxias, e me dar para ser analisada.

Desse modo, além das falas das entrevistas trago anotações do caderno de campo, onde registrei lances como esse e também recordações espontâneas, cenas em que a memória dos participantes vem à tona, trazendo um pouco do entrelaçar das lembranças pessoais com as memórias do Sepe/Caxias:

Hoje foi um dia carregado de memórias, primeiro a Frida, foleando álbuns do Sepe após o Conselho de Representantes, enquanto conversámos na varanda da sede. Ela mostrava um pouco do muito que se fez nos velhos tempos, lembranças de 1991, 1999, 2003... Eleições de direções, greves, passeatas, formações e festividades, fotografias onde estão presentes professores que militam até hoje, como ela mesma, e outros saudosos que já partiram. A cada página virada, uma memória que nem sempre Frida recordava dos nomes, mas lembrava da história da qual falava com empolgação. Ver-se e olhar os seus companheiros, admirando as mudanças nos traços, nos cabelos, no corpo, na história de cada um, foi muito bonito. Deu vontade de ficar ali, admirando o álbum e ouvindo as recordações de quem vivenciou o sindicato, construindo-o a cada ano de sua vida. O segundo momento que marcou o dia, foi quando voltávamos da câmara de vereadores, acompanhando Francisca, que iria a pé até a casa de sua irmã onde passaria a noite. No caminho, ela dizia como o sindicato marcou sua história, do quanto ela se modificou após o convívio com o sindicato. Nas palavras dela: "Foi no sindicato que me formei, aprendi a votar, aprendi que não precisava votar em quem meu marido ou meu pai mandava. Minha 
formação política foi aqui." Entre as memórias que lhe vieram à tona, achei essa fala bastante significativa. (Diário de campo, 27/06/2017).

Como é possível notar, as memórias da instituição e das ações sindicais desenvolvidas ao longo dos anos se misturam também às lembranças pessoais, como aprendizagens e relações de amizade estabelecidas em meio ao movimento sindical docente.

Sobre a relação entre lembranças individuais e coletivas, Halbwachs (1990, p. 51) ressalta a natureza social que as mantém ligadas:

Se a memória coletiva tira sua força e sua duração do fato de ter por suporte um conjunto de homens, não obstante eles são indivíduos que se lembram, enquanto membros do grupo. Dessa massa de lembranças comuns, e que se apoiam uma sobre a outra, não são as mesmas que aparecerão com mais intensidade para cada um deles. Diríamos voluntariamente que cada memória individual é um ponto de vista sobre a memória coletiva, que este ponto de vista muda conforme o lugar que ali eu ocupo, e que este lugar mesmo muda segundo as relações que mantenho com outros meios. Não é de admirar que, do instrumento comum, nem todos aproveitam do mesmo modo. Todavia quando tentamos explicar essa diversidade, voltamos sempre a uma combinação de influências que são todas de natureza social.

De fato, mesmo as lembranças em comum não são iguais para todos os membros do grupo. Os mais velhos parecem trazer com mais força a memória e o zelo pela sua manutenção. Digo isso porque foi possível notar no conjunto de depoimentos que existe por parte dos mais antigos no movimento sindical uma preocupação com a história do núcleo. O desconhecimento ou desvalorização dessa história pelos mais novos é a razão de alguns conflitos.

A gente comete um pecado enorme com a memória do sindicato, a gente tem acúmulo de lutas, uma coisa vasta, fantástica... Porque normalmente quem entra, quando vê o que tem, vê uma fotográfica, só que não percebe que está carregado de memória, de história, de luta, de sacrifício, é... De noites perdidas... De você sair de madrugada fotografando, mãe dormindo em porta de escola, então, isso tudo a pessoa só vai conhecer se for apresentado, se for contada. (Galeano).

A história da gente em Caxias é uma história de respeito. É uma história que tem que ser respeitada mesmo, mas uma parcela mais nova da categoria desconhece a nossa luta. Desconhece a nossa luta. Eu não estou me referindo a pessoas exatamente, mas à luta do sindicato. [...] Esse último concurso foi revelador, as pessoas já queriam escolher escolas com dificílimo acesso, botar outra matrícula no difícil acesso, o enquadramento, as pessoas já vieram fazendo $\operatorname{contas}^{56}$. Não é de desconsiderar não,

\footnotetext{
${ }^{56}$ A lei ${ }^{\circ}$ 1.070, promulgada após acordo de data-base em 1991, estabelece o plano de carreira dos profissionais da educação de Duque de Caxias. Considerado um dos melhores planos entre os demais municípios do Rio de Janeiro, prevê enquadramento por formação, tempo de serviço e gratificação aos profissionais da educação lotados em escolas consideradas de "difícil" ou "dificílimo acesso". No curso da pesquisa, essa lei sofreu uma alteração, através de um projeto enviado à câmara pela prefeitura, retirando alguns dos direitos estabelecidos.
} 
porque é nossa realidade de vida, a sobrevivência nesse mundo... É meio que a categoria, uma parcela, entrasse na rede, achando que isso caiu do céu, desconhecendo que cada centímetro dessa rede foi conquista da luta do Sepe. E a gente pode enumerar, assim, cada tijolinho que foi colocado. E a maioria desconhece, sabe das conquistas, mas não sabe os processos. Quando a gente não conhece a história, a gente não valoriza. (Clarice).

De acordo com Bosi (2003, p. 73), “a memória oral é fecunda quando exerce a função de intermediário cultural entre gerações.” Durante as observações, notei algumas ações em direção ao resgate dessas memórias e como exemplo cito dois encontros: o primeiro com os novos concursados e o segundo com os especialistas (orientadores pedagógicos e educacionais). Em ambos, houve uma parte da reunião dedicada à história do movimento sindical em Duque de Caixas, em que membros antigos da direção sindical recuperavam as principais pautas, lutas travadas e conquistas alcançadas. No entanto, há dificuldades em desenvolver esse tipo de trabalho com toda a rede de ensino. Nos exemplos acima, o público era restrito; na plenária de orientadores compareceram apenas 20 pessoas, sendo que 7 delas compunham a direção do sindicato e no encontro destinado aos novos concursados dos 800 convocados, compareceram cerca de 30 pessoas.

Nessa iniciativa de ensinar aos mais novos os acontecimentos importantes da história do sindicato, subjaz a tentativa de manter o grupo coeso e não dispersar o movimento com uma possível fragmentação entre as gerações, pois como cita Halbwachs (1990, p. 82) sobre a negação ou surgimento de novas memórias não partilhadas pelo grupo: "não é um mesmo grupo que esquece uma parte de seu passado: há na realidade, dois grupos que se sucedem.” O autor traz a ideia de "memória coletiva", que consistiria no reconhecimento da estabilidade das relações desenvolvidas pelos membros de um determinado grupo em um dado tempo e espaço, cuja recorrência das ações e, por conseguinte, recordações, lhe confere certa identidade. Para Halbwachs (1990, p. 82), a memória coletiva “é uma corrente de pensamento contínuo [...] que retém do passado somente aquilo que ainda está vivo ou capaz de viver na consciência do grupo que a mantém."

Assim, percebi que algumas imagens e acontecimentos recorrentemente evocados pelos membros Sepe/Caxias em seus relatos são importantes para essa coletividade, enquanto símbolos da identidade do grupo.

No entanto, como coloca Pollak (1989) ao criticar a "durabilidade, permanência e coesão", presentes no conceito de memória coletiva de Halbwachs, 
a memória está constantemente "em disputa". Para o autor, é preciso ouvir as memórias subterrâneas e estar atento aos "não ditos", aos conflitos e competições de memórias concorrentes em detrimento da uniformização proposta por uma "memória oficial".

No caso do campo de estudos em que se insere esta tese, um exemplo dessa "disputa" de memórias é a data de fundação do núcleo caxiense do Sepe, relembrada por muitos como sendo a partir da incorporação da APPMDC ao Sepe, mas, segundo Olga, essa data ignora o movimento anterior ocorrido no município, com a participação de membros do Sepe da rede estadual que também atuavam em Duque de Caxias:

Esse foi um dos meus traumas, que quando eu saí daqui para ir... Dirigir o estadual, eu era muito dedicada, eu viajava por tudo quanto era canto e... E aqui deixei uma direção praticamente construída. Mas, em 85 eles fundaram uma associação aqui, que era para o Sepe ser contra, categoricamente contra, e quem estava lá na assembleia, os que estavam e que achavam que não tinha que criar aquela associação, não tiveram forças pra combater porque passou toda uma visão de que o Sepe era da rede estadual; então, a rede municipal precisa de um sindicato municipal, mesmo todo mundo sabendo que o Sepe representa as duas áreas, as duas redes, e eu não estava nesse dia, que era um dia de uma atividade no Sepe estadual, e eles fundaram a APPMDC. Tudo bem, fundaram, durou até 92. [...] Mas, uma coisa é que comece a contar a história da categoria de 80 pra cá, que foi quando ela fez a primeira greve. Outra coisa, é que você comece a contar de 85, quando fundou a APPMDC, aí, é você enterrar a luta do Sepe e a luta da categoria. E se você for perguntar a várias pessoas, inclusive a essas meninas novas que estão na direção hoje, elas não sabem da história, mas por que as mais velhas não contaram? (Olga).

Nas palavras de Olga, está posto o conflito que envolve não só a data de fundação oficial, mas também as ações lembradas ou não pelo grupo. Esse "apagamento" é encarado por ela como um "trauma". Nesse sentido, foi preciso ter sensibilidade aos sentimentos relatados e expostos através dos gestos e olhares que representavam o quão tocante pode ser para um depoente remexer em suas memórias. De acordo com Pollak (1989, p. 6), "para poder relatar seus sofrimentos, uma pessoa precisa antes de mais nada encontrar uma escuta" e me parece que Olga viu na ocasião da entrevista, a oportunidade de ser ouvida.

No relato de Zilda, a questão do conflito não emergiu. Para ela, o processo de transição da APPMDC para o Sepe ocorreu com tranquilidade e fez parte de uma discussão maior, que é a unificação dos trabalhadores da educação:

A gente tinha, na época, uma referência de militância importante aqui para essa unificação porque era uma militante muito reconhecida na base da categoria, que também era militante da rede estadual, então, essa ponte de discussão, ela... Ela é feita com muita tranquilidade. E o processo também de muita discussão com a 
categoria, seminários de preparação até, que a categoria aprova unificação com o Sepe. (Zilda).

Diante de duas posições distintas sobre o mesmo fato, alcancei em Bosi (2003, p. 65) o equilíbrio necessário para seguir a pesquisa, valorizando cada depoimento:

Qual versão de um fato é a verdadeira? Nós estávamos e sempre estaremos ausentes dele. Não temos, pois, o direito de refutar um fato contado pelo memorialista, como se ele estivesse no banco dos réus para dizer a verdade, somente a verdade. Ele, como todos nós, conta a sua verdade.

Assim, conforme a autora sugere, eu me despi de pré-julgamentos e tentei trazer a riqueza das memórias dos depoentes em suas similitudes e divergências, sem ignorar os conflitos presentes nessas memórias, como adverte Pollak (1989), mas também observando as permanências que constituem a identidade do grupo, conforme sugeriu Halbwachs (1990). É válido destacar que "a memória oral, longe da unilateralidade para a qual tendem certas instituições, faz intervir pontos de vista contraditórios, pelo menos distintos entre eles, e aí se encontra a sua maior riqueza." (Bosi, 2003, p. 15).

A divergência dos pontos de vistas não são apenas reconstruções do passado, elas se rementem também ao presente do movimento sindical e apontam projetos de futuro. Para Bosi (2003, p. 67), "a nostalgia revela sua outra face: a crítica da sociedade atual e o desejo de que o presente e o futuro nos devolvam alguma coisa preciosa que foi perdida."

Eu acho que a diretoria que nós tínhamos antigamente, ela era muito mais envolvida nas questões do social e, assim, muito mais preocupada com essa coisa dos direitos e deveres e isso fazia diferença na militância. Hoje, eu vejo muitas das vezes, uma atuação muito latente nos espaços de assembleia, mas que falta nos outros espaços. Quando eu entrei em 91, o correr escola era uma coisa muito mais do cotidiano da direção, então, a direção corria escola, a direção tinha um respeito para com a escola. Embora, a gente chegava em escolas que estava todo mundo trabalhando, mas a gente pedia para reunir os professores, conversava, gente fazendo cara feia, mas a gente chegava, conversava, apresentava o porquê, a gente estava naquele momento, o que aquilo significava, e isso era muito mais frequente com toda a diretoria. (Cecília).

$\mathrm{Na}$ fala saudosa de Cecília sobre as questões sociais e a prática chamada de "corrida às escolas" é possível notar também um tom de crítica aos caminhos tomados pela direção atual, e no decorrer de seu depoimento, a proposição de que essa aproximação entre direção e base seja retomada. Assim como ela, Elis também se baseia nas lembranças para pensar o presente e também o futuro: "eu acho que 
agora o sindicato tem que estar mais presente dentro das escolas, como já esteve no passado." Para Bosi (2003, p. 66), a memória pode deixar de ter um caráter de "restauração" e passar a ser "geradora de futuro".

Divergências à parte, entre os fatos recordados, as conquistas e avanços apresentam certos consensos entre os narradores quanto à superação das dificuldades iniciais, a importância da conquista do plano de carreira, e força da categoria docente:

Quando a gente começou, que não tinha nem essa sede aqui, que essa sede aqui veio depois, que a gente alugou e começou e nem era desse tamanhão. [...] A gente não tinha uma xerox para fazer as nossas cópias... Tudo era feito com muita dificuldade, se a gente precisava de fazer uma camiseta, por exemplo, a gente tinha dificuldade, hoje não. (Cecília).

A década de 80 , ela é rica nessa reflexão das lutas. Isso é muito forte, está muito presente, eu até acho que a gente conseguiu de uma maneira ampliar, talvez, em termos de organização... A gente criou a direção educacional nos sindicatos, em determinados momentos isso é mais forte... Aqui em Caxias se conquista o Cepemhed e o centro de... Os museus de... É fruto dessa reflexão, é fruto de... Tem sujeitos especiais aí nessa história... Mas, é fruto dessa preocupação, que a gente tinha na organização sindical, que o contexto na década de 80 permitiu. (Zilda).

Foi uma luta, a gente participou da luta do plano de carreira, eu participei... A gente construiu aquilo ali. Aqueles benefícios e tudo mais... (Nise).

A gente nunca precisou pedir licença, nossa história inclusive é essa, começamos a greve embaixo de uma ditadura militar que todo mundo sumia, era morto, era deportado e o que nos salvava era justamente ser coletivo. (Olga).

O patrimônio construído, não apenas material, mas simbólico, como a sede, o plano de carreira e tantas outras conquistas que diferenciam o núcleo sindical de Duque de Caxias dos demais, foram sendo estruturados mediante a organização contínua de movimentos como a greve em meio à ditadura militar, relembrada por Olga. São lembranças como essas, trazidas não apenas nos depoimentos concedidos a mim, mas também em assembleias, atos e outras reuniões, que vão trazendo motivação para a continuidade do movimento sindical, mesmo em meio a circunstâncias políticas adversas como a que vivemos hoje. ${ }^{57}$

\footnotetext{
57 Em âmbito nacional, ocorre a reforma previdenciária e trabalhista, entre outras, retirando e flexibilizando direitos consolidados. E no município de Duque de Caxias, no mês de agosto de 2017, o prefeito Washington Reis criou e sancionou dois projetos de lei: o primeiro, reduzindo drasticamente a progressão entre os níveis de $12 \%$ para $6 \%$, além de outras gratificações; e o segundo, aumentando a contribuição previdenciária. Após dois meses e meio a progressão entre os níveis foi recobrada, gerando grande polêmica em torno das estratégias adotadas para tanto, pois a
} 
Outra iniciativa em direção à valorização e conservação da memória, não apenas do Sepe/Caxias, mas também das instituições escolares nas quais atuam seus filiados, é a luta pela criação do Centro de Pesquisa, Memória e História da Educação em Duque de Caxias (Cepemhed).

Tuão (2016) relata que essa preocupação nasceu em meio à "corrida às escolas" na data-base de 2003, quando foi dado início ao processo de construção de um centro de memória no município que se propunha a catalogar e guardar os documentos das práticas escolares presentes no município desde sua constituição.

O trabalho desenvolvido no Cepemehed propõe-se a perguntar: que agentes constituíram a educação no município de Duque de Caxias? Que movimentos a constituíram? O que se retira, seleciona, esquece? O porquê das escolhas? [...] O Cepemhed procura, em suas ações trazer à tona essas memórias silenciadas, esquecidas, que contam outras histórias sobre o processo de escolarização na cidade [...]. (Tuão, 2016, p. 8,10).

Hoje, após muita luta e reivindicações sindicais com fins à consolidação desse projeto, o Cepemehed oferece formação e educação patrimonial à comunidade escolar, estimulando a resgatar e conservar as memórias de sua unidade escolar.

Na seção seguinte, abordo os diferentes níveis de participação encontrados no movimento sindical docente na atualidade, tomando por base as trajetórias sindicais, os dados dos questionários e as observações realizadas no campo.

\section{3 \\ Engajamento e atuação sindical}

Aqui destaco as formas de participação e envolvimento sindical, indicando as diferentes posições ocupadas no campo, os deslocamentos e conflitos gerados nas relações entre pares, nas escolas, com o poder público e com a comunidade escolar.

São diferentes trajetórias de atuação no espaço sindical, algumas que se aprofundam no âmbito do sindicato, criam raízes e se fixam ao longo do tempo, outras que se deslocam para outros movimentos sociais, políticos e até religiosos.

O movimento sindical, em si, acaba apontando outros caminhos, até por conta mesmo do limite. Eu acho que a gente que está no movimento sindical tem o limite que é o corporativo, que é da categoria e que não dá conta, por isso que outros movimentos, desde o envolvimento partidário mesmo que vai pensar sociedade de

direção majoritária considerou ser mais rápido o caminho político, enquanto uma nova oposição se articulava e insistia que o caminho mais eficaz seria o jurídico. 
uma maneira mais ampla. [...] Muitas vezes a gente diz: "O sindicato não é partido político." Então, o sindicato não tem como estar tomando determinadas posições porque ele tem que ser interlocutor da categoria. Então, acho que os outros movimentos vêm muito nisso, entendendo que o movimento sindical vai ter algumas limitações, que aí a gente passa a militar no movimento de mulheres, passa a militar no partido... (Rosa).

Eu milito no sindicato, milito também na minha igreja, parece meio contraditório, militância dentro da igreja, mas a postura de cristianismo que eu acredito é a postura de militância, de reconhecimento de que as populações mais pobres são aquelas que são mais abandonadas pelo Estado e que estão necessitadas do olhar de Deus; mas não que a gente deva simplesmente olhar e orar por isso. Eu acredito numa igreja que precisa denunciar o Estado, e aí a gente milita também nesse campo, principalmente na questão de direitos humanos e em especial para a comunidade LGBT, que é uma comunidade para quem a minha igreja tem um olhar mais cuidadoso porque é uma população muito marginalizada. Então, milito nessa questão; e desde o ano passado eu também entrei na Comissão de Combate à Intolerância Religiosa, aqui do município de Caxias. (Mário).

Para Gohn (2012b, p. 264), participação é uma das categorias teóricas importantes para o estudo dos movimentos sociais. Essa categoria foi muito utilizada enquanto "imperativo nas relações sociais" vigentes no período de redemocratização se tornando "um dos principais termos articuladores no repertório das demandas dos movimentos."

Em que pese o termo ter sofrido um desgaste, sendo inserido no jargão popular e apropriado por discursos políticos (Gohn, 2012b), resgato sua importância para a investigação em curso, incorporando-o ao questionário aplicado durante a data-base. Para tanto, abordo um conjunto de questões a respeito da participação sindical, a começar pela filiação, passando pela atuação ao longo da trajetória de militância e, mais especificamente, na data-base de 2016, quando os questionários foram aplicados.

Entre os 213 respondentes do questionário, 166 eram filiados, 45 não eram filiados e dois não responderam. 


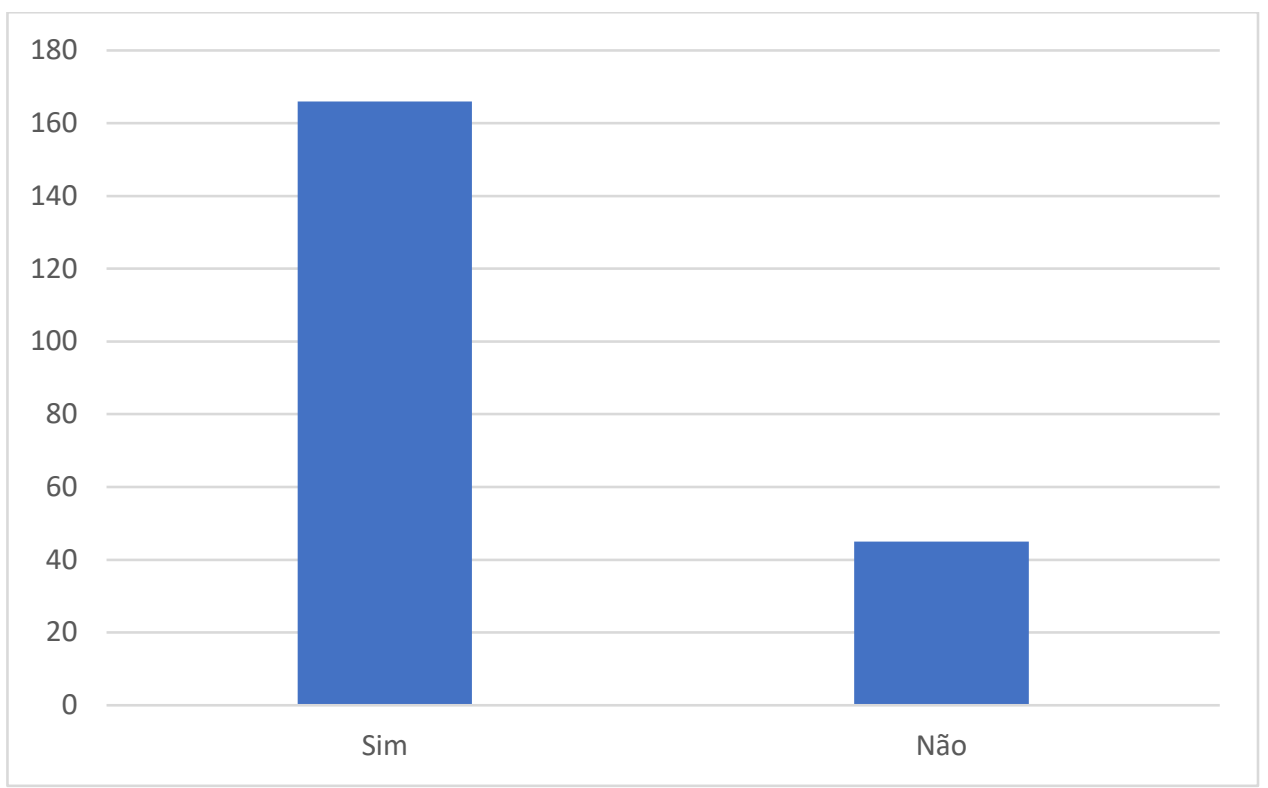

Gráfico 2 - Filiação ao Sepe

Fonte: Elaboração própria.

Entre as razões para filiação e para a não filiação foi apresentada uma série de explicações agrupadas pela recorrência semântica: nas 108 razões para a filiação estava expresso "o desejo de fortalecimento da categoria", "o sentimento de coletividade", "a credibilidade transmitida pelo Sepe/Caxias", "a importância da representatividade", e "a defesa dos direitos do trabalhador". Entre as 26 razões para a não filiação, cheguei às seguintes sentenças: "pensando sobre o assunto/avaliando", "sem vontade de se filiar ou desfiliado", "sem tempo ou esqueceram", "falta condições financeiras", "preencheram a ficha e não foram descontados" ${ }^{\prime 58}$. Vale ressaltar que 79 respondentes se abstiveram de expor suas razões.

Considerando o contexto de aplicação do questionário, assembleias organizadas pelo sindicato, a quantidade de 45 não filiados chamou a atenção, sobretudo ao levar em consideração as respostas obtidas sobre a representatividade sindical: 198 respondentes se consideram bem representados pelo Sepe, 5 não se sentem bem representados e 10 não responderam a essa questão.

\footnotetext{
${ }^{58}$ A filiação implica na concordância do repasse ao sindicato de $1 \%$ do vencimento descontado diretamente em folha - essa prática esteve vigente até $1^{\circ}$ de junho de 2017 , quando o prefeito Washington Reis decretou a suspensão desse repasse, dificultando o mecanismo de contribuição sindical voluntária.
} 


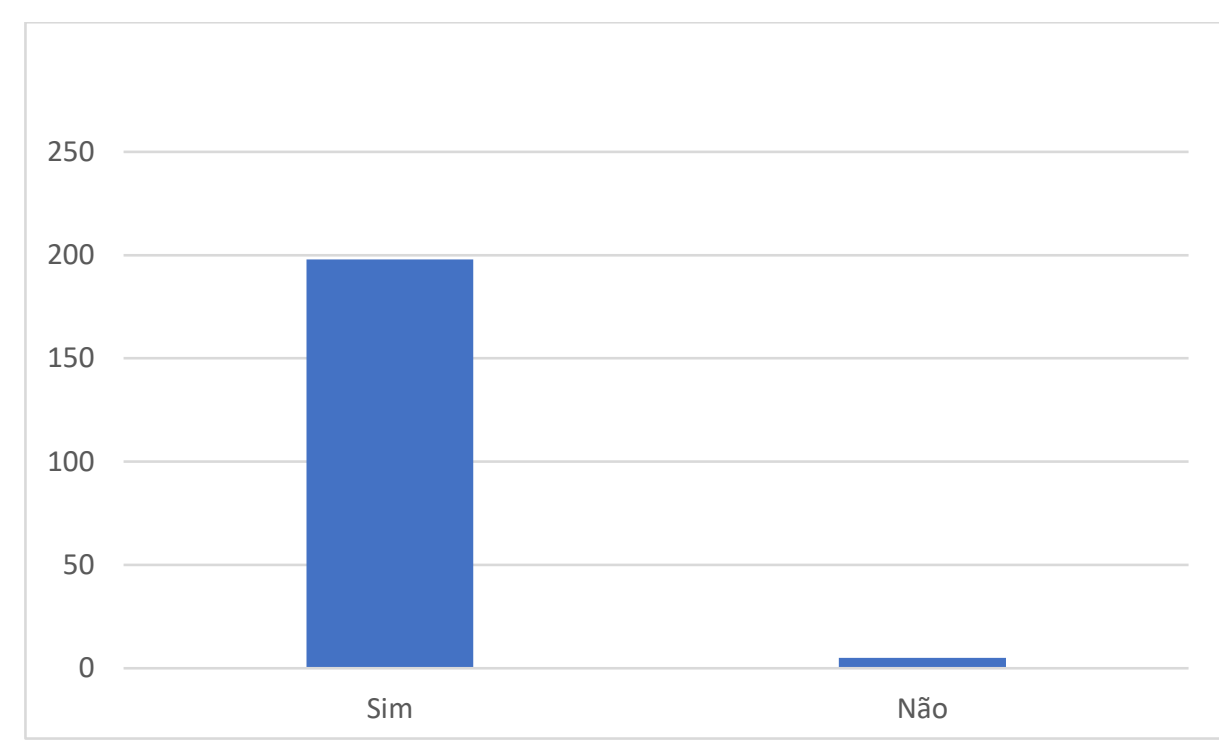

Gráfico 3 - Sentimento de representatividade dos filiados em relação ao Sepe Fonte: Elaboração própria.

O sentimento de representatividade é quase unânime entre o grupo de respondentes, indicando uma boa relação com o sindicato. Ainda assim, comparando as respostas do primeiro gráfico com as do segundo, é possível notar que há um grupo de não filiados que se sentem bem representados pelo sindicato, $o$ que poderia ser considerado um paradoxo, muito provavelmente ocasionado por um descolamento do sentimento de representatividade da necessidade de filiação.

A filiação é o primeiro passo em direção a uma trajetória de militância sindical, que envolve muito mais que essa ação inicial, mas a atuação e envolvimento nas questões sindicais. Assim, fica claro que o nível de engajamento na luta sindical não é o mesmo para todos os participantes. Ao questionar sobre a participação nesse espaço, obtive uma variedade de respostas: 


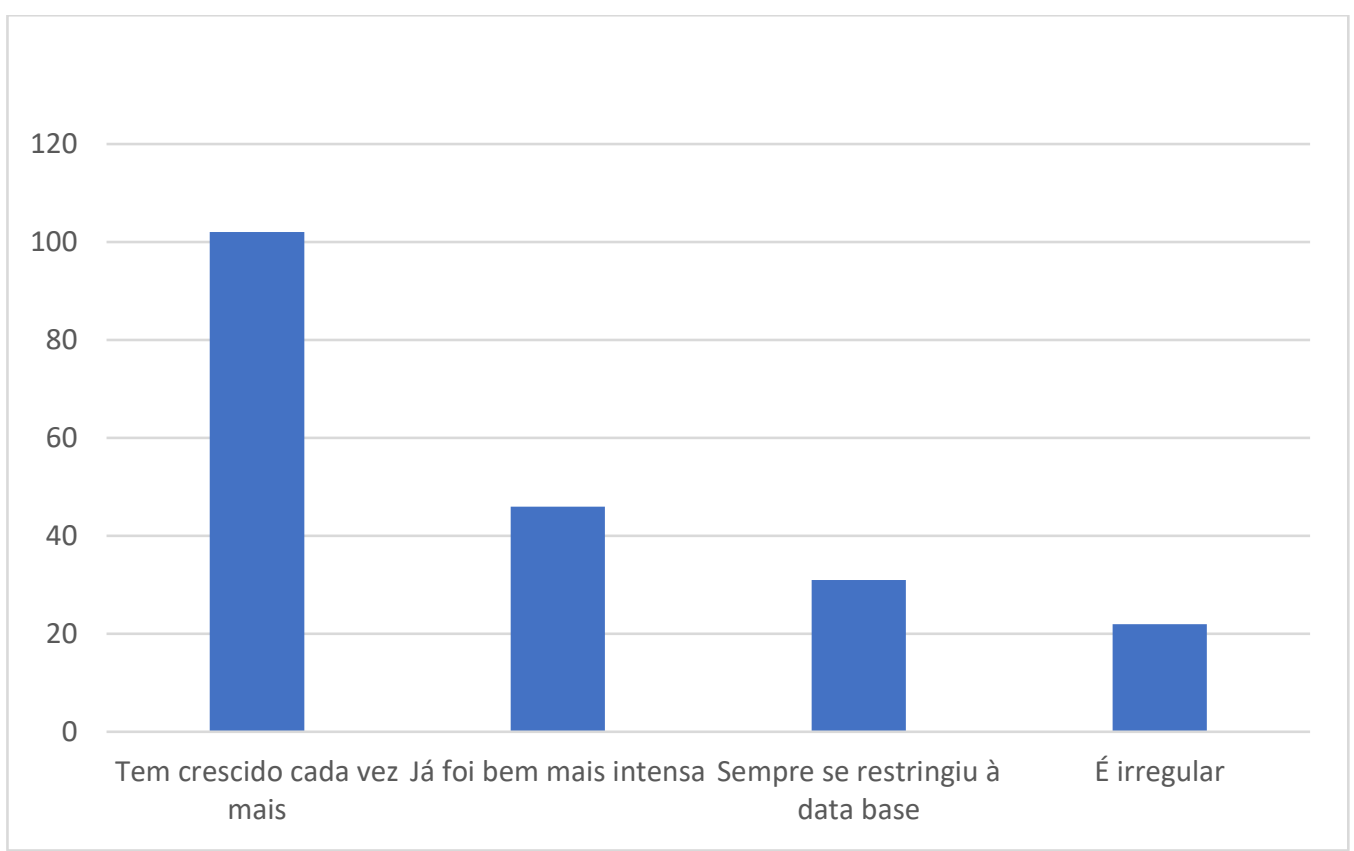

Gráfico 4 - Participação no sindicato

Fonte: Elaboração própria.

O Gráfico 4 reforça a questão dos diferentes estágios de participação no movimento sindical. Apesar de a maioria dos respondentes apontar que sua participação tem sido crescente, há aqueles cuja atuação encontra-se em declínio, os que só participam no período de data-base e os que apresentam uma participação irregular, oscilando entre momentos de mobilização intensa e a inércia.

Sawicki e Siméant (2011 p. 210) apresentam uma distinção entre o conceito de mobilização e engajamento que pode ajudar a compreender essas diferentes formas de atuação no movimento sindical docente:

As mobilizações não repousam unicamente naqueles que as fazem e que podem ser considerados mais engajados: o êxito de uma mobilização vem também do fato de que a ela se associam, além dos convictos, outros atores cuja mobilização é pensada na curta duração.

Assim, em períodos de maior mobilização, como greves, data-base, e reações às políticas de retirada de direitos, comparecem um maior número de pessoas que, em geral, não atuam em outros momentos menos críticos. Isso ficou bastante claro ao observar a frequência às assembleias ao longo do ano de 2016. Houve dois grandes períodos distintos de mobilização: o primeiro na data-base de 2016 que se iniciou em fevereiro e findou em abril (Gráfico 5), tendo como principal pauta a estrutura das escolas; o segundo compreende um conjunto de reações coletivas às questões salariais, como o escalonamento, parcelamento e atraso de salários (Gráfico 6). 


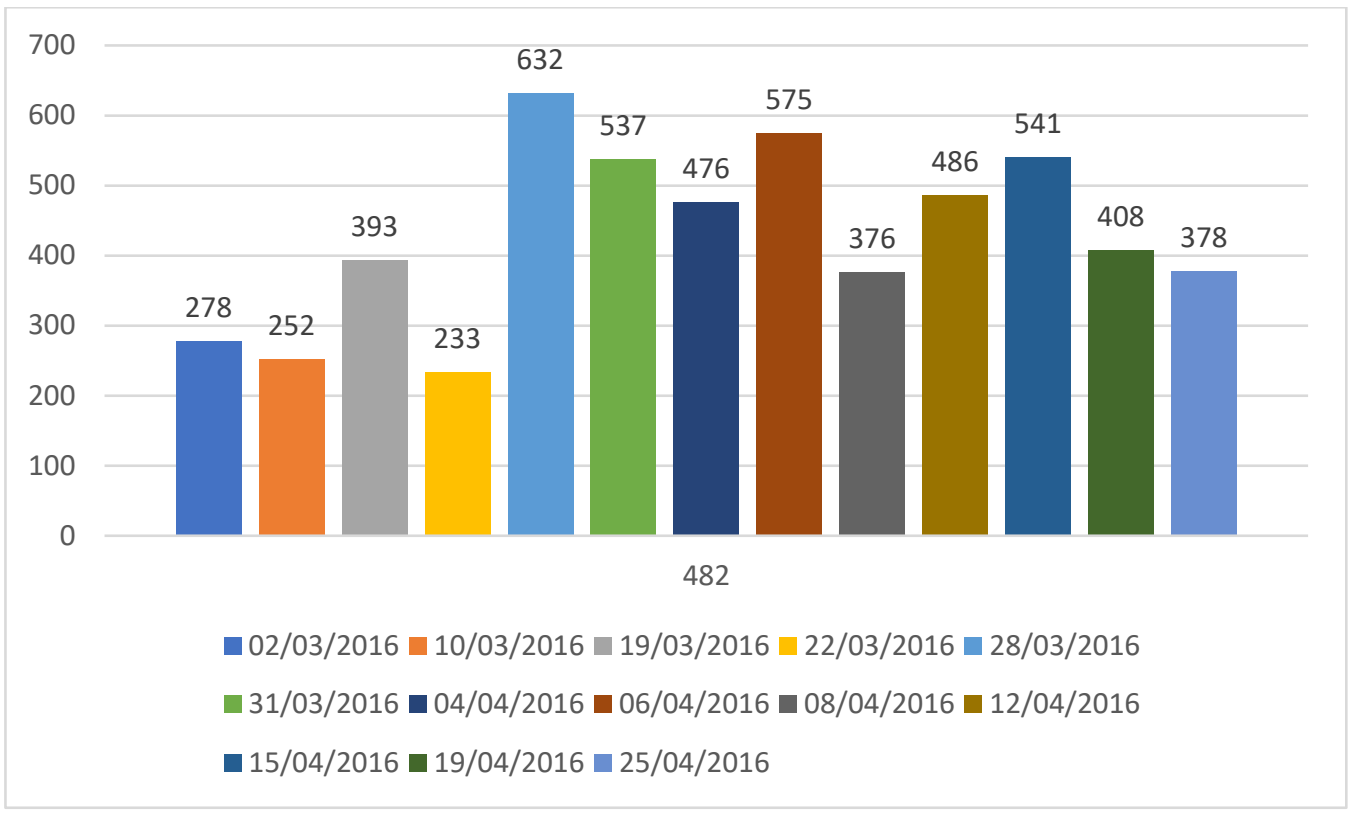

Gráfico 5 - Frequência às assembleias no período de data-base.

Fonte: Elaboração própria.

Historicamente, o período de data-base é o momento de maior mobilização no movimento docente em Duque de Caxias. Ao contrário disso, a luta contra constantes atrasos e parcelamentos de salários, era desconhecida até então pelos militantes deste município. Sendo assim, o Gráfico 5 mostra que no período de 28/03 a 25/04, quando se davam as negociações de data-base, havia a presença de um quantitativo médio de 490 participantes nas assembleias. E depois desse intervalo, como mostra o Gráfico 6, um novo período de mobilização se estendeu até o final do ano, com oscilações grandes na assistência às assembleias - de 78 a 633 presentes -, justamente no período em que houve o primeiro parcelamento salarial, em maio, e culminou com três folhas de pagamento em atraso, no fechamento do ano de 2016. 


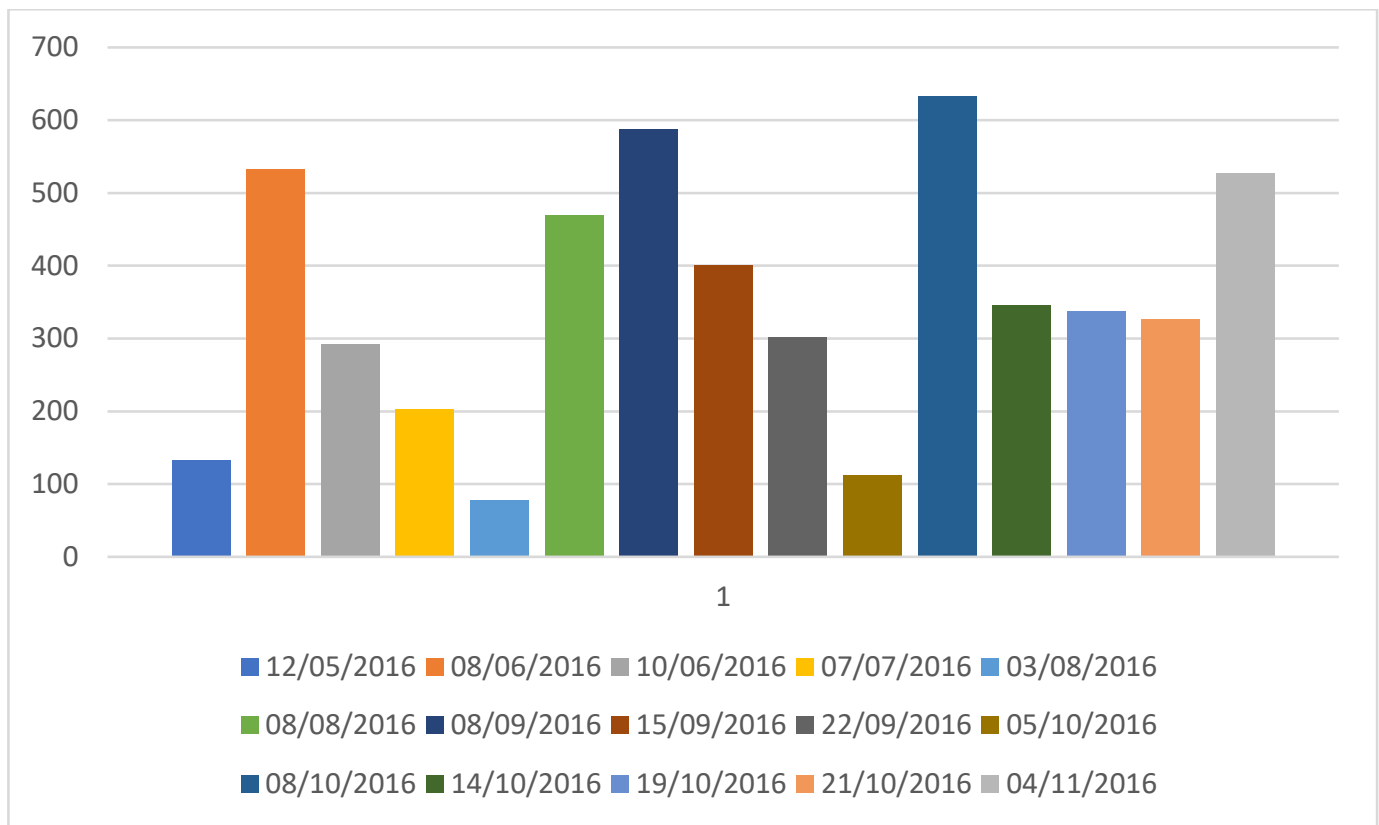

Gráfico 6 - Frequência no período de políticas de parcelamento salarial Fonte: Elaboração própria.

No diagrama apresentado a seguir, tento representar graficamente o que apreendi sobre o cruzamento dos dados dos questionários com as observações de campo e as entrevistas com base nas trajetórias sindicais, no que diz respeito à participação no movimento sindical. O nível de engajamento seguiria do centro à periferia e o núcleo do diagrama seria ocupado por aqueles cujo envolvimento é mais intenso e na periferia estariam os participantes menos atuantes ou instáveis.

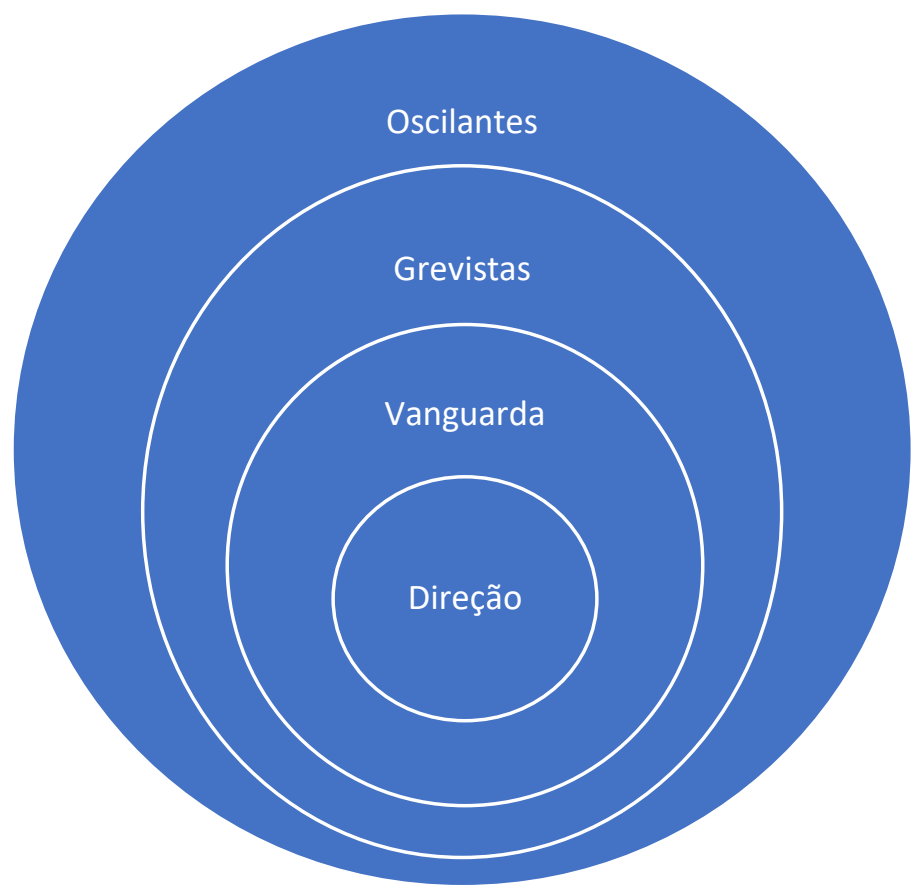

Figura 4 - Níveis de engajamento sindical Fonte: Elaboração própria. 
Os diretores sindicais encontram-se no centro do envolvimento sindical, não apenas pela posição que ocupam, mas pela intensidade do engajamento e disposição para realização das ações propostas no movimento sindical ${ }^{59}$.

$\mathrm{Na}$ vanguarda está um grupo que encabeça as ações e que auxilia na engrenagem sindical, como agentes difusores de ideias. Esse grupo se destaca por sua disposição à liderança, com falas contundentes em assembleias, produção de mensagens influenciadoras na internet, relação persuasiva ou conflitiva com os colegas de escola e participação nos atos e "comandos de greve", em busca de uma maior mobilização da categoria. Muitos deles representam suas escolas junto ao conselho de representantes. E embora apresentem essas características em comum, têm posicionamentos diferenciados entre si, uma parte voltada ao apoio à direção, e outra à oposição.

Chamei de grevistas aqueles cujo envolvimento está restrito à participação nas greves e data-base. Esses professores se envolvem com as atividades sindicais estritamente no período de greve, participando ou não das assembleias, aderindo a todas as paralisações com intuito de obter resultado nas pautas defendidas pelo movimento, mas sem necessariamente contribuir para o avanço destas. Parte dos grevistas não se inteira das discussões que vão além das questões salariais.

E na periferia do movimento estão os oscilantes, aqueles que se mobilizam com base em interesses mais superficiais ou específicos e são facilmente dissuadidos em função das circunstâncias momentâneas. Sua participação é menos efetiva e pouco politizada.

Esses diferentes níveis de participação e engajamento geram reflexos sobre as relações estabelecidas no interior do movimento sindical, possíveis de entender ao olharmos pela lente da perspectiva de Bourdieu (2004), como "campo concorrencial", e também na escola, onde esses sujeitos estão distribuídos de maneira desigual, podendo tanto estar agrupados entre militantes, quanto entre oscilantes.

Esses grupos não são estanques, havendo variação de posicionamentos entre os seus membros e intercâmbio entre os grupos ao longo da trajetória sindical dos

\footnotetext{
${ }^{59}$ Dentro desse grupo é necessário fazer a distinção entre aqueles que realmente engajados e outros cujos nomes apenas constam no quadro oficial da direção, pois alguns membros da direção atual iniciaram com participação ativa e por divergências ou questões de ordem pessoal, se afastaram do cargo ao longo do mandato.
} 
sujeitos. Desse modo, seu caráter é apenas ilustrativo do que foi possível observar, acompanhando o sindicalismo docente em Duque de Caxias.

Silva (2011) parte do conceito de habitus, de Pierre Bourdieu, para pensar o que chama de "habitus professoral". Para a autora, "os professores exibem ações/comportamentos no dia a dia que permitem ao observador identificar a que grupo de profissão o sujeito exposto pertence, sem que ele tenha oferecido informações a esse respeito." (p. 338). Ou seja, o professor incorpora um habitus profissional que o distingue dos demais. Nessa perspectiva, é possível também perceber dentro desse grupo profissional que, dependendo da frequência, nível de atuação e experiência sindical, os sujeitos constroem disposições que os distinguem daqueles que não são atuantes, visto que, para Bourdieu (apud Brandão, 2010, p. 232), "no social tudo é relacional".

Em 80, a gente foi mandada embora. [...] Eu ganhei uma carta para ir à secretaria estadual e elas ganharam turmas ali no Instituto de Educação, as três, por causa das greves. Eles não iam querer uma... Como é que eles chamavam na época? De baderneira... Uma baderneira do lado da "Metro ${ }^{60 "}$. (Olga, grifo meu).

Tanto os rótulos atribuídos aos professores militantes pelos "não militantes" e vice-versa são expressão de uma relação muitas vezes conflituosa. Assim, a identidade "sindicalista" construída ao longo da trajetória desses professores é também atribuída por seus pares na escola.

As perseguições, antipatias e problemas criados na escola devido ao "incômodo" que alguém mais crítico ocasiona nas relações escolares, não são maiores que a admiração de colegas, o respeito de alguns diretores e a comunidade escolar têm ao professor engajado. Assim, em uma relação dúbia, que ora tende ao rechaço, ora ao prestígio, o professor militante vê sua trajetória profissional marcada também pela sua trajetória sindical.

Claude Dubar (2005) constrói um importante quadro conceitual para a análise do processo de construção das identidades profissionais. Para ele, a identidade nunca é "dada" e sim construída. Seu ponto de partida é a dualidade social, traduzida em dois processos: relacional e biográfico.

\footnotetext{
${ }^{60}$ Abreviação popular de uma diretoria regional da Secretaria de Educação do Estado do Rio de Janeiro, conhecidas como "metropolitanas".
} 
No processo biográfico, o sujeito constrói uma identidade para si e no relacional, para o outro. Esses dois processos ocorrem de maneira inseparável e estão totalmente imbricados:

A divisão interna à identidade deve enfim e sobretudo ser esclarecida pela dualidade de sua própria definição: identidade para si e identidade para o outro são ao mesmo tempo inseparáveis e ligadas de maneira problemática. Inseparáveis, uma vez que a identidade para si é correlata ao Outro e a seu reconhecimento: nunca sei quem sou a não ser no olhar do Outro. Problemáticas, dado que "a experiência do outro nunca é vivida diretamente pelo eu... de modo que contamos com nossas comunicações para nos informarmos sobre a identidade que o outro nos atribui... e, portanto, para nos forjarmos uma identidade para nós mesmos”. (Dubar, 2005, p. 135).

Dessa forma, o autor coloca em evidência a importância da interação entre os sujeitos, pois se cada um é identificado pelo o Outro, também pode recusar essa identificação e se definir de outra forma. "É pela e na atividade com os outros, o que implica um sentido, um objetivo e/ou uma justificação, uma necessidade de, que um indivíduo é identificado e levado a endossar ou a recusar as identificações que recebe dos outros e das instituições.” (Dubar, 2005, p. 138).

Assim, colegas de trabalho, membros da Secretaria de Educação e do governo, os alunos e as famílias constituem o "outro" significativo a quem se tenta acomodar a identidade para si. De modo que cada um deles poderá ter influências diferentes no processo relacional de construção da identidade profissional do professor.

Para Dubar (2005), o sindicato representa uma importante instituição que contribui na construção da identidade profissional, tanto do ponto de vista da transação subjetiva, quanto da transação objetiva:

A persistência por toda a história industrial, do "fenômeno corporativista" (Segrestin, 1985) testemunha a que ponto a identidade de ofício, constitutiva das "comunidades pertinentes de ação coletiva" - principalmente sindical -, revelou-se capaz de resistir e de se reproduzir através de todas as formas de racionalização do trabalho e das empresas. E decerto por representar historicamente uma das formas de articulação mais sólidas entre a identidade para si - através do esquema da aprendizagem implicando a progressão aprendiz-companheiro-mestre (Ariès, 1973) e a transmissão de uma cultura de ofício através das gerações - e a identidade para o outro - através do modelo das relações profissionais fundadas na regulação conjunta das organizações patronais e sindicais (Reynaud, 1989) - que ela representa uma imbricação estável da transação subjetiva, o que permite um desenvolvimento autoconfirmado da identidade e da transação objetiva que fornece as confirmações reguladas desse desenvolvimento autônomo. (DUBAR, 2005 p. 283).

A instituição sindical contribuiria tanto para a construção de si, quanto para a construção do outro, ao transmitir determinada cultura profissional. 
Ao serem perguntados se a participação sindical interferia nas relações dentro da escola, 133 respondentes afirmaram que sim, 56 disseram que não e 24 não se pronunciaram:

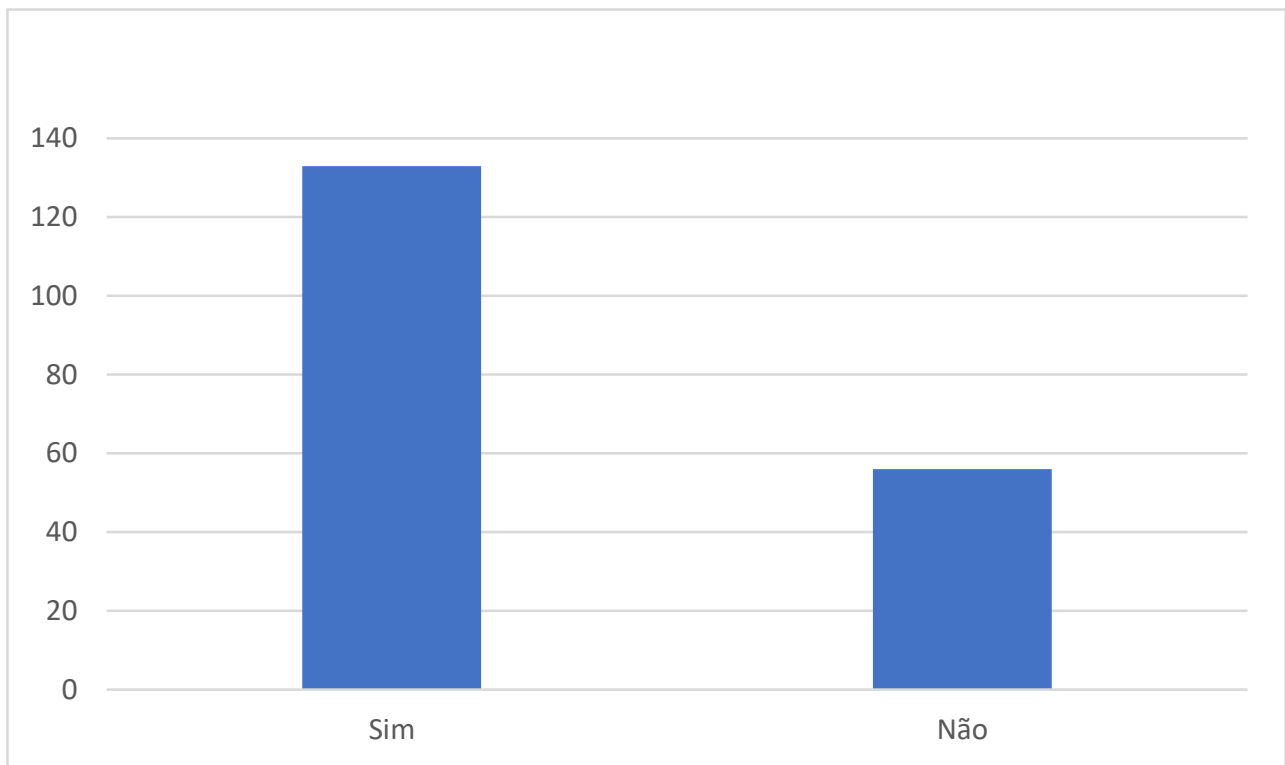

Gráfico 7 - Interferência da participação sindical nas relações estabelecidas na escola

Fonte: Elaboração própria.

Algumas das justificativas apresentadas às respostas sobre a influência das relações sindicais na escola demonstram a percepção dos respondentes sobre a visão que o outro constrói sobre si, sejam eles diretores, colegas professores ou alunos.

Entre as influências da militância na escola, é recorrente o sentimento de reconhecimento por parte dos colegas: "Todos da escola têm muito respeito pela luta que faço frente ao sindicato." Não raro, o militante, especialmente o representante de escola, torna-se uma referência: "Minhas opiniões, apesar de nem sempre apoiadas, são respeitadas e os colegas me procuram como suporte e conselheira." Porém também são comuns os conflitos: "Em alguns momentos, é um agregador, em outros, causa resistência.” A não adesão ao movimento sindical é a principal causa dessas desavenças: "Alguns colegas possuem dificuldade para entender a conjuntura política e quando são cobrados ficam com raiva. Como sou representante do Sepe isso ocorre sempre."

Muitos conflitos ocorrem também entre professores militantes e a direção das escolas, pois até 2015 as direções das escolas municipais de Duque de Caxias eram escolhidas por indicação política, assim, vários impasses ocorriam, principalmente no período de greve, quando diretores se posicionavam a favor do governo, 
inclusive perseguindo professores militantes. De acordo com alguns depoimentos, como: "As pessoas dizem que eu sou o Sepe na escola. A direção fica pouco confortável, mesmo a eleita", vê-se que ainda hoje, com o processo eleitoral, há alguns resquícios de uma relação conflituosa, em que o diretor pode ser visto como "opositor" e o militante como "um perigo": "Sou referência para as colegas de trabalho e um perigo para a direção da unidade escolar." Isso se dá, sobretudo, pelo aspecto questionador do professor militante e a liderança que costuma exercer sobre o grupo: "Muitas vezes sou o chato que incentiva greves. Ganho inimizades, às vezes, por conta dos posicionamentos."

Assim, vistos por alguns como "conselheiros" e por outros como "ameaça", há uma diversidade de papéis atribuídos aos professores atuantes no movimento sindical, que vão depender da sua trajetória de envolvimento, da posição que ocupam no espaço sindical e na escola, e das relações que estabelecem a partir desses "atos de atribuição" (que visam definir uma identidade para o outro) e dos "atos de pertencimento" (os que indicam que tipo de homem você quer ser, ou seja, a identidade para si) que adotam (DUBAR, 2005).

Apesar desses conflitos, a militância sindical é encarada, em geral, com positividade no que diz respeito ao exercício da docência e a apropriação dos espaços de discussão na escola. A experiência com a organização sindical "faz propor, de forma mais intensa, políticas para a escola"; "potencializa as discussões e forma politicamente"; "no caso dos professores, a interação aumenta em relação aos alunos e tem a ver com o estímulo à organização estudantil."”

Enfim, em maior ou menor medida, a participação sindical reverbera sobre as relações estabelecidas na escola e sobre a identidade do professor militante. 


\section{5 \\ Considerações finais}

Dentro do vasto e ainda não completamente explorado campo do associativismo docente, escolhi a experiência formativa no espaço sindical como objeto de estudo. Nesse capítulo final, tentarei fazer uma sistematização dos pontos abordados na tese, trazendo a síntese do que pude apreender ao longo da investigação sobre o sindicato docente como espaço de formação para o professor.

Antes, porém, não posso deixar de sinalizar que no decorrer da escrita desta tese aconteceram mudanças na conjuntura local e global que atingiram direta e indiretamente os sindicatos e, por conseguinte, meu campo de pesquisa. Em âmbito global, houve um avanço do conservadorismo, com levante de grupos extremistas, eleição de candidatos da direita e adoção de medidas contrárias aos direitos humanos. No Brasil, uma série de manobras antidemocráticas culminou no impeachment da Presidenta Dilma Rousseff, seguido de múltiplas reformas que propunham a retirada de direitos historicamente conquistados. No Estado do Rio de Janeiro, e mais especificamente em Duque de Caxias, cresceu o quantitativo de desempregados, sendo constantes os atrasos de salários dos servidores públicos e a tentativa de desmonte do plano de carreira dos profissionais da educação (Extra, 2017; Jornal do Brasil, 2017). Todos esses acontecimentos parecem convergir para um dilaceramento do estado democrático de direito.

A despeito dessa conjuntura pouco favorável ao sindicalismo, sindicatos e associações docentes permanecem atuando junto aos professores, ou mais amplamente à categoria dos profissionais da educação (Dal Rosso, 2011; Gindin, 2015; Oliveira \& Mello, 2014). No bojo dessas organizações, estão os atores que conduzem esse movimento, seja como direção ou como base, defendendo direitos adquiridos, buscando a valorização do professor, discutindo políticas educacionais, entre outras ações.

À medida que a tese era escrita, novos acontecimentos iam ocorrendo, sendo necessário, inclusive, fazer atualizações com notas, como por exemplo, sobre o plano de carreira da rede municipal de Duque de Caxias que passou por um forte ataque em agosto de 2017. Isso dá a dimensão do desafio que é escrever sobre o tema do sindicalismo docente em meio a um contexto de mudanças e profundos retrocessos. Se por um lado esse terreno movediço me trouxe certa insegurança, por 
outro, deu-me a certeza da importância de registrar essa passagem, no intuito de conservar a memória do movimento sindical, explicitando os caminhos de resistência adotados pelos professores e contribuindo com os próximos estudos sobre a organização e formação docente.

Nesse sentido, ao fazer um levantamento sobre as pesquisas a respeito do sindicalismo docente, percebi uma lacuna no que diz respeito a esse tipo de instituição na atualidade, assim como de pesquisas que abordem a experiência dos sujeitos na organização sindical e seu potencial formativo.

Deste modo, na tentativa de trazer à tona as experiências individuais dos participantes em articulação com a construção coletiva do movimento sindical (Vidal \& Vianna, 2010), ouvi a história de vida de 15 professores militantes e observei passo a passo a organização sindical docente na rede municipal de Duque de Caxias no período de julho de 2015 a julho de 2017. A escolha desse núcleo sindical foi feita não apenas por minha ligação pessoal com a entidade, mas também por sua reconhecida trajetória de lutas que se destaca entre os demais núcleos e regionais que compõe o Sindicato Estadual dos Profissionais da Educação do Rio de Janeiro.

Além das observações e entrevistas, foram aplicados questionários em assembleias no ano de 2016 sobre a atuação e formação dos participantes do movimento sindical. O intuito foi obter dados panorâmicos sobre a presença e nível de participação dos diferentes agentes que constituem o movimento sindical docente no município de Duque de Caxias.

No cruzamento dos dados obtidos por essas três entradas no campo (observações, entrevistas e questionários), pude notar a multiplicidade de sentidos que a experiência sindical pode assumir nas trajetórias dos sujeitos e busquei compreender o processo de formação e organização docente nesse município. Obviamente é difícil exprimir toda a complexidade das relações vivenciadas no âmbito sindical. O que trouxe aqui, portanto, foi uma seleção do que pareceu mais significativo após os estudos e análises teóricas e empíricas sobre a formação no espaço sindical.

Para escrita da tese, elegi como fio condutor as trajetórias de vida dos professores militantes que atuam no Sepe/Caxias, na certeza de que cada história tem sua singularidade e importância, porém optando por destacar as aproximações 
e similitudes encontradas entre elas, tendo como eixo a origem familiar e social, o ingresso no magistério e a experiência sindical.

Debruçar-me sobre a origem familiar e social foi fundamental para a compreensão das trajetórias de vida dos sujeitos. A partir dessa análise, ficou claro que os atores do movimento sindical em Duque de Caxias são oriundos de diferentes estratos das camadas populares e, portanto, estiveram sujeitos a limitações no campo educacional e escolha profissional. No curso de sua história, fizeram as escolhas dentro do que lhes foi possível desejar (Bourdieu, 2013; Nogueira, 2005) e foram ressignificando esses projetos mediante as oportunidades surgidas ao longo da vida (Velho, 1994). Para alguns deles, o ingresso no magistério não foi uma opção pessoal, no entanto, no contato com essa profissão, pressupostos foram sendo desmitificados e o interesse gerado.

No campo dos valores familiares, destacaram-se as relações de gênero sobretudo na fala de algumas mulheres - marcadas pelas desigualdades de educação entre os sexos, enquanto outras vivenciaram o oposto. Essas relações acompanham sua trajetória desde a infância até a militância sindical, quando levantam a bandeira da igualdade de direitos e do feminismo, lutando contra o machismo dentro do movimento sindical e na sociedade como um todo.

Discutindo as relações de gênero no âmbito sindical, Ferreira (2008, p. 22) menciona que certos valores culturais "interferem nas alternativas e na participação ou não, bem como no tipo de participação que as mulheres tenham na atividade sindical." Para a autora, "a falta de protagonismo feminino não ocorre apenas no meio sindical. Historicamente, nos espaços públicos, a presença masculina supera em muito a feminina, ficando as decisões políticas a cargo dos homens."

Embora tenham sido observadas relações desiguais entre homens e mulheres, como em praticamente todos os campos sociais na realidade brasileira, a condução do movimento sindical docente em Duque de Caxias é majoritariamente feminina e, diferente dos estudos trazidos pela autora sobre a falta de domínio das "tecnologias de poder" das mulheres em relação aos homens, no Sepe/Caxias há uma presença forte de lideranças femininas, tanto que priorizei a realização das entrevistas com militantes mulheres, em detrimento dos homens.

Alguns valores, como a dedicação ao estudo, também foram cultivados desde a tenra idade e outros, como a valorização da política, para a maioria dos entrevistados, foram sendo construídos ao longo da história pessoal, à medida que 
os sujeitos ingressavam em novos grupos sociais, como a igreja, o movimento estudantil, a associação de moradores e o sindicato. Esse movimento foi igualmente observado por Silva (2012) em sua pesquisa sobre lideranças sindicais na Baixada Fluminense.

Para o ingresso no movimento sindical docente, sobressaem alguns caminhos: as redes sociais, especialmente os grupos jovens e comunidades eclesiais de base de uma Igreja Católica mais progressista; uma vida pregressa de militância junto ao movimento estudantil, político partidário, ou associação de moradores; a formação para o magistério e o contato com professores e estudantes militantes; a entrada profissional em uma rede pública mobilizada, com presença de militantes nas escolas que introduziam os recém-chegados ao sindicalismo; a conjuntura de redemocratização dos anos de 1980 e 1990, que causava certa ânsia pela participação nos diferentes espaços de atuação na sociedade.

De modo geral, a experiência sindical desses sujeitos, assume um caráter formativo, pois à medida que militam, evocam experiências anteriores, constroem novos saberes e práticas, com alguns deles atuando em outros movimentos sociais e políticos.

Para alguns, a militância sindical se aproxima do que propõe Gramsci, ao falar do intelectual orgânico, pois "se envolvem com as organizações populares para construir uma democracia realmente 'orgânica' para todo o corpo social, não apenas para uma parte dele." (Semeraro, 2006, p. 385).

Para outros, a busca pelo sindicalismo está mais relacionada à formação de uma rede de proteção contra os ataques sofridos pelo magistério no campo das relações de trabalho: medidas governamentais injustas, imposições da chefia, indisposições com a comunidade escolar, entre outros. Também negociações salariais e progressão de benefícios. O sindicato é a quem recorrem para a defesa e ampliação de seus direitos.

Para o grupo de professores mais engajados, independente do contexto de "crise" o papel formativo do sindicato em relação aos seus membros é claro. No entanto, para aqueles que entendem o sindicato como entidade limitada à defesa coorporativa, a formação fica em segundo plano. E em momentos de difícil negociação, como o vivenciado nos últimos dois anos, em que a correlação de forças é desfavorável aos trabalhadores, a confiança na instituição sindical fica abalada. 
Essas visões diferenciadas de sindicato geram determinados conflitos em grupos divergentes em seu interior. As diferentes orientações de pensamento disputam o domínio na condução das ações sindicais.

$\mathrm{Na}$ fala dos militantes emergem memórias coletivas da instituição sindical da qual pertencem. São lembranças partilhadas entre gerações e que vão sendo cultivadas a cada encontro através de falas, fotos, cartazes. Membros mais antigos do movimento sindical tendem a valorizar mais a história de lutas e conquistas construídas ao longo dos anos no núcleo sindical de Duque de Caxias, enquanto grupos de recém-chegados em meio a um contexto de crise não têm a mesma compreensão dessa trajetória. Como coloca Pollak (1989), as memórias também são campos de disputa e, portanto, apresentam divergências, ênfases em determinados momentos e grupos, silenciamentos de outros.

Portanto, ao analisar a história dos indivíduos, tentei também trazer as histórias sobre a instituição, procurando entender o que faz do sindicato um espaço formativo para os professores.

Para responder a essa questão que guiou a pesquisa, elegi duas dimensões da formação no âmbito sindical como importantes de serem consideradas: a coletividade e a participação. Para compreender a atualidade de cada uma delas no campo da docência, é interessante pensar a coletividade em contraposição ao isolamento docente (Duarte, 2010) e participação em contraposição à passividade (Sarti, 2012).

O isolamento está no bojo da intensificação do trabalho docente. O professor, sobrecarregado de atividades que extrapolam os tempos e espaços do seu ofício, não tem tempo para a seu desenvolvimento profissional, planejamento reflexivo de suas aulas, nem tão pouco para interação com os seus colegas de trabalho. Em oposição, a pesquisa mostrou que o sindicato é um lugar propício ao diálogo e à partilha de experiências coletivas (Vidal \& Vianna, 2010), assim como para reivindicação da garantia desses espaços no ambiente escolar.

De acordo com Sarti (2012, p. 329), os professores são considerados como passivos no processo de profissionalização, "ocupando o lugar de consumidores de discursos e produtos que lhes são propostos para a formação continuada e/ou em serviço", cada vez mais estandardizada, não contemplando seus anseios. Diferente desse quadro, o sindicato tem potencial para o desenvolvimento de uma participação efetiva na formação, mediante o debruçar em questões da realidade 
que dão sentido ao processo formativo, valorização dos saberes da experiência e da capacidade intelectual do professor. Ao contrário da passividade, o movimento sindical requer de seus membros, a participação efetiva, supondo "uma ingerência nas relações de poder e na disputa pela distribuição dos recursos materiais e simbólicos.” (Stubrin, 2010, p. 1).

Nas observações realizadas durante a pesquisa, percebi dois tipos distintos de formação: um de caráter mais sistemático, com objetivos definidos em função de demandas da docência, vida funcional dos profissionais da educação ou até mesmo políticas educacionais. São exemplos dessas formações, as plenárias com segmentos específicos, como a educação infantil, educação especial, especialistas e jovens e adultos, para acúmulo de questões e respostas demandadas pelo governo ou pela própria categoria. $\mathrm{O}$ outro exemplo são as palestras, cursos e seminários oferecidos quase sempre com o apoio da academia, em especial a FEBF, mas também em conjunto com outras instituições e movimentos sociais, cuja finalidade é o aprofundamento de questões referentes ao cotidiano escolar, como por exemplo, as relações étnico-raciais, os programas governamentais, como o "Mais Educação" e a avaliação em larga escala.

O outro tipo de formação tem características menos rígidas, pois não é "programada", com intuito de aprofundamento ou aprimoramento do desenvolvimento profissional, embora possa contribuir com ele. É uma formação que se dá pela ação, pela participação na organização docente, através dos fóruns ordinários e extraordinários como assembleias, conselhos, atos e manifestações. O conselho de representantes de escolas e assembleias, por exemplo, são ambientes que propiciam o encontro, a partilha de angústias, a busca por soluções e articulação para a cobrança de melhores condições para o exercício da docência, por conseguinte, da aprendizagem da coletividade.

Além desses espaços, "a corrida às escolas", ou o chamado "comando de greve", em que um grupo de professores militantes visita as unidades junto com a direção do sindicato para buscar o diálogo, na tentativa de convencer o colega (ou a escola como um todo) que, imerso em seu isolamento não encontrará disposição para a greve, paralisação ou outras atividades mais combativas. Nesse diálogo, emergem circunstâncias de opressão vivenciadas no cotidiano da escola, medo, angústia e alienação que paralisam o professor e dificultam a luta pelos seus 
direitos, fazendo-o submeter-se a condições insalubres de trabalho que vão desde a falta de material até a precariedade total da estrutura escolar.

Em 2017, o desconto de 24 dias de greve, somado ao atraso dos salários, foi um fator paralisante de ações mais combativas como a greve. A rede municipal, que nunca tinha convivido com os descontos - até então, sempre houve o pagamento mediante a negociação de reposição dos dias parados -, vivenciou o medo da retaliação, amargando a perda de quase um mês de salário, além do atraso dos demais proventos, retirada de gratificações e falta do repasse sindical.

Essa convergência de políticas de desmobilização gerou um conflito no movimento sindical do município, pois a ausência dos recursos básicos para a subsistência da família, para o deslocamento para as escolas e motivação para o trabalho era ao mesmo tempo a razão para a revolta, que poderia impulsionar ações mais contundentes e a estagnação, visto que a falta de dinheiro e o medo inviabilizam a própria movimentação sindical.

Com uma história de quase 40 anos de vitórias, o Sepe/Caxias passa por um momento difícil, porém não de desistência. Existe a certeza de que, como outras instituições, é preciso resistir (Melo, 2010). A dúvida é sobre “como resistir” diante de desafios que vêm sendo postos a cada dia. As perspectivas são de necessidade de busca por novos caminhos de luta, tendo em vista a transformação da conjuntura. Para isso, será necessário um esforço do sindicato docente na formação para a resistência. Infelizmente não há currículo pré-definido para tanto, cabendo ao movimento reinventar-se a cada dia. 


\section{6 \\ Referências bibliográficas}

ALCÂNTARA, Guilherme. Uma escola da ou para a periferia?: a produção das qualidades e dos direitos à educação em uma escola de Duque de Caxias. 2016. Tese (Doutorado em Educação) - Pontifícia Universidade Católica do Rio de Janeiro, Rio de Janeiro, 2016.

ALVARADO-PRADA, Luiz Eduardo; FREITAS, Thaís Campos; FREITAS, Cinara Aline. Formação continuada de professores: alguns conceitos, interesses, necessidades e propostas. Rev. Diálogo Educ., Curitiba, v. 10, n. 30, p. 367-387, maio/ago. 2010.

ALVES, José Claudio. Dos barões ao extermínio: uma história de violência na Baixada Fluminense. Rio de Janeiro: APPH-Clio, 2003.

ANDRADE, Dalila. Regulação educativa na América Latina: repercussões sobre a identidade dos trabalhadores docentes. Educação em Revista, Belo Horizonte, v. 44, p. 209-227, dez. 2006.

ARIÈS, Philippe. História social da criança e da família. Rio de Janeiro: LTC, 2012.

BAUER, Carlos et al. Sindicalismo e associativismo dos trabalhadores em educação no Brasil. Jundiaí: Paco Editorial, 2017. v. 3.

BOSI, Ecléa. Memória e sociedade: lembranças de velhos. São Paulo: Companhia das Letras, 1994.

. O tempo vivo da memória: ensaios de psicologia social. São Paulo: Ateliê editorial, 2003.

BOURDIEU, Pierre. Coisas ditas. São Paulo: Brasiliense, 2004.

Razões práticas: sobre a teoria da ação. Campinas: Papirus, 2013

; PASSERON, Jean-Claude. Os herdeiros: os estudantes e a cultura. Florianópolis: Ed. UFSC, 2014.

BRANDÃO, Zaia. Operando com conceitos: com e para além de Bourdieu. Educação e Pesquisa, São Paulo, v. 36, n. 1, p. 227-241, jan./abr. 2010.

BRAZ, Antônio Augusto; ALMEIDA, Tânia Maria Amaro. De Merity a Duque de Caxias: encontro com a história da cidade. Duque de Caixas: APPH-Clio, 2010. 
BRAZ, Antônio Augusto. Histórico: "Na FEUDUC trabalhadores formam trabalhadores". Publicado em fev. 2013. Disponível em: <http://capfeuduc.com.br/historia/>. Acesso em: 2 jun. 2017.

CANDAU, Vera Maria. Rumo a uma nova didática. Petrópolis: Vozes, 2013.

CARVALHO, Maria Eulina P. Entre a escola e a família: a instituição informal do reforço escolar. In: NOGUEIRA, Maria Alice; ROMANELLI, Geraldo; ZAGO, Nadir (Org.). Família e escola: novas perspectivas de análise. Petrópolis: 2013.

DAL ROSSO, Sadi. Associativismo e sindicalismo em educação: organização e lutas. Brasília: Paraleo 15, 2011.

Fragmentação sindical. Educar em Revista, Curitiba, n. 48, p. 39-52, abr./jun. 2013.

DAVID, Fátima Bitencourt. Histórias de professoras: práticas, alternativas e disputas políticas em Duque de Caxias. 2004. Dissertação (Mestrado em Educação) - Universidade Estadual do Rio de Janeiro, Rio de Janeiro, 2004.

DEMAILLY, Lise. Crise, rèagencementes identitaires et deprofissionalisation dans les métiers de l'education. Recherche \& Formation, n. 74, p. 115-126, 2013.

DUARTE, A. M. C. Intensificação do trabalho docente. In: OLIVEIRA, D. A.; DUARTE, A. M. C.; VIEIRA, L. M. F. Dicionário: trabalho, profissão e condição docente. Belo Horizonte: UFMG/Faculdade de Educação, 2010. 1 CD-ROM.

DUBAR, Claude. A socialização: construção das identidades sociais e profissionais. São Paulo: Martins Fontes, 2005.

DUQUE DE CAXIAS. Lei ${ }^{\circ} 2.713$, de 30 de junho de 2015. Aprova a adequação do Plano Municipal de Educação ao Plano Nacional de Educação... In: Boletim Oficial, Duque de Caxias, 30 jun. 2015. Disponível em: <http://www.mprj.mp.br/documents/20184/174657/duque_de_caxias_lei_2.713_1 5_plano_municipal_de_educacao.pdf >. Acesso em: 10 jun. 2017.

EXTRA. Notícias. Trabalhadores de Duque de Caxias sofrem com o aumento do desemprego. Rio de Janeiro, 28 maio 2017.

FERREIRA, Márcia Ondina Vieira. Notas sobre as relações entre identidade e sindicalismo docentes. Educação \& Sociedade, v. 28, n. 99, p. 377-399, 2007.

Somos todos trabalhadores em Educação?: reflexões sobre identidades docentes desde a perspectiva de sindicalistas. Educação e Pesquisa, São Paulo, v. 32, n. 2, p. 225-240, maio/ago. 2006. 
FERREIRA, Márcia Ondina Vieira. Desconforto e invisibilidade: representações sobre relações de gênero entre sindicalistas docentes. Educação em Revista, Belo Horizonte, n. 47, p. 15-40, jun. 2008.

FERREIRA, Márcia Ondina Vieira. "Discutir educação é discutir trabalho docente": o trabalho docente segundo dirigentes da Confederación de Trabajadores de la Educación de la República Argentina (CTERA). Revista Brasileira de Educação, v. 14, n. 41, maio/ago. 2009.

GATTI, Bernadete Angelina; BARRETO, Elba Siqueira de Sá. Professores do Brasil: impasses e desafios. Brasília: UNESCO, 2009.

GINDIN, Julián. Por nós mesmos: o sindicalismo docente de base na Argentina, no Brasil e no México. Rio de Janeiro: Azougue, 2015.

GOHN, Maria da Gloria. Movimentos sociais e educação. 8. ed. São Paulo: Cortez, 2012a.

Teorias dos movimentos sociais: paradigmas clássicos e contemporâneos. São Paulo: Edições Loyola, 2012b.

GUEDES, Simoni Lahud; LIMA, Michelle da Silva. Casa, família nuclear e redes sociais em bairros de trabalhadores. In: BARROS, Myriam Lins de Barros. Família e gerações. Rio de Janeiro: FGV, 2006.

HALBWACHS, Maurice. A memória coletiva. São Paulo: Vértice Editora; Revista dos Tribunais, 1990.

JORNAL DO BRASIL. Com redução salarial e pagamentos atrasados, professores de Caxias protestam. Rio de Janeiro, 7 ago. 2017.

KAUFMANN, Jean-Claude. A entrevista compreensiva: um guia para pesquisa de campo. Petrópolis: Vozes; Maceió: Edufal, 2013.

LAGO, Luciana Corrêa do. A "periferia" metropolitana como lugar do trabalho: da cidade-dormitório à cidade plena. Cadernos Ippur, n. 2, ago./dez. 2007.

LAHIRE, Bernard. Sucesso escolar nos meios populares: as razões do improvável. São Paulo: Editora Ática, 2004.

LANTHEAUME, Françoise. Professores e dificuldade do ofício: preservação e reconstrução da dignidade profissional. Cadernos de Pesquisa, v. 42, n.146, p. 368-387, maio/ago. 2012.

LAZARONI, Zilda. Mate com Angu: a história de Armanda Álvaro Alberto. São Paulo: Editora Europa, 2010. 
LELIS, Isabel. A. A polissemia do magistério: entre mitos e histórias. 1996. Tese (Doutorado) - Pontifícia Universidade Católica do Rio de Janeiro, 1996.

; XAVIER, Libânia Nacif. O ofício docente na voz de suas lideranças sindicais. In: ; NASCIMENTO, M. G. O trabalho docente no século XXI: quais perspectivas? Rio de Janeiro: Forma e Ação, 2009.

; NASCIMENTO, Maria da Graça. O recurso às histórias de vida para o estudo de trajetórias profissionais. In: MARCONDES, M. I.; TEIXEIRA, E.; OLIVEIRA, I. A. Metodologias e técnicas de pesquisa em educação. Belém: Eduepa, 2010.

O trabalho docente na escola de massa: desafios e perspectivas. Sociologias, Porto Alegre, n. 29, p. 152-174, jan./abr. 2012.

LUDKE, Menga; BOING, Alberto Luiz. Caminhos da profissão e da profissionalidade docentes. Educação e Sociedade, Campinas, v. 25, n. 89, p. 1159-1180, set./dez. 2004.

MELO, S. D. G. Resistência docente. In: OLIVEIRA, D. A.; DUARTE, A. M. C.; VIEIRA, L. M. F. Dicionário: trabalho, profissão e condição docente. Belo Horizonte: UFMG/Faculdade de Educação, 2010. 1 CD-ROM.

MIRANDA, Kênia. Como os trabalhadores da educação pensam a educação dos trabalhadores: um estudo sobre os sindicatos docentes do Rio de Janeiro. In: DAL ROSSO, Sadi. Associativismo e sindicalismo em educação: organização e lutas. Brasília: Paraleo 15, 2011.

NOGUEIRA, Claudio Marques Martins. Limites da explicação em sociologia da educação: considerações a partir de pesquisas sobre o processo de escolha do curso superior. In: CONGRESSO BRASILEIRO DE SOCIOLOGIA. 12., 2005, Belo Horizonte. Anais... Belo Horizonte, 2005.

NOGUEIRA, Maria Alice. Relação família-escola: um novo objeto na sociologia da educação. Paideia, Ribeirão Preto, FFCLRP-USP, fev./ago. 1998.

OLIVEIRA, Dalila Andrade; MELLO, Savana Diniz Gomes. Sindicalismo docente: desafios e perspectivas. Grupo de Estudos sobre Políticas Educacionais e Trabalho Docente, Sindicato dos Trabalhadores em Educação de Pernambuco. Camaragibe, PE: CCS Gráfica e Editora, 2014.

PEIXOTO, Clarice. As transformações familiares e o olhar do sociólogo. In: SINGLY, F. Sociologia da família contemporânea. Rio de Janeiro: Editora FGV, 2007. 
PEIXOTO, Clarisse Ehlers; LUZ, Gleice Mattos. De uma morada à outra: processos de re-coabitação entre as gerações. Cadernos PAGU, n. 29, p. 171-191, jul./dez. 2007.

PEREIRA, Júlio Emílio Diniz. Formação continuada de professores. In: OLIVEIRA, Dalila Andrade; DUARTE, Adriana Canela; VIEIRA, Lígia Fraga. Dicionário: trabalho, profissão e condição docente. Belo Horizonte: UFMG/Faculdade de Educação, 2010. 1 CD-ROM.

PHILIPIS, Denis Charles; BURBULES, Nicholas. Can, and Sould, Educational Inquiry Be Scientific? Postpositivismo and Educational Reserch. [s.: 1.]: Litt Lefield Publishes, 2000.

PINTO, Céli Regina Jardim. Feminismo, história e poder. Rev. Sociol. Polít., Curitiba, v. 18, n. 36, p. 15-23, jun. 2010.

POLLAK, Michael. Memória, esquecimento, silêncio. Estudos históricos, Rio de Janeiro, v. 2, n. 3, p. 3-15, 1989.

PORTES, Écio Antônio. O trabalho escolar das famílias populares. In: NOGUEIRA, Maria Alice; ROMANELLI, Geraldo; ZAGO, Nadir (Org.). Família escola: trajetórias de escolarização em camadas médias e populares. Petrópolis: Vozes, 2000.

REIS, Kellen Cristina F; MAIA, Ana Claudia B. Estereótipos sexuais e a educação sexista no discurso de mães. In: VALLE, T. G. M. (Org.). Aprendizagem e desenvolvimento humano: avaliações e intervenções. São Paulo: Cultura Acadêmica, 2009.

RESENDE, Tânia Resende. Pela "janela" do dever de casa, o que se vê das relações ente escolas e família? In: NOGUEIRA, Maria Alice; ROMANELLI, Geraldo; ZAGO, Nadir (Org.). Família e escola: novas perspectivas de análise. Petrópolis: 2013.

SARTI, Flavia Medeiros. O triângulo da formação docente: seus jogadores e configurações. Educação e Pesquisa, São Paulo, v. 38, n. 2, p. 323-338, abr./jun. 2012.

SAWICKI, Frédéric; SIMÉANT, Johanna. Inventário da sociologia do engajamento militante: nota crítica sobre algumas tendências recentes dos trabalhos franceses. Sociologias, Porto Alegre, n. 28, p. 200-255, set./dez. 2011.

SEMERARO, Giovanni. Intelectuais “orgânicos” em tempos de pós-modernidade. Cad. Cedes, Campinas, v. 26, n. 70, p. 373-391, set./dez. 2006. 
SETTON, Maria da Graça. Família, escola e mídia: um campo com novas configurações. Educação e Pesquisa, São Paulo, v. 28, n. 1, p. 107-116, jan./jun. 2002.

SILVA, Andréa Cristina Oliveira Duarte de Souza S. da. Caminhos do sindicalismo: trajetória de vida de professores do SEPE/Baixada Fluminense. 2012. Dissertação (Mestrado em Educação) - Universidade Federal do Rio de Janeiro, 2012.

SILVA, Marilda. Habitus professoral e habitus estudantil: uma proposição acerca da formação de professores. Educação em Revista, Belo Horizonte, v. 27, n. 3, p. 335-359, dez. 2011.

SIMÕES, Nádia de Aquino. Fundef e movimento sindical docente: a experiência de Duque de Caxias/RJ. 2000. Dissertação (Mestrado em Educação) - Universidade Federal Fluminense, Niterói, 2000.

SINDICATO ESTADUAL DE EDUCAÇÃO DOS PROFISSIONAIS DO RIO DE JANEIRO (SEPE/RJ). Site oficial. Disponível em: <http://seperj.org.br/> . Acesso em: 28 dez. 2015.

SINGLY, F. Sociologia da família contemporânea. Rio de Janeiro: Editora FGV, 2007.

SOBREIRA, Henrique Garcia. Alguns aspectos da reorganização do movimento dos professores públicos do Estado do Rio de Janeiro (1977-1980) Educação e Sociedade, v. 22, n. 77, p. 131-160, dez. 2001.

SOUZA, J. Uma nova classe trabalhadora brasileira? In: Os batalhadores brasileiros: a nova classe média ou nova classe trabalhadora. Belo Horizonte: UFMG, 2010 .

SOUZA, J.; BERG, T. O batalhador e sua família. In: Os batalhadores brasileiros: a nova classe média ou nova classe trabalhadora. Belo Horizonte: UFMG, 2010 .

SOUZA, Marlucia Santos de. Escavando o passado da cidade: história política da cidade de Duque de Caxias. Duque de Caxias: APPH-Clio, 2014.

STUBRIN, F. Participação social. In: OLIVEIRA, D. A.; DUARTE, A. M. C.; VIEIRA, L. M. F. Dicionário: trabalho, profissão e condição docente. Belo Horizonte: UFMG/Faculdade de Educação, 2010. 1 CD-ROM.

TARDIF, Maurice. A profissionalização do ensino passados trinta anos: dois passos para a frente, três para trás. Educação e Sociedade, Campinas, v. 34, n. 123, p. 551-571, abr./jun. 2013. 
TARDIF, Maurice; LESSARD, Claude. O ofício de professor: história, perspectiva e desafios internacionais. Petrópolis: Vozes, 2008.

O trabalho docente: elementos para uma teoria da docência como profissão de interações humanas. Petrópolis: Vozes, 2014.

THIN, Daniel. Para uma análise das relações entre famílias populares e escola: confrontação entre lógicas socializadoras. Revista Brasileira de Educação, v. 11 n. 32, maio/ago. 2006.

TUÃO, Renata Spadetti. Educação patrimonial em debate: movimentos de consolidação de um centro de memória da educação no município de Duque de Caxias. In: OLIVEIRA, Elaina F. R.; CARREIRO, Heloísa J. S. Seminário Vozes da Educação 20 anos: memórias políticas e formação docente. São Gonçalo: FEBF/Uerj, 2016.

TURA, Maria de Lourdes Rangel. A observação do cotidiano escolar. In: ZAGO, Nadir; CARVALHO, Marília Pinto; VILELA, Rita Amélia Teixeira (Org.). Itinerários de pesquisa: perspectivas qualitativas em sociologia da educação. 2 . ed. Rio de Janeiro: Lamparina, 2011.

UNIVERSIDADE DO ESTADO DO RIO DE JANEIRO (Uerj). Faculdade de Educação da Baixada Fluminense (FEBF). Site oficial. Disponível em: <http://www.febf.uerj.br/>. Acesso em: 29 maio 2017.

VAN ZANTEN, Agnès. Comprender y hacerse comprender: como reforzar la legitimidad interna y externa de los estudios cualitativos. Educação e Pesquisa, São Paulo, v. 30, n. 2, p. 301-313, maio/ago. 2004a.

VAN ZANTEN, Agnès. Pesquisa qualitativa em educação: pertinência, validez e generalização. Perspectiva, Florianópolis, v. 22, n. 1, p. 25-45, jan./jun. 2004b.

VELHO, Gilberto. Observando o familiar. In: NUNES, Edson de Oliveira. A aventura sociológica. Rio de Janeiro: Zahar, 1978.

. O antropólogo pesquisando em sua cidade: Sobre conhecimento e heresia. In: __ O desafio da cidade: novas perspectivas da antropologia brasileira. Rio de Janeiro: Campus, 1980.

. Memória, identidade e projeto. In: VELHO, Gilberto. Projeto e metamorfose. Rio de Janeiro: Jorge Zahar, 1994.

VIANNA, Cláudia. Os nós do "nós": crise e perspectivas da ação coletiva docente em São Paulo: Xamã, 1999.

A produção acadêmica sobre organização docente: Ação coletiva e relações de gênero. Educação e Sociedade, n. 77, p. 100-130, dez. 2001. 
VICENTINI, Paula Perin; LUGLI, Rosário Genta. História da profissão docente no Brasil: representações em disputa. São Paulo: Cortez, 2009.

VIDAL, D. G.; VIANNA, C. Experiência coletiva docente. In: OLIVEIRA, D. A.; DUARTE, A. M. C.; VIEIRA, L. M. F. Dicionário: trabalho, profissão e condição docente. Belo Horizonte: UFMG/Faculdade de Educação, 2010. 1 CD-ROM

XAVIER, Libânia Nacif. Profissão docente: entre a funcionarização e o associativismo (RJ 1920/1960). In: CONGRESSO BRASILEIRO DE HISTÓRIA DA EDUCAÇÃO. 4., 2006, Goiânia. Anais... Goiânia, 2006.

; SALOMÃO, Bluma. A importância do curso de pós-graduação SEPE/UFF para o projeto político do sindicato. In: SEMINÁRIO INTERNACIONAL DA REDE DE PESQUISADORES SOBRE ASSOCIATIVISMO E SINDICALISMO DOS TRABALHADORES EM EDUCAÇÃO. 2010. Anais... Associações e Sindicatos de Trabalhadores em Educação Rio de Janeiro, 2010.

Associativismo docente e construção democrática. Rio de Janeiro: EdUerj, 2013. 
Anexos

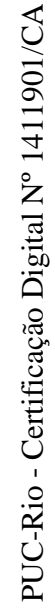




\section{Anexo A}

Distritos do município de Duque de Caxias

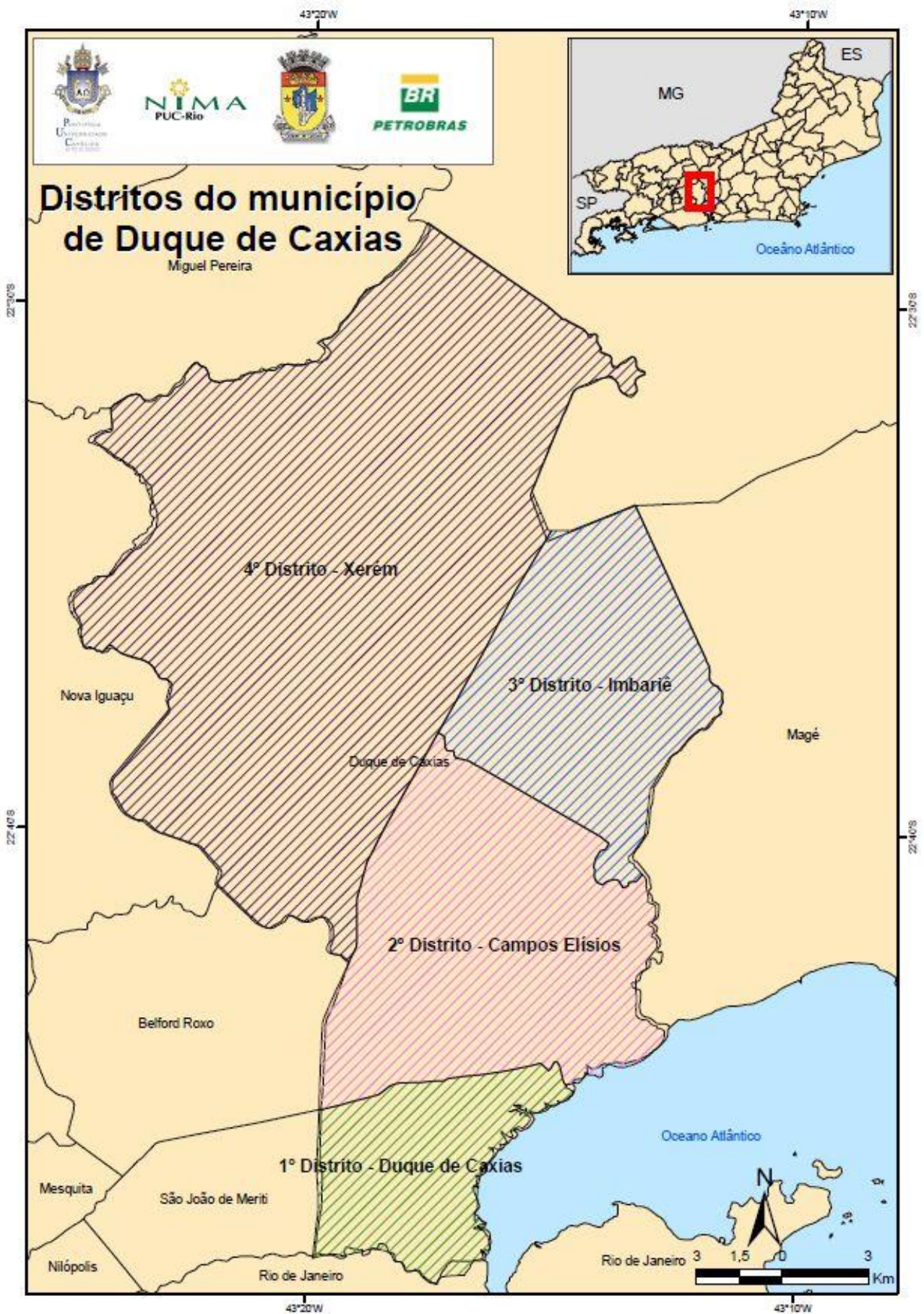

Fonte: CIDE; 2002, IBGE; 2000, PDBG; 2000, PDMC - Plano Diretor, 2006.

Produzido por Lab-Gis-PUC-Rio; 2009

Mapa disponível em:

<https://web.archive.org/web/20160303205057/http://www.nima.puc-

rio.br/sobre_nima/projetos/caxias/mapas_novos/Distritos_do_Municipio_de_Duq ue_de_Caxias.pdf >. Acesso em: 15 jan. 2018. 


\section{Anexo B}

Ficha de filiação ao sindicato

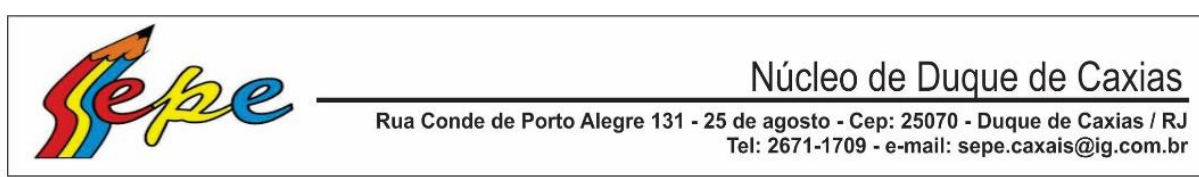

FICHA DE FILIAÇÃO

SINDICATO ESTADUAL DOS PROFISSIONAIS DA EDUCAÇÃO

NÚCLEO DE DUQUE DE CAXIAS

Nome:

Endereço:

Bairro: Cep:

Tel resd:

E-mail:

Data de nascimento: Estadi civil: Identidade: Órgão expedidor:

Matrícula:

Local de trabalho:

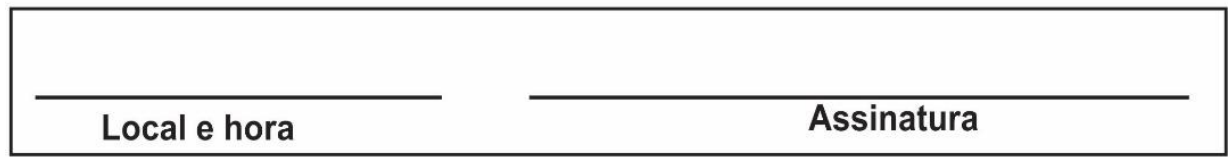

\begin{tabular}{|l|} 
Eu, AUTORIZAÇÃo \\
Matrícula__uncionário da PMDC \\
salário bruto, de acordo com o Estatuto, em favor do SINDICATO \\
ESTADUAL DOS PROFISSIONAIS DA EDUCAÇÃO NÚCLEO DE \\
DUQUE DE CAXIAS, da qual sou filiado. \\
Duque de caxias, _ de de \\
\hline ASSINATURA
\end{tabular}


Anexo C

Organograma

\title{
ORGANOGRAMA DO SEPE
}

\author{
CONGRESSO ESTADUAL
}

CONFERÊNCIA ESTADUAL

ASSEMBLÉIA GERAL

CONSELHO DELIBERATIVO

$50 \%$ dos membros

da Diretoria Estadual

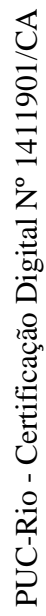

\section{Coordenaçäo \\ Coordenaçāo} Geral da Capital
Três membros de cada diretoria municipal e regional da capital

Diretoria dos

Núcleos Municipais e

Regionais da Capital

DIRETORIA ESTADUAL
Conselheiros de base eleitos nos núcleos municipais $\mathrm{e}$ regionais da capital

Cons. de Repres. Das Escolas

Representantes do Sepe nas Escolas
Coordenaçäo do Grande Rio
Coordenaçäo do Interior

Sec. Func. Adm. Depto. de Saúde

Sec. Assuntos Juridicos e Func

Sec. Imprensa e Comunicaçăo

Secretaria de Organizaçăo
Secretaria de Aposentados 
Apêndices

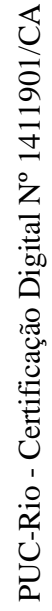




\section{Apêndice A}

\section{Questionário}

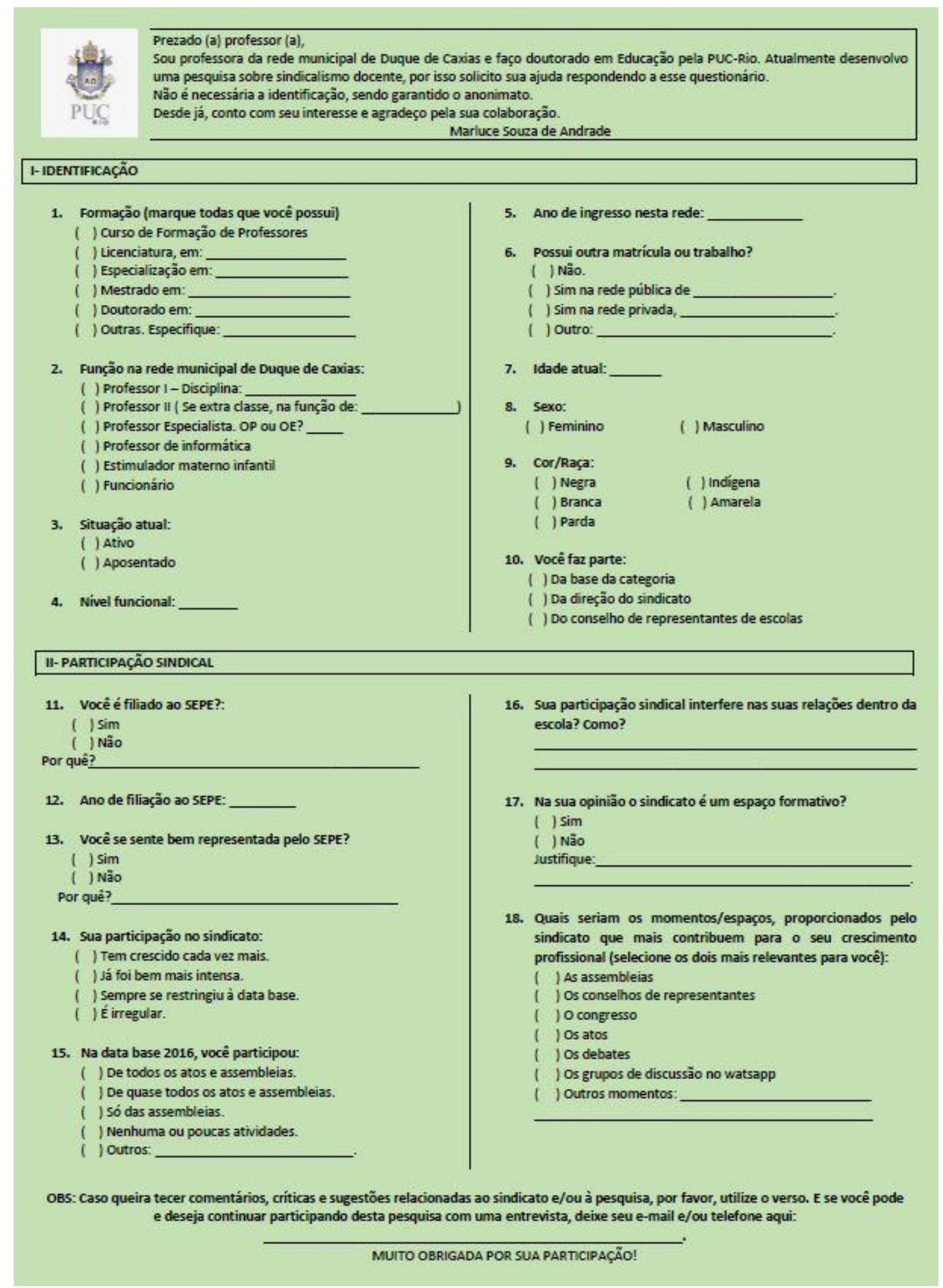




\section{Apêndice B}

\section{Guia de questões para a entrevista}

\section{Sobre você}

Eu queria que você começasse falando um pouco da sua família de origem (naturalidade, ocupação, escolaridade dos pais).

Seus pais são (ou eram) politizados?

$>$ Você participa ou participou de algum outro movimento social que marcou sua trajetória?

$>$ Seu engajamento foi influenciado de alguma forma por alguém ou algum fato marcante em sua vida?

\section{Trajetória de formação}

$>$ Como se deu sua chegada ao magistério?

$>$ Conta um pouco da sua trajetória de formação até aqui. Qual é sua formação? Onde se deu essa formação? (Escola pública ou privada) Leituras que te influenciaram ou te influenciam.

\section{Atuação profisssional}

Onde iniciou o exercício do magistério?

Passou por outras profissões?

$>$ Quais foram as dificuldades encontradas ao longo da carreira?

Fale um pouco de sua atuação profissional hoje. Como é a sua prática?

\section{Trajetória sindical}

Quando se deu a filiação no sindicato e por quais motivações?

$>$ Conte um pouco do início de sua trajetória sindical. Desde então, o que mudou?

> Qual é a importância do sindicato na sua trajetória pessoal e profissional?

> Como você avalia a sua participação no sindicato hoje? Como você descreveria sua atuação?

$>$ Como são suas relações com os colegas dentro do núcleo?

$>$ Como é visto pela categoria hoje? 
Quais as contribuições ou influências dessa sua trajetória sindical sobre a realização do teu trabalho na escola hoje?

\section{Sobre o Sindicato de Duque de Caxias}

Como vê o movimento sindical docente em Duque de Caxias hoje?

$>$ Você já esteve em outras redes? Qual é a diferença entre o movimento sindical de Caxias e de outras redes?

> Para você, qual é o nível de engajamento político da rede hoje?

> Há espaços de formação política e pedagógica dentro do sindicato?

$>$ Você percebe influências desses espaços na prática pedagógica da rede?

O que poderia ser melhor em relação ao sindicato?

$>$ Qual é a responsabilidade do sindicato com a formação do professor?

Como ele pode contribuir?

\section{Seus planos para o futuro}

OBS: Esse conjunto de perguntas foi elaborado e aprimorado ao longo das entrevistas como um auxílio para que os principais temas da pesquisa fossem abordados no diálogo com os participantes. No entanto, ele não representa uma grade rígida de questões a serem levantadas. Procurei explicar os objetivos da pesquisa no início da entrevista e a partir desse esclarecimento inicial, muitas questões foram abordadas pelos entrevistados no relato de sua trajetória sem a necessidade da leitura das perguntas desse guia. 


\section{Apêndice C}

Croqui da sede

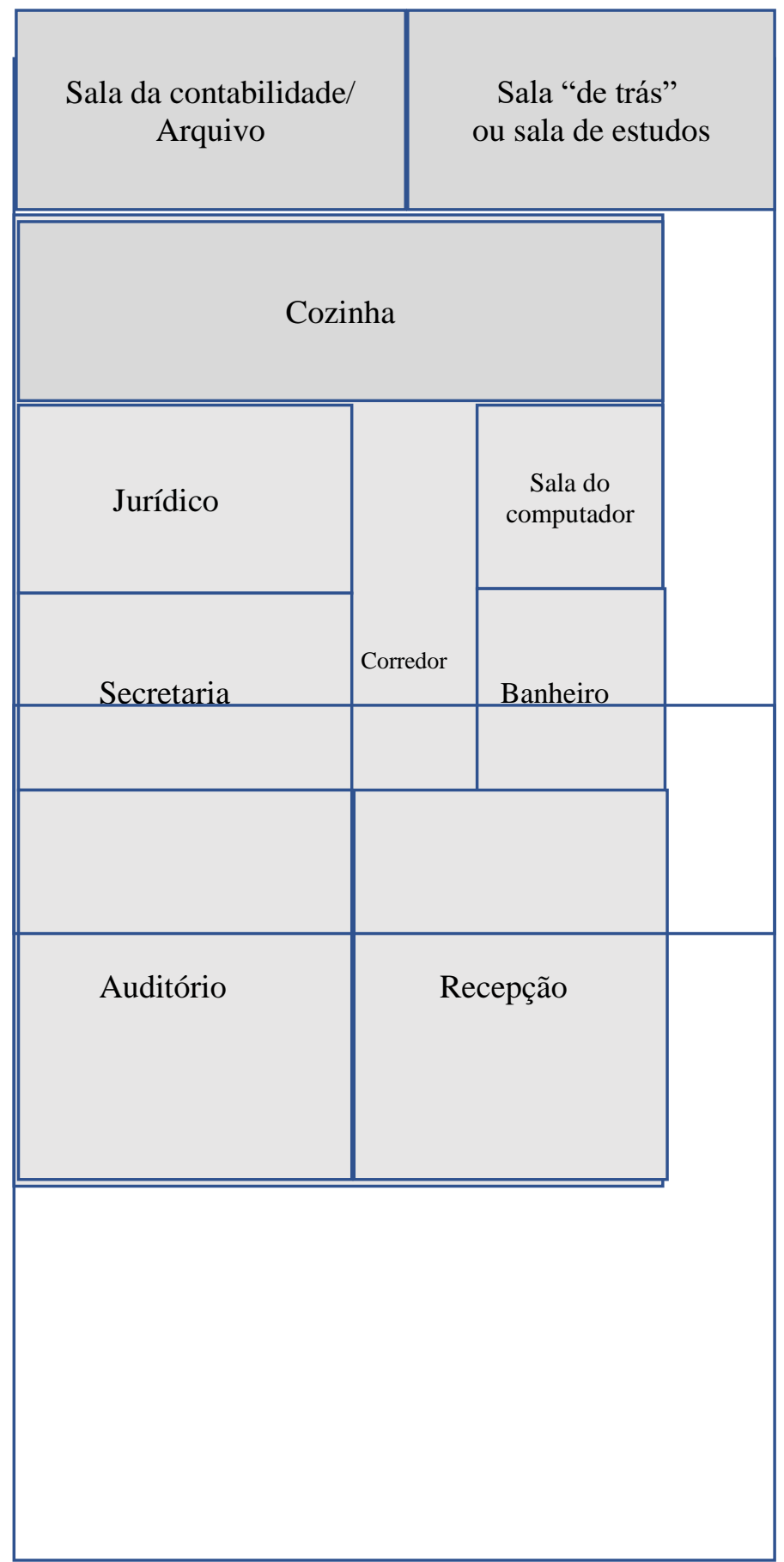




\section{Apêndice D}

\section{Entrevista com a professora Zilda, ex-diretora do SEPE}

M: Primeiramente eu queria que você falasse um pouquinho de você. Me fala sobre a sua origem...

Z: Bom. Eu sou... meu nome é Zilda Ester. Eu tenho 54 anos, acabei de fazer.

M: Parabéns.

Z: É... A minha formação, a minha graduação é em Pedagogia, com mestrado em Educação. Fiz Pedagogia na Uerj e o mestrado em Educação na UFRJ. É... Minha origem, eu diria, que a minha origem é uma origem de classe popular. Meu pai e minha mãe vieram do interior de Campos morar no Rio de Janeiro. É... os dois muito novos. Ele se não me engano, por conta do exército ou pra servir o exército e ela, 13 anos, a irmã casou, veio morar no Rio, pra ajudar a irmã, essas coisas, assim. É... então, um pouco a origem é um pouco essa. Tanto, que da minha família, eu sou a primeira pessoa, que acessa a universidade, isso tem...

M: Um peso...

Z: Tem um significado na história familiar. É... Acho, que é um pouco isso e criando a educação, acho que vai construindo mais a identidade profissional, eu acho, que a gente faz vestibular muito cedo, né? Eu entrei na Uerj com 17 anos.

M: Nossa.

Z: Então, eu lembro, que na época de vestibular, eu só via muito o que eu não queria.

M: (Risos).

Z: Mas, o que eu queria, eu não sabia muito. A Pedagogia foi meio, que uma aposta no escuro, que deu certo.

M: Hum hum.

$\mathrm{Z}$ : Eu me apaixono pelo curso logo no início do curso.

M: Hum hum.

Z: E sou apaixonada até hoje por essa área. Mas, quem me falou do curso foi um professor de literatura do $3^{\circ}$ ano.

M: Você estudava onde?

Z: Eu estudava no Lemos de Castro em Madureira. E ele me fala do curso de Pedagogia e aí, eu resolvo, mas, na verdade, eu não venho... eu não fiz normal, não tinha nenhuma origem... da trajetória, que uma parte das pessoas...

M: Não tinha nenhum professor na família?

Z: Não tinha nenhum professor na família, desde a infância, eu brincava de ser professora, isso é verdade, riscava as paredes, mas, acho, que toda criança tem uma fase, que brinca de ser professora, né?

M: Hum hum.

Z: Então, tinha um pouco essa brincadeira assim. Tem uma história que o... que Zilda, meu nome é Zilda Ester, Ester foi a minha mãe, que escolheu e Zilda foi meu pai, né? E tem essa história um pouco, que acho que... Zilda era o nome de uma professora dele de Geografia.

M: (Risos).

Z: Bom, tem várias versões, mas, uma das versões, que eu me lembro, que me contaram, foi essa, que Zilda era o nome da professora de Geografia e cargas d'água me marcou, não sei. Mas, a origem é um pouco essa. Então, assim, a faculdade é um momento importante da minha formação.

M: Hum hum.

Z: Tanto pessoal, que eu acho, que os caminhos profissionais também transformam minha vida, né? De várias formas. É... como, é... a identidade profissional porque eu criei uma paixão muito forte pelo curso de Educação. Me apaixono muito pela área.

M: É Uerj Caxias ou Maracanã? 


\section{Z: Uerj Maracanã.}

M: Hum hum.

Z: Uerj Maracanã. Então, essa... acho, que a origem é um pouco essa. E assim, eu termino o curso em 84,80 e... começo em 81, termino em 84 e 85 , início de 85 , tem um grande concurso, né? Governo Brizola, foi o concurso massivo, para área de Educação e... e por não feito o normal, estar fazendo Pedagogia... Naquela época, você para fazer orientação educacional, supervisão, administração, tinha a história de ter que ter experiência comprovada em magistério. Eu não tinha, como ter experiência em magistério, eu não tinha essa... essa comprovação. Eu opto por educação especial. Então, a minha habilitação no curso de Pedagogia, na época, foi em educação especial. E aí, o concurso abre com vagas, as vagas para educação especial são mais restritas, né?

\section{M: Hum hum.}

Z: Sempre um número restrito de vagas, mas, e o concurso já regionalizado. Então, passa a ser um concurso para o estado, você tem, que optar porque região, se você vai concorrer para Duque de Caxias, se vai concorrer pra Niterói, se vai concorrer para capital. E uma das coisas, que eu tinha muita dúvida é para onde, apesar, de morar num bairro muito... muito próximo daqui, eu moro em Cordovil.

\section{M: Hum hum.}

Z: Né? Então, um bairro... pega essa linha férrea é bem próximo, eu não conhecia Duque de Caxias, conhecia de passagem, assim. Meu pai tem parente, que mora na Vila Canaã, que...

\section{M: Ah sim.}

Z: É, então, o pai dele, os pais dele são separados, né? Então, era de Campos. Tem uma fase da vida, que o pai vem morar aqui, isso já é casado, já tem filhos, é... e aí vai morar na Vila Canaã com a família do segundo casamento, já não os filhos do primeiro casamento, são os filhos do segundo casamento é... eles moram na Vila Canaã, então, assim, eu me lembro de passar pelo centro de Duque de Caxias nas poucas vezes, que eu fui visitar a casa dos meus avós, desses, do pai do meu pai, que era na Vila Canaã. Então, era... não tinha uma relação, não conhecia a cidade e aí, quando ficou essas dúvidas, quantas vagas têm pra Caxias, quantas vagas têm pra Niterói, quantas vagas têm pro Rio, a minha mãe me fala: "Faz pra Caxias, aqui pertinho, aqui do lado!" e eu: "Ah, mas, eu não conheço, não sei o que", aí eu fiquei pensando, bom, mas, no município do Rio, eu posso parar em Santa Cruz, Paciência.

\section{M: Tudo distante.}

Z: Tudo longe. Niterói já é distante mesmo. E aí, eu aceito a sugestão dela e escolho Duque de Caxias. Ela costumava brincar, depois que eu passei no concurso, "Que hora, que eu fui mandar você escolher isso!".

\section{M: (Risos).}

Z: Porque aí, assim, a entrada na rede estadual é seguida quase que imediatamente da militância. E aí é viver, né? Você vive muito intensamente o município.

M: Você não tinha antes... tinha uma relação com a militância?

Z: Sindical, não.

M: Hum hum.

Z: Porque a vida profissional começa... começa com...

M: Mas, outros movimentos?

Z: O movimento estudantil na universidade, o C.A. de Pedagogia, basicamente. E uma coisa, que marca e aí, que é uma coisa importante da minha trajetória era o movimento de Igreja.

\section{M: Hum hum.}

Z: Que na verdade, que também, ele se dá na universidade. Então...

\section{M: Na universidade? Da Igreja?}

Z: É, da Igreja Católica. A gente começa... eu começo a militar na pastoral universitária, é... duas amigas da Pedagogia, né? Uma, que era da minha turma e uma outra mais velha, de uma turma mais à frente são as referências, que me convidam, para esse grupo de pastoral universitária, que foi criado, na época, muito inspirados na JUC. 


\section{M: Hum hum.}

Z: Tanto, que logo depois, um dos conflitos que a pastoral universitária vive é exatamente o fato de ser pastoral, não ser um movimento leigo, independente da diocese e... e aí em 84 é o marco da criação do movimento de cristãos universitários, que é meio, que um racha da pastoral universitária. A pastoral universitária é um movimento nacional, então, ela acontece organizada de acordo com os cursos da universidade. Então, eu era do grupo da Uerj, que tinham umas pessoas da Pedagogia, da Engenharia, tinha alguns outros cursos, mas, o grupo mais forte era esse. A UFRJ tinha vários núcleos, a PUC tinha núcleo, é... e tinha no Brasil todo e uma reflexão forte... muito mais forte em outros lugares do Brasil, do que no próprio Rio dá origem ao movimento de cristão universitário, que acaba sendo racha da pastoral universitária. Que quando eu rompo com o meu grupo da Uerj, assim, rompo, nesse sentido de que o meu grupo não concorda com a fundação do movimento cristão universitário, e eu me engajo no movimento de cristãos universitários, o MCU, pelo mesmo esse tempo ainda de vida universitária, né? $\mathrm{E}$ depois, começo a trabalhar eu... é... me afasto da universidade, a universidade não é mais o foco, o foco de fato, passa a ser o trabalho.

\section{M: Hum hum.}

Z: Eu acho, que eu falei um pouco da minha origem (risos).

M: Mas, você não tinha nenhuma relação com a Igreja Católica antes de entrar...

Z: Não.

M: Nem os seus pais eram envolvidos?

Z: O meu pai sempre foi muito católico. Minha mãe, não tinha religião... nunca teve religião nenhuma, é... e a minha avó materna, né? Era batista e ela tinha uma certa posição meio contrária a estimular filho a ter religião porque a minha vó obrigava a ir, para igreja batista, e minha mãe os filhos dela iam decidir o quê que eles iriam ser. Mas, o meu pai era frequentador da igreja católica, mas, eu não fiz, não fiz $1^{\mathrm{a}}$ comunhão, quando eu era criança, nada disso.

\section{M: Hum hum.}

Z: Tem uma fase, que você vai na igreja um pouco por influência, até porque começo a fazer grupo de catequese, mas, abandono, eu e minha prima. A gente foi fazer $1^{a}$ comunhão já numa outra idade por movimento próprio, que era uma coisa... toda adolescência, você se aproxima um pouco de novo dessa coisa, de onde vem, para onde vou... E aí, a igreja aparece, como... é... e aí, eu vou para o grupo jovem, coisas de amigos, que convidam também e no grupo jovem, eles organizam uma catequese para os jovens que não são... que não tem a $1^{\mathrm{a}}$ comunhão. Então, eu e mais 7 , junto com a prima e mais outros, mais ou menos uns 7 jovens, fazemos $1^{a}$ comunhão no grupo jovem, isso um pouco antes de eu entrar para pré-vesti... entrar na universidade.

\section{M: Hum hum.}

Z: Então, tinha uma história com a igreja, mas, essa história é... até tem uma vivência forte, curta, mas, não... é um vínculo, que não fica muito estabelecido e a discussão que se tem na própria pastoral está muito, é muito mais para frente do que do grupo jovem. Porque é uma discussão, que se vai pensar no cristão. O cristão no Brasil, naquele momento político e muito influenciada pela teologia da libertação, nossas referências eram Leonardo Boff, Dom Pedro Casaldáliga... Então, era um pouco por aí. Então, essa é uma história importante da minha formação política, sem dúvida nenhuma. Então, porque quando... tanto, que o movimento de procurar o sindicato, de se organizar, não é o sindicato, que procura, né? O movimento, que... já estava estabelecido, o SEPE era muito escondido. Não tinha núcleo, dentro do Armanda Álvaro Alberto, não tem nada, não tem nada nessa época, não tem funcionário. Não tem coisa alguma, então, você tinha que correr atrás, para encontrar o SEPE. E eu me lembro, que da minha escola, da escola, que eu entro, que entra uma galera grande, tenho eu e uma outra... uma outra militante dessa época, era uma menina novinha também, que entra, como professor II, que ela não tinha feito ainda pós-graduação, ia fazer depois. É... eu não... não me lembro bem qual era a história da formação dela, da Deise, mas, eram duas pessoas, que vão atrás do sindicato, eu e ela.

\section{M: Catar.}

Z: Catar o sindicato porque é... a gente já tinha um pouco estabelecido, que era importante esse espaço, era importante já, que a gente agora era trabalhadora da educação, estar nesse espaço, a gente vai atrás do sindicato. Mas, aí... como logo depois vem uma greve importante. Então, a gente... o movimento em si também vai, a gente vai encontrando as pessoas, vai criando referência 
M: A greve, que você diz, é a de 85 .

Z: 86.85 é muito rápido. 85 tem alguns dias de paralisação, mas, ela desemboca com peso em 86 .

M: Hum hum.

Z: É o último ano do mandato do Brizola.

M: Hã.

Z: Mas, é a greve, que a gente consegue estabelecer a reivindicação, para eleição para diretor. Consegue estabelecer é... consegue começar a desenhar o plano de carreira da rede estadual. É uma greve muito importante. Foi uma greve, comparada depois, com... que na educação gente não está acostumado com greves longas, né? Fala assim: "Ah, nem foi uma greve tão longa!", foi uma greve de quase um mês, foi uma greve significativa e com muita gente nova na rede. Então, tinha uma ameaça aí para os novos da rede, essa coisa toda, mas... é... ali solidifica a relação com o sindicato naquele momento.

M: Hum hum.

Z: Fica mais forte.

M: E você chegou a entrar na rede municipal, depois do estado?

Z: Na rede municipal, eu nunca fui da educação.

M: Hum hum.

Z: Vou fazer o concurso da rede de 92 pra... pedagoga da rede, na época, faço o concurso, tenho um certo estranhamento desse cargo, como eu conhecia muito o plano de carreira da rede, que a gente ajudou a formular, é... sabia que não tinha na educação cargo de pedagoga, você tem orientador educacional, eu não tenho pedagogo. Então, depois que eu passo, que eu fico sabendo, que o cargo é para ser da ação social, mas, eles não chamam.

M: Ahé.

Z: Eles só chamam em 94.

M: Ação social?

Z: É. Ação social, nessa época, ela não tem... não tem cargos próprios, né?

M: Hum hum.

Z: Ela não... ela não tinha, não tinha in... até hoje, eu não sei como eles montaram esses cargos da ação social. Enfim, ela... se utiliza muito de concurso da área de saúde e da pedago... por causa da educação, mas, esse concurso também foi grande do município, não foi um concurso só para educação.

M: Hum hum.

Z: E esse cargo era para trabalhar nos abrigos da ação social, é um lugar, que trabalha com ado... criança e adolescente do município. O município, na época, tinha 3 abrigos, tinha o Reviver, que era de criança. Na época, não tinha essa divisão, mas, quando eu entro começa com essa divisão, mas, eles tinham o Reviver, o Renascer e... o que atende meninos... como era o nome, daquele que ficava ali...? Ah, me deu um branco agora, não me lembro.

M: Favo de mel?

Z: Não, Favo de Mel nunca foi da prefeitura. O projeto, naquela época, nesse lugar era ser uma república, eles tinham os desenhos de abrigo, um trabalho com a população de rua, quem formulou na época tinha esse trabalho. A ideia era... você trabalha com os meninos na rua e convida... é... leva para conhecer o abrigo e se ele... e eles decidem, se ficam ou não ficam na instituição. Se ficam, assumem alguns compromissos de regras de funcionamento, é mais ou menos esse o projeto e a ideia, assim, como as... quando faz 18, né? É... acaba a política de proteção social e o que muitos, de fato, não iam ter nenhum tipo de... é... de estímulo porque não tem família para isso, não tem história, as pessoas, na época, já sabiam disso. A ideia é casa de passagem, não, me deu branco, passagem foi criada depois. Bom, enfim, essa casa era... a ideia dela é que ela fosse uma república, isso nunca foi efetivado e pouca... teve um ensaio muito curto disso, mas, aí tinha os abrigos, quando eu chego pra trabalhar, essa proposta inicial de trabalhar com eles na rua, convidar... já estava acabada, a gente já estava muito institucionalizado... trabalho via ajuizado, recebimento é... ou pelo conselho ou pelo juizado, mas, o conselho ainda era muito incipiente naquela época, depois, que vai 
ficar mais forte, essa coisa de receber os meninos via conselho tutelar, mas, esse trabalho na rua com os meninos, essa coisa do convite, eles aderirem, isso, quando eu chego já morreu e as casas são divididas. Então, apesar de ainda ser misto, ser uma casa de meninas e meninos, o Reviver passa a ser a casa das crianças, a casa da faixa etária de até 12 anos e o Renascer, quando fui trabalhar passa a ser a faixa etária de 12 a 18, ainda mista, né? Um pouco mais na frente deixa de ser mista, então... aí sim, a casa, que era... a tal ideia era ser uma república, passa a ser a casa das meninas de 12 a 18 anos.

M: E não seguia política nenhuma para entender esses alunos de 18 anos para lá. Continua...

Z: Então...

M: Separado...

Z: É... na verdade, eles não são mais protegidos pelo ECA, né?

M: É.

Z: Então, não tem... não tem... é... eles não criam, não criaram nada, quando eles conseguem criar o único abrigo para população de rua, não sei, se hoje mudou, tem 5 anos, que eu não estou mais no município. Mas, eles conseguem criar um único abrigo, é um abrigo para adultos, eles não têm essa especificidade de trabalhar com os jovens e de trabalhar com esses jovens, no sentido de ter um espaço, que eles tenham maior autonomia porque na instituição, eles têm pouca autonomia.

M: Hum hum.

Z: Quem tinha mais autonomia e que o recurso social seja muito mais um apoio logístico, mas, que ele se responsabilizava pela sua manutenção e... é... isso teve um ensaio muito curto lá nessa casa... agora me deu um branco completo, gente! No nome, mas, que se transformou depois na casa das meninas, de adolescentes, né? Originariamente, era no centenário mais ou menos, é, acho que era ali numa ruazinha ali pelo centenário, ali para dentro e depois, a gente vai cada hora... tudo é espaço, que não é, que não é da prefeitura. Quer dizer, o Renascer, quando eu vou trabalhar, é ainda Manoel Teles, é... e aí até, que a Prefe... perde o controle completo da instituição e... fica na boca da favela ideal, não sei, né? Uma época, que... diversos erros aí, tem uma... acho que fica muito permissiva e perde o controle dos meninos, há uma intervenção gerida pelo próprio Ministério Público, que o... a prefeitura disse, que os níveis de..., alguém vai dirigir a casa e logo depois, quando há a mudança de gestão de governo, é... a gente é tirado dali, na verdade, assim, se troca de lugar com o Reviver, o Reviver vem pra cá, para o que fazer... o Reviver vem pra cá e o Renascer vai, então, pro São Bento, né?

M: Hum hum.

Z: Aquele lugar caindo aos pedaços do São Bento (risos). Mas, eu na prefeitura, a trajetória não foi só na educação.

M: Hum hum.

Z: Né?

M: Mas...

Z: A minha militância forte no sindicato, é uma história com a militância da educação. Na prefeitura, a minha história não é na educação.

M: Me conta mais, então, dessa... dessa militância na educação. Foi aqui em Caxias, mas, foi pela rede estadual, né?

Z: Então, é... na época em Caxias, a gente tinha a APPMDC, que era a Associação dos Professores da Prefeitura de Duque de Caxias.

M: Você entrou e já estava criada?

Z: A APPMDC sim e... o SEPE Caxias. É... então, a gente tinha essas duas instituições. No SEPE havia uma série de discussões, o SEPE, na época, ainda era CEPE com C. CEPE, centro de professores do Rio de Janeiro. No SEPE, a gente tem é... várias discussões que são colocadas quando eu entro no SEPE, na verdade, é... o... Caxias é o núcleo de oposição, direção central do SEPE porque a direção, a antiga professora Eudésia, a remanescente do Godofredo Pinto, é... havia as grandes divergências... era filiação à central única dos trabalhadores. Na verdade, apesar do SEPE ser criado com esse caráter. De uma... de sindicato de fato, apesar de não ser de direito porque a legislação, na época, proibiu os funcionários públicos de ter sindicato, é... então ele é criado com esse caráter associativo, mas, ele é na prática um sindicato, ele tem esses moldes de dar 
independência. Porque você, desde o início, você vai sustentar o sindicato com recursos próprios que não advêm de imposto sindical. Então, ele já tem um pouco... esse caráter novo, mas, a direção da época, ela ainda estava muito é... identificada com... digamos assim, com políticas, a gente considerava atrasadas em termo sindical. O que mais... Era o discurso predominante do corpo, que unificava a oposição, na época, que aí tinha de tudo, mas... unificava a oposição essa visão de que a importância da Central Única dos Trabalhadores, o sindicato, novas bases filiadas à Central Única dos Trabalhadores. O SEPE não era filiado a nenhum tipo de central e não queria... a direção era contra essa filiação a CUT. Então, tinha esse embate e o outro embate era a questão da unificação dos trabalhadores, o sindicato não fosse um sindicato de professores, mas, um sindicato dos trabalhadores em educação. Então, a unificação com a APPMDC aqui, ela vai no bojo dessa discussão, quer dizer, quanto mais esse sindicato for amplo, né? É... tiver organizado mais forte serão essas lutas.

M: Hum hum.

Z: E a gente tinha, na época, uma referência de militância importante aqui para essa unificação porque era uma militante muito reconhecida na base da categoria. E que aí, que também era militante da rede estadual, então, essa ponte de discussão, ela... ela é feita com muita tranquilidade. E o processo também, muita discussão com a categoria, seminários de preparação até que a categoria aprova unificação com o SEPE.

M: A nível central?

Z: Porque o SEPE... o SEPE é... é único.

M: Hum hum.

Z: Na verdade, não tem mais de uma instituição porque tem núcleos municipais, mas, o SEPE aqui, ele é representante, tem direção própria, mas, ele... o seu estatuto naquela época já previa isso, né? $\mathrm{O}$ Rio dividido em regionais e o interior, as próprias cidades, então, as direções locais, mas, o sindicato é o mesmo. A organização é que se dá com esse lastro. Então, quando há a unificação com o SEPE, é com... com o SEPE. Agora, quem representa é a direção local. Quem representa a categoria perante essa direção... a direção do núcleo municipal do SEPE, do núcleo de Duque de Caxias.

M: E quem era direção do núcleo de Caxias no momento? Você fazia parte já?

Z: Fazia parte já dessa direção.

M: E já era colegiada já? Ainda não?

Z: Quando eu entro, logo no início, não. Não vou te dizer exatamente o ano, mas, quando eu entro não. Quando eu sou presidente do SEPE Caxias. É, como eu falei, a gente que é do núcleo municipal de Duque de Caxias, ele era um núcleo, que tinha oposição ao SEPE...

M: Rio...

Z: É a direção do SEPE Rio.

M: Hum hum.

Z: Direção do SEPE Central, como a gente fala. É... a militante referência, que era a Olga.

M: Hum hum.

Z: E, quando a gente faz, então, o congresso do SEPE, a gente aprova essa filiação à Central Única de Trabalhadores e a unificação do SEPE passar a ser sindicato, a direção do... da Eudésia pede renúncia.

M: Hum, não aceita a derrota.

Z: É, ela pede renúncia e, como ela pede renúncia, é montada uma direção provisória. A Olga vai para essa direção provisória do SEPE, é... junto com outros militantes do SEPE Central, logo depois, conduzem as eleições, eu sou candidata aqui, é... para direção daqui, como presidente do SEPE Caxias. Trajetória rápida, né?

M: (Risos). Já ia entrar já se candidatando, praticamente.

Z: (Risos). Já vira direção, é. Então, é uma coisa, que é bastante rápida.

M: Hum hum.

Z: Eu não vou ainda para direção do SEPE Rio, depois, que eu vou para direção do SEPE Rio. 


\section{M: Hum hum.}

Z: Aí já é um outro momento, eu já era direção do SEPE Caxias e... tinha uma... e aí assim, a discussão, que se estabelece é dos limites da militância sindical. Porque aí assim, eu estava no sindicato, por reconhecer no sindicato a sua importância na luta dos trabalhadores, mas, a minha posição maior não era só essa luta, era transformar a sociedade. E nesse sentido, o sindicato tinha seus limites. Obviamente, já estou filiada ao partido dos trabalhadores, mas, nunca tive uma militância orgânica no PT. Mas, eu me aproximo de uma tendência do PT, de um... A partir da educação, de militante da educação, a partir de uma reflexão sobre o sindicato. Eu me aproximo de uma... de uma tendência dentro do PT, que é a força socialista e a partir daí, que eu vou para o sindicato SEPE Rio porque até então, a minha tendência era me afastar do sindicato mesmo porque... toda crise, que você tem, ser direção sindical trabalhar, cuidar e se você não está num bojo de uma discussão política, mais ampla, é... eu vejo com... pelo menos, para mim isso era insuficiente, ficar na direção do sindicato, sem uma direção política mais ampla.

M: Hum hum.

Z: Então... e isso me faz continuar no sindicato e aí me faz ir à direção do SEPE Rio, primeiro como vice da região da baixada, a $1^{a}$ chapa. Quando eu vou para o SEPE Rio, então, eu continuo aqui e sou vice do SEPE central, têm umas regiões divididas, aí eu peguei região São João, Caxias e Magé, uma vice região, que tem ali na chapa, sendo diretor por essa região. Na outra chapa, já vou pra... pra... já é colegiada e eu já vou para a coordenação geral do SEPE.

M: Hum hum.

Z: Então, eu e outros colegas, essas pessoas vão na coordenação geral do SEPE. E nesse momento, que marcou muito a gente na reflexão, sobre organização sindical, a gente monta uma tese para o congresso do SEPE, chamada tese 3 . Eu esqueci de trazer para você ter acesso a tese é... a gente monta essa tese 3 e... era uma coisa única, aqui no SEPE, no SEPE aqui porque era um outro lugar aonde...

\section{M: (Risos).}

Z: Aonde, digamos, a esse momento que eu fui fazer a parte do PT, força socialista, se articulava com a articulação do PT. Os militantes da articulação no SEPE, nós éramos muito próximos deles, então... era um outro lugar no Rio onde essas duas tendências faziam aliança, de militância e a gente assina junto essa tese para o congresso, que eu acho, que é um marco na trajetória do SEPE. A gente é derrotado no congresso e é derrotado, posteriormente nas políticas, é... que o sindicato leva, mas, eu acho, que isso é um marco, assim, no... isso não começa ali, óbvio, que eu coloquei, a gente já era, Caxias, ele é um núcleo de oposição ao SEPE Rio, a direção central do SEPE e do ponto de vista da luta política, eu não tenho dúvida do acerto das suas propostas. Outra coisa, é me dizer, se hoje, afastada no tempo e no espaço, é se as propostas, elas, elas de fato representam um nível de... representa... quando eu falo representam, não é no sentido de que... a gente tem uma categoria que é massiva, então, é óbvio, que vão sempre circular diversas visões de mundo internamente, mas, no sentido de ter conseguido consolidar mais isso perante a categoria, né? Eu acho, que a gente vai cada vez mais para uma trajetória, que é de vanguarda, vanguarda, vanguarda, vanguarda. As direções do sindicato... se elas forem de fato, pelo caminho transformação, elas vão ser sempre vanguarda. Elas vão estar é... vão representar o núcleo, digamos central da categoria, elas têm que pensar o mundo e a política de maneira mais ampla, mas, acho, que elas não podem ficar tão descoladas, descoladas de um processo de organização, de reflexão, para que a categoria faça na luta.

M: Hum hum.

Z: Dirigir a luta, é... chamar a atenção para determinadas questões. Perceber, que a importância de ir para além do corporativo, tudo isso é papel de uma direção, mas, acho que você não pode estar tão, tão à frente, que daqui a pouco você não consegue mais representar o que essas pessoas de fato pensam. Que elas...

M: A base.

Z: É a base. Eu acho que... que ao meu ver, assim, quando a gente lança a tese 3, a gente queria chamar a atenção, aí tem questões pontuais, aquele contexto, chamar atenção sobre isso, chamar atenção da importância do sindicato ter um nível de representatividade da base fosse importante e eu acho, que o caminho, que a gente toma é outro. É o caminho de ser cada vez mais vanguarda mesmo.

M: É... 
Z: Aí é óbvio, como qualquer... vai ter momentos, onde... o arroxo, uma série de... trazer mais de perto a categoria, para determinadas é... lutas e outros momentos não. Sem dúvida, o SEPE se torna é... ele cresce na sua capacidade organizativa, estrutural. Como eu falei, de um sindicato que começa a militar na década de 80 , que não tem um real.

M: (Risos).

Z: O SEPE central não, o SEPE central tinha.

M: Já tinha.

Z: Já tinha sede na rua Senador Dantas, uma sala importante, enfim. Porque tinha uma... uma contribuição grande da categoria a nível do estado e a nível do... do...

M: Município do Rio.

Z: Município do Rio de Janeiro, mas, os núcleos municipais, eles não tinham, o núcleo de Caxias também não tinha e... e... você tem, tem a estrutura, que você tem hoje.

M: Você acha, que Caxias está indo na frente ou...

Z: Mas, o SEPE central também, ele também cresceu muito em termos da sua capacidade econômica, estrutural, enfim. E isso tem a ver com as lutas, com essa organização, então, isso é inegável.

M: Hum hum.

Z: Por outro lado, é... você não consegue fazer com que... é... de fato a categoria se... é... você de fato esteja mais enraizado dentro da... dentro da organização, dessa categoria, eu acho um pouco isso, né? Agora, isso não tira o seu papel fundamental na luta dos trabalhadores. Assim, você pensa é... quando você pensa assim, o SEPE é uma das referências mais importante em termos de luta, né? No estado, né?

M: Com certeza.

Z: E, quando eu entro... eu vou depois para universidade, para UFRJ. Então, já entro num outro momento. É óbvio, que os trabalhadores da educação lá na universidade também vivenciaram isso, que eu vivenciei na história do SEPE, quando já chegou lá, a direção, né? Já está, o SINTUFRJ já existe, já está, digamos assim, mais consolidado, as grandes lutas já, já..

M: Já estão...

Z: Já passaram..

M: Você entra na UFRJ, como professora ou no mestrado?

Z: Como técnico, como técnica.

M: Ah, como técnica.

Z: Como pedagoga, mas, na carreira técnica.

M: Nisso, você ainda está envolvida no sindicato?

Z: Ainda no sindicato, me afasto logo depois.

M: Hum hum.

Z: É... Mas, uma coisa, que me assustava era, como a greve lá, era uma greve figurativa. Você tinha na universidade plantões nos setores e a categoria desaparecida e, quanto isso, chegou uma maneira, que tinha um consenso, é... o sindicato, isso não era um conflito. Isso não é um conflito, era o que era possível a maneira da história, isso nunca foi possível aqui, eu acho, que apesar de... como eu falei, que às vezes, a gente se torna muito vanguarda da vanguarda, por mais, que isso esteja acontecendo, as greves da educação sempre foram greves de enfrentamento, de embates, de confrontos, é...

M: Participação.

Z: Sim, então, a participação é a sua marca, com dificuldades, né? Ou com alta participação, ou com média participação, as greves são marcadas por isso, não há um... um...

M: Esvaziamento.

Z: Esvaziamento, um... isso não está posto. A gente sempre tem esse enfrentamento, então, da minha parte, então, há um estranhamento muito forte com o que eu encontro em termos de organização dos trabalhadores na universidade e, quando eu faço essa crítica dessa questão, que a gente tomou um 
caminho, que foi de vanguarda, é... foi com as ações das lutas. De uma forma... que o núcleo de Caxias sempre resistiu. Eu acho, que essa é a diferença, quando você pensa em termos de organização sindical para rede municipal de Duque de Caxias, essa é uma diferença fundamental, a proximidade que a direção sempre buscou ter com a sua categoria. Essa relação mais próxima, essa coisa de... de conseguir ouvir as escolas. Então, é... esse marco, acho, que óbvio, que eu estou afastada hoje, não sei dizer mais, como está o SEPE Caxias, mas, assim... isso durante muito tempo é... refletia a diferença em relação aos núcleos municipais.

M: Hum hum.

Z: É... você sempre teve uma categoria, que é aguerrida, tanto na rede estadual, como da rede municipal, quando você ia para as passeatas no Rio... para os embates, quem estava de frente era a mulherada de Caxias, era a uma mulherada sempre de enfrentamento. Claro, tem de tudo nas escolas. Você encontra de tudo, mas, todo núcleo participativo, o núcleo que está presente, sempre foi um núcleo muito aguerrido, de muita força. É... então, acho, que tem um pouco isso e tem essa preocupação com um sindicato, que fosse... o sindicato mais colado com a base, eu acho, que... que é isso que a gente tenta marcar com a tese 3, essa preocupação com os caminhos, que o SEPE estava tomando, mas, que a gente em termos de organização do SEPE, como uma instância do estado todo, a gente é derrotado, a gente perde essa... essa... essa... essa posição que a gente defendeu, a gente perde, isso tem uma importância no Congresso, obviamente, tem uma importância, até porque a gente é um setor importante na direção do movimento, mas, a gente perde não só no Congresso, como a gente vai perdendo essa visão paulatinamente nas lutas do sindicato até que chega ao ponto, que a gente discute, se vale a pena permanecer na direção do SEPE. Eu, particularmente, provavelmente iria me afastar porque estava é... um dos meus vínculos do estado, com essa categoria já tinha se rompido porque eu vou para a universidade.

M: Você tinha duas matrículas.

Z: É. E... quando eu vou, venho para... logo depois também era... me afastar porque logo depois, eu fui chamada para a prefeitura de Duque de Caxias, é... mas, a discussão ali não era essa, era uma questão desse grupo pensar, se valia a pena a gente permanecer na direção e a gente resolve renunciar, a maior parte de nós resolve renunciar, não permanecer na direção, a gente faz uma carta, apresenta os motivos... a gente sai da direção do SEPE Rio, é... mantendo quem estava nos núcleos municipais, nas direções locais, as pessoas das direções locais, mas, na direção dessa instância maior, a gente resolve sair.

M: Hum hum.

Z: É... a única pessoa, que permanece nessa direção é... discorda dessa posição e permanece eu não sei se formalmente na direção, mas, logo depois vai ser formalmente na direção é a Francisca.

M: Hum hum.

Z: Que é a militante fundamental que tem uma militância fundamental nessa história da... da gente conseguir de fato, juntar a APPMDC, na verdade, extinguir a APPMDC.

M: Hum.

Z: E passar, então, o SEPE ser a direção dos professores da rede municipal, a militante fundamental de elo é a Francisca.

M: Hum hum.

Z: Tem outras pessoas na direção, presidência da APPMDC nessa época, que foram ganhos, mas, elas não são os sujeitos estratégicos nessa discussão. Não tem essa importância, que a Francisca tem.

M: Entendi. Como é que foi essa articulação da... da APPMDC deixar se fundir com o SEPE?

Z: Então, foi um processo, como eu falei, é... não foi um processo conflituoso, né?

M: Hum hum.

Z: Porque você vai convidando, então, as pessoas, que são referência, que era direção da APPMDC e vai fazendo essas discussões, essas reflexões até que chega a um ponto, onde há um acordo em relação a extinção da APPMDC, e, digamos assim, todo seu patrimônio, as suas questões serem passadas para o SEPE, não é grande coisa, mas, tinha ali um patrimônio dos seus associados. Tem a sua história, tudo isso é incorporado ao SEPE. Isso não foi um...

M: Um conflito. 
Z: Não foi um conflito, mas, porque se teve uma preocupação da forma como isso ia ser feito. Mesmo as pessoas sendo ganhas para isso, o que se fazia era um processo de dirigir junto as assembleias, de estar presente. Então, até que você reconhece na direção, de ir compondo, de alguma maneira, junto e você reconhece, que essa direção é a mesma direção.

M: Hum.

Z: Já não é mais uma direção, que está separada, então... e não foi conflituoso, sugeria porque se teve todo um processo de constituição para isso.

M: Hum hum.

Z: É... provavelmente, tudo isso tem documentado dentro do SEPE, mas, assim, a gente chegou a fazer seminários, discussões locais, acho que teve um pouco isso. Tanto assim, como diz a Francisca eu sou, eu fui da... da comissão, que vai montar no governo Hydekel o plano de carreira da... da prefeitura de Duque de Caxias, era secretaria municipal de educação. E eu não era da categoria.

M: Mas...

Z: Mas era uma liderança que a categoria reconhece. Então, isso não era uma questão, não era uma questão. Mas, acho, que tinha a ver com isso, com essa história, que a gente vai constituindo. Vai debatendo, vai...

M: Essas instâncias, é... conselho de representante, por exemplo, que é uma forma de aproximação da base com a direção... é como é que foi se constituindo o conselho de representante? Não partiu do SEPE central, né? Pelo que eu entendi é mais algo de Caxias do que...

Z: Na verdade, o SEPE central fala de representação sim a nível de escola.

M: Conselho modelo deliberativo. Mas, tem outra característica diferente de...

Z: Não. O conselho deliberativo, ele já é uma instância, que pode ter os representantes sim. E as direções. Mas, nunca teve esse peso, como tem aqui.

M: Hum hum.

Z: Então, também essa é uma discussão, uma decisão da direção local, de jogar peso no conselho de representante. É... ele já tem uma... uma certa importância, quando eu me afasto, mas, eu acho, que hoje a importância dele é bem maior. Acho que ele passa a ser o conselho deliberativo do núcleo municipal, ele passa um pouco a ter essa característica aqui. Então, claramente ele não... ele não tinha esse... não sei, se passou a ter, se fizeram alguma mudança estatutária, ele não tinha esse...

M: Esse caráter.

Z: É. Por força do estatuto do SEPE, ele não tinha. Mas, a ideia embrionária sempre foi essa, um espaço, que de fato você pudesse antes de tomar decisões maiores... que fosse um pouco reflexo da organização das escolas. É... isso está previsto assim, no estatuto do SEPE. Agora, eu acho, que nenhum lugar tem a dimensão, que conseguiu ter Duque de... se não, eu acho, que não seria o que eu acabei de te falar, um sindicato, que caminhou para ser mais vanguarda do que...

M: Que os demais, né?

Z: Hum... não falo que os demais, na verdade, eu falo de um... é um corte sútil, que eu... não sei, se eu vou conseguir me fazer entender, mas, é... era uma preocupação em que os espaços de luta, ainda mais momentos de confronto, são sempre muito difíceis.

M: Hum hum.

Z: E a nível estadual, isso é mais difícil ainda, é óbvio.

M: Articular, né?

Z: É. Mas, de alguma maneira, assim, é... isso ainda acho, existe um limite entre a capacidade de articulação e de desmonte, que um sindicato pode fazer determinadas políticas, ela é sempre limitada. Porque, de alguma maneira, você representa a movimentação dos trabalhadores numa sociedade capitalista.

M: Hum hum.

Z: A não ser, que você consiga romper com essa sociedade e aí você ter um... talvez, um outro caráter, mas, ela vai ser sempre limitada. Então, a necessidade de estar atuando em partidos, de estar pensando a transformação por outro lugar, isso é... eu acho, que é muito importante para militância sindical, para direção sindical. 


\section{M: Hum hum.}

Z: Por outro lado, eu não posso crer, que o sindicato está atrelado a uma política é... da minha visão partidária, ele não deve estar.

M: Hum hum.

Z: Porque por mais, que eu precise estar para além de uma movimentação sindical, para poder, eu acho que tipo, fazer a leitura de um mundo mais ampla e das transformações necessárias e das lutas fundamentais em determinados momentos, o sindicato, ele é plural, ele não pode ser determinado... e eu acho, que a gente... essa visão, essa disputa, a gente um pouco perdeu dessa visão de movimentação sindical. Então, sempre quis falar que tornou sindicato de vanguarda é a melhor forma de expressar essa... essa...

M: Hum hum.

Z: Mas, eu acho, que a gente foi cada vez mais é... pensando nas lutas fundamentais e estratégicas, mas, elas estavam muito afastadas de uma... de um nível de avanço de consciência de classe dessa categoria, de... organização. Por mais limitada, que seja tudo isso, a gente precisava avançar mais nessa organização, para que o sindicato fosse mais de massa. Acho, que... apesar, de toda importância histórica, que o SEPE tem e tem até hoje.

M: Hum hum.

Z: Eu acho, que o rumo tomado foi diferente de um sindicato, que mais estruturado na massa da categoria.

M: A liderança não... a ideia da liderança não, não foi acompanhada pela sua base? Os ideais... é isso?

Z: É... vou pegar um exemplo, que eu defendi arduamente, que fui para um congresso votar nisso.

M: (Risos).

Z: Hã... que era o SEPE se transformar em um sindicato que não fosse só de professores, fosse dos profissionais da educação, é... depois de uns anos, passados alguns anos, claro, eu vou falar mais da militância, e nem mais nas escolas. Mas, afastado um pouco mais, eu fico pensando assim, por mais do acerto dessa proposta, do ponto de vista da luta dos trabalhadores, eu não sei, se ela era acertada do ponto de vista da organização desses trabalhadores, entende? Os professores tinham uma história de organização muito além do pessoal de apoio das escolas, dos funcionários de apoio das escolas. É... além, de ser no espaço das escolas, o sujeito estratégico, quando para a sua ação, de fato, a repercussão daquele setor parar é muito maior do que do pessoal de apoio. Então, tem dois elementos aí, que prejudicam muito a unificação, que é a história de organização desses trabalhadores, que não são docentes da escola, é... e o papel estratégico que os docentes têm. Então, juntando essas duas coisas, eu fico pensando assim: "Até que ponto, que foi à serviço de fato da organização dos trabalhadores, entende?". Quando eu falo: "Não é uma divergência da pauta em si, mas, é o quanto essa pauta, ela está no momento adequado" e óbvio, que isso tem um peso na história assim, você não volta mais lá. Não volta, já era, acabou. Agora, quem é o pessoal de apoio das escolas? Não sei, vocês que tão dentro das escolas sabem mais do que eu hoje, mas, eu fico pensando assim, o quê que você ajudou esse setor a se organizar? A se fortalecer? E aí sim, fazer um trabalho, de trabalhadores, de profissionais da educação, reconhecendo as suas diferenças em determinados momentos, em determinadas pautas, mas, estando juntos na luta. Eu acho, que a gente fez uma coisa mais artificial, do que de fato representativa dos vínculos e história de organização de dois setores, que são diferentes no campo da educação, essa é uma questão. Eu acho, que não é uma questão sobre a qual, as pessoas hoje se debrucem, estejam interessadas, mas, eu fico pensando, o quanto, na verdade, o pessoal de apoio foi atropelado pelos docentes. E foi atropelado e isso foi direção, que a gente deu para o movimento. Então, quando eu falo disso, eu... o motivo, eu nem sei mais assim, nesses dias se a categoria acompanha porque eu não sei, mas, se a categoria também tem essa reflexão hoje, se ela pensa sobre isso. Agora, é... porque hoje está dado, esse sindicato é um sindicato, por mais, que domine os seus professores, está dado, que é um sindicato dos trabalhadores em educação, a gente monta as pautas e vai para as lutas e... e negocia questões de uns e de outros, mas, vai para as lutas juntos, pelo menos, pelo que eu acompanho. Isso continua é... se dando.

M: Hum hum.

Z: Mas, eu não sei, se isso reflete o nível de organização se isso reflete o nível de organização dos funcionários e assim, você vai ter em outras questões, entendeu? Que o sindicato vai tomando. O colegiado, necessariamente, eu não acho, que tenha sido um equívoco uma direção colegiada, mas, 
a proporcionalidade, eu saio logo depois. Mas, eu não estou lá na direção do SEPE, quando ele aprova a direção proporcional e acho, que hoje é tão proporcional, que basta ter essa chapa, que você está na direção. Não importa a representatividade que você tenha de volta, acho isso... sinceramente, eu acho isso um erro, é... direção tem que ter responsabilidade, né e, se você é... tudo bem, você vai ter setores minoritários representados, mas, o nível de representatividade desse setor tem que ter na categoria, porque ele tem que ser responsabilizado pelas suas posições, pelo o quanto está construindo o sindicato ou não está. E não é o que a gente vê. Mas, se você pensar, isso é supervanguarda, ora, por que não? Todos, é super democrático, ter todo mundo representado. Eu não sei, se isso fortalece o sindicato, eu tenho minhas dúvidas se fortalece o sindicato porque a massa da categoria, ela não tem ideia dessas coisas, entendeu? Ela não vive esse processo, é... cotidiano de idealização, das decisões... E... quando as coisas acontecem e dão errado, ela vai culpar a liderança, que ela reconhece. A direção, que ela reconhece, e muitas vezes, a direção está passando o seu cotidiano uma confusão, para administrar a luta, administrar esse sindicato. Então, assim, esse é um exemplo. Agora, no maior, quando você pensa, poxa, superinteressante você ter teoricamente diversos setores, juntos, dirigindo o movimento, representados na direção do movimento, só que na prática você sabe, que as pessoas não funcionam assim, as coisas não funcionam assim, entendeu? Então, quando eu falei um pouco assim, a gente foi tomando um rumo, que é um rumo, que é mais afastado de uma reflexão que seja da massa, que a organização sindical mais próxima do que de fato a categoria pensa ou, que consegue estar organizado, refletir, nunca vai ser a mesma coisa, mas, um pouco mais solidificado, com esse nível de organização, era disso, que eu estava falando.

M: Hum hum.

Z: Eu acho que a gente tem algumas práticas nesse sentido, mas, se você pensar, não é uma coisa que está no SEPE, é uma coisa, que está em todos os setores, que hoje é... que vêm dessa história. Então, no SEPE, está em outros sindicatos, outras direções de movimentos. É uma visão que... política, que de alguma maneira dirigiu, conseguiu dirigir e... ser vitoriosa na direção de movimentos sociais.

M: Deixa eu voltar um pouquinho aqui na sua... na sua história (risos). A sua formação, você foi, fez a Pedagogia, né? Especialização em educação especial, depois você falou, que foi procurar um mestrado.

Z: Ah bem mais tarde!

M: Foi concomitante com a...

Z: A história do mestrado... não, não, não, mestrado é bem mais tarde.

M: Você já tinha saído da rede?

Z: Já.

M: Você saiu da rede para ir para onde?

Z: Primeiro...

M: Para ir... para educação.

Z: Primeiro, eu passo nesse concurso pra UFRJ. Eu fiz concurso da UFRJ e da prefeitura de Duque de Caxias juntos, no mesmo ano, só que a UFRJ chama primeiro e a... a prefeitura, chama bem mais tarde. Então, eu saio primeiro para UFRJ, depois para própria prefeitura de Caxias, mas, á eu... é... quer dizer, os dois eu continuo trabalhando com a educação, mas, formalmente, eu não sou mais funcionária da Secretaria de Educação.

M: Hum hum.

Z: Nem do estado e nem da prefeitura. É... e o meu afastamento do SEPE é uma decisão política, que eu coloquei para você, o grupo, que a gente compunha a direção, o SEPE Rio, a gente decide sair da direção, é... E nessa época...

M: Antes de terminar o mandato?

Z: Antes de terminar o mandato e depois com... com... o... com a falta de vínculo profissional, eu me afastando mesmo da direção do movimento.

M: Hum hum.

Z: Porque assim, eu não era mais base e também não era mais direção. Então, aí é uma decisão pessoal a nível de vida mesmo. De... dar um outro rumo para vida, fazer outras coisas naquele 
momento, é... então, eu me afasto da direção do SEPE e o mestrado é na época de 2000. Então, é bem mais tarde.

M: Já tinha se desvinculado.

Z: É já tinha me desvinculado mesmo dali, é, daqui do município. É... quer dizer... na verdade, me desvinculado de ser direção, de estar no movimento, agora, dessa história nunca foi desvinculada. Porque as raízes estão...

M: Fincadas.

Z: Fincadas aqui. Porque, como disse a minha mãe, depois, que eu fui trabalhar em Caxias, virei Caxias.

M: (Risos).

Z: É um pouco, assim, então, na verdade, assim, você vive uma militância também tem um pouco isso. Você vive muito fortemente as escolhas, que você faz. Então, os amigos, as referências, elas tão enraizadas aqui nesse lugar. E eu trabalho no... eu trabalho aqui durante... trabalho de 85 a 2012 em Caxias, então...

M: É uma vida, né?

Z: É uma vida, são quase 30 anos.

M: Você não saiu aposentada?

Z: Não, não.

M: Quase, né? 25 anos de rede...

Z: É, mas, acontece, que eu não sou da educação.

M: Ah é verdade.

Z: E... então, o tempo da aposentadoria seria maior e, quando eu saio da prefeitura, eu tenho 18 anos é na prefeitura, mas, eu saio porque eu faço concurso para o tribunal e aí eu vou me embora para o tribunal de contas (risos) começar uma outra história.

M: Que não é... que não tem nada a ver com a educação.

Z: É educação, eu trabalho em escola do tribunal, sou pedagoga.

M: Ah escola!

Z: Eu faço um concurso, o cargo é o mesmo de qualquer analista do tribunal, qualquer auditor do tribunal é analista de controle externo, mas, a especialidade, eles abrem uma vaga para especialidade em Pedagogia e é... é nessa vaga, que eu concorro. Então, na verdade, eu continuo trabalhando com educação. (rindo)

M: (risos)

Z: Só, que com um outro foco, uma outra área. Eles têm uma escola, que se chama de Escola de Governo e... sou lotada no tribunal, mas, trabalho dentro da escola com assessoria pedagógica da escola, então... é educação.

M: É escola.

Z: É educação, é escola.

M: Interessante.

Z: Mas, só não é mais a educação básica. Que tem... que para minha história pessoal, ela é fundamental. Acho, que de importante, não sei, te colocar aí é assim, a... acho, que eu coloco no início que eu faço o concurso de 85, que é um concurso muito grande de vagas abertas durante o governo Brizola. É... o quanto o chão da escola, naquele momento, naquele contexto é um lugar de transformação.

M: Hum hum.

Z: Porque você se engaja na luta, mas, sempre pensando a escola, claro, nas questões salariais, nas condições de trabalho, isso é sempre pauta, mas, a luta que a gente leva até a década de 90 , até o final da década de 80 são lutas, são... o foco na escola é muito forte. Tanto, que a eleição para diretor é uma coisa importante e eu me lembro, que quando eu entro na escola em 85 é... uma das nossas reclamações, assim, o grupinho começa a se articular, era da falta de reunião da escola, a escola não 
fazia reunião, aí a gente ia conversar com a OP da escola e ela, obviamente, adora essa fala, esses docentes novos tão chegando, querendo reunião pedagógica. Ela é uma aliada nessa história, tanto na militância do sindicato, posteriormente, como em criar esse foco é... de organização da escola, só que, quando eu falo da minha escola, isso não aconteceu na... quando você vai ver isso depois, isso não se dá só nessa escola, mas, se dá em outras.

M: Qual que é a escola?

Z: Lara Vilela.

M: Ah...

Z: Aí uma das coisas, que... que acontece lá e vai acontecer em outras também é logo depois da greve, é que os diretores caem. A gente consegue colocar, não tinha eleição ainda.

M: Eram indicados políticos.

Z: Eles eram indicados em cargo político, mas, eles eram tirados. E uma das coisas, que você consegue, aqui em Caxias era... era... ah! A coordenadora da CRE venha para reunião dos professores, para legitimar quem é o docente que a gente indica para direção. As pessoas são sábias, ninguém indica (risos), vai indicar alguém, que sempre tenha passagem, que vai passar nesse momento, mas, essa é uma marca, isso se dá em várias escolas. Então, você não tem ainda conquistado a eleição para diretor e óbvio, que o núcleo, que decide ainda é o núcleo dos professores. Não é uma coisa da comunidade escolar decidindo, então, é muito fruto dessa luta da greve de 86 , mas, isso vai se dar em várias escolas. Então, é... porque tinha essa preocupação em transformar as relações dentro da escola, transformar o espaço pedagógico, isso está muito entranhado, então, assim, eu vejo, quando eu falo da formação do sindicato, mas é o quanto essas lutas ajudaram, naquele momento, é... a transformar a escola e na aposta, que a gente fazia da escola como um espaço possível de ser transformado, possível de ser constituído, é... construir os seus projetos pedagógicos. Isso estava muito, muito presente. Então, assim, é... as lutas e a escola, ele é um marco de formação fundamental, eu falo assim, a minha grande escola, por mais que o meu... quando eu penso assim, tantos anos de trabalho, eu já rodei muitos lugares, mas, o grande marco de formação foi a escola estadual e foi a escola estadual dentro desse contexto, de organização, de luta, de reflexão. Aí tem várias reflexões, por exemplo, eu era uma, que quando saiu do curso de Pedagogia, defendo arduamente as habilitações (rindo), orientação...

M: (Risos) Defesa de campo.

Z: É, mas, que... pouco tempo na escola me faz desconstruir essa defesa. Pensar a importância da articulação do trabalho pedagógico, do trabalho escolar. Então, assim, do pedagogo, como uma figura importante nesse trabalho e aí, não ajuda muito a divisão entre orientador educacional e orientador pedagógico, nesse sentido, é óbvio, que tem que ter um trabalho, a gente tem que trabalhar com os alunos, a gente tem que trabalhar com os pais e tem que trabalhar com os docentes, mas, esse trabalho tem que ser articulado. Então, a defesa tinha muito... a especialização, que você tinha que ter com foco no aluno.

M: Hum hum.

Z: Isso com pouco tempo de escola, da minha cabeça já está desconstruído, isso não é mais fundamental. Esse sujeito, que consegue olhar formação humana, pensar formação humana, pensar a especificidade da formação humana naquele contexto, naquela faixa, naquele... e com aqueles sujeitos, esse cara tem um papel muito importante na escola, tanto, que eu cobro muito dos cursos de Pedagogia.

M: Hum hum.

Z: É... e cobro muito do papel dos profissionais de formação, que tão formando. Esses outros porque os fatores... o fator nunca é um só. Mas, eu me lembro assim, o quanto nós lutamos, para que o reconhecimento do pedagogo da escola, o reconhecimento do concurso para área e foi uma coisa que a gente conquistou, a gente conquistou aqui em Duque de Caxias e conquistou em outros lugares também. Ah tudo bem, a gente pode ter conquistado aqui condições salariais melhores, mas, a gente conquistou... esse não é o único elemento, mas, esse profissional, ele é muito importante, agora, ele precisa ter formação política, ele precisa enxergar, o quê que tem que fazer na escola.

M: Não dá para ser um técnico (risos) só.

Z: É porque eu acho, que o técnico... as escolhas são sempre, tem sempre uma geração política. Então, assim, é... depoimentos, que aí... é... não dá para ser o cara, que vai enfeitar o mural da 
escola, pensar em frasezinha de mural de escola, isso não dá. Tem que ser alguém, que consiga de fato fazer com que os docentes se articulem, que pense o seu fazer. É o tal profissional, que não aparece. Porque o seu fazer, se bem feito, ajuda muito a escola a se articular, a se organizar, mas, é... digamos assim, o papel da ponta, o que parece não é o dele, é o do docente, a atuação dos alunos, mas, sempre tem alguém ajudando a articular com todo esse... e para além de... e compreendendo o papel da educação básica para as classes populares. Que é o papel da escola pública para as classes populares a importância fundamental da escola pública. $\mathrm{O}$ acesso à escola muda a vida das pessoas.

M: Com certeza.

Z: E por mais, que a gente tenha crítica a diversas questões educacionais... de práticas escolares, assim, não dá para negar, que... entrar na escola, permanecer nela, conseguir passar por toda a educação básica, acessar a universidade, isso transforma a vida das pessoas. Não é o suficiente para transformar a sociedade.

M: Hum hum.

Z: Mas, faz diferença.

M: Com certeza.

Z: No processo de transformação da sociedade, a sociedade precisa de alguém, que articule isso e eu acho, que as lutas da década de 80, de alguma maneira, isso estava muito em pauta. Estava muito em pauta. Dá muita saudade.

M: (Risos).

Z: Eu consigo ter saudade do Brizola.

M: (Risos).

Z: Porque a gente vê tanta tragédia hoje? Assim, a gente tinha enfrentamento com projeto de educação do Brizola, o sindicato teve esse enfrentamento, ele é a voz da categoria no enfrentamento com o projeto educacional do Darcy e do Brizola, mas, assim, é... que saudade de enfrentar aquele projeto porque hoje..

M: Existia um projeto.

Z: Existia um projeto.

M: (Risos).

Z: Existia um projeto.

M: Por pior que fosse, tinha projeto.

Z: Né? Então, hoje você tem... o saudosismo na...

M: (Risos) é porque a situação ficou tão ruim, eu te entendo plenamente... (risos).

Z: Que saudade de ter uma liderança como o Brizola (risos), para dar porrada, levando porrada de... ai que saudade.

M: Mas, é.

$\mathrm{Z}: \mathrm{O}$ que a gente tem hoje?

M: Era um embate real, né?

Z: Hum hum. Mas, isso estava em pauta.

M: Hum hum.

Z: Esse enfrentamento. Então, assim, porque na época da segunda gestão dele, onde claramente, ele resolve, que os CIEPS iam ter estagiários. Porque ele queria professor, sem... sem ranço. Então, assim, o sindicato é a voz de enfrentamento naquele momento. De... de transformação, o que é uma pena, que ele não tenha conseguido ver, a importância de engajar esses docentes nesse processo. Porque de alguma maneira, mesmo, que tenha uma marca populista, ele tinha uma visão...

M: Educativa.

Z: Educativa e tinha uma visão estratégica do papel da escola. Então, assim.

M: Hum hum. 
Z: É uma pena, que ele tenha jogado peso, queria ter condições mesmo de permanência de gestão ao ponto de transformar... mesmo, que ele fosse vencedor nessa história de transformar todas as escolas em CIEP. Não ia conseguir fazer isso, mas... ele poderia ter conciliado, mas, com saber, que esses docentes trazem do seu cotidiano porque... é... falta direção educacional nessa história, mas, assim, é... a categoria está mergulhada dentro das escolas, então, ela traz consigo um conhecimento, desse olhar, desses alunos. É um conhecimento, que sem direção, sem reflexão, serve pouco.

\section{M: Hum hum.}

Z: Mas, que... com direção e com provocações fundamentais, estratégicas possa a ajudar muito, o que não pode desconsiderar. Quanto de escola você tem na rede? É muita escola, como é que você transforma desconsiderando todo esse patamar de ação? Mesmo a escola precária, né? Você vê assim, digamos assim, é óbvio, que a gente vai aplaudir sempre o modelo de escola, como os CAPs e o Pedro II. São referências importantes, mas, são referências de um universo muito pequeno e de... condições de trabalho é... diferença tamanha.

\section{M: Exceção.}

Z: Aí você vai... eu trabalhei aqui, como eu falei, nos últimos 8 anos em abrigo, é... e a minha dissertação de mestrado vai trabalhar com essa questão do... se essa política social consegue ou não consegue de fato é... mudar a vida dos meninos em termos de escolaridade.

\section{M: Hum hum.}

Z: Só que uma das questões é colocar os meninos para estudar. E o quanto isso é difícil, mas, também assim, é reconhecido também, que é difícil para escola.

\section{M: Hum hum.}

Z: Como instituição, modelo de instituição que ela é e como ela funciona, dar conta desses diferentes indivíduos, mas, a gente tem algumas experiências específicas e interessantes nisso. Eu me lembro de um menino do abrigo, que... nossa, ele tinha... ele era contrariado, ele tinha uns surtos. É (risos), jogava pedra, não sei o que, era difícil a comunicação com ele, é... e, quando o abrigo, ele vai para o... ali para... Pilar.

\section{M: Hum hum.}

Z: A gente tem uma escola ali muito precária da rede municipal em termos físicos, condições, que é a Nossa Senhora do Pilar.

\section{M: Nossa Senhora do Pilar.}

Z: Eu não sei como ela está hoje, se ela foi reformada ou não, mas, assim, as condições eram precaríssimas, de chorar, de ver aquela... as condições daquela escola, mas, era a escola que os meninos tinham para frequentar e as outras do bairro muito similares. Mas, o quanto aquela escola, com toda a sua precariedade, com toda a sua dificuldade se engajou em contribuir com... para o Jonas permanecer na escola, o Jonas crescer, enquanto pessoa na escola. Assim, de conseguir comunicar a sua dificuldade, ao invés de ficar surtando e jogando pedra, pelo menos, diminuir os surtos dele (risos), a agressividade com os outros alunos ou com suas docentes. A conhecer uma... a conseguir conhecer o Jonas, que o abrigo conhecia, que a gente conhecia o lado ruim do Jonas, mas conhecia mil outras facetas, que ele tinha.

\section{M: Hum hum.}

Z: É... claro, como conhecia muito a história dele, conhecia e, assim, existem outras experiências em termos escolares. Então, assim, quando eu falo: "Da importância em direção a esse saber, a esse conhecimento dos professores, tem um pouco a ver com isso". Porque essa escola fez florescer a vida desse menino, entendeu? E não é nenhum Pedro II, nenhum CAP, mas ela fez..., não é porque foi a universidade, mas, ela faz diferença na trajetória dele e, se ela não consegue se instituir, enquanto instância educadora, comprometida com os sujeitos que ali estão, como ela se comprometeu com o Jonas, a gente deixa de cumprir o papel enquanto escola, enquanto escola que pode fazer diferença na vida das pessoas. E o que eu acho, assim, voltando para o SEPE, que a década de 80, ela é rica nessa reflexão das lutas. Isso é muito forte, está muito presente, eu até acho, que a gente conseguiu de uma maneira ampliar, talvez, em termos de organização, é... digamos, esse viés. A gente criou a direção educacional nos sindicatos. Em determinados momentos isso é mais forte, quer mais presente do que acho que fruto disso o... aqui em Caxias se conquistar o Cepemhed e o centro de... os museus de... é fruto dessa reflexão, é fruto de... tem sujeitos especiais 
aí nessa história, mas, é fruto dessa preocupação, que a gente tinha na organização sindical, que o contexto na década de 80 permitiu.

M: Hum hum.

Z: É... tem toda uma reflexão, quando os governos começam a colocar progressão continuada, ensino, a forma, como eles colocam... Então, assim, a gente tem uma parte da categoria, que estava ganha para ideia do ciclo da progressão continuada, mas, discorda totalmente, da forma como os governos implementam isso porque, na verdade, é muito mais implementado como uma política de resolver a questão dos índices de repetência, porque aí desaparecem, né? Do que preocupado em desenvolver a aprendizagem. A permanência, ela é fundamental para desenvolver a aprendizagem, mas, para isso é preciso transformar vários aspectos da escola. Então, eu acho, que... essas... todas essas coisas eu vi em pauta, entendeu? Era os enfrentamentos por melhores salários, mas, eram os enfrentamentos por essas transformações do fazer da escola, que deram frutos, eu não tenho dúvida, que deram frutos. Mas, acho que talvez algumas coisas pudessem ser ainda mais solidificadas, mais fortes. Então, eu não sei, qual é a... exatamente a sua questão, mas, assim, pensando no que é... no sindicato enquanto espaço formador, as lutas, como espaço formativo.

M: Hum hum.

Z: Eu posso dizer assim: que em termos de visão política, é... da importância do sindicato, é... não foi a luta em si, que me trouxe isso porque eu já chego na rede um pouco com esse compromisso, que a organização sindical era algo importante, mas, sem dúvida, ele amplia, ele consolida. Assim porque até antes de começar a militância é muito mais uma compreensão teórica, digamos assim, do que de fato constituída de história. E aí, ela vai se constituir de história e a gente vai ver diversas trajetórias ao longo do sindicato nesse sentido de crescimento, de compreensão e... então, eu acho, que... a luta, ela é fundamental nesse sentido ela forma mesmo você. Nunca é um aspecto só.

M: Hum hum.

Z: Mas, assim.

M: E...

Z: E aí tem, que compreender disputas, para além das disputas. Um pouco isso, não criticar as disputas, mas, é compreender, que está para além disso. A questão... você vai aprendendo, vai aprendendo, vai fazendo, vai aprendendo, vai refletindo, vai mudando.

M: Hum hum.

Z: Então...

M: Obrigada.

Z: Vê aí se você tem mais alguma questão aí, que queira perguntar, se quiser dar uma olhadinha

M: Eu acho, que você deu conta de tudo o que eu ia te perguntar. Muito bom! Obrigada, Zilda.

Z: Imagina. 